\title{
Application of Molecular Pathology Techniques to Understand Mechanisms of Disease in Smallmouth Bass
}

\author{
Heather Leigh Walsh \\ West Virginia University, heather.walsh@mail.wvu.edu
}

Follow this and additional works at: https://researchrepository.wvu.edu/etd

Part of the Environmental Indicators and Impact Assessment Commons, Environmental Monitoring

Commons, Fresh Water Studies Commons, and the Natural Resources and Conservation Commons

\section{Recommended Citation}

Walsh, Heather Leigh, "Application of Molecular Pathology Techniques to Understand Mechanisms of Disease in Smallmouth Bass" (2018). Graduate Theses, Dissertations, and Problem Reports. 3751. https://researchrepository.wvu.edu/etd/3751

This Dissertation is protected by copyright and/or related rights. It has been brought to you by the The Research Repository @ WVU with permission from the rights-holder(s). You are free to use this Dissertation in any way that is permitted by the copyright and related rights legislation that applies to your use. For other uses you must obtain permission from the rights-holder(s) directly, unless additional rights are indicated by a Creative Commons license in the record and/ or on the work itself. This Dissertation has been accepted for inclusion in WVU Graduate Theses, Dissertations, and Problem Reports collection by an authorized administrator of The Research Repository @ WVU.

For more information, please contact researchrepository@mail.wvu.edu. 


\title{
Application of Molecular Pathology Techniques to Understand Mechanisms of Disease in Smallmouth Bass
}

\author{
Heather Leigh Walsh \\ Dissertation submitted to the \\ Davis College of Agriculture, Natural Resources and Design \\ at West Virginia University \\ in partial fulfillment of the requirements \\ for the degree of \\ Doctor of Philosophy \\ in Forest Resources Science \\ Patricia Mazik, Ph.D., Committee Chair \\ Vicki S. Blazer, Ph.D. \\ Luke Iwanowicz, Ph.D. \\ Amy Welsh, Ph.D. \\ Kyle Hartman, Ph.D. \\ Wildlife and Fisheries Resources Program \\ Morgantown, West Virginia \\ 2018
}

Keywords: Chesapeake Bay drainage, smallmouth bass, young-of-the-year, risk factors, molecular pathology, histopathology, laser capture microdissection, fluorescence in situ hybridization, intersex, transcript abundance, non-model species, transcriptome, fish health, coinfections, parasites, land use, Next-Generation Sequencing, RNA-Sequencing, Nanostring nCounter® Technology

Copyright 2018 Heather Walsh 


\begin{abstract}
Application of Molecular Pathology Techniques to Understand Mechanisms of Disease in

Smallmouth Bass

Heather Leigh Walsh
\end{abstract}

In the Chesapeake Bay drainage, smallmouth bass Micropterus dolomieu are used as an indicator species of estrogenic contaminant exposure and have been implicated in fish kills and disease since 2005. In the Potomac River drainage, adult smallmouth bass have experienced mortality and disease and males have a high prevalence of intersex (testicular oocytes). Conversely, in the Susquehanna River drainage mortalities and disease of young-of-the-year smallmouth bass (YOY SMB) have occurred and resulted in a population shift to older and larger fish. The exact cause of these events remains unknown; however, factors such as poor water quality, contaminants, pathogens and parasites, increased temperatures, and nutrification have been assessed. In order to address this issue, the USGS Fish Health Branch, Leetown Science Center, and West Virginia Cooperative Fish and Wildlife Research Unit have ongoing assessment and monitoring projects throughout the Chesapeake Bay watershed. The use of routine histopathology has provided guidance for further research with molecular endpoints that may help explain the mechanisms involved in disease in smallmouth bass. The purpose of this dissertation research was to: 1.) Identify the prevalence of coinfections and risk factors of disease in YOY SMB; 2.) Use in situ hybridization to identify coinfections of bacteria with the myxozoan parasite Myxobolus inornatus in YOY smallmouth bass; 3.) Model liver helminths and coinfections of YOY SMB with land use at two spatial scales; 4.) Develop laser capture microdissection methods for nucleic acid extractions which could be used with smallmouth bass tissues; and 5.) Utilize Next-Generation Sequencing to develop a partial testes transcriptome to identify molecular markers that may help explain intersex development in male smallmouth bass. 


\section{DEDICATION}

I dedicate this work to my mother who has always supported me unconditionally and to my deceased father who strongly encouraged me to get my Ph.D. I also dedicate this work to my husband, Sean, and children, Fiona and Roland. 


\section{ACKNOWLEDGEMENTS}

I would like to thank the USGS Ecosystems and Environmental Health programs for funding this research. I thank my committee members Patricia Mazik, Vicki Blazer, Luke Iwanowicz, Amy Welsh, and Kyle Hartman for their rigorous questions and useful insight. I would like to thank the many people who have helped in the laboratory and in the field including

Kathy Spring, Adam Sperry, Darlene Bowling, Pam Whittington, Ryan Braham, Cynthia Adams, Cheyenne Simpson, Megan Keplar, and Kelsey Young. Finally, I would like to give a huge thanks to state agencies including the West Virginia Division of Natural Resources, Pennsylvania Department of Environmental Protection, Pennsylvania Fish and Boat Commission, and the Virginia Department of Game and Inland Fisheries for collecting the fish used in my research. 


\section{FOREWORD}

This dissertation consists of five research chapters, with some formatted as manuscripts for scientific journals. Chapter two has been published in the Journal of Aquatic Animal Health with the following co-authors: Vicki S. Blazer, Geoffrey D. Smith, Michael Lookenbill, David A. Alvarez, and Kelly L. Smalling. Chapter three has not been formatted for journal publication. Chapter four has been written in the format of Journal of Fish Diseases. Chapter five has been written in the format of PLoS ONE. Chapter six has been written in the format of BMC Genomics. 


\section{Table of Contents}

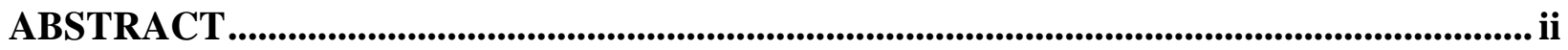

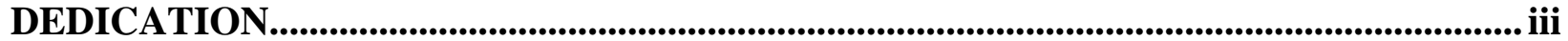

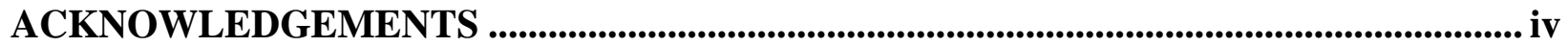

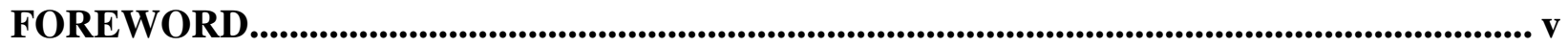

Chapter One: Introduction and Literature Review ............................................................................. 1

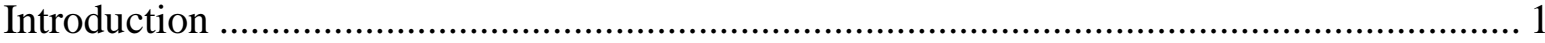

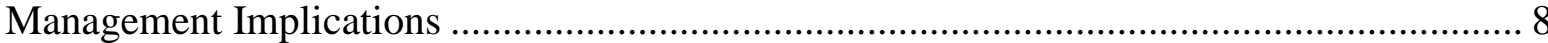

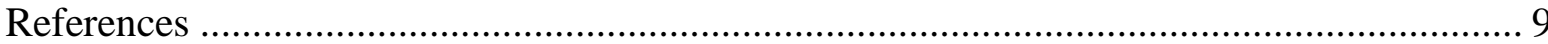

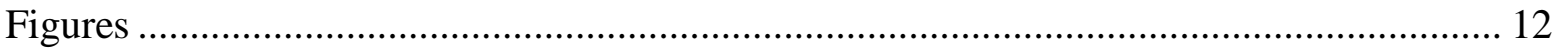

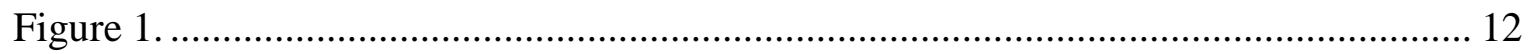

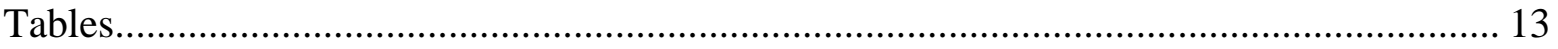

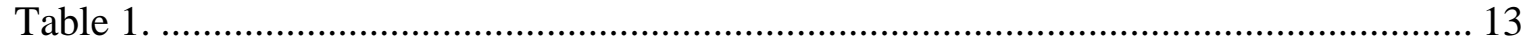

Chapter Two: Risk Factors Associated with Age-0 Smallmouth Bass Mortality in the Susquehanna River Basin, Pennsylvania, USA ............................................................................ 15

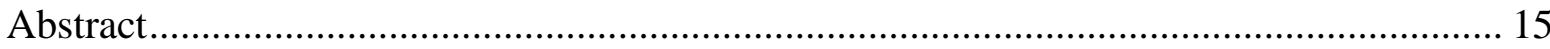

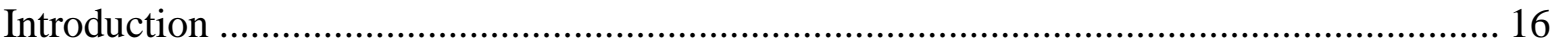

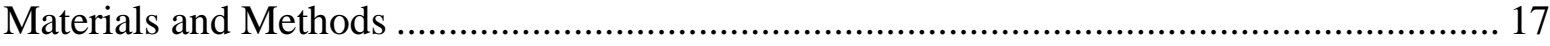

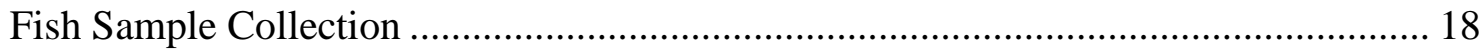

Microscopic Pathology ............................................................................................. 19

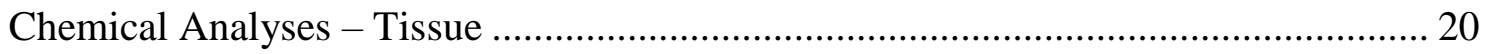

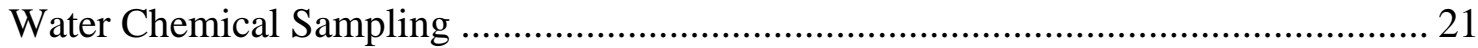

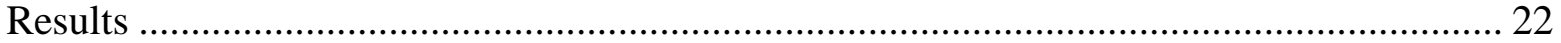

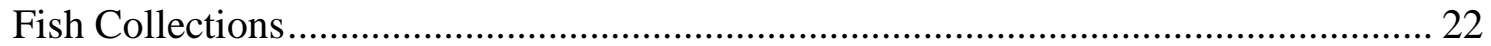

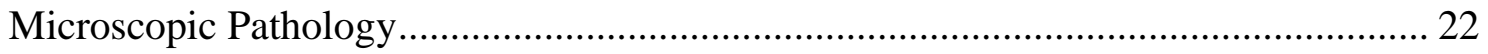

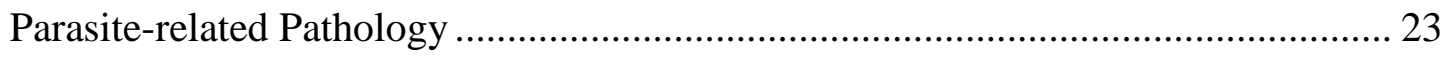

Bacteria-related Pathology .................................................................................. 24

Pathology of Unidentified Etiology ...................................................................... 25

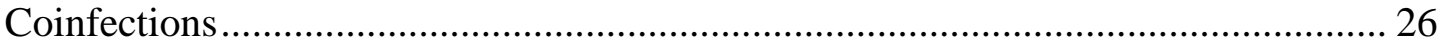

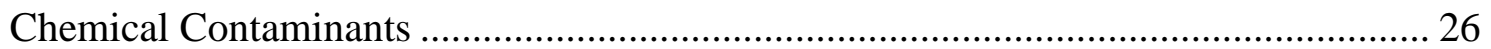

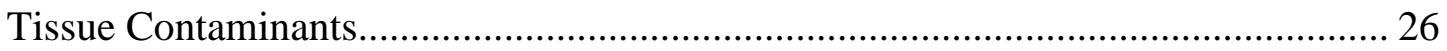

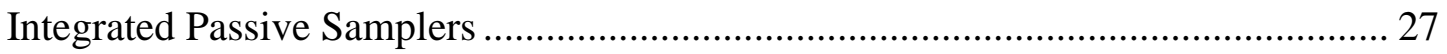




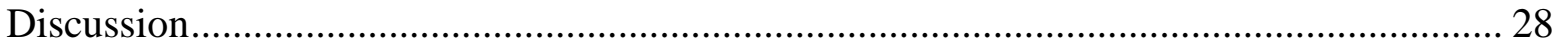

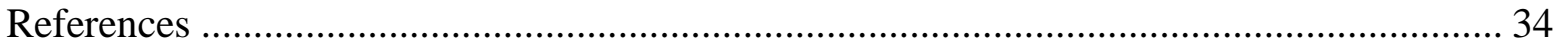

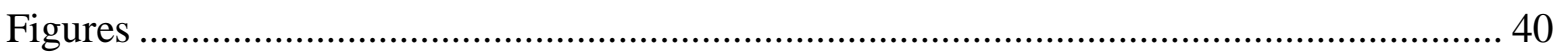

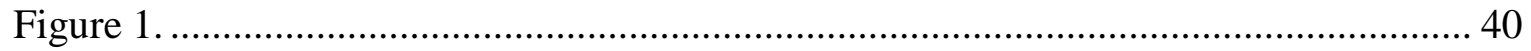

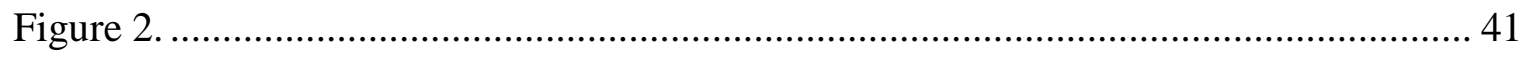

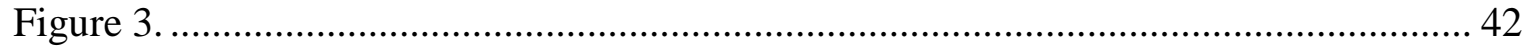

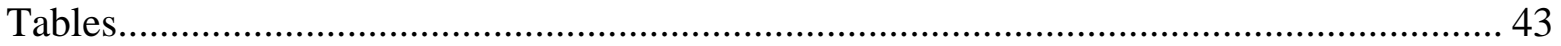

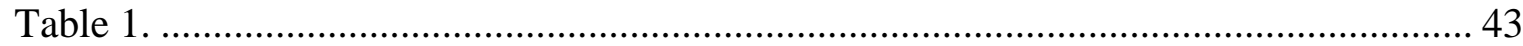

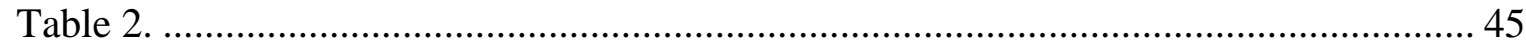

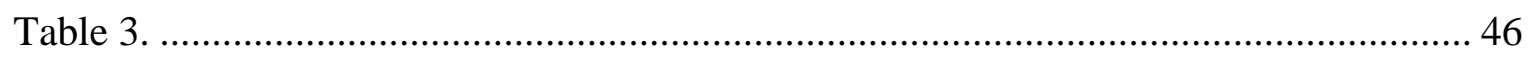

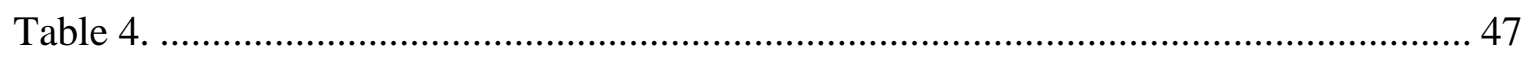

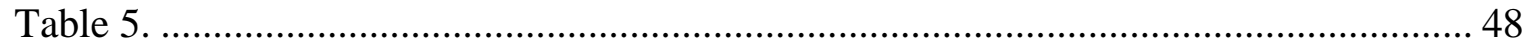

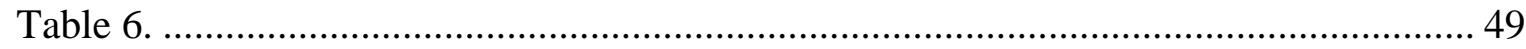

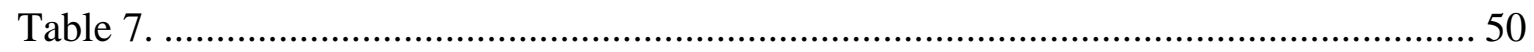

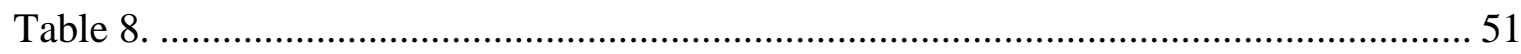

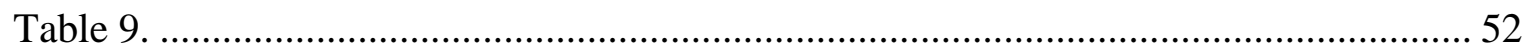

Supplementary Table 1 ............................................................................................ 53

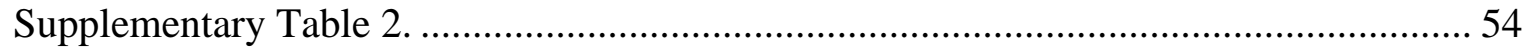

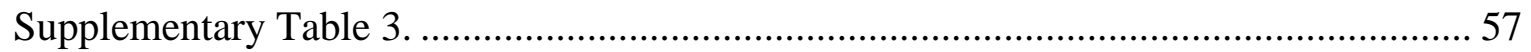

Chapter Three: The Use of Fluorescence In Situ Hybridization (FISH) for Identification of Coinfections in Young-of-the-Year Smallmouth Bass from the Susquehanna River Drainage, Pennsylvania, USA .......................................................................................................... 58

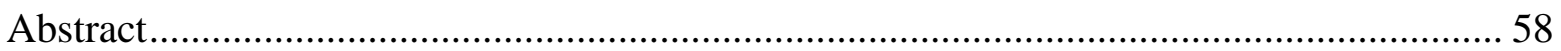

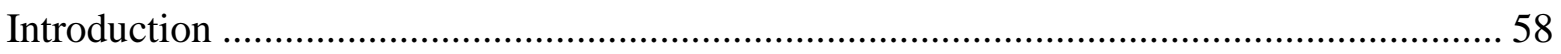

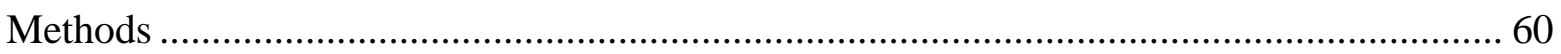

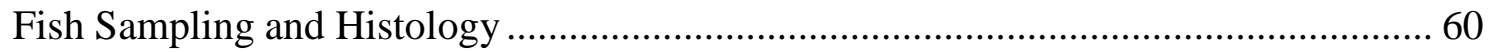

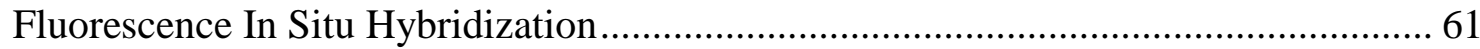

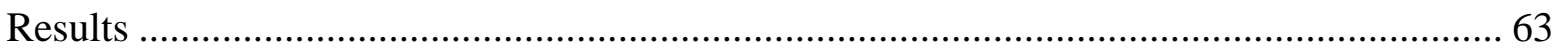

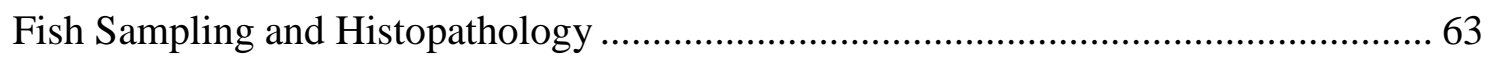

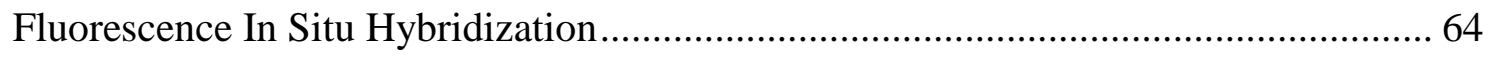

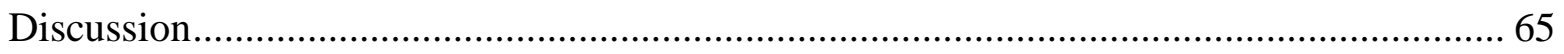

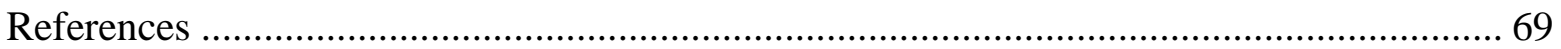

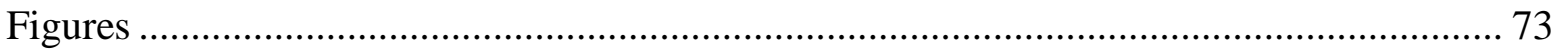




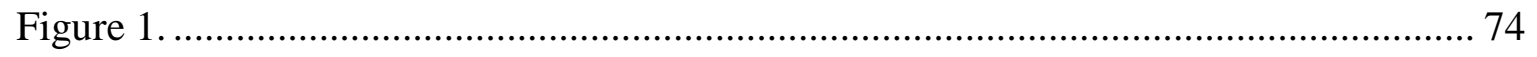

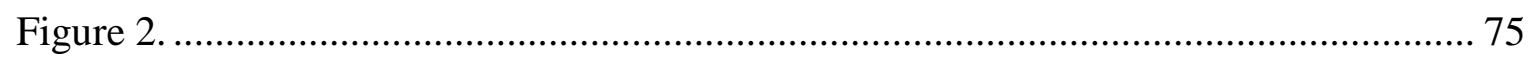

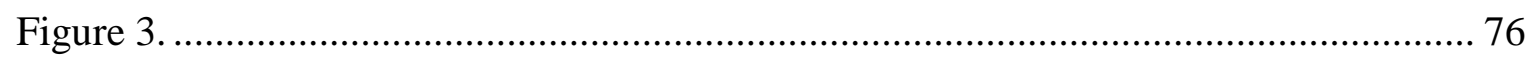

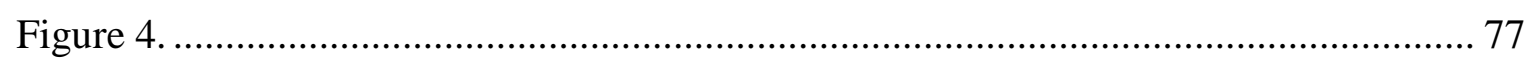

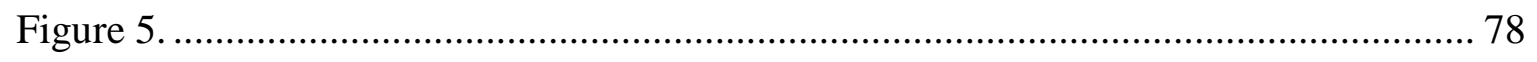

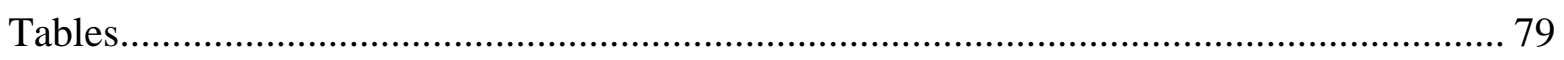

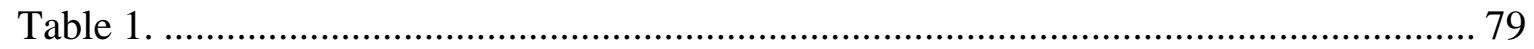

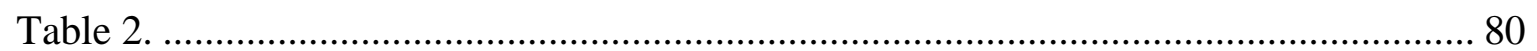

Chapter Four: Associations of Liver Helminths and Coinfections with Landuse in Youngof-the-Year Smallmouth Bass in the Chesapeake Bay Drainage, USA...................................... 81

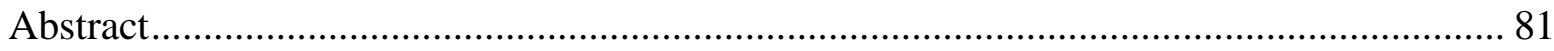

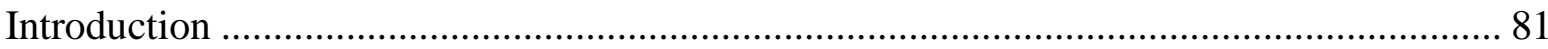

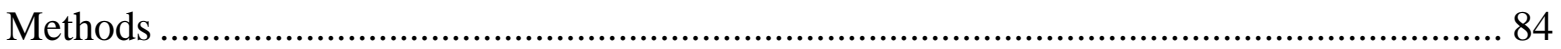

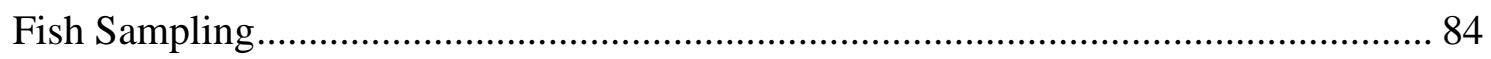

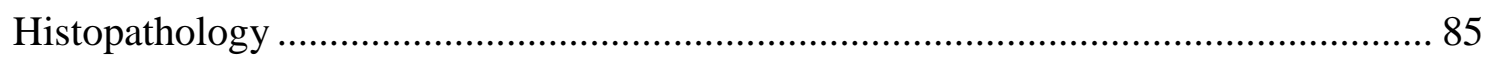

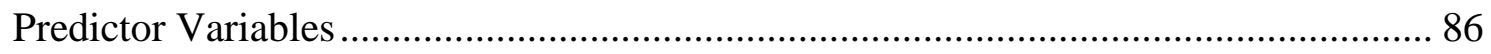

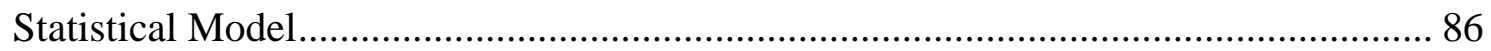

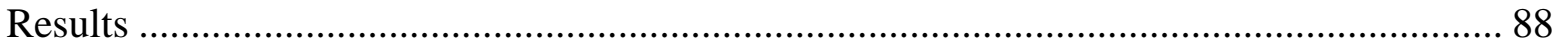

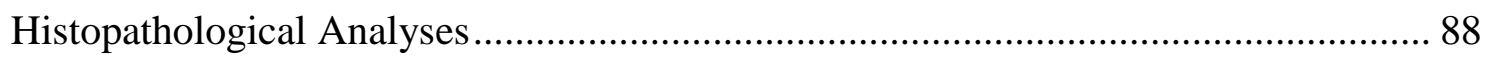

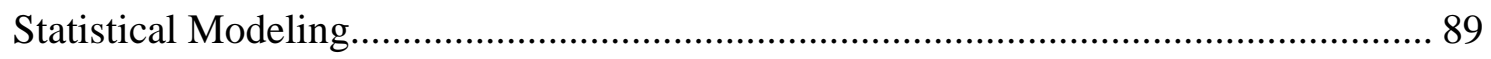

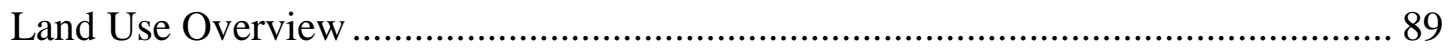

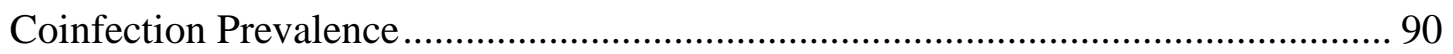

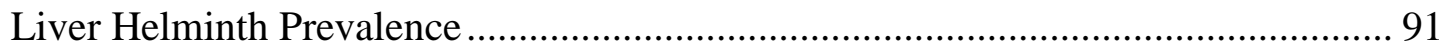

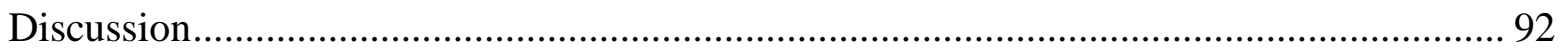

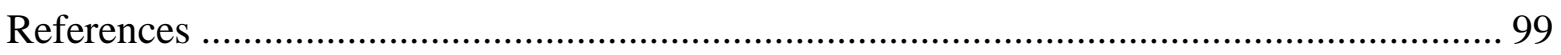

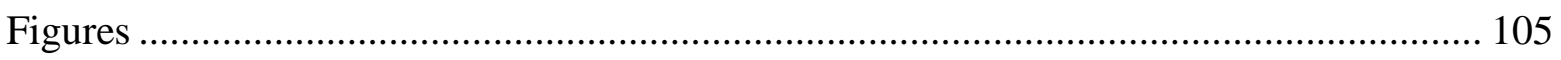

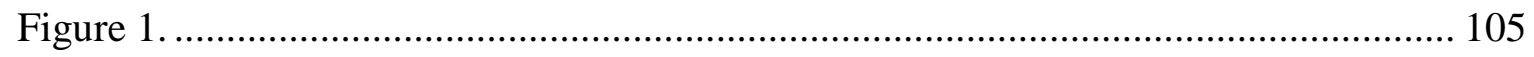

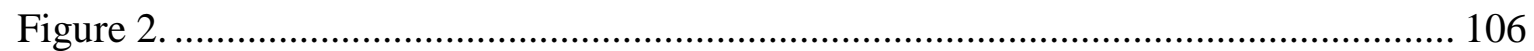

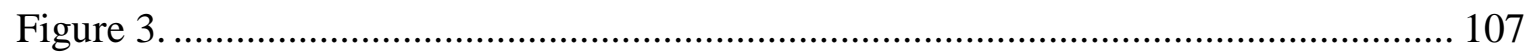

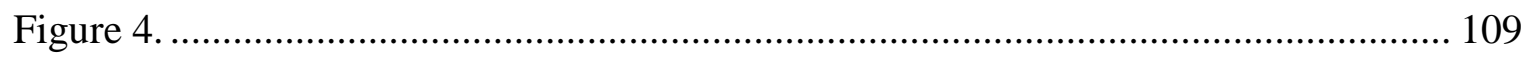

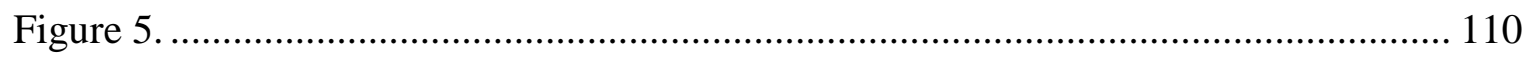

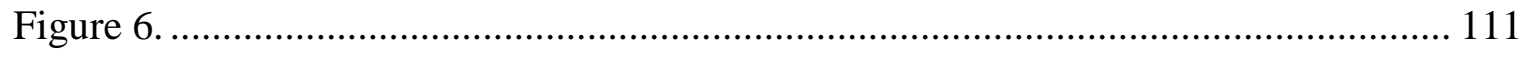

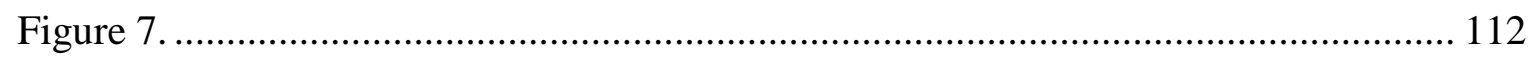




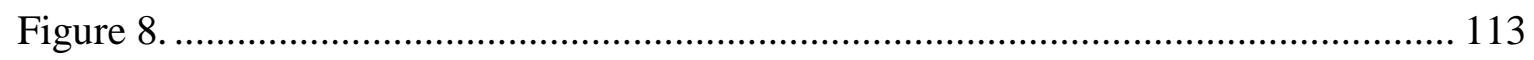

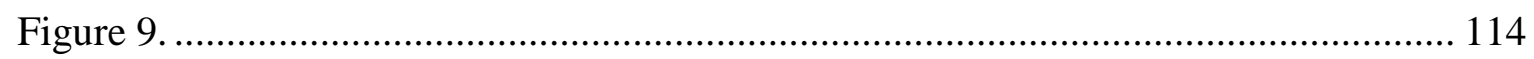

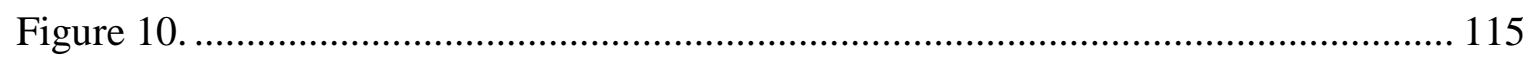

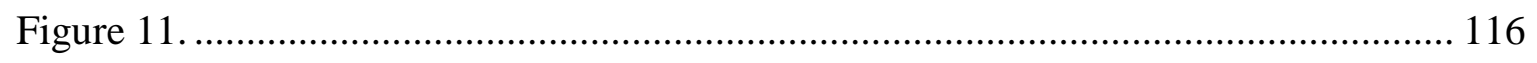

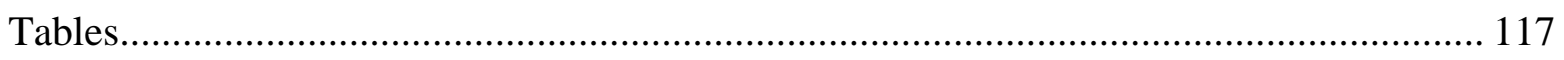

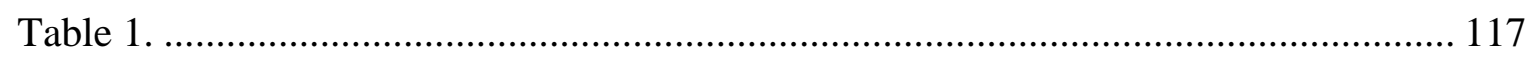

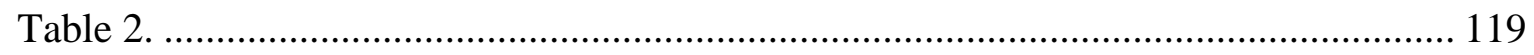

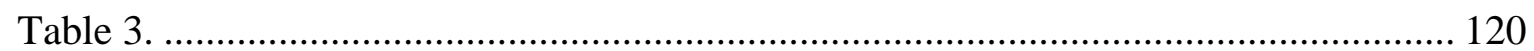

Chapter Five: The Effects of Tissue Fixation on Nucleic Acids from Laser Capture Microdissection Tissue Samples of a Teleost..................................................................................... 121

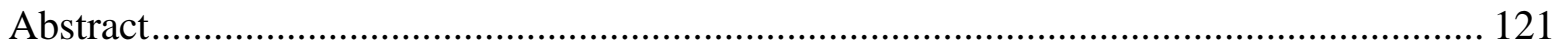

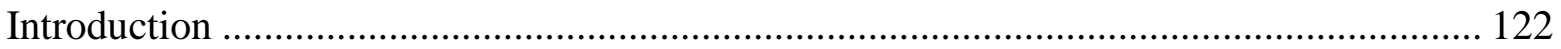

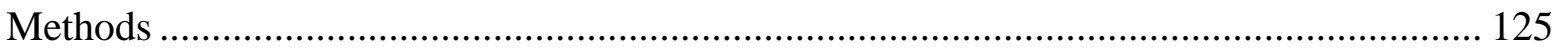

Smallmouth Bass Sample Collection ................................................................... 125

Histological Preparation and Laser Capture Microdissection....................................... 125

Nucleic Acid Extraction and Quantification ................................................................ 127

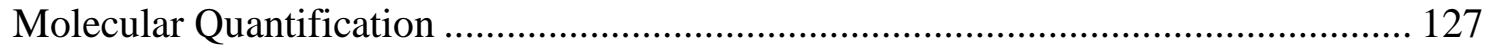

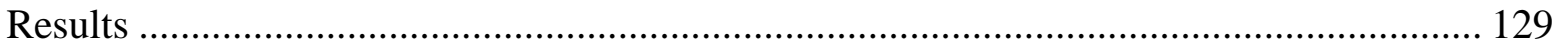

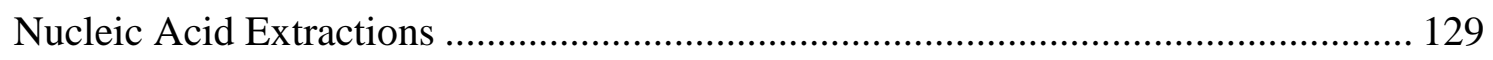

Molecular Quantification ...................................................................................... 131

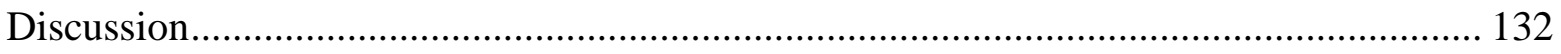

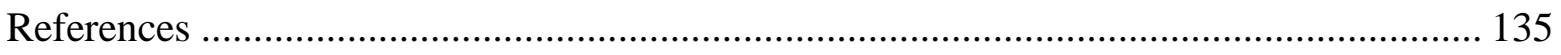

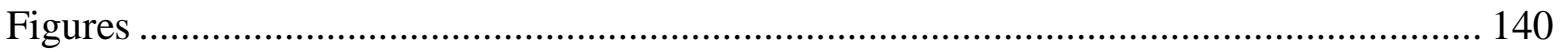

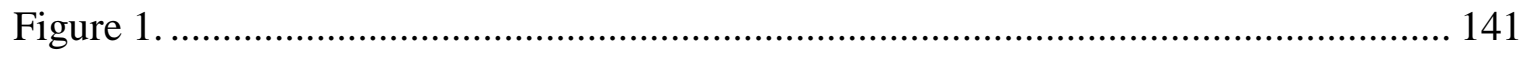

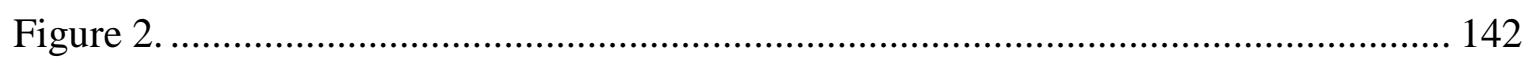

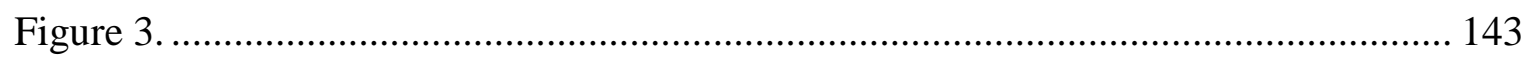

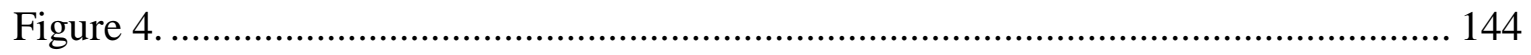

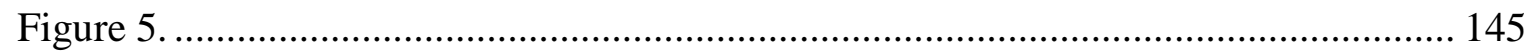

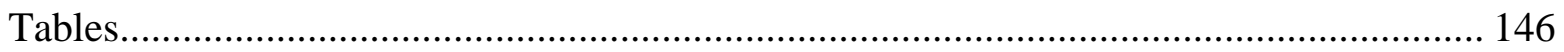

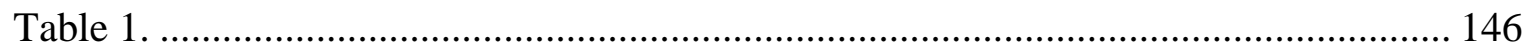

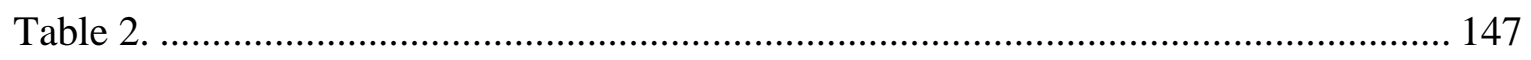

Chapter Six: Testes Transcriptome Development and Alterations in Transcript Abundance in Intersex Smallmouth Bass (Micropterus dolomieu) .................................................................. 149 


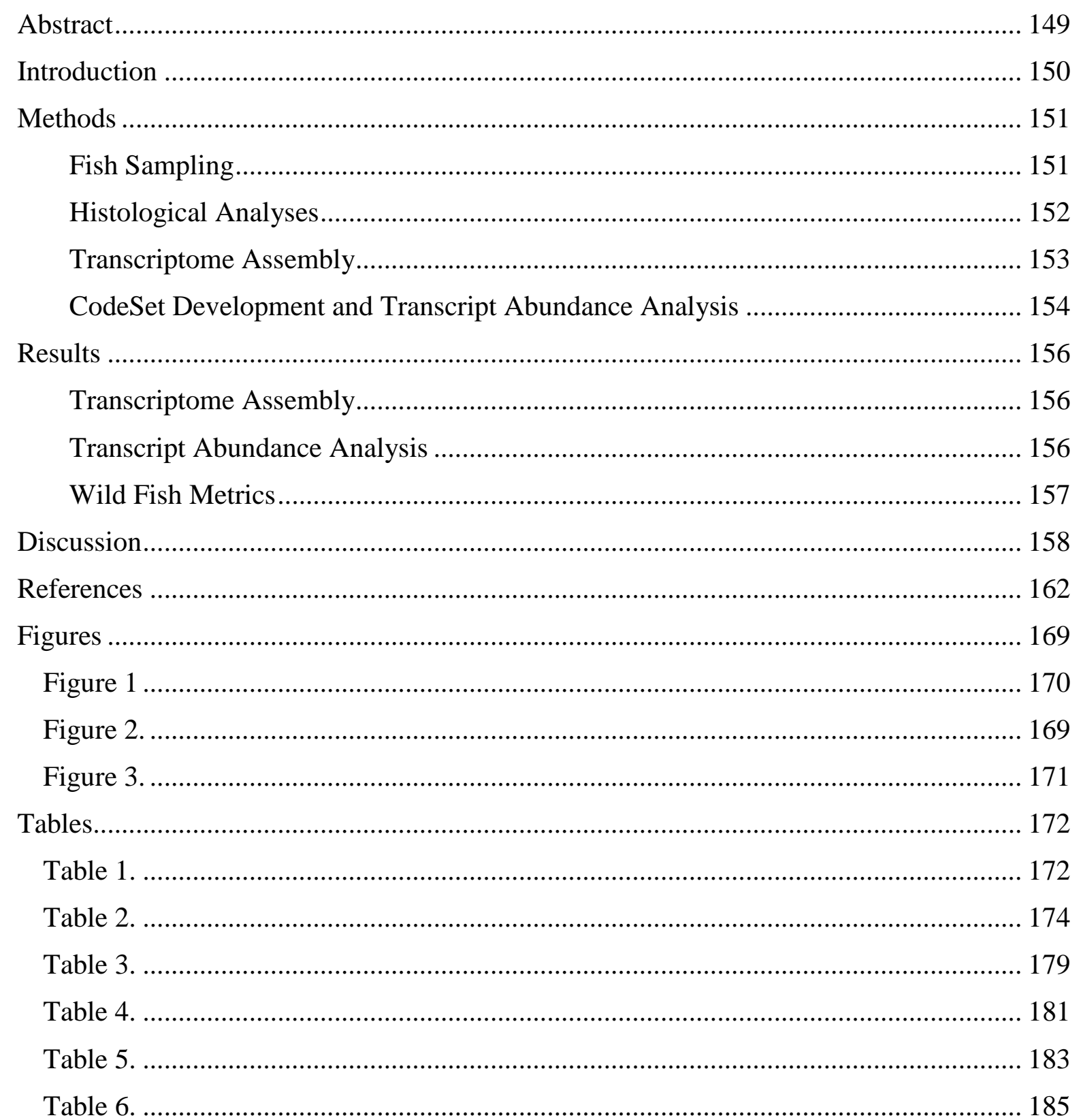




\section{Chapter One: Introduction and Literature Review}

\section{Introduction}

Fish health is increasingly used as an indicator of ecosystem health. The complex interactions of pathogens/parasites, environmental stressors (contaminants, climate, water quality, and hydrology) and disease resistance of the host often make it difficult to identify causes and underlying mechanisms for specific disease issues. Adverse effects of exposure to contaminants, such as intersex (testicular oocytes), skin and liver tumors and increased infectious disease prevalence can be monitored. However, to restore the health of fish populations, the underlying causes and/or contributing factors to these adverse effects need to be understood.

The USGS Fish Health Branch, Leetown Science Center and West Virginia Cooperative Fish and Wildlife Research Unit have ongoing assessment and monitoring projects throughout the Chesapeake Bay watershed. A number of fish health issues have been identified in these studies which have not, to date, been fully explained and hence there is a lack of information necessary for restoration and/or management of the contributing factors. Such health issues have included fish mortalities, skin lesions, parasites/pathogens, and intersex. Efforts to determine the cause of the fish kills and lesions of adult smallmouth bass in the Potomac River drainage first began in 2003 and fish health assessments are still ongoing. The cause of the fish kills still remains unknown, although it is likely a cumulative problem involving multiple factors such as poor water quality, chemicals of emerging concern (CECs), agricultural and industrial runoff, parasites, spawning stress, and immunosuppression. One purpose of this study was to develop molecular pathology techniques to address specific, unanswered questions on the disease observed in smallmouth bass from sites that had, or continue to have, mortality events and disease outbreaks. 
In a study by Blazer et al. (2007) all of the sites sampled in the South Branch of the Potomac River had males which exhibited various prevalence and severity levels of testicular oocytes. Testicular oocytes are induced with exposure to estrogenic compounds and intersex fish often have increased concentrations of estrogenic sex steroid hormones and the egg yolk precursor, vitellogenin (Jobling et al., 2006; Kidd et al., 2007). In male smallmouth bass from the South Branch Potomac River, agricultural runoff is likely the largest contributing factor of intersex (Blazer et al., 2007). It also remains unknown when male smallmouth bass are most sensitive for developing testicular oocytes. The second purpose of this study was to develop a partial transcriptome and molecular biomarkers of intersex in smallmouth bass.

Similar to the disease outbreaks experienced by adult smallmouth bass in the Potomac River drainage, young-of-the-year smallmouth bass (YOY SMB) in the Susquehanna River drainage began to experience mortalities and skin lesions in the summer of 2005. Possible contributing factors include high water temperatures, low dissolved oxygen, parasites, pathogens, immunosuppression, and contaminants. Some of the fish were observed with small to large lesions on the skin surface and in some instances the lesions penetrated into the muscle. Bacterial swabs of the lesions were taken in 2009 from multiple sites and Flavobacterium columnare, Aeromonas veronii bv. sobria, A. hydrophila, Pseudomonas sp., and Plesiomonas shiggeloides were isolated (Starliper et al. 2013). Parasites observed in YOY smallmouth bass included trematodes in the muscle and liver, cestodes in the gut, and the myxozoan Myxobolus inornatus. Myxobolus inornatus was first identified in YOY largemouth bass from a Montana fish hatchery and was re-described from YOY smallmouth bass from the Susquehanna River (Fish 1939; Walsh et al. 2012). The plasmodia infect the connective tissue of the muscle ventral to the dorsal fin and along the caudal peduncle but have also been observed histologically along 
the esophagus and in areas deep within the muscle connective tissue. Occasionally, shallow infections of $M$. inornatus just below the epidermis can cause perforations of the skin and may provide areas of invasion for opportunistic bacteria. In addition to parasite infections, a systemic infection has been observed in multiple tissues, including the liver, spleen, mesentery, around the spinal cord, and in the eye. In chapter two, the prevalence of coinfections of parasites, skin lesions, and systemic infections will be determined and associated with contaminants found in fish tissues and in the water. It is important to consider the effects of coinfections and contaminants on the health of YOY smallmouth bass primarily since both factors can affect immune function and disease resistance.

In fish health assessments, histopathology (McHugh et al. 2011; Saraiva et al. 2015; Schlacher et al. 2007; van Dyk et al. 2009) and molecular biomarkers (Livingstone 1993; Scholz and Mayer 2008; Valavanidis et al. 2006) have been widely used. In an effort to better understand the effects of disease on smallmouth bass in the Potomac and Susquehanna River drainages, histopathology, in situ hybridization (ISH), laser capture microdissection (LCM), and Next-Generation Sequencing will be used. There are numerous benefits of incorporating multiple techniques to understand fish health. As part of the adverse outcome pathway, the connection between a molecular initiating event and an adverse outcome at the population level is examined (Ankley et al. 2010). Contaminants, or xenobiotics, cause changes to biomolecules which causes a cascade of changes within individuals, such as tumor formations or intersex. When these changes afflict enough individuals, it can affect the entire population. Incorporation of multiple techniques to observe changes to the cells, tissues, and biomolecules coupled with contaminant data at sites within the Potomac and Susquehanna River drainages provides a deeper insight into the cause of the fish kills and disease occurrences. 
With routine histopathology, only observations on pathological changes to tissues and/or general identification of parasites can be made. For example, in most studies with wild fishes, field collection involves removing pieces of organs that are preserved, generally in a formalinbased fixative for histopathological analyses and other small pieces preserved in RNAlater ${ }^{\circledR}$ for gene expression. While this approach has and continues to provide a great deal of mechanistic information, there are some major drawbacks. For instance, the liver of fishes contains numerous tissues - hepatocytes, bile ducts and hepatopancreatic tissue. Additionally, lesions such as bile duct proliferation, altered cell foci and most hepatic tumors are not grossly visible. Therefore, when pieces of liver are removed and extracted for gene expression studies, it is unknown exactly what tissue and/or abnormalities are included in that piece of tissue. Techniques such as LCM and ISH have helped to overcome this issue.

Laser capture microdissection is the use of a microscope equipped with a laser which can be used to target specific cells from a heterogeneous population of cells from a tissue section (Emmert-Buck et al. 1996). Single cells that are malignant, neoplastic, abnormal, or parasites can be microdissected while the surrounding normal tissue remains on the slide. The benefit is being able to directly analyze the biomolecules from specific populations of cells which is extremely useful in gene expression studies, transcriptome development, or parasite identification. When conducting downstream analyses of nucleic acids from these tissues, most studies use snap-frozen tissue since formalin fixation rapidly degrades and cross-links nucleic acids (Gouveia et al. 2016). However, obtaining snap-frozen tissue when sampling wild fish is not always feasible; therefore, formalin fixed tissue may be the only option. Other factors have also been shown to be important for the downstream extraction of nucleic acids from FFPE tissue, including fixative type and the duration of fixation. To optimize these factors for our 
laboratory, chapter three will address the effects of fixation time and/or fixative type on the downstream recovery of DNA and RNA and whether these samples are useful for gene quantification methods such as qPCR and the Nanostring nCounter®.

In situ hybridization was first described in 1969 and has since become an invaluable tool for examining gene expression in tissues (Wilcox 2000). In situ hybridization uses a chromogenic or fluorescently labeled probe to anneal to complementary DNA or RNA in histological tissue sections which can be visualized microscopically. Location of the nucleic acids can be observed and provides information on the types of cells which transcribe a particular gene or in other instances, which cells are infected with a parasite or virus. In chapter 3, ISH will be used with YOY smallmouth bass tissue to identify whether areas of inflammation harbor M. inornatus infections or whether coinfections of M. inornatus and pathogenic bacteria are prevalent. In some instances, observations with routine histology revealed areas in the fish that resembled $M$. inornatus infections but the parasite was not directly observed. The use of ISH for these occurrences can provide more accurate data for determining the prevalence of this parasite. Additionally, there has been some concern that shallow M. inornatus infections provide areas for opportunistic bacteria to invade. In situ hybridization will be used to determine prevalence of these types of coinfections. Chapter four will also attempt to determine the pathogen which causes the systemic infections in the YOY smallmouth bass with the use of LCM and Next-generation sequencing. Areas within tissues of YOY smallmouth bass which display symptoms of systemic infections will be cut out with LCM, extracted for RNA, and subsequently sequenced with an Illumina MiSeq.

As previously mentioned, many male adult smallmouth bass sampled from the Potomac and Susquehanna River drainages have been observed to have intersex. Intersex has been widely 
studied in fish (Abdel-moneim et al. 2015) and is used as a biomarker of exposure to endocrine disrupting chemicals (EDCs) released in wastewater treatment plant effluent (Tetreault et al. 2011), agricultural runoff (Blazer et al. 2012), and industrial effluent (Fentress et al. 2006). Reproductive effects such as reduced sperm motility and abundance have been observed in smallmouth bass (Blazer et al. 2012); however, population-level effects and time of induction remain unknown. Additionally, smallmouth bass have been the most commonly reported species of fish with intersex and it occurs more often in bass which inhabit waters with agricultural and industrial landuse (Abdel-moneim et al. 2015).

Histology is most commonly used to identify the presence of intersex. Although this method is widely accepted (Depiereux et al. 2014; Feswick et al. 2016; Kobayashi et al. 2017), the drawback remains that intersex can be missed since the entire testes is not examined, except for only a subset of cross-sections. Molecular techniques overcome this issue by identifying the presence of intersex with specific biomarker genes (Kishi et al. 2006; Martinović-Weigelt et al. 2011; Mehinto et al. 2012; Valencia et al. 2017; Zhao et al. 2012). For non-model fish, such as smallmouth bass, this type of sequence data remains scarce or unavailable. Chapter five will describe the development of a partial transcriptome of the testes and intersex biomarker genes. A differential gene expression analysis of these biomarker genes in male smallmouth bass from the Potomac and Susquehanna River drainages will be done and correlations with contaminants sampled at selected sites will be analyzed.

The selection of intersex biomarker genes in this study was based on genes found in the literature that were associated with intersex or reproduction (Bahamonde et al. 2015; Baron et al. 2005b; Deloffre et al. 2012; Depiereux et al. 2014; Garacia-Reyero et al. 2009; Kishi et al. 2006; Zhao and $\mathrm{Hu} 2012$ ) and genes that were found to be differentially regulated between intersex and 
non-intersex fish used in this study. In addition to these genes, housekeeping genes were included to account for transcriptional variation that occurs between fish. Good housekeeping genes are relatively stable between individuals and environmental factors. Housekeeping genes selected for this study include 40S Ribosomal Protein S18, Eukaryotic Translation Initiation Factor 3D, beta actin, Ribosomal Protein L8, 40S Ribosomal Protein S12, and Eukaryotic Translation Elongation Factor 1 alpha. These genes were examined for stability and the three best housekeeping genes were used in downstream differential gene expression analyses.

Multiple female reproductive genes were selected to include in the Nanostring nCounter® Custom CodeSet. These genes included 42Sp43, homeobox protein NOBOX, nanos, zygote arrest protein 1 , zona pellucida 3 , zona pellucida $3 \mathrm{iX1}$, zona pellucida 4 , zona pellucida AX, and aromatase. As constituents of oocytes or female sex differentiation these genes should only be found in female fish; however, they have been found to be upregulated in male fish with intersex (Bahamonde et al. 2015; Depiereux et al. 2014; Zhao et al. 2012). Similarly, male reproductive genes that have been shown to be downregulated in male intersex fish (Bahamonde et al. 2015; Baron et al. 2005; Depiereux et al. 2014) were also selected. These genes include doublesex-and mab-3-related transcription factor genes 2 and 3, follistatin-like 3, nuclear receptor subfamily 0 group B member 1, sperm flagellar genes, sperm surface protein 17, and sex-determining region Y-box 9b. Two additional genes were included which were found to group with the zona pellucida genes but remained uncharacterized when blasted in NCBI. Other genes included in the Custom CodeSet were genes that are involved in steroidogenesis, fertility, and gonadal development. These included cytochrome P450 11B, dehydrogenase reductase SDR family member 11, gonadotropin releasing hormone receptor, inhibin alpha, inhibin beta $b$, insulin like growth factor binding protein 1,2A, 3, and 5, luteinizing hormone receptor, relaxin 
receptor 2, sex determining region Y-Box 7, synaptonemal complex protein 1, Wnt family member 5B, 17-B hydroxysteroid dehydrogenase, and 3-B hydroxysteroid dehydrogenase. These genes were differentially regulated in intersex fish found in other studies (Depiereux et al. 2014; Garcia-Reyero et al. 2009) or differentially regulated in male intersex smallmouth bass from this study.

\section{Management Implications}

Development of a comprehensive approach to understand the health of smallmouth bass in the Chesapeake Bay drainage has utility that can be applied to fish health surveys of other species in other water bodies. The adverse outcome pathways approach allows for the researcher to answer multiple types of questions starting from molecular changes to an organism, to microscopic observations at the cellular and tissue level, to observations of changes to the organs. These components help explain observed effects at the individual level and whether population level effects occur. By conducting these types of assessments on a yearly basis, we can identify normality at individual sites and can more accurately characterize what is abnormal. Future work can also be developed to integrate these findings with land use and geospatial analyses, ongoing contaminant assessments, and population trend data to provide a comprehensive adverse effects approach to understanding fish health. This provides stakeholders with the knowledge on how to best implement managerial practices to improve the habitat for healthier smallmouth bass populations in the Potomac and Susquehanna River drainages. 


\section{References}

Abdel-moneim, A., D.P. Coulter, C.T. Mahapatra, and M.S. Sepúlveda. 2015. Intersex in fishes and amphibians: population implications, prevalence, mechanisms, and molecular biomarkers. Journal of Applied Toxicology 35: 1228-1240.

Ankley, G.T., R.S. Bennett, R.J. Erickson, D.J. Hoff, M.W. Hornung, R.D. Johnson, D.R. Mount, J.W. Nichols, C.L. Russom, P.K. Schmieder, J.A. Serrrano, J.E. Tietge, and D.L. Villeneuve. 2010. Adverse outcome pathways: A conceptual framework to support ecotoxicology research and risk assessment. Environmental Toxicology and Chemistry 29: $730-741$.

Bahamonde, P.A., M.E. McMaster, M.R. Servos, C.J. Martyniuk, and K.R. Munkittrick. 2015. Molecular pathways associated with the intersex condition in rainbow darter (Etheostoma caeruleum) following exposures to municipal wastewater in the Grand River basin, ON, Canada. Part B. Aquatic Toxicology 159: 302-316.

Baron, D., R. Houlgatte, A. Fostier, and Y. Guiguen. 2005. Large-scale temporal gene expression profiling during global differentiation and early gametogenesis in rainbow trout. Biology of Reproduction 73: 959-966.

Blazer, V.S., L.R. Iwanowicz, H. Henderson, P.M. Mazik, J.A. Jenkins, D.A. Alvarez, and J.A. Young. 2012. Reproductive endocrine disruption in smallmouth bass (Micropterus dolomieu) in the Potomac River basin: spatial and temporal comparisons of biological effects. Environmental Monitoring and Assessment 184: 4309-4334.

Blazer, V.S., L.R. Iwanowicz, D.D. Iwanowicz, D.R. Smith, J.A. Young, J.D. Hedrick, and S.W. Foster. 2007. Intersex (testicular oocytes) in smallmouth bass from the Potomac River and selected nearby drainages. Journal of Aquatic Animal Health 19: 242-253.

Deloffre, L.A.M., A. Andrade, A.I. Filipe, and A.V.M. Canario. 2012. Reference genes to quantify gene expression during oogenesis in a teleost fish. Gene 506:69-75.

Depiereux, S., M. Liagre, L. Danis, B. De Meulder, E. Depiereux, H. Segner, and P. Kestemont. 2014. Intersex occurrence in rainbow trout (Oncorhynchus mykiss) male fry chronically exposed to ethynylestradiol. PLOS One 9: e98531.

Emmert-Buck, M.R., R.F. Bonner, P.D. Smith, R.F. Chuaqui, Z. Zhuang, S.R. Goldstein, R.A. Weiss, and L.A. Liotta. 1996. Laser capture microdissection. Science 274: 998-1001.

Fentress, J.A., S.L. Steele, H.L. Bart, Jr., and A.O. Cheek. 2006. Reproductive disruption in wild longear sunfish (Lepomis megalotis) exposed to kraft mill effluent. Environmental Health Perspectives 114: 40-45.

Feswick, A., J.R. Loughery, M.A. Isaacs, K.R. Munkittrick, and C.J. Martyniuk. 2016. Molecular initiating events of the intersex phenotype: low-dose exposure to $17 \alpha$ - 
ethinylestradiol rapidly regulates molecular networks associated with gonad differentiation in the adult fathead minnow testis. Aquatic Toxicology 181: 45-56.

Fish, F.F. 1939. Notes on Myxobolus inornatus n. sp., a myxosporidian parasitic in the black bass (Huro floridana, Le Sueur). Transactions of the American Fisheries Society 68: 173-177.

Garcia-Reyero, K.J. Kroll, L. Liu, E.F. Orlando, K.H. Wantanabe, M.S. Sepúlveda, D.L. Villeneuve, E.J. Perkins, G.T. Ankley, and N.D. Denslow. 2009. Gene expression responses in male fathead minnows exposed to binary mixtures of an estrogen and antiestrogen. BMC Genomics 10: 308-325.

Gouveia GR, Ferreira SC, Siqueira SAC, Pereira J. Nucleic acids extraction from formalin-fixed and paraffin-embedded tissues. In: M.L. Larramendy and S. Solenski. Nucleic acids from basic aspects to laboratory tools. InTech, 2016. pp. 27-36.

Kidd, K.A., P.J. Blanchfield, K.H. Mills, V.P. Palace, R.E. Evans, J.M. Lazorchak, and R.W. Flick. 2007. Collapse of a fish population after exposure to a synthetic estrogen. PNAS 104: 8897-8901.

Kishi, K., E. Kitagawa, N. Onikura, A. Nakamura, and H. Iwahashi. 2006. Expression analysis of sex-specific and $17 \beta$-estradiol-responsive genes in the Japanese medaka, Oryzias latipes, using oligonucleotide microarrays. Genomics 88: 241-251.

Kobayashi, T., A. Chiba, T. Sato, T. Myosho, J. Yamamoto, T. Okamura, Y. Onishi, M. Sakaizumi, S. Hamaguchi, T. Iguchi, and Y. Horie. 2017. Estrogen alters gonadal somaderived factor $(G s d f) / F o x l 2$ expression levels in the testes associated with testis-ova differentiation in adult medaka, Oryzias latipes. Aquatic Toxicology 191: 209-218.

Livingstone, D. R. 1993. Biotechnology and pollution monitoring: Use of molecular biomarkers in the aquatic environment. Journal of Chemical Technology and Biotechnology, 57: 195-211.

Martinović-Weigelt, D., R-L. Wang, D.L. Villeneuve, D.C. Bencic, J. Lazorchak, and G.T. Ankley. 2011. Gene expression profiling of the androgen receptor antagonists flutamid and vinclozolin in zebrafish (Danio rerio) gonads. Aquatic Toxicology 101: 447-458.

McHugh, K.J., N.J. Smit, J.H.J. Van Vuren, J.C. Van Dyk, L. Bervoets, A. Covaci, and V. Wepener. 2011. A histology-based fish health assessment of the tigerfish, Hydrocynus vittatus from a DDT-affected area. Physics and Chemistry of the Earth 36: 895-904.

Mehinto, A.C., C.J. Martyniuk, D.J. Spade, and N.D. Denslow. 2012. Applications of nextgeneration sequencing in fish ecotoxicogenomics. Frontiers in Genetics 3: 1-10.

Saraiva, A., J. Costa, J. Serrão, C. Cruz, and J.C. Eiras. 2015. A histology-based fish health assessment of farmed seabass (Dientrarchus labrax L.). Aquaculture 448: 375-381. 
Schlacher, T.A., J.A. Mondon, and R.M. Connolly. 2007. Estuarine fish health assessment: Evidence of wastewater impacts based on nitrogen isotopes and histopathology. Marine Pollution Bulletin 54: 1762-1776.

Scholz, S. and I. Mayer. 2008. Molecular biomarkers of endocrine disruption in small model fish. Molecular and Cellular Endocrinology 293: 57-70.

Starliper, C., V. Blazer, L. Iwanowicz and H. Walsh. 2013. Microbial isolates in diseased fishes, primarily smallmouth bass (Micropterus dolomieu), within the Chesapeake Bay drainage in 2009-2011. Proceedings of the West Virginia Academy of Science 85: 18-32.

Tetreault, G.R., C.J. Bennett, K. Shires, B. Knight, M.R. Servos, and M.E. McMaster. 2011. Intersex and reproductive impairment of wild fish exposed to multiple municipal wastewater discharges. Aquatic Toxicology 104: 278-290.

Valavanidis, A., T. Vlahogianni, M. Dassenakis, and M. Scoullos. 2006. Molecular biomarkers of oxidative stress in aquatic organisms in relation to toxic environmental pollutants. Ecotoxicology and Environmental Safety 64: 178-189.

Valencia, A., I. Rojo-Bartolomé, C. Bizarro, I. Cancio, M. Ortiz-Zarragoitia. 2017. Alteration in molecular markers of oocyte development and intersex condition in mullets impacted by wastewater treatment plant effluents. General and Comparative Endocrinology 245: 1018.

van Dyk, J.C., M.J. Marchand, N.J. Smit, and G.M. Pieterse. 2009. A histology-based fish health assessment of four commercially and ecologically important species from the Okavango Delta panhandle, Botswana. African Journal of Aquatic Science 34: 273-282.

Walsh, H.L., V.S. Blazer, L.R. Iwanowicz, and G. Smith. 2012. A redescription of Myxobolus inornatus from young-of-the-year smallmouth bass (Micropterus dolomieu). Journal of Parasitology 98: 1236-1242.

Wilcox, J.N. 2000. Overview of in situ hybridization methodology. Workshop - Visualizing neoplasia. Year 2000 Meetin gof the Histochemical Society. Available from: www.emory.edu/WILCOX/

Zhao, Y. and J. Hu. 2012. Development of a molecular biomarker for detecting intersex after exposure of male medaka fish to synthetic estrogen. Environmental Toxicology and Chemistry 31: 1765-1773. 


\section{Figures}

Figure 1. Smallmouth bass sampling sites where fish health assessments were conducted in the Potomac and Susquehanna River drainages and at sites outside of the Chesapeake Bay drainage. Subset: The Chesapeake Bay drainage (gray area).

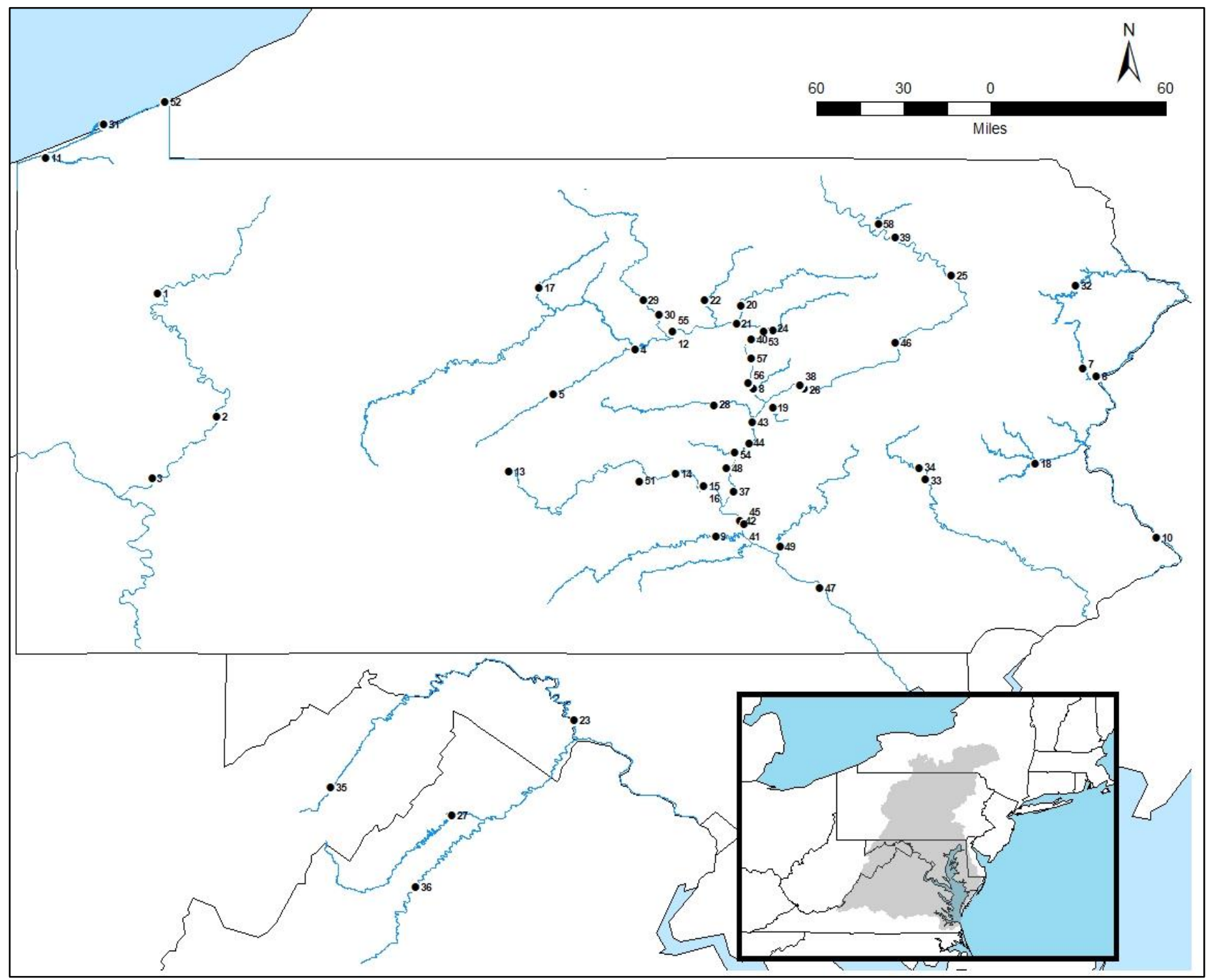




\section{Tables}

Table 1. Site names and coordinates where adult and/or young-of-the-year smallmouth bass were sampled in the Susquehanna, Allegheny, Delaware, Lake Erie, and Potomac River drainages.

\begin{tabular}{|c|c|c|c|}
\hline ID Number & Site Name & Latitude & Longitude \\
\hline 1 & Allegheny River @ Franklin & 41.3820 & -79.8200 \\
\hline 2 & Allegheny River @ Kitanning & 40.8126 & -79.5226 \\
\hline 3 & Allegheny River@ Oakmont & 40.5271 & -79.8464 \\
\hline 4 & Bald Eagle @ Castanea & 41.1243 & -77.4413 \\
\hline 5 & BaldEagle@ Unionville & 40.9154 & -77.8488 \\
\hline 6 & Brodhead Creek at Minisink Hills & 40.9985 & -75.1433 \\
\hline 7 & Brodhead Creek near East Stroudsburg & 41.0370 & -75.2100 \\
\hline 8 & Chillisquaque & 40.9420 & -76.8507 \\
\hline 9 & Conodoguinet Creek & 40.2595 & -77.0404 \\
\hline 10 & Delaware River at Yardley & 40.2532 & -74.8438 \\
\hline 11 & Elk River & 42.0050 & -80.3744 \\
\hline 12 & Jersey Shore & 41.2022 & -77.2527 \\
\hline 13 & Juniata River & 40.5608 & -78.0694 \\
\hline 14 & Juniata River (Thompsontown) & 40.5500 & -77.2400 \\
\hline 15 & Juniata River@ Howe Township Park & 40.4919 & -77.0968 \\
\hline 16 & Juniata River @ Newport & 40.4920 & -77.0980 \\
\hline 17 & Kettle Creek @ Leidy & 41.4051 & -77.9219 \\
\hline 18 & Lehigh River@ Canal Park & 40.5981 & -75.4496 \\
\hline 19 & Little Shamokin Creek & 40.8538 & -76.7564 \\
\hline 20 & Loyalsock & 41.3259 & -76.9122 \\
\hline 21 & Loyalsock Creek & 41.2410 & -76.9377 \\
\hline 22 & Lycoming Creek & 41.3505 & -77.0926 \\
\hline 23 & Mainstem Potomac River & 39.4143 & -77.7463 \\
\hline 24 & Muncy Creek & 41.2117 & -76.7569 \\
\hline 25 & North Branch Susquehanna @ Falls & 41.4617 & -75.8677 \\
\hline 26 & North Branch Susquehanna River @ Danville & 40.9436 & -76.5984 \\
\hline 27 & North Fork Shenandoah River & 38.9743 & -78.3551 \\
\hline 28 & Penns Creek & 40.8667 & -77.0497 \\
\hline 29 & Pine Creek@Hamilton Bottom & 41.3486 & -77.4019 \\
\hline 30 & Pine Creek @ Ramsey & 41.2830 & -77.3215 \\
\hline 31 & Presque Isle Bay & 42.1585 & -80.0855 \\
\hline 32 & Schultz Fish Hatchery & 41.4168 & -75.2495 \\
\hline 33 & Schuylkill River @ Berne & 40.5231 & -75.9972 \\
\hline 34 & Schuylkill River @ Port Clinton & 40.5772 & -76.0253 \\
\hline
\end{tabular}




\begin{tabular}{|l|c|c|c|}
35 & South Branch Potomac & 39.1041 & -78.9577 \\
36 & South Fork Shenandoah River & 38.6461 & -78.5345 \\
37 & Susquehanna @ Clemson Island & 40.4677 & -76.9483 \\
38 & Susquehanna @ Danville & 40.9591 & -76.6210 \\
39 & Susquehanna @ Laceyville & 41.6373 & -76.1483 \\
40 & Susquehanna @ Montgomery Access & 41.1696 & -76.8624 \\
41 & Susquehanna @ Rockville & 40.3186 & -76.8988 \\
42 & Susquehanna River @ Harrisburg & 40.3324 & -76.9172 \\
43 & Susquehanna River @ Isles of Ques & 40.7887 & -76.8568 \\
44 & Susquehanna River @ Port Trevorton & 40.6914 & -76.8750 \\
45 & Susquehanna River @ Rockville & 40.3186 & -76.8988 \\
46 & Susquehanna River @ Shickshinny & 41.1551 & -76.1452 \\
47 & Susquehanna River @ Wrightsville & 40.0249 & -76.5233 \\
48 & Susquehanna River@ Liverpool & 40.5741 & -76.9872 \\
49 & Swatara Creek & 40.2124 & -76.7210 \\
50 & Tionesta Lake & 41.4720 & 79.4420 \\
51 & Tuscarora Creek & 40.5160 & -77.4192 \\
52 & Twenty Mile Creek & 42.2622 & -79.7841 \\
53 & WB Susquehanna @ Muncy & 41.2061 & -76.8030 \\
54 & West Branch Mahantango Creek & 40.6478 & -76.9430 \\
55 & West Branch Susquehanna River @ Jersey Shore & 41.2022 & -77.2527 \\
56 & West Branch Susquehanna River @ Lewisburg & 40.9663 & -76.8778 \\
57 & West Branch Susquehanna River @ Watsontown & 41.0796 & -76.8633 \\
58 & Wyalusing Creek & 41.6975 & -76.2309 \\
\hline & Suln &
\end{tabular}




\title{
Chapter Two: Risk Factors Associated with Age-0 Smallmouth Bass Mortality in the Susquehanna River Basin, Pennsylvania, USA
}

\begin{abstract}
Evidence of disease and mortalities of age-0 Smallmouth Bass Micropterus dolomieu (SMB) has occurred during the late spring/summer in many parts of the Susquehanna River watershed since 2005. To better understand contributing factors, fish collected from multiple areas throughout the watershed as well as out-of-basin reference populations (Allegheny and Delaware River basins, experimental ponds Kearneysville, West Virginia) were examined grossly and histologically for abnormalities. Tissue contaminant concentrations were determined from whole body homogenates and water contaminant concentrations were estimated using time integrated passive samplers at selected sites. Observed or isolated pathogens included bacteria, predominantly motile Aeromonas spp. and Flavobacterium columnare; largemouth bass virus, and parasites, including trematode metacercariae, cestodes, and the myxozoan Myxobolus inornatus. Although these pathogens were found in AGE-0 SMB from multiple sites, no one pathogen was consistently associated with mortality. Chemicals detected in tissue included PCB congeners, organochlorine and current-use pesticides. Pyraclostrobin, PCB congeners 170 and 187, cis-chlordane and trans-nonachlor were detected in all Susquehanna samples but rarely in samples from the reference site. The findings support the idea that there is no single cause for disease of age-0 SMB; rather the cumulative effects of coinfections and potential immunomodulation by environmental stressors during a sensitive developmental life stage may lead to mortality. Identifying the most important risk factors will be necessary for more in-depth analyses of individual stressors and better management of the habitat and fish populations.
\end{abstract}




\section{Introduction}

Since 2005, disease and mortality of young-of-year (age-0) smallmouth bass Micropterus dolomieu have been documented at numerous sites within the Susquehanna River basin, Pennsylvania (Chaplin et al. 2009). Smallmouth bass (SMB) is not a native species but have been established in the drainage since the 1870s (Smith 1907; Stillwell et al. 1895) and is important ecologically as a top predator. It is economically important as a sportfish in the Susquehanna River and its tributaries, once considered a world-class fishery (Arway and Smith 2013). Hence, the recent disease issues have raised much public concern. Prior to 2005, based on a State-wide, fixed-site sampling network which began in the late 1980s and conducted during the mid to late-July index period, signs of disease and mortality of age-0 SMB had not been observed. However, mortality events since that time have resulted in low recruitment and a change in the population size structure (Smith et al. 2015) shifting to older and larger fish. Initial observations suggested age- 0 resulting in reduced adult abundance were occurring in the middle Susquehanna River (from Sunbury to York Haven, PA) and lower Juniata River from Port Royal to the confluence with the mainstem Susquehanna (Shull and Pulket 2015). However, since the initial observations, morbidity and mortalities have been documented in many other areas of the watershed, including smaller tributaries.

A number of avenues have been previously explored to determine the cause of disease and mortalities in age-0 SMB. Culture-based diagnoses have isolated a variety of pathogens including Flavobacterium columnare, motile Aeromonas spp., Pseudomonas aeruginosa and largemouth bass virus (Chaplin et al. 2009; Smith et al. 2015; Starliper et al. 2013). Although these pathogens are ubiquitous in the environment, they can become pathogenic to fish with 
other infections or immunosuppression (Camus et al. 1998; Grizzle and Brunner 2003; Loch and Faisal 2015) and can cause skin lesions and mortality. A re-described myxozoan parasite, Myxobolus inornatus has also been observed (Walsh et al. 2012). Despite having knowledge of these findings, it is currently not known if one of these pathogens is more detrimental or more widespread; nor has the issue of coinfections been addressed. In other species of fish, coinfections of bacteria, parasites and/or viruses are known to cause immunosuppression and mortality (Kotob et al. 2016). Furthermore, it has been documented that parasitic infections increase the risk of secondary bacterial infections (Pylkkö et al. 2006; Zhang et al. 2015).

Juvenile fish are especially susceptible to poor environmental conditions (Esteban 2012; Hrubec et al. 2004) due to having immature immune systems. The multiple pathogens already identified suggest these fish may be exposed to environmental stressors and are unable to resist infections. Water quality factors such as increased temperature and low dissolved oxygen have been examined but do not consistently correlate with disease presence (Chaplin et al. 2009; Chaplin and Crawford 2012). Contaminant exposure has not, to date, been evaluated as a possible stressor. However, numerous chemical contaminants are known to be immunomodulatory (Bols 2001; Dunier and Siwicki 1992; Lafferty and Holt 2003; Milla et al. 2011). Based on previous findings, a more comprehensive examination into the effects of contaminant exposure and coinfections is needed. The objectives of this study were to 1) summarize the current state of knowledge; 2) describe and evaluate microscopic pathological changes observed over multiple years; and 3) identify possible risk factors, including contaminant exposure and coinfections which may lead to decreased disease resistance.

\section{Materials and Methods}




\section{Fish Sample Collection}

Age-0 SMB were collected from four subbasins of the Susquehanna River watershed: lower Susquehanna, West Branch Susquehanna, middle Susquehanna, and Juniata (Figure 1). In late June through mid-July of 2007-2012, surveys (conducted by the Pennsylvania Fish and Boat Commission) targeting age-0 SMB were conducted within specific sites and reaches of these subbasins (Table 1). To collect fish, backpack electrofishers were used and the shoreline habitat typically utilized at that point in their ontogeny was targeted with a single-pass of the electrofishers. Initial survey design predates initial onset of disease and utilizes a Statewide (i.e., across drainages), fixed-site network intended to develop an index of relative abundance for predicting future year-class strength in large, semi-wadable rivers. Initial collections were of fish with visual lesions at these sites. Since the onset of overt disease, this survey period was also used to track prevalence of disease in addition to abundance of age-0 SMB. Hence, fish with no observable lesions were also randomly collected. Timing of surveys was standardized to collect fish approximately 35 to $75 \mathrm{~mm}$ total length to maintain consistent catchability and allow comparison of catch per unit effort (CPUE; fish/ $50 \mathrm{~m}$ ) among years. All age-0 SMB caught were visually assessed for obvious signs of clinical disease at the time of capture and humanely euthanized in tricane methansulfonate (Tricaine-S, Western Chemical, Inc., Ferndale, Washington). In 2010, the survey was extended to large tributary locations and out-of-basin reference sites (Delaware and Allegheny River basins) to compare sites with stable populations to those showing population declines utilizing the sampling protocols described above. These included the Allegheny River at Franklin, Delaware River at Morrisville, Pine Creek and Loyalsock Creek (Figure 1). Integrated passive water samplers were also deployed at a subset of 
these sites, including some sites with overt disease and population declines and some with no overt disease and stable populations (Table 2).

Microscopic Pathology

Fish for histology were collected and preserved in either $10 \%$ neutral buffered formalin or Z-fix ${ }^{\text {TM }}$ (Anatech LtD, Battle Creek. Michigan) and submitted to the Histopathology Laboratory of the U. S. Geological Survey's National Fish Health Research Laboratory in Kearneysville, West Virginia.

Whole fish were decalcified in Cal-Ex Decalcifier (Fisher Scientific, Pittsburgh, Pennsylvania), routinely processed and embedded into paraffin blocks which were sectioned at 5 $\mu \mathrm{m}$ and stained with hematoxylin and eosin (H \& E). Special stains utilized included Periodic Acid Schiff (PAS), Gram, and Giemsa (Luna 1992). Prevalence of organ specific lesions and parasites was determined by dividing the number of symptomatic fish by the total number of fish. Due to low sample size at most sites, samples were grouped according to subbasin of the Susquehanna, Juniata, lower, middle, and west branch, or by river, Allegheny and Delaware for out-of-basin reference sites (Table 1). Prevalence in the Susquehanna was also compared by grouping samples from the mainstem sites and tributary sites separately by subbasin.

The prevalence of coinfections was determined by including age- 0 with three or more infections (M. inornatus, muscle trematodes, liver trematodes, gut trematodes, gut cestodes, skin lesions, and systemic infections). The sites and samples included are listed in Table 1. Bacteriology or LMBV prevalence data were not included since access to these data for individual fish was not available. 
Chemical Analyses - Tissue

In 2011 age-0 SMB were collected (with the same collection regimen previously stated) from two sites by the Pennsylvania Fish and Boat Commission (Figure 1) on the mainstem Susquehanna River, Shady Nook near Shamokin Dam, Pennsylvania $(n=12)$ and Marysville, Pennsylvania $(n=4)$ for contaminant analyses. These are two sites where overt disease and population declines have been observed. As an out-of-basin comparison with a low potential of contaminant exposure, age-0 SMB $(n=10)$ were also randomly collected in mid-July after draining an experimental pond at the National Fish Health Research Laboratory in Kearneysville, West Virginia. The water source for the pond was Hopewell Run, a tributary of the Opequon Creek in the Potomac River basin. These fish were the offspring of adult Smallmouth Bass previously captured from the Potomac River which had spawned in the pond. Individual age-0 fish were wrapped in foil and stored frozen $\left(-20^{\circ} \mathrm{C}\right)$ until analyzed for a suite of current-use and legacy chemicals.

Individual fish were homogenized and in an aliquot of the homogenate a suite of organohalogenated compounds (Supplementary Table 1) were analyzed in individual samples at the U.S. Geological Survey’s (USGS) National Water Quality Laboratory, Denver, Colorado based on previously described methods (Burkhardt et al. 2005). Samples were extracted using pressurized liquid extraction followed by sample treatment using solid-phase extraction prior to analysis. The extracts were analyzed for 57 analytes using gas chromatography/mass spectrometry (GC/MS). Individual fish samples collected from Kearneysville ponds (n=10) ranged in size from 1.0 to $2.2 \mathrm{gm}$ wet weight (w wt). Individuals collected at the Susquehanna River sites (Marysville ( $n=4)$, Shady Nook $(n=12)$ were larger and ranged in size from 2.5 to 6.9 gm. 
A second aliquot of homogenates of age- 0 collected at the Shady Nook site $(n=5)$ and from the experimental ponds $(n=5)$ were sent to the U.S. Geological Survey's Organic Chemistry Research Laboratory, Sacramento, California to be analyzed for 98 pesticides and pesticide degradates by GC/MS (Supplementary table 2) based on previously published methods (Smalling et al. 2013).

\section{Water Chemical Sampling}

In 2010 time-integrated passive samplers, the polar organic chemical integrative sampler (POCIS) were deployed at four sites during the adult prespawn time period (spring) and at seven sites during the age- 0 developmental period (early summer) (Table 2). Polar organic chemical integrative samplers provide time-weighted data on water-soluble organic chemicals over time (weeks to months) from a single location (Alvarez et al. 2008). The prespawn deployment compared the Juniata River and Susquehanna River at Mahantango to sites in the Delaware and Allegheny Rivers. The sites compared during age-0 development were large river and tributary sites within the Susquehanna River watershed (Figure 1). After retrieval POCIS membranes were extracted with methanol and analyzed for 20 hormones or hormone-related compounds and 26 agricultural pesticides and pesticide metabolites (Supplementary table 3). Extracts designated for hormones were converted to trimethylsilyl derivatives and analyzed using GC/MS/MS as previously described (Alvarez et al. 2013; Foreman et al. 2012). Extracts designated for pesticides underwent additional processing prior to GC/MS analysis as described by Alvarez et al. (2008). Time-weighted average water concentrations were estimated from concentrations measured in the POCIS extracts as previously described (Alvarez 2010). 


\section{Results}

\section{Fish Collections}

The CPUE as assessed by the standardized sampling in large river reaches within the Susquehanna River watershed in 2009 - 2010 was well below the historic mean (1990-2002) for all areas except the upper Susquehanna River. Unfortunately, we have no fish samples from the upper Susquehanna River. In 2011-2012 the CPUE improved within the lower Juniata, upper Juniata and middle Susquehanna, while the middle Juniata, West Branch Susquehanna and lower Susquehanna showed little improvement (Table 3).

Within 2007-2012, a total of 339 fish were collected for this study. In the Susquehanna River basin, fish with a variety of visible lesions were observed swimming weakly at the water surface, prior to shocking. Lesions included discrete raised pale areas, primarily on the caudal area anterior to the caudal fin, but occasionally on other areas of the body, larger discolored areas on the body surface, and reddened and eroded fins (Figure 2). The directed sampling at river and tributary sites, as well as within larger reaches in 2010, found no fish with visible lesions at the out-of-basin Allegheny and Delaware River sites. No age-0 were caught in the Juniata River and visible lesions were observed at all river and tributary sites in the Susquehanna River watershed. Pine (2\%) and Loyalsock (5\%) Creeks had the lowest percentage of fish with visible lesions while Wyalusing Creek (78\%) and the West Branch Susquehanna River at Chillisquaque (67\%) had the highest. However, sample size was low at Wyalusing $(n=9)$ and Chillisquaque $(n=3$; Table 4).

Microscopic Pathology 


\section{$\underline{\text { Parasite-related Pathology }}$}

Parasitic infections, primarily larval cestodes, trematode metacercariae and myxozoans, were the most commonly documented microscopic lesions. Due to low sample size at multiple sites, prevalence data for microscopic observations (from every fish sampled) were determined by combining all years (2007-2012) and sites within the mainstem or tributaries of each subbasin and the Allegheny River, an out-of-basin reference site (Table 5). Larval cestodes in the liver caused extensive inflammatory responses (Figure 3A) consisting primarily of eosinophils and mononuclear cells and destroyed host tissue. Prevalence of larval cestodes in the liver was greater in the tributaries than mainstem sites in the lower and west branch Susquehanna River sites. No larval cestodes were observed in age-0 from the Allegheny River and prevalence was low in the lower (1.8\%) and West Branch Susquehanna (2.8\%) River mainstem sites. Encysted trematodes were observed in spleen, kidney, gastrointestinal tract and most often in skeletal muscle and liver and initiated either no or minor inflammatory responses (Figure 3B).

Prevalence of liver trematodes was higher in the tributaries of the lower and middle Susquehanna River sites than in the mainstem Susquehanna River and lowest in age-0 from the West Branch Susquehanna River subbasin. Trematode prevalence in the muscle was greater in age-0 from the mainstem Susquehanna sites than in age- 0 from the tributaries and highest in age- 0 from the Allegheny River basin at 90\%, however sample size was low $(n=10$; Table 5). No trematodes were observed in the muscle in age-0 from tributaries of the West Branch Susquehanna River. At some sites, fish were infected with adult cestodes in the lumen of the intestines and occasionally had multiple gut parasites, which also included encapsulated trematode cysts in the muscularis. Adult cestode infections did not seem to initiate a host response; however, encysted 
trematodes did occasionally cause a minor inflammatory reaction which primarily consisted of eosinophil infiltration around the cyst.

The other commonly observed microscopic lesions were associated with the myxozoan parasite $M$. inornatus. The infection involved muscle and connective tissue in multiple areas of the body including the esophagus, operculum, mouth, areas deep within the body musculature (not directly below the epithelium), and the dermis and muscle directly below the epithelium ventral to the dorsal fin and anterior to the caudal fin in the caudal peduncle. Identification of the myxozoan was based on morphology and tissue specificity as described in Walsh et al. (2012). Typical plasmodia were filled with sporozoites along the periphery and mature spores in the center (Figure 3C). Perforations or loss of epidermis was caused by enlargement of shallow plasmodium (Figure 3D). Most infections elicited mild to moderate host inflammatory responses consisting of fibrocytes, eosinophils, and lymphocytes. In some instances, however, ruptured plasmodia released mature spores initiating a more severe inflammatory response. Giemsastained slides showed spores present in many of these superficial inflammatory lesions. Prevalence of $M$. inornatus was greater in the tributaries of the lower (45.2\%) and middle (40.0\%) Susquehanna River than in the mainstem Susquehanna River sites $(28.8 \%$ and $25.0 \%$, respectively). Only one fish from the Allegheny River basin was infected with M. inornatus (Table 5).

\section{Bacteria-related Pathology}

The results and description of bacteria isolated in 2009-2011 from skin lesions and internally from the kidney are described by Starliper et al. (2013). The predominant bacterial species recovered from skin lesions were Aeromonas spp. and Flavobacterium columnare, 
however Citrobacter sp., Pseudomonas sp., and Plesiomonas shigelloides were also isolated (Starliper et al. 2013). Severe skin infections included necrotic epithelium, dermis, and muscle, with inflammation and occasional fungal hyphae. Milder signs of infection consisted of acute inflammation in the epidermis, dermis, hypodermis, and muscle. Instances of inflammation in the connective tissue channeling through myocytes were observed. Areas most commonly infected were in and around the mouth, along the lateral line, and around the anal and caudal fins. Prevalence of skin lesions identified with histopathology are provided in Table 5. No skin lesions were identified with histopathology at the Allegheny River sites. Skin lesions were highest in the mainstem sites of the middle Susquehanna River subbasin (66.7\%) and lowest in the tributaries of the West Branch Susquehanna River subbasin (8.9\%). Both of the tributary sites in the lower Susquehanna River subbasin and middle Susquehanna River subbasin had a higher prevalence of skin lesions (58.1\% and $66.7 \%$, respectively) than the mainstem sites (29.7\% and $54.5 \%$, respectively).

\section{Pathology of Unidentified Etiology}

Systemic infections in the eye, liver, spleen, gastrointestinal tract, and around the spinal cord and notochord were observed (Figure 3E \& 3F). The cause of the infections, which consisted of granulomatous inflammation with necrosis, was not identified. The prevalence of these systemic lesions (found in any of the aforementioned tissues) was highest at sites in the mainstem middle Susquehanna River subbasin (69.7\%) and lowest in the tributaries of the west branch Susquehanna River subbasin (4.2\%; Table 5). It was not observed in fish from the Allegheny River. Prevalence of systemic infections was greater at the mainstem middle (69.7\%) and West Branch Susquehanna River sites (16.7\%) than in their corresponding tributaries (33.3\% 
and $4.2 \%$, respectively). In the lower Susquehanna River subbasin, prevalence was greater in the tributary sites $(32.3 \%)$ than in the mainstem sites $(17.1 \%)$.

\section{$\underline{\text { Coinfections }}$}

Prevalence of age- 0 with coinfections of three or more pathogens is listed in Table 5. A total of 76 fish from all sites had coinfections with three or more pathogens. The greatest percentage of age- 0 with coinfections was from the tributaries in the lower Susquehanna River subbasin (58.1\%). In the out-of-basin Allegheny River sites, only 1 fish had coinfections. Age-0 from the West Branch Susquehanna River subbasin had a lower prevalence of coinfections than the lower and middle Susquehanna and Juniata River subbasins.

\section{Chemical Contaminants}

\section{$\underline{\text { Tissue Contaminants }}$}

Thirty-four of the 56 organohalogen compounds were detected in at least one individual fish. There were more compounds in fish from the Susquehanna River when compared to the out-of-basin reference fish from an experimental pond in Kearneysville, West Virginia. Ten compounds were found in fish from Kearneysville and the total detects in an individual fish ranged from one to six. Conversely, 32 compounds were detected in individuals collected at the combined Susquehanna River sites (Marysville and Shady Nook) with one to sixteen detects per individual (Table 6).

A number of compounds were only detected in fish from the Susquehanna River. These

included ten polychlorinated biphenyl (PCB) congeners; three brominated diphenyl ether (BDE) 
congeners; eleven pesticides and the antimicrobial triclosan (Table 6). Only one compound, PCB congener 180, was found in almost all of the fish.

Six of the 98 pesticides and pesticide degradates were detected in at least one individual. The fungicide pyraclostrobin, the herbicide pendimethalin and the legacy insecticide p,p'-DDT were only detected in fish from the Susquehanna (Table 7).

\section{$\underline{\text { Integrated Passive Samplers }}$}

A total of nine hormone or hormone-related analytes were detected in the POCIS extracts in the spring. Seven compounds were detected at the Juniata River, Susquehanna River, and Delaware River sites while only two, cholesterol and 4-androstene-3,17-dione were detected at the Allegheny River site (Table 8). A total of six agricultural pesticides and pesticide metabolite analytes were detected in the POCIS extracts in the spring (Table 8). The Delaware River and Allegheny River sites had more pesticide detects (five each) than either the Susquehanna River (two) or Juniata River (four) sites.

Chemical analyses of POCIS deployed in early summer during egg hatching and larval development period indicated different exposures among sites. Cholesterol, estrone and 4androstene-3,17-dione were measured at all sites. The Juniata River and Susquehanna River at Mahantango had the highest estrone concentrations, Susquehanna River at Danville, Chillisquaque and Wyalusing creeks were intermediate and Loyalsock and Pine creeks had the lowest concentration. Juniata River, Susquehanna River at Mahantango and Danville and Wyalusing Creek also had measurable amounts of 17- $\beta$-estradiol, while only the Juniata River had detectable concentrations of 17- $\alpha$-estradiol. The agricultural pesticides and related compounds measured during the period of egg hatching and larval development were herbicides. 
Atrazine and its metabolite desethylatrazine were measured at all sites, although estimated concentrations varied greatly and the highest concentrations were measured at the Juniata site. Simazine was also highest at the Juniata site. Prometon and metolachlor were measured at all sites except Loyalsock and Pine creeks and the highest concentrations were measured at the Juniata River site (Table 9).

\section{Discussion}

The results of this study emphasize the need to better understand the role of coinfections and environmental risk factors, such as chemical contaminants, which contribute to adverse health effects in wild fishes. Often identification of "the cause" of wild fish disease focuses on one particular pathogen. Indeed, initially the mortality of age-0 SMB in the Susquehanna was attributed to F. columnare (Chaplin et al. 2009; Chaplin and Crawford 2012). Increasingly investigators are recognizing the need to understand the cumulative, synergistic or antagonistic impacts of multiple stressors on disease in wild fish populations (Lafferty and Holt 2003; Miller et al. 2014). Lesions associated with both microbial and parasitic pathogens in SMB, generally less than three months of age, suggests a degraded ecosystem in which environmental stressors may play a role in infectious disease initiation and progression. Juvenile fish are especially susceptible to poor environmental conditions due to immature lymphoid and skin organs (Esteban 2012; Hrubec et al., 2004). Even as young fish develop more advanced immune responses, changes in water quality such as temperature, dissolved oxygen, and $\mathrm{pH}$, can disrupt their normal function (Uribe 2011). Such disruptions may lead to mortality and affect populations, which are possibly evidenced by lower CPUE in four of the five subbasins of the 
Susquehanna River in 2009-2012 when compared to historic means (the mean of years 1990 through 2002).

Pathogens observed or isolated from age-0 included M. inornatus, trematodes in multiple organs, cestodes in the gut and liver, multiple bacterial species ( $F$. columnare, Aeromonas veronii bv. sobria, and P. shigelloides), and largemouth bass virus (Starliper et al. 2013). Additionally, a systemic, granulomatous infection with necrosis was observed in multiple organs, but the cause remains unknown. Many age- 0 also had coinfections of these pathogens. The variety of microbial and parasitic agents, difference in prevalence of various infections among sites, and the lack of an obvious "cause" emphasizes the importance of considering the role of coinfections and underlying environmental stressors on mortality of age-0 SMB. Age-0 from the Juniata River and lower and middle Susquehanna River subbasins had higher rates of parasitism, coinfections and skin lesions (Table 5) than age-0 SMB in the West Branch Susquehanna River subbasin, which had some of the lowest rates of coinfections, skin lesions, and systemic infections.

The types of parasites observed in this study may affect age-0 SMB in different ways. Many studies have found that younger fish have a harder time coping with parasite infections (Sitja-Bobadilla 2008) and coinfections of parasites can induce immunosuppression (Kotob et al. 2016). In age-0 SMB infected with larval cestodes in the liver, damage to the tissue was greatest and included severe inflammation and areas of necrosis, similar to what was observed in Spotted Bass Micropterus punctulatus (Joy and Madan 1989), and Bluegill Lepomis macrochirus (Mitchell et al. 1983). In the connective tissue of the muscle, M. inornatus oftentimes did not initiate a host response; however, severe inflammation was occasionally found around ruptured cysts in the muscle. Lastly, trematodes infecting age-0 SMB liver and skin were found 
encapsulated within the tissue and may impact hosts by replacing normal tissue. Grizzle and Goldsby (1996) also noted that trematodes in SMB have the potential to damage lymphatic tissue in the gut, which plays a major role in immune function (Wu et al. 2016). These types of parasites may also increase microbial infection rates and mortality by enhancing bacterial or viral invasion. Cestode, trematode, and M. inornatus infective stages entering the fish could create perforations in the skin and digestive tract and open pathways for invasion, breakdown mucus to achieve invasion (Gomez et al. 2014), and indirectly enhance microbial infections (Kotob et al. 2016; Labrie et al. 2004; Roon et al. 2015). Morrison et al. (1981) demonstrated that F. columnare could only be transmitted to fish with breaks in the epidermis and not fish with normal, intact skin. Many of the age-0 SMB in this study were found to have coinfections of parasites in addition to bacteria and LMBV (Starliper et al. 2013); thus the cumulative effects caused by these parasites and pathogens should be considered.

Differences in parasite loads between sites were also observed and could be due to available habitat and food sources for the intermediate hosts. For example, even though liver trematode infection was highest in the lower Susquehanna River tributaries, it was lowest in age0 from the lower Susquehanna River mainstem which could be due to a decrease in intermediate hosts or a decrease in abundance of the parasites due to adverse environmental conditions (Landsberg et al. 1998). This may also contribute to the greater prevalence of liver trematodes in all tributary versus mainstem sites. Additionally, differences in immune defenses among fish, differences in habitat utilization and parasite availability, and exposure to bacterial pathogens may cause variances in parasite prevalence. It is likely that environmental stressors play a role both in pathogen population dynamics as well as host-pathogen interactions. Although nutrient loads have generally decreased throughout the Susquehanna River drainage they remain a major 
concern in specific areas (Zhang et al. 2016). Excessive nutrients together with elevated temperature have been recognized as factors that can accelerate bacterial growth rate and hence infective dose (Wedekind et al. 2010). High environmental nutrient concentrations affected the expression of virulence genes leading to increased mortality of rainbow trout experimentally exposed to $F$. columnare (Penttinen et al. 2016). Another major effect of elevated nutrients is increased algal and periphyton biomass (Schindler 2006) and consequently the increase of certain benthic invertebrates that act as intermediate hosts for fish parasites (Johnson et al. 2007; McKenzie and Townsend 2007). Although the intermediate host of M. inornatus remains unknown, organic nutrients (favored by myxozoan intermediate hosts) may be associated with the differences in prevalence observed amongst the subbasins of the Susquehanna River. The highest prevalence was found in fish from the middle Susquehanna River tributary sites and lowest in fish from the out-of-basin Allegheny River sites. Similar to what was observed with liver trematodes, age-0 SMB from tributary sites in the lower and middle Susquehanna River subbasins had higher M. inornatus prevalence than the mainstem sites.

Chemical contaminants can have direct and indirect complex effects on the health of aquatic organisms and can exacerbate parasite-induced immunosuppression (Jacobson et al. 2003). These effects vary with species and life stage, and juvenile fish in particular may be more sensitive than adults to chemical exposures. The chemical data in this study provide insight on the types of contaminants to which age-0 are exposed. In the spring when SMB spawn, the agricultural chemicals atrazine and metolachlor and the hormones 4-androstene-3,17-dione and cholesterol were detected with integrated passive samplers at all sites. In the summer, atrazine, desethylatrazine, and metolachlor and the hormones estrone and cholesterol were detected at all sites. Age-0 sampled from the West Branch Susquehanna River had the lowest prevalence of 
disease (Table 4) and less hormones and agricultural chemicals were detected with POCIS at these sites during the summer (Table 9). Conversely, disease was greatest in the Juniata, lower, and middle Susquehanna River subbasins where the greatest number of hormones and agricultural chemicals were detected. Many pollutants (Bols et al. 2001; Duffy et al. 2002; Dunier and Siwicki 1993) including hormones and hormone mimicking compounds (Milla et al. 2011) are known to modulate the immune system of fishes. Some of the chemicals detected in this study can affect health in multiple ways. For instance, estrogenic compounds can directly influence the immune system of fishes (Milla et al. 2011) and may also increase parasite growth rates within host tissues (Macnab et al. 2016). Numerous immune function endpoints were inhibited and pathogen infection rates increased in fishes after exposure to atrazine (Kreutz et al. 2012; Liu et al. 2017; Rohr and McCoy 2010). Similarly, metolachlor has been shown to have detrimental endocrine and physiological effects on fish (Quintaneiro et al. 2017). The levels of atrazine, which ranged from 1.0-36.0 ng/L and metolachlor, which ranged from BD-18.0 ng/L were relatively low, however studies have shown that low levels of atrazine (Hayes 2004) and mixtures including atrazine and metolachlor (Shinn et al. 2015) have endocrine disrupting and behavioral effects. The synergistic or additive effects of mixtures of the agricultural chemicals and hormones and coinfections of parasites and pathogens found in this study remain unknown; however, evidence suggests that they exacerbate disease.

In age-0 SMB tissue, the three agricultural contaminants with the greatest number of detects were pp'-DDE, bifenthrin, and pyraclostrobin. Bifenthrin, a pyrethroid insecticide insoluble in water but with a relatively long half-life (8-17 months) in sediment (Gan et al. 2005), has immunomodulatory effects in fishes (Jin et al. 2009). It has been shown to have effects at various trophic levels by reducing larval macroinvertebrate (insect) abundance, 
richness and biomass, as well as increasing periphyton abundance (Rogers et al. 2016). Larval macroinvertebrates, particularly insect larvae consume the cercariae, or infective stage of trematode parasites (Schotthoefer et al. 2007). A decrease in macroinvertebrates could allow cercariae populations to increase and cause infection rates to increase in susceptible hosts. In fish, the fungicide pyraclostrobin, was shown to induce oxidative stress and DNA damage (Zhang et al. 2017) and has an extremely high acute toxicity (Mellish 2013). In Largemouth Bass, p,p'-DDE had endocrine disrupting effects in both male and female fish (Garcia-Reyero et al. 2006; Larkin et al. 2002). Ultimately, the overlapping increase in parasite abundance and immunosuppression caused by contaminant exposure may increase overall pathogen infection rates in age-0 SMB with excessive nutrients exacerbating the problem. Seven organohalogens were also detected in the tissue of all age-0 SMB from the Susquehanna River, three of which were not detected in the age-0 SMB from the out-of-basin reference site in Kearneysville. These included dieldrin, cis-chlordane, and trans-nonachlor, which have been associated with dysregulation of immune function (Cowie et al. 2017; Tryphonas et al. 2003).

Our study identified numerous parasites and contaminants in the tissues of age-0 SMB and chemicals of emerging concern in the water during a sensitive developmental life stage. Although no one cause of disease and mortality was identified, the findings provide further evidence that multiple factors may have an impact on age-0 SMB survival. Identifying key environmental factors which regulate these pathogens will be necessary for addressing management needs. The low CPUE of age-0 SMB during this study indicates that the risk factors examined here may have a direct impact on future population dynamics. The findings illustrate the importance of taking a comprehensive approach at understanding the underlying risk factors for disease rather than focusing on the effects of individual pathogens, water quality, or 
contaminants alone. The system provides a unique opportunity to study the effects of multiple pathogen infections and environmentally relevant concentrations of contaminants in a wild, nonmodel, species of fish. Additional studies documenting spatial and temporal trends in prevalence of the various pathogens and parasites and the host response, in association with climatic factors, land use, water quality and chemical contaminants will be necessary to identify effective management actions for a healthier fish population.

\section{References}

Alvarez, D.A., W.L. Cranor, S.D. Perkins, R.C. Clark, and S.B. Smith. 2008. Chemical and toxicological assessment of organic contaminants in surface water using passive samplers. Journal of Environmental Quality 37:1024-1033.

Alvarez, D.A. 2010. Guidelines for the use of the semipermeable membrane device (SPMD) and the polar organic chemical integrative sampler (POCIS) in environmental monitoring studies: U.S. Geological Survey, Techniques and Methods 1-D4, 28p. Available: http://pubs.usgs.gov/tm/tm1d4/. (January 2017).

Alvarez, D.A., N.W. Shappell, L.O. Billey, D.S. Bermudez, V.S. Wilson, D.W. Kolpin, S.D. Perkins, N. Evans, W.T. Foreman, J.L. Gray, M.J. Shipitalo, and M.T. Meyer. 2013. Bioassay of estrogenicity and chemical analyses of estrogens in streams across the United States associated with livestock operations. Water Research 2013: 3347-3363.

Arway, J.A., and G. Smith. 2013. The Susquehanna River-A Fishery in Decline. Fisheries 38: 235-236.

Bols, N.C., J.L. Brubacher, R.C. Ganassin, and L.E.J. Lee. 2001. Ecotoxicology and innate immunity in fish. Developmental and Comparative Immunology 25: 853-873.

Burkhardt, M.R., R.C. ReVello, S.G. Smith, and S.D. Zaugg. 2005. Pressurized liquid extraction using water/isopropanol coupled with solid-phase extraction cleanup for industrial and anthropogenic waste-indicator compounds in sediment. Analytica Chimica Acta 534: 89-100.

Camus, A.C., R.M. Durborow, W.G. Hemstreet, R.L. Thune, and J.P. Hawke. 1998. Aeromonas bacterial infections - Motile Aeromonad Septicemia. Southern Regional Aquaculture Center 478: 1-4. 
Chaplin, J.J., J.K. Crawford, and R.A. Brightbill. 2009. Water quality monitoring in response to young-of-the-year smallmouth bass (Micropterus dolomieu) in the Susquehanna River and major tributaries, Pennsylvania - 2006. U.S. Geological Survey Open-File Report 2009-1216.

Chaplin, J.J., and J.K. Crawford. 2012. Streamflow and water-quality monitoring in response to young-of-year smallmouth bass (Micropterus dolomieu) mortality in the Susquehanna River and major tributaries, with comparisons to the Delaware and Allegheny Rivers, Pennsylvania, 2008-10. U.S. Geological Survey Open-File Report, 2012-1019.

Cowie, A.M., K.I. Sarty, A. Mercer, J. Koh, K.A. Kidd, C.J. Martyniuk. 2017. Molecular networks related to the immune system and mitochondria are targets for the pesticide dieldrin in the zebrafish (Danio rerio) central nervous system. Journal of Proteomics 157: 71-82.

Duffy, J.E., E. Carlson, Y. Li, C. Prophete, and J.T. Zelikoff. 2002. Impact of polychlorinated biphenyls (PCBs) on the immune function of fish: age as a variable in determining adverse outcome. Marine Environmental Research 54: 559-563.

Dunier, M., and A.K. Siwicki. 1993. Effect of pesticides and other organic pollutants in the aquatic environment on immunity of fish: a review. Fish and Shellfish Immunology 3: 423-438.

Esteban, M.A. 2012. An overview of the immunological defenses in fish skin. International Scholarly Research Network 2012: 1-29.

Foreman, W.T., J.L. Gray, R.C. ReVello, C.E. Lindley, S.A. Losche, and L.B. Barber. 2012. Determination of steroid hormones and related compounds in filtered and unfiltered water by solid-phase extraction, derivatization, and gas chromatography with tandem mass spectrometry. U.S. Geological Survey Techniques and Methods, book 5 sec. B, chap. 9, 118 p. Available:http://pubs.usgs.gov/tm/5b9. (February 2017).

Gan, J., S.J. Lee, W.P. Liu, D.L. Haver, and J.N. Kabashima. 2005. Distribution and persistence of pyrethroids in runoff sediments. Journal of Environmental Quality 34:836-841.

Garcia-Reyero, N., D.S. Barber, T.S. Gross, K.G. Johnson, M.S. Sepúlveda, N.J. Szabo, and N.D. Denslow. 2006. Dietary exposure of largemouth bass to OCPs changes expression of genes important for reproduction. Aquatic Toxicology 78: 358-369.

Gomez, D., J. Bartholomew, and J.O. Sunyer. 2014. Biology and mucosal immunity to myxozoans. Developmental \& Comparative Immunology 43: 243-256.

Grizzle, J.M. and C.J. Brunner. 2003. Review of largemouth bass virus. Fisheries 28: 10-14. 
Grizzle, J.M. and M.T. Goldsby Jr. 1996. White grub Posthodiplostomum minimum centrarchi metacercariae in the liver of largemouth bass: quantification and effects on health. Journal of Aquatic Animal Health 8:70-74.

Hayes, T.B. 2004. There is no denying this: defusing the confusion about atrazine. Bioscience 54: 1138-1149.

Hrubec, T.C., D. Ward, S.A. Smith, and J.L. Robertson. 2004. Age related changes in humoral immune response of hybrid striped bass (Morone chrysops x Morone saxatilis). Veterinary Immunology and Immnopathology 101: 103-108.

Jacobson, K.C., M.R. Arkoosh, A.N. Kagley, E.R. Clemons, T.K. Collier, and E. Casillas. 2003. Cumulative effects of natural and anthropogenic stress on immune function and disease resistance in juvenile chinook salmon. Journal of Aquatic Animal Health 15: 1-12.

Jin, M., X. Zhang, L. Wang, C. Huang, Y. Zhang, and M. Zhao. 2009. Developmental toxicity of bifenthrin in embryo-larval stages of zebrafish. Aquatic Toxicology 95: 347-354.

Johnson, P.T., J.M. Chase, K.L. Dosch, R.B. Hartson, J.A. Gross, D.J. Larson, D.R. Sutherland, and S.R Carpenter. 2007. Aquatic eutrophication promotes pathogenic infection in amphibians. Proceedings of the National Academy of Sciences 104: 15781-15786.

Joy, J.E. and E. Maden. 1989. Pathology of black bass hepatic tissue infected with larvae of the tapeworm Proteocephalus ambloplitis. Journal of Fish Biology 35: 111-118.

Kotob, M.H., S. Menanteau-Ledoble, G. Kumar, M. Abdelzaher, and M. El-Matbouli. 2016. The impact of coinfections on fish: a review. Veterinary Research 47: 1-12.

Kreutz, L.C., L.J.G. Barcellos, E.D. dos Santos, M. Pivato, and R. Zanatta. 2012. Innate immune response of silver catfish (Rhamdia quelen) exposed to atrazine. Fish \& Shellfish Immunology 33:1055-1059.

Labrie, L., C. Komer, J. Terhune, A. Camus, and D. Wise. 2004. Effect of sublethal exposure to the trematode Bolbophorus spp. on the severity of enteric septicemia of catfish in channel catfish fingerlings. Journal of Aquatic Animal Health 16: 231-237.

Lafferty, K.D., and R.D. Holt. 2003. How should environmental stress affect the population dynamics of disease? Ecology Letters 6: 654-664.

Landsberg, J.H., B.A. Blakesley, R.O. Reese, G. Mcrae, and P.R. Forstchen. 1998. Parasites of fish as indicators of environmental stress. Environmental Monitoring and Assessment 51: 211-232.

Larkin, P., T. Sabo-Attwood, J. Kelso, and N.D. Denslow. 2002. Gene expression analysis of largemouth bass exposed to estradiol nonylphenol, and $p, p$ '-DDE. Comparative Biochemistry and Physiology Part B 133: 543-557. 
Liu, Z., Z. Fu, and Y. Jin. 2017. Immunotoxic effects of atrazine and its main metabolites at environmental relevant concentrations on larval zebrafish (Danio rerio). Chemosphere 166: 212-220.

Loch, T.P., and M. Faisal. 2015. Emerging flavobacterial infections in fish: a review. Journal of Advanced Research 6: 283-300.

Luna, L. 1992. Histopathologic methods and color atlas of special stains and tissue artifacts. American Histolabs, Inc., Gaithersburg, Maryland.

Macnab, V., I. Katsiadaki, C.A. Tilley, and I. Barber. 2016. Oestrogenic pollutants promote the growth of a parasite in male sticklebacks. Aquatic Toxicology 174: 92-100.

McKenzie, V.J., and A.R. Townsend. 2007. Parasitic and infectious disease responses to changing global nutrient cycles. EcoHealth 4: 384-396.

Mellish, S. 2013. Acute toxicity hazard of pesticides to freshwater fish.

http://www.gov.pe.ca/photos/original/af_factrel1299.pdf. Accessed 10-13-17.

Milla, S., S. Depiereux, and P. Kestemont. 2011. The effects of estrogenic and androgenic endocrine disruptors on the immune system of fish: a review. Ecotoxicology 20: 305319.

Miller, K.M., A. Teffer, S. Tucker, S. Li, A.D. Schulze, M. Trudel, F. Juanes, A. Tabata, K.H. Kaukinen, N.G. Ginther, T.J. Ming, S.J. Cooke, J.M. Hipfner, D.M. Patterson, and S.G. Hinch. 2014. Infectious disease, shifting climates, and opportunistic predators: cumulative factors potentially impacting wild salmon declines. Evolutionary Applications $7: 812-855$.

Mitchell, L.G., J. Ginal, and W.C. Bailey. 1983. Melanotic visceral fibrosis associated with larval infections of Posthodiplostomum minimum and Proteocephalus sp. in bluegill, Lepomis macrochirus Rafinesque, in central Iowa, U.S.A. Journal of Fish Diseases 6: 135-144.

Morrison, C., J. Cornick, S. Shum, and B. Zwicker. 1981. Microbiology and histopathology of 'saddleback' disease of underyearling Atlantic salmon, Salmo salar L. Journal of Fish Diseases 4: 243-258.

Penttinen, R., H. Kinnula, A. Lipponen, J.K.H. Bamford, and L-R. Sundberg. 2016. High nutrient concentration can induce virulence factor expression and cause higher virulence in an environmentally transmitted pathogen. Microbial Ecology 72:955-964.

Pylkkö, P., L-R. Suomalainen, M. Tiirola, and E.T. Valtonen. 2006. Evidence of enhanced bacterial invasion during Diplostomum spathaceum infection in European grayling, Thymallus thymallus (L.). Journal of Fish Diseases 29: 79-86. 
Quintaneiro, C., D. Patrício, S.C. Novais, A.M.V.M. Soares, and M.S. Monteiro. 2017. Endocrine and physiological effects of linuron and S-metolachlor in zebrafish developing embryos. Science of the Total Environment 586: 390-400.

Rogers, H.A., T.S. Schmidt, B.L. Dabney, M.L. Hladik, B.J. Mahler and P.C. Van Metre. 2016. Bifenthrin causes trophic cascade and altered insect emergence in mesocosms: Implications for small streams. Environmental Science and Technology 50:11974-11983.

Rohr, J.R., and K.A. McCoy. 2010. A qualitative meta-analysis reveals consistent effects of atrazine on freshwater fish and amphibians. Environmental Health Perspectives 118: 2032.

Roon, S.R., J.D. Alexander, K.C. Jacobson, and J.L. Bartholomew. 2015. Effect of Nanophyetus salmincola and bacterial co-infection on mortality of juvenile chinook salmon. Journal of Aquatic Animal Health 27: 209-216.

Schindler, D.W. 2006. Recent advances in the understanding and management of eutrophication. Limnology and Oceanography 51:356-363.

Schotthoefer, A.M., K.M. Labak, and V.R. Beasley. 2007. Ribeiroia ondatrae cercariae are consumed by aquatic invertebrate predators. Journal of Parasitology 93:1240-1243.

Shinn, C., M.M. Santos, S. Lek, and G. Grenouillet. 2015. Behavioral response of juvenile rainbow trout exposed to an herbicide mixture. Ecotoxicology and Environmental Safety 112: $15-21$.

Shull, D., and M. Pulket. 2015. Causal analysis of the smallmouth bass decline in the Susquehanna and Juniata Rivers. Available: http://files.dep.state.pa.us/Water/ Drinking\%20Water\%20Regulation/WaterQualityPortalFiles/SusquehannaRiverStudyUpd ate/SMB_CADDIS_report.pdf. (March 2017).

Sitja-Bobadilla, A. 2008. Living off a fish: a trade-off between parasites and the immune system. Fish and Shellfish Immunology 25: 358-372.

Smalling, K.L., G.M. Fellers, P.M. Kleeman, and K.M. Kuivila. 2013. Accumulation of pesticides in pacific chorus frogs (Pseudacris regilla) from California's Sierra Nevada Mountains, USA. Environmental Toxicology and Chemistry 32: 2026-2034.

Smith, H.M. 1907. Our fish immigrants. National Geographic Magazine, June 1907, pp. 384400.

Smith, G.D., V.S. Blazer, H.L. Walsh, L.R. Iwanowicz, and C. Starliper. 2015. The effects of disease-related mortality of young-of-year smallmouth bass on population characteristics in the Susquehanna River basin, Pennsylvania and potential implications to conservation of black bass diversity. American Fisheries Society Symposium 82: 319-332. 
Starliper, C., V. Blazer, L. Iwanowicz, and H. Walsh. 2013. Microbial isolates in diseased fishes, primarily smallmouth bass (Micropterus dolomieu), within the Chesapeake Bay drainage in 2009-2011. Proceeding of the West Virginia Academy of Science 85: 18-32.

Stillwell, S.B., H.C. Demuth, L. Streuber, H.C. Ford, J.A. Dale and D.P. Corwin. 1895. Report of the State Commissioners of Fisheries, Year 1895. Pages 215-220. Fish Commissioners of Pennsylvania, Harrisburg, PA.

Tryphonas, H., G. Bondy, M. Hodgen, L. Coady, M. Parenteau, C. Armstrong, S. Hayward, and V. Liston. 2003. Effects of cis-nonachlor, trans-nonachlor and chlordane on the immune system of Sprague-Dawley rats following a 28-day oral (gavage) treatment. Food and Chemical Toxicology 41: 107-118.

Uribe, C., H. Folch, R. Enriquez, and G. Moran. 2011. Innate and adaptive immunity in teleost fish: a review. Veterinarni Medicina 56: 486-503.

Walsh, H.L., V.S. Blazer, L.R. Iwanowicz, and G. Smith. 2012. A redescription of Myxobolus inornatus from young-of-the-year Smallmouth Bass (Micropterus dolomieu). Journal of Parasitology 98: 1236-1242.

Wedekind, C., M.O. Gessner, F. Vazquez, M. Maerki, and D. Steiner. 2010. Elevated resource availability sufficient to turn opportunistic into virulent fish pathogens. Ecology 91: 1251-1256.

Wu, N. Y-L. Song, B. Wang, X-Y. Zhang, X-J. Zhang, Y-L. Wang, Y-Y. Cheng, D-D. Chen, XQ. Xia, Y-S. Lu, and Y-A. Zhang. 2016. Fish gut-liver immunity during homeostasis or inflammation revealed by integrative transcriptome and proteome studies. Scientific Reports 6: 1-17.

Zhang, Q., W.P. Ball, and D.L. Moyer. 2016. Decadal-scale export of nitrogen, phosphorus, and sediment from the Susquehanna River basin, USA: Analysis and synthesis of temporal and spatial patterns. Science of the Total Environment 563:1016-29.

Zhang, X., S. Wang, S. Chen, Y. Chen, Y. Liu, C. Shao, Q. Wang, Y. Lu, G. Gong, S. Ding, and Z. Sha. 2015. Transcriptome analysis revealed changes of multiple genes involved in immunity in Cynoglossus semilaevis during Vibrio anguillarum infection. Fish and Shellfish Immunology 43: 209-218.

Zhang, C., J. Wang, S. Zhang, L. Zhu, Z. Du, and J. Wang. 2017. Acute and subchronic toxicity of pyraclostrobin in zebrafish (Danio rerio). 2017. Chemosphere 188: 510-516. 


\section{Figures}

Figure 1. Sampling sites used to collect age-0 smallmouth bass from the Susquehanna River basin and its tributaries and the Allegheny and Delaware Rivers from 2007 to 2012.

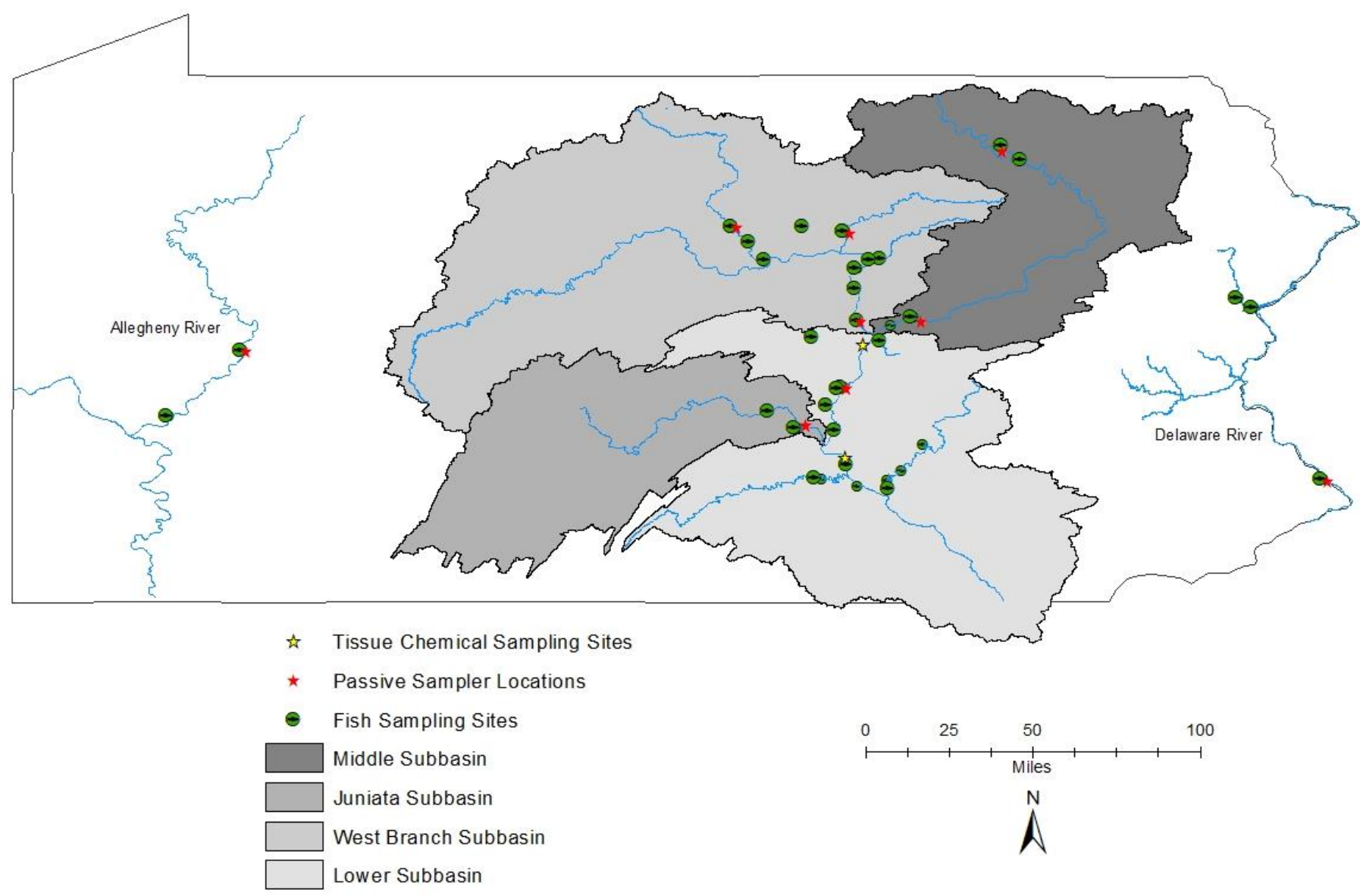


Figure 2. Lesions observed visually on age-0 Smallmouth Bass. (A) Small raised cysts (arrows) on the ventral surface. (B) Pale raised areas (arrows) on the lateral body surface. (C) A raised and eroded area (arrow) on the caudal area. (D) Eroded and reddened area (a) surrounded by a discoloration (b) on the lateral body surface. (E) Eroded and reddened areas (arrow) on the lateral body surface. (F) Eroded caudal fin (arrow).

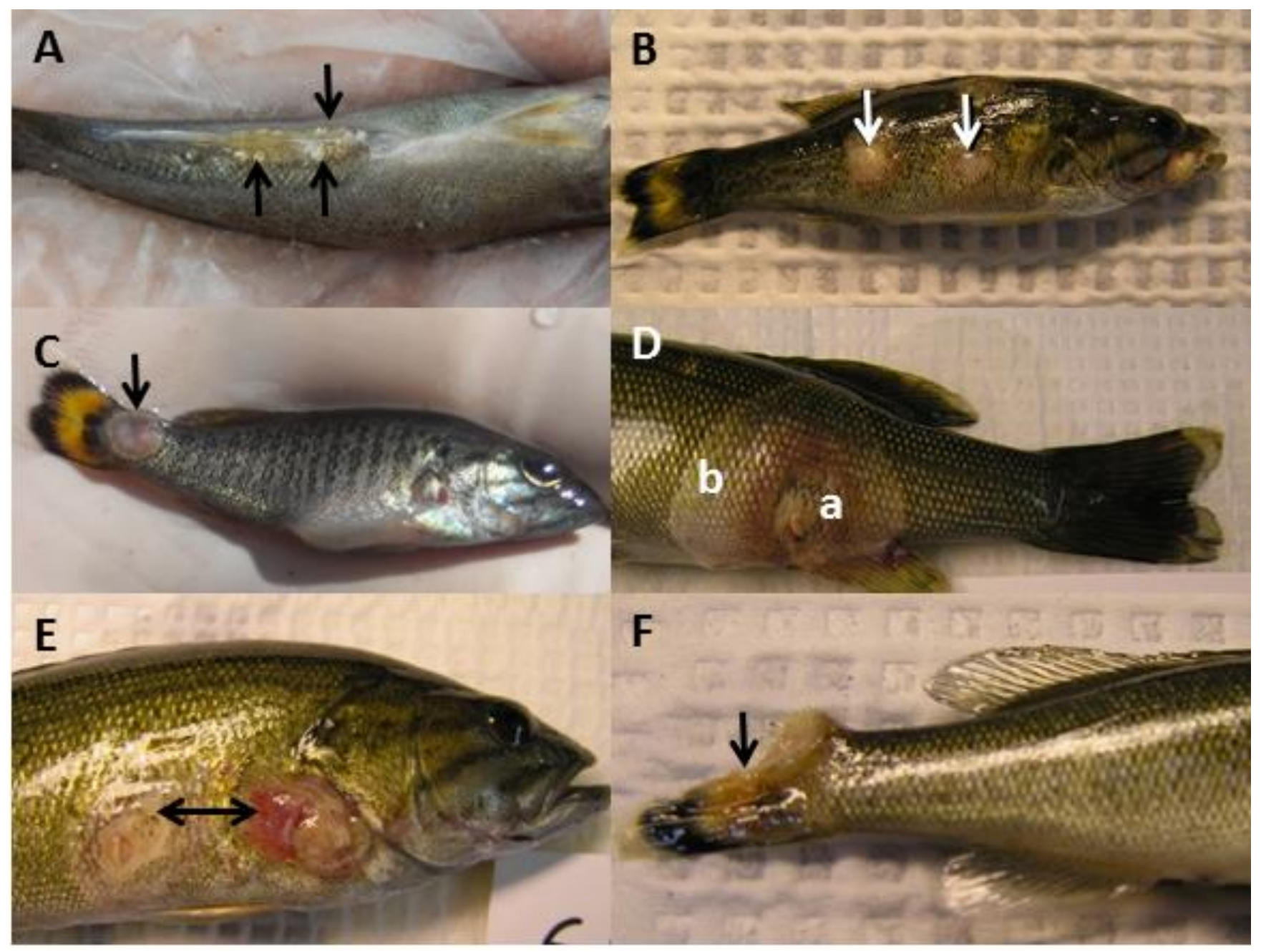


Figure 3. Microscopic pathology associated with parasite and systemic infections in age-0 Smallmouth Bass (hematoxylin and eosin stain). (A) Larval cestodes (a) within the liver causing significant inflammation and necrosis (arrows). Scale bar $=150 \mu \mathrm{m}$. (B) Multiple trematode cysts (a) within the skeletal muscle (b). Scale bar $=100 \mu \mathrm{m}$. (C) Myxobolus inornatus plasmodium (arrows) eliciting inflammation (a) within subdermal tissue. Plasmodium contains mature spores in the central region (b) and sporozoites (c) along the periphery. Scale bar $=100$ $\mu \mathrm{m}$. (D) Myxobolus inornatus plasmodia (a) causing a thinning and perforations of the epidermis (arrows) as they enlarge. Scale bar $=150 \mu \mathrm{m}$. (E) Focus of inflammation (a) within the submucosa of the stomach (b). Scale bar $=150 \mu \mathrm{m}$. (F) Focus of inflammation (a) within the liver (b). Scale bar $=150 \mu \mathrm{m}$.

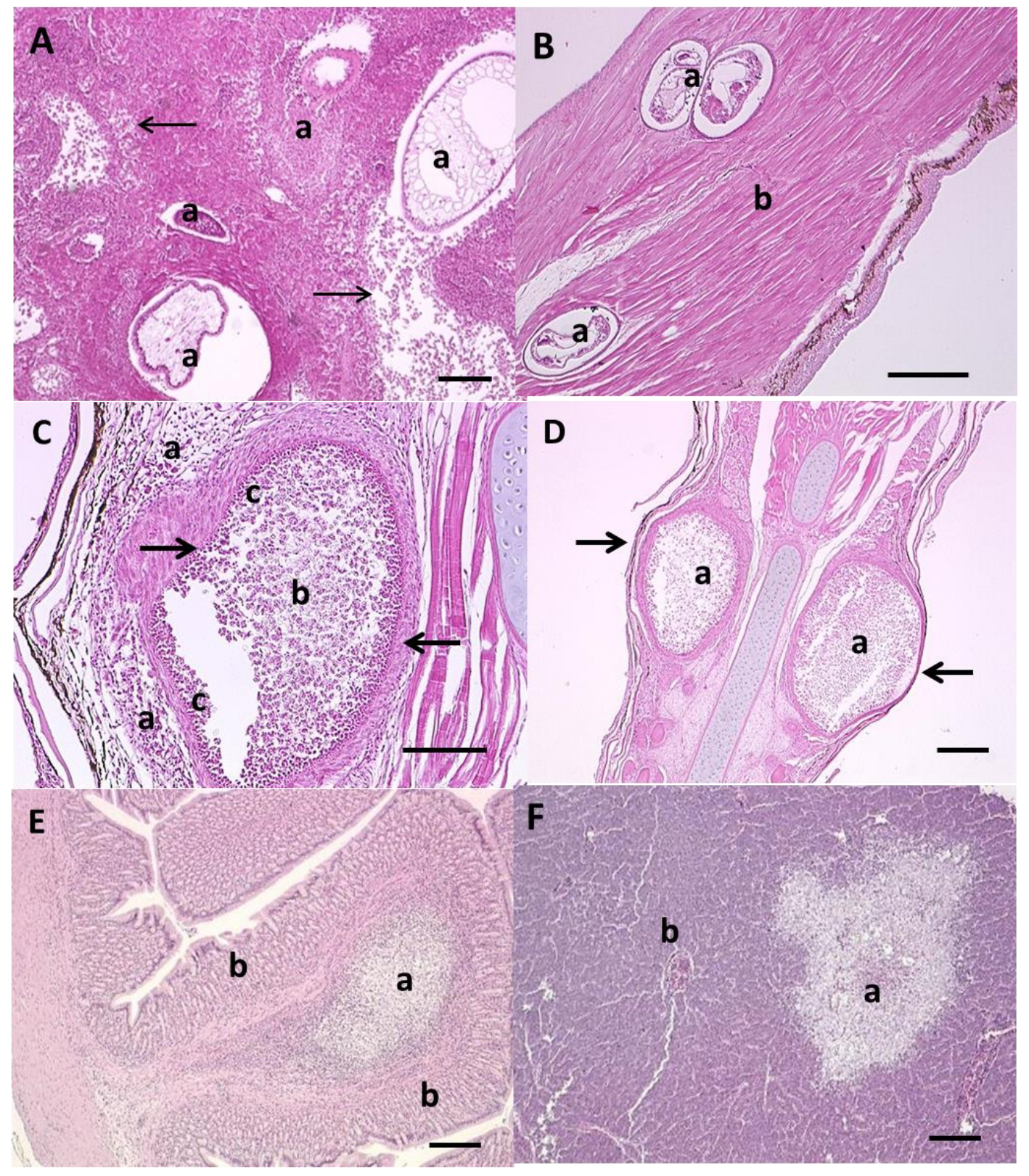




\section{Tables}

Table 1. Sampling sites and analyses conducted on age-0 smallmouth bass in the Susquehanna River basin and out-of-basin reference sites between 2007 through 2012 .

\begin{tabular}{|c|c|c|c|c|c|c|}
\hline Site & Sub-basin & $\begin{array}{c}\text { Year } \\
\text { Collected }\end{array}$ & $\begin{array}{c}\text { \# Fish } \\
\text { Sampled }\end{array}$ & Histopathology & Bacteriology & $\begin{array}{c}\text { Tissue Chemical } \\
\text { Analysis }\end{array}$ \\
\hline Allegheny River (Mosgrove) & Out-of-basin & 2010 & 5 & $\mathrm{Y}$ & $\mathrm{N}$ & $\mathrm{N}$ \\
\hline Allegheny River (Kitanning) & Out-of-basin & 2010 & 5 & $\mathrm{Y}$ & $\mathrm{N}$ & $\mathrm{N}$ \\
\hline Schuylkill River & Out-of-basin & 2010 & 2 & $\mathrm{Y}$ & $\mathrm{N}$ & $\mathrm{N}$ \\
\hline Leetown Science Center, Kearneysville, WV & Out-of-basin & 2011 & 10 & $\mathrm{~N}$ & $\mathrm{~N}$ & $\mathrm{Y}$ \\
\hline Juniata (Granville) & Juniata & 2007 & 4 & $\mathrm{Y}$ & $\mathrm{N}$ & $\mathrm{N}$ \\
\hline Juniata River & Juniata & 2010 & 12 & $\mathrm{Y}$ & $\mathrm{Y}$ & $\mathrm{N}$ \\
\hline Susquehanna River (Shady Nook) & Lower Susquehanna & 2007 & 4 & $\mathrm{Y}$ & $\mathrm{N}$ & $\mathrm{N}$ \\
\hline Susquehanna River (Shady Nook) & Lower Susquehanna & 2011 & 8 & $\mathrm{Y}$ & $\mathrm{Y}$ & $\mathrm{N}$ \\
\hline Susquehanna River (Shady Nook) & Lower Susquehanna & 2011 & 12 & $\mathrm{~N}$ & $\mathrm{~N}$ & $\mathrm{Y}$ \\
\hline Susquehanna River (Shady Nook) & Lower Susquehanna & 2012 & 4 & $\mathrm{Y}$ & $\mathrm{N}$ & $\mathrm{N}$ \\
\hline Susquehanna River (Liverpool) & Lower Susquehanna & 2009 & 29 & $\mathrm{Y}$ & $\mathrm{N}$ & $\mathrm{N}$ \\
\hline Susquehanna River (Liverpool) & Lower Susquehanna & 2010 & 7 & $\mathrm{Y}$ & $\mathrm{Y}$ & $\mathrm{N}$ \\
\hline Susquehanna River (Liverpool) & Lower Susquehanna & 2011 & 21 & $\mathrm{Y}$ & $\mathrm{N}$ & $\mathrm{N}$ \\
\hline Susquehanna River (Clemson Island) & Lower Susquehanna & 2009 & 16 & $\mathrm{Y}$ & $\mathrm{N}$ & $\mathrm{N}$ \\
\hline Susquehanna RIver (Clemson Island) & Lower Susquehanna & 2010 & 7 & $\mathrm{Y}$ & $\mathrm{Y}$ & $\mathrm{N}$ \\
\hline Susquehanna River (Clemson Island) & Lower Susquehanna & 2011 & 4 & $\mathrm{Y}$ & $\mathrm{Y}$ & $\mathrm{N}$ \\
\hline Susquehanna River (Rockville) & Lower Susquehanna & 2012 & 4 & $\mathrm{Y}$ & $\mathrm{N}$ & $\mathrm{N}$ \\
\hline Susquehanna River (Mahantango) & Lower Susquehanna & 2009 & 3 & $\mathrm{Y}$ & $\mathrm{N}$ & $\mathrm{N}$ \\
\hline Susquehanna River (Marysville) & Lower Susquehanna & 2011 & 4 & $\mathrm{~N}$ & $\mathrm{~N}$ & $\mathrm{Y}$ \\
\hline Susquehanna River & Lower Susquehanna & 2010 & 21 & $\mathrm{Y}$ & $\mathrm{N}$ & $\mathrm{N}$ \\
\hline Penn's Creek & Lower Susquehanna & 2010 & 12 & $\mathrm{Y}$ & $\mathrm{N}$ & $\mathrm{N}$ \\
\hline Swatara Creek & Lower Susquehanna & 2010 & 10 & $\mathrm{Y}$ & $\mathrm{N}$ & $\mathrm{N}$ \\
\hline Swatara Creek & Lower Susquehanna & 2011 & 3 & $\mathrm{Y}$ & $\mathrm{N}$ & $\mathrm{N}$ \\
\hline Conodoguinet Creek & Lower Susquehanna & 2011 & 6 & $\mathrm{Y}$ & $\mathrm{N}$ & $\mathrm{N}$ \\
\hline Susquehanna River (Danville) & Middle Susquehanna & 2007 & 5 & Y & $\mathrm{N}$ & $\mathrm{N}$ \\
\hline
\end{tabular}


Susquehanna River (Danville)

Susquehanna River (Laceyville)

Susquehanna River (Laceyville)

$$
\begin{aligned}
& \text { Wyalusing Creek } \\
& \text { Wyalusing Creek } \\
& \text { Wyalusing Creek }
\end{aligned}
$$

Susquehanna River (Montgomery Access)

Susquehanna River (Montgomery Access)

West Branch Susquehanna (Muncy)

West Branch Susquehanna

West Branch Susquehanna

Susquehanna River (Jersey Shore)

Little Shamokin Creek

\section{Muncy Creek}

Lycoming Creek

Loyalsock Creek

Loyalsock Creek

\section{Pine Creek}

Chillisquaque Creek
Middle Susquehanna

Middle Susquehanna

2010

Middle Susquehanna

Middle Susquehanna

Middle Susquehanna

Middle Susquehanna

West Branch

Susquehanna

West Branch

Susquehanna

West Branch

Susquehanna

West Branch

Susquehanna

West Branch

Susquehanna

West Branch

Susquehanna

West Branch

Susquehanna

West Branch

Susquehanna

West Branch

Susquehanna

West Branch

Susquehanna

West Branch

Susquehanna

West Branch

Susquehanna

West Branch

Susquehanna 
Table 2. Sites and dates for deployment of integrated passive water sampling devices in the spring and summer.

\begin{tabular}{lcccc}
\hline \multicolumn{1}{c}{ Site Location } & $\begin{array}{c}\text { Lat/Long } \\
\text { Coordinates }\end{array}$ & $\begin{array}{c}\text { Deployment } \\
\text { Date }\end{array}$ & $\begin{array}{c}\text { Retrieval } \\
\text { Date }\end{array}$ & $\begin{array}{c}\text { Days } \\
\text { Deployed }\end{array}$ \\
& $40.4910 \mathrm{~N} ;-77.0995 \mathrm{~W}$ & $04 / 21 / 2010$ & $06 / 01 / 2010$ & 41 \\
Juniata River, Newport & $40.6515 \mathrm{~N} ;-76.9228 \mathrm{~W}$ & $04 / 21 / 2010$ & $06 / 01 / 2010$ & 41 \\
Susquehanna River, Mahantango & $40.2514 \mathrm{~N} ;-74.8414 \mathrm{~W}$ & $04 / 21 / 2010$ & $06 / 03 / 2010$ & 45 \\
Delaware River, Yardley & $40.8138 \mathrm{~N} ;-79.5252 \mathrm{~W}$ & $04 / 28 / 2010$ & $06 / 07 / 2010$ & 40 \\
Allegheny River, Kittanning & $40.4910 \mathrm{~N} ;-77.0995 \mathrm{~W}$ & $06 / 29 / 2010$ & $08 / 02 / 2010$ & 34 \\
\hline Juniata River, Newport & $40.6515 \mathrm{~N} ;-76.9228 \mathrm{~W}$ & $06 / 29 / 2010$ & $08 / 02 / 2010$ & 34 \\
Susquehanna River, Mahantango & $40.9414 \mathrm{~N} ;-76.8654 \mathrm{~W}$ & $06 / 29 / 2010$ & $08 / 02 / 2010$ & 34 \\
Susquehanna River, Chillisquaque & $40.9434 \mathrm{~N} ;-76.5986 \mathrm{~W}$ & $06 / 29 / 2010$ & $08 / 02 / 2010$ & 34 \\
Susquehanna River, Danville & $41.6778 \mathrm{~N} ;-76.2515 \mathrm{~W}$ & $06 / 28 / 2010$ & $08 / 03 / 2010$ & 36 \\
Wyalusing Creek, Wyalusing & $41.3250 \mathrm{~N} ;-76.9121 \mathrm{~W}$ & $06 / 28 / 2010$ & $08 / 03 / 2010$ & 36 \\
Loyalsock Creek, Montoursville & $41.3491 \mathrm{~N} ;-77.4017 \mathrm{~W}$ & $06 / 28 / 2010$ & $08 / 03 / 2010$ & 36 \\
Pine Creek, Jersey Mills & & & & \\
\hline
\end{tabular}


Table 3. Historic and recent catch per unit effort (CPUE) ${ }^{1}$ of young-of-year smallmouth bass in reaches of the Susquehanna River drainage.

\begin{tabular}{lccccc}
\hline \multicolumn{1}{c}{ Reach } & $\begin{array}{c}\text { CPUE } \\
\text { 2009 }\end{array}$ & $\begin{array}{c}\text { CPUE } \\
2010\end{array}$ & $\begin{array}{c}\text { CPUE } \\
2011\end{array}$ & $\begin{array}{c}\text { CPUE } \\
2012\end{array}$ & $\begin{array}{c}\text { Historic } \\
\text { Mean }^{2}\end{array}$ \\
\hline Lower Juniata & 0.15 & 0.15 & 0.92 & 3.46 & 3.43 \\
Middle Juniata & 0.02 & 0.40 & 1.80 & 0.56 & 6.33 \\
Upper Juniata & 0.31 & 1.77 & 9.15 & 5.23 & 7.00 \\
West Branch Susquehanna & 0.41 & 1.55 & 1.00 & 0.50 & 4.50 \\
Upper Susquehanna & 3.41 & 19.60 & 7.90 & 11.60 & 5.87 \\
Middle Susquehanna & 0.15 & 1.72 & 2.55 & 4.10 & 7.80 \\
Lower Susquehanna & 0.33 & 0.71 & 0.90 & 0.63 & 3.76 \\
\hline
\end{tabular}

${ }^{1}$ Catch per unit effort (CPUE) is the \# of fish collected per $50 \mathrm{~m}$

${ }^{2}$ Historic mean is based on data from 1990 through 2002. 
Table 4. Prevalence of disease and catch per unit effort (CPUE) at large river and tributary sites during directed sampling in 2010.

\begin{tabular}{|ccccc|}
\hline River reaches and sites & $\begin{array}{c}\text { CPUE } \\
(\# / 50 \mathrm{~m})\end{array}$ & $\begin{array}{c}\text { Total } \\
\text { Catch }\end{array}$ & $\begin{array}{c}\text { \# Visible } \\
\text { Lesions }\end{array}$ & $\begin{array}{c}\text { Disease } \\
\text { Prevalence (\%) }\end{array}$ \\
\hline Allegheny River reach & 0.7 & 17 & 0 & 0 \\
Kittanning site & 1.3 & 8 & 0 & 0 \\
\hline Delaware River reach & 5.1 & 122 & 0 & 0 \\
Yardley site & 0.7 & 4 & 0 & 0 \\
\hline Juniata River reach & 0 & 0 & NA & NA \\
Greenwood site & 0 & 0 & NA & NA \\
\hline Susquehanna River reach & 1.9 & 72 & 7 & 10 \\
Mahantango site & 2.7 & 16 & 2 & 13 \\
\hline North Branch Susquehanna reach & 11.3 & 272 & 3 & 1 \\
Danville site & 1.5 & 9 & 2 & 22 \\
\hline West Branch Susquehanna reach & 1.5 & 80 & 37 & 46 \\
Chillisquaque site & 0.5 & 3 & 2 & 67 \\
\hline Wyalusing Creek & 1.5 & 9 & 7 & 5 \\
\hline Loyalsock Creek & 3.2 & 19 & 1 & 2 \\
\hline Pine Creek & 8.5 & 51 & 1 & \\
\hline
\end{tabular}


Table 5. Combined prevalence (2007-2012) of microscopic observations in smallmouth bass young-of-year collected from the Allegheny River and Susquehanna River sub-basins. Co-infection prevalence was calculated to include fish with three or more infections including skin lesions, systemic infections, and parasite infections.

\begin{tabular}{|c|c|c|c|c|c|c|c|c|c|}
\hline Sites & Subbasin & $\begin{array}{c}\text { Sample } \\
\text { Size }\end{array}$ & $\begin{array}{c}\text { Prevalence } \\
\text { Systemic } \\
\text { Infections (\%) }\end{array}$ & $\begin{array}{l}\text { Prevalence } \\
\text { Skin } \\
\text { Lesions (\%) }\end{array}$ & $\begin{array}{l}\text { Trematode } \\
\text { Prevalence } \\
\text { Liver }(\%)\end{array}$ & $\begin{array}{l}\text { Trematode } \\
\text { Prevalence } \\
\text { Muscle (\%) }\end{array}$ & $\begin{array}{c}\text { M. inornatus } \\
\text { Prevalence } \\
(\%)\end{array}$ & $\begin{array}{l}\text { Larval Cestode } \\
\text { Prevalence } \\
\text { Liver }(\%)\end{array}$ & $\begin{array}{c}\text { Prevalence of } \\
\text { Coinfections } \\
(\%)\end{array}$ \\
\hline Allegheny & & 10 & 0 & 0 & 20.0 & 90.0 & 10.0 & 0.0 & 10.0 \\
\hline Juniata & Juniata & 15 & 40.0 & 33.3 & 40.0 & 40.0 & 26.7 & 40.0 & 35.3 \\
\hline \multirow{2}{*}{$\begin{array}{c}\text { Susquehanna } \\
\text { Tributaries }\end{array}$} & \multirow{2}{*}{ Lower } & 111 & 17.1 & 29.7 & 8.1 & 52.3 & 28.8 & 1.8 & 24.3 \\
\hline & & 31 & 32.3 & 18.0 & 35.5 & 48.4 & 45.2 & 54.8 & 58.1 \\
\hline \multirow{2}{*}{$\begin{array}{c}\text { Susquehanna } \\
\text { Tributaries }\end{array}$} & \multirow{2}{*}{ Middle } & 33 & 69.7 & 57.1 & 21.4 & 32.1 & 25.0 & 39.3 & 36.4 \\
\hline & & 15 & 33.3 & 60.0 & 40.0 & 6.7 & 40.0 & 40.0 & 33.3 \\
\hline \multirow{2}{*}{$\begin{array}{c}\text { Susquehanna } \\
\text { Tributaries }\end{array}$} & \multirow{2}{*}{ West Branch } & 36 & 16.7 & 13.9 & 8.3 & 41.7 & 30.6 & 2.8 & 13.9 \\
\hline & & 45 & 4.2 & 8.3 & 6.3 & 0.0 & 27.1 & 12.5 & 4.4 \\
\hline
\end{tabular}


Table 6. Range ( $\mu \mathrm{g} / \mathrm{kg}$ wet weight) and number of detects (in parentheses) of organohalogens measured in tissues of young-of-year smallmouth bass collected from a pond at the Leetown Science Center (reference site; $\mathrm{n}=10)$ and Susquehanna River $(\mathrm{n}=16)$.

\begin{tabular}{lcc}
\hline Analyte & \multicolumn{2}{c}{ Collection Location } \\
& Leetown Ponds & Susquehanna River \\
\hline PCB 110 & BD $^{1}$ & $0.79-1.00(2)$ \\
PCB 118 & BD & $1.0(1)$ \\
PCB 146 & BD & $0.21^{2}-0.34(7)$ \\
PCB 149 & BD & $0.39-1.80(3)$ \\
PCB 151 & BD & $0.31-0.53(2)$ \\
PCB 170 & $0.22(1)$ & $0.12-0.73(16)$ \\
PCB 174 & BD & $0.12-0.74(14)$ \\
PCB 177 & BD & $0.11-0.57(13)$ \\
PCB 180 & $0.11-0.13(9)$ & $0.08-0.65(16)$ \\
PCB 183 & BD & $0.10-0.57(14)$ \\
PCB 194 & BD & $0.04-0.23(10)$ \\
PCB 187 & $0.15-0.16(2)$ & $0.07-0.61(16)$ \\
PCB 206 & BD & $0.04-0.09(14)$ \\
Dieldrin & BD & $0.30-2.30(16)$ \\
Pentachloroanisole & BD & $0.12-0.34(11)$ \\
Methyl triclosan & BD & $13(1)$ \\
Triclosan & BD & $14.00-36.00(4)$ \\
cis-Chlordane & BD & $0.76-1.90(16)$ \\
cis-Nonachlor & BD & $0.07-0.31(15)$ \\
trans-Chlordane & BD & $0.05-0.20(12)$ \\
trans-Nonachlor & BD & $0.42-1.50(16)$ \\
Desulfinylfipronil & BD & $0.11-0.26(4)$ \\
Chlorpyrifos & BD & $0.16-0.53(7)$ \\
Endosulfan sulfate & BD & $0.15-0.24(2)$ \\
BDE 47 & BD & $3.8-6.7(9)$ \\
BDE 66 & BD & $0.17-3.2(6)$ \\
BDE 154 & BD & $0.23-0.23(2)$ \\
BDE 85 & $0.11-0.97(2)$ & BD \\
BDE 138 & $0.08-0.13(2)$ & BD \\
BDE 99 & $1.20-6.70(5)$ & $0.56-2.30(16)$ \\
BDE 100 & $0.33-0.98(7)$ & $0.15-1.80(13)$ \\
BDE 153 & $0.11-1.80(2)$ & $0.19-0.28(4)$ \\
Hexachlorobenzene & $0.06-0.11(7)$ & $0.20-0.94(9)$ \\
p,p'-DDE & $1.90-4.60(2)$ & $9.80-14.00(2)$ \\
\hline
\end{tabular}

${ }^{1} \mathrm{BD}=$ Below detection

${ }^{2}$ Values in italics are estimated values are above the method detection limit but below the reporting limit. 
Table 7. The range in concentration ( $\mu \mathrm{g} / \mathrm{kg}$ wet weight) and number of detects (in parentheses) of pesticides, herbicides, and fungicides measured in whole body homogenates of young-of-year smallmouth bass. Five individual fish from each site were analyzed.

\begin{tabular}{lcc}
\hline Analyte & \multicolumn{2}{c}{ Collection Location } \\
& Leetown Ponds & Susquehanna River \\
\hline pp'-DDE & $9.2-17.2(4)$ & $2.5-18.8(5)$ \\
pp'-DDT & $\mathrm{BD}^{1}$ & $2.3-3.6(2)$ \\
Pendimethalin & $\mathrm{BD}$ & $3.5(1)$ \\
Bifenthrin & $15.7(1)$ & $12.6-20.3(3)$ \\
Chlorothalonil & $1.2-1.5(2)$ & $\mathrm{BD}$ \\
Pyraclostrobin & $\mathrm{BD}$ & $5.7-19.4(5)$ \\
\hline
\end{tabular}

${ }^{1} \mathrm{BD}=$ below detection. 
Table 8. Estimated time-weighted average water concentrations (ng/L) of hormones and agricultural chemicals determined from integrated passive samplers deployed during the spring.

\begin{tabular}{lcccc}
\hline \multicolumn{1}{c}{ Analyte } & $\begin{array}{c}\text { Juniata at } \\
\text { Newport }\end{array}$ & $\begin{array}{c}\text { Susquehanna } \\
\text { at Mahantango }\end{array}$ & $\begin{array}{c}\text { Delaware at } \\
\text { Yardley }\end{array}$ & $\begin{array}{c}\text { Allegheny at } \\
\text { Kittanning }\end{array}$ \\
\hline Hormones & & & & \\
cis-androsterone & 0.03 & 0.04 & 0.04 & BD $^{1}$ \\
4-androstene-3,17-dione & 0.52 & 0.47 & 0.83 & 0.32 \\
Testosterone & 0.09 & 0.10 & $\mathrm{BD}$ & $\mathrm{BD}$ \\
17-alpha estradiol & 0.08 & 0.08 & $\mathrm{BD}$ & $\mathrm{BD}$ \\
17- beta estradiol & 0.24 & 0.27 & 0.15 & $\mathrm{BD}$ \\
Estrone & 0.72 & 0.71 & 0.74 & $\mathrm{BD}$ \\
Equilenin & $\mathrm{BD}$ & $\mathrm{BD}$ & 0.16 & $\mathrm{BD}$ \\
Estriol & $\mathrm{BD}$ & $\mathrm{BD}$ & 0.092 & $\mathrm{BD}$ \\
cholesterol & 52 & 52 & 60 & 53 \\
& & & & \\
Agricultural chemicals & & & & \\
desethylatrazine & 2.6 & $\mathrm{BD}$ & 4.9 & 2.0 \\
atrazine & 5.7 & 2.7 & 15.0 & 15.0 \\
simazine & $\mathrm{BD}$ & $\mathrm{BD}$ & $\mathrm{BD}$ & 3.8 \\
prometon & 0.36 & $\mathrm{BD}$ & 0.45 & $\mathrm{BD}$ \\
acetochlor & $\mathrm{BD}$ & $\mathrm{BD}$ & 1.9 & 0.9 \\
metolachlor & 1.7 & 1.5 & 4.0 & 4.3 \\
\hline
\end{tabular}

${ }^{1} \mathrm{BD}=$ below detection

${ }^{2}$ Values in italics are estimated concentrations or values that are above the method detection limit but below the method quantitation limit. 
Table 9. Estimated time-weighted average water concentrations (ng/L) of hormones and agricultural chemicals determined from integrated passive samplers deployed during the summer.

\begin{tabular}{|c|c|c|c|c|c|c|c|}
\hline Analyte & $\begin{array}{l}\text { Juniata at } \\
\text { Newport }\end{array}$ & $\begin{array}{l}\text { Susquehanna at } \\
\text { Mahantango }\end{array}$ & $\begin{array}{l}\text { Susquehanna } \\
\text { at Danville }\end{array}$ & $\begin{array}{l}\text { Susquehanna at } \\
\text { Chillisquaque }^{1}\end{array}$ & $\begin{array}{l}\text { Loyalsock } \\
\text { Creek }^{1}\end{array}$ & $\begin{array}{c}\text { Pine } \\
\text { Creek }^{1}\end{array}$ & $\begin{array}{c}\text { Wyalusing } \\
\text { Creek }^{1}\end{array}$ \\
\hline \multicolumn{8}{|l|}{ Hormones } \\
\hline 4-androstene-3,17-dione & 0.33 & 0.43 & 0.47 & 0.44 & 0.15 & 0.22 & 0.33 \\
\hline 17-alpha estradiol & 0.20 & $\mathrm{BD}^{2}$ & $\mathrm{BD}$ & $\mathrm{BD}$ & $\mathrm{BD}$ & $\mathrm{BD}$ & $\mathrm{BD}$ \\
\hline 17- beta estradiol & 0.27 & 0.11 & 0.10 & $\mathrm{BD}$ & $\mathrm{BD}$ & $\mathrm{BD}$ & 0.07 \\
\hline Estrone & 1.60 & 1.20 & 0.82 & 0.88 & 0.10 & 0.32 & 0.88 \\
\hline Cholesterol & 72 & 49 & 100 & 33 & 44 & 50 & 41 \\
\hline \multicolumn{8}{|l|}{ Agricultural chemicals } \\
\hline Desethylatrazine & 19.0 & 10.0 & 4.8 & 13.0 & 1.5 & 1.3 & 3.2 \\
\hline Atrazine & 36.0 & 18.0 & 7.9 & 15.0 & $1.0^{3}$ & 1.2 & 4.8 \\
\hline Simazine & 37.0 & 2.7 & 2.1 & $\mathrm{BD}$ & 2.0 & $\mathrm{BD}$ & 1.9 \\
\hline Prometon & 7.5 & 2.2 & 0.9 & 1.7 & $\mathrm{BD}$ & $\mathrm{BD}$ & 0.7 \\
\hline Metolachlor & 18.0 & 5.9 & 2.6 & 3.4 & $\mathrm{BD}$ & 0.3 & 1.7 \\
\hline Fipronil & $\mathrm{BD}$ & $\mathrm{BD}$ & 2.6 & $\mathrm{BD}$ & 1.3 & $\mathrm{BD}$ & $\mathrm{BD}$ \\
\hline Terbuthylazine & $\mathrm{BD}$ & 1.1 & 0.65 & $\mathrm{BD}$ & $\mathrm{BD}$ & $\mathrm{BD}$ & $\mathrm{BD}$ \\
\hline
\end{tabular}

${ }^{1}$ Susquehanna Mahantango is in the lower sub-basin; Susquehanna Danville and Wyalusing Creek are in the middle sub-basin;

Susquehanna Chillisquaque, Pine and Loyalsock creeks are in the west branch sub-basin.

${ }^{2} \mathrm{BD}=$ below detection.

${ }^{3}$ Values in italics are estimated concentrations or values that are above the method detection limit but below the method quantitation limit. 
Supplementary Table 1 . Reporting limits ( $\mu \mathrm{g} / \mathrm{kg}$ wet weight) for organohalogenated chemicals measured in whole bodies of young-of-year Smallmouth Bass.

\begin{tabular}{|c|c|c|c|}
\hline Analyte & Reporting Limit & Analyte & $\begin{array}{c}\text { Reporting } \\
\text { Limit }\end{array}$ \\
\hline BDE congener 47 & 20.0 & Benfluralin & 0.8 \\
\hline BDE congener 66 & 0.5 & Chlorpyrifos & 0.5 \\
\hline BDE congener 71 & 1.0 & Cyfluthrin & 1.4 \\
\hline BDE congener 85 & 0.4 & DCPA (Dachal) & \\
\hline BDE congener 99 & 6.0 & Dieldrin & 2.0 \\
\hline BDE congener 100 & 1.4 & Fipronil & \\
\hline BDE congener 138 & 0.8 & Fipronil sulfide & 0.4 \\
\hline BDE congener 153 & 0.7 & Desulfinylfipronil & 1.0 \\
\hline BDE congener 154 & 0.7 & Hexachlorobenzene & 1.0 \\
\hline BDE congener 183 & 1.0 & Methyl triclosan & 10.0 \\
\hline PCB congener 101 & 5.0 & Octachlorostyrene & 4.0 \\
\hline PCB congener 110 & 3.0 & Oxyfluorfen & 15.0 \\
\hline PCB congener 118 & 2.5 & Pentabromotoluene & 6.0 \\
\hline PCB congener 138 & 2.5 & Pentachloronitrobenzene & 1.0 \\
\hline PCB congener 146 & 2.5 & Tefluthrin & 2.0 \\
\hline PCB congener 149 & 5.0 & Tetradifon & 2.0 \\
\hline PCB congener 151 & 2.5 & Trifluralin & 0.9 \\
\hline PCB congener 170 & 2.5 & $\alpha$-Endosulfan & 0.6 \\
\hline PCB congener 174 & 2.5 & $\beta$-Endosulfan & 0.6 \\
\hline PCB congener 177 & 2.5 & Endosulfan sulfate & 1.2 \\
\hline PCB congener 180 & 2.5 & $\lambda$-Cyhalothrin & 2.0 \\
\hline PCB congener 183 & 2.5 & $\mathrm{p}, \mathrm{p}^{\prime}-\mathrm{DDD}$ & 7.0 \\
\hline PCB congener 187 & 2.5 & $\mathrm{p}, \mathrm{p}^{\prime}-\mathrm{DDE}$ & 8.0 \\
\hline PCB congener 194 & 2.5 & $\mathrm{p}, \mathrm{p}^{\prime}-\mathrm{DDT}$ & 10.0 \\
\hline PCB congener 206 & 2.5 & trans-Chlordane & 0.5 \\
\hline 1,2-Bis $(2,4,6-$ & 0.9 & trans-Nonachlor & 0.7 \\
\hline tribromophenoxy)ethane & & & \\
\hline Dechlorane plus & 3.0 & cis-Chlordane & 1.0 \\
\hline \multirow[t]{2}{*}{ Pentachloroanisole } & 2.0 & cis-Nonachlor & 0.8 \\
\hline & & Oxychlordane & 5.0 \\
\hline
\end{tabular}


Supplementary Table 2. Reporting limits for current-use pesticides and pesticide degradates measured in whole bodies of young-of-year Smallmouth Bass.

\begin{tabular}{|c|c|c|c|}
\hline & Type $^{1}$ & $\mathrm{MDL}^{2}$ & $\mathrm{LOD}^{3}$ \\
\hline Alachlor & $\mathrm{H}$ & 1.6 & 0.5 \\
\hline Allethrin & $\mathrm{I}$ & 1.3 & 1.0 \\
\hline Atrazine & $\mathrm{H}$ & 1.1 & 0.5 \\
\hline Azinphos methyl & I & 1.9 & 1.0 \\
\hline Azoxystrobin & $\mathrm{F}$ & 0.8 & 0.5 \\
\hline Bifenthrin & $\mathrm{I}$ & 1.1 & 0.5 \\
\hline Boscalid & $\mathrm{F}$ & 0.9 & 0.5 \\
\hline Butylate & $\mathrm{H}$ & 0.7 & 1.0 \\
\hline Captan & $\mathrm{F}$ & 3.7 & 1.0 \\
\hline Carbaryl & I & 2.2 & 1.0 \\
\hline Carbofuran & I & 2.4 & 1.0 \\
\hline Chlorothalonil & $\mathrm{F}$ & 0.6 & 0.5 \\
\hline Chlorpyrifos & I & 0.9 & 0.5 \\
\hline Clomazone & $\mathrm{H}$ & 2.7 & 1.0 \\
\hline Cycloate & $\mathrm{H}$ & 0.6 & 1.0 \\
\hline Cyfluthrin & $\mathrm{I}$ & 1.6 & 1.0 \\
\hline Cyhalothrin & I & 0.8 & 0.5 \\
\hline Cypermethrin & I & 1.3 & 1.0 \\
\hline Cyproconazole & $\mathrm{F}$ & 1.4 & 0.5 \\
\hline Cyprodinil & $\mathrm{F}$ & 1.4 & 1.0 \\
\hline Dacthal & $\mathrm{H}$ & 1.8 & 0.5 \\
\hline Deltamethrin & I & 2.3 & 1.0 \\
\hline Diazinon & I & 1.2 & 1.0 \\
\hline Difenoconazole & $\mathrm{F}$ & 1.0 & 0.5 \\
\hline Dimethomorph & $\mathrm{F}$ & 1.4 & 1.0 \\
\hline Disulfoton & $\mathrm{I}$ & 1.6 & 1.0 \\
\hline EPTAM & $\mathrm{H}$ & 1.3 & 0.5 \\
\hline Esfenvalerate & $\mathrm{I}$ & 0.8 & 0.5 \\
\hline Ethalfluralin & $\mathrm{H}$ & 1.2 & 0.5 \\
\hline Etofenprox & I & 0.9 & 1.0 \\
\hline Famoxadone & $\mathrm{F}$ & 1.6 & 1.0 \\
\hline Fenarimol & $\mathrm{F}$ & 3.1 & 0.5 \\
\hline Fenbuconazole & $\mathrm{F}$ & 0.5 & 1.0 \\
\hline Fenhexamide & $\mathrm{F}$ & 1.6 & 1.0 \\
\hline Fenpropathrin & $\mathrm{I}$ & 2.0 & 1.0 \\
\hline Fipronil & $\mathrm{I}$ & 1.7 & 0.5 \\
\hline Fipronil desulfinyl & $\mathrm{D}$ & 1.1 & 0.5 \\
\hline Fipronil sulfide & $\mathrm{D}$ & 1.6 & 0.5 \\
\hline Fluazinam & $\mathrm{F}$ & 4.2 & 1.0 \\
\hline Fludioxinil & $\mathrm{F}$ & 2.3 & 1.0 \\
\hline Fluoxastrobin & $\mathrm{F}$ & 2.3 & 0.5 \\
\hline Flusilazole & $\mathrm{F}$ & 1.6 & 1.0 \\
\hline
\end{tabular}


Flutriafol

Hexazinone

Imazalil

Iprodione

Kresoxim-methyl

Malathion

Metalaxyl

Metconazole

Methidathion

Methoprene

Methyl parathion

Metolachlor

Molinate

Myclobutanil

Napropamide

Oxyflurofen

$p, p^{\prime}$-DDD

$p, p^{\prime}$-DDE

$p, p^{\prime}$-DDT

Pebulate

Pendimethalin

Pentachloronitrobenzene (PCNB)

Permethrin

Phenothrin

Phosmet

Prometon

Prometryn

Propanil

Propiconazole

Propyzamide

Pyraclostrobin

Pyrimethanil

Resemethrin

Simazine

Tebuconazole

Tefluthrin

Tetramethrin

Tetraconazole

t-Fluvalinate

Thiobencarb

Triadimefon

Triadimenol

Trifloxystrobin

Triflumizole

Trifluralin

Triticonazole
$\mathrm{H}$

$\mathrm{H}$

$\mathrm{F}$

$\mathrm{H}$

$\mathrm{H}$

D

D

I

$\mathrm{H}$

$\mathrm{H}$

F

I

I

I

$\mathrm{H}$

$\mathrm{H}$

$\mathrm{H}$

F

$\mathrm{H}$

F

F

I

$\mathrm{H}$

F

I

F

I

I

$\mathrm{H}$

$\mathrm{F}$

F

F

F

H

F

\section{7}

1.1

2.6

1.7

1.4

1.1

4.1

2.6

1.2

1.4

1.6

1.1

1.1

2.8

1.6

1.7

0.7

0.7

0.8

1.8

0.9

1.6

1.5

1.1

1.5

1.3

1.2

1.1

1.7

1.4

1.7

1.6

1.0

2.4

1.5

1.3

1.3

1.8

1.1

1.6

2.3

3.0

2.7

2.3

0.7

3.1
0.5

1.0

1.0

0.5

0.5

0.5

1.0

0.5

0.5

1.0

0.5

0.5

0.5

0.5

0.5

1.0

0.5

0.5

0.5

0.5

0.5

0.5

0.5

0.5

0.5

1.0

1.0

1.0

0.5

0.5

0.5

0.5

0.5

0.5

0.5

0.5

0.5

0.5

1.0

0.5

0.5

0.5

0.5

0.5

0.5

0.5 
Vinclozolin

F

F

2.8

3.1

0.5

Zoxamide

0.5

${ }^{1}$ Type $-\mathrm{D}=$ Degradate $; \mathrm{F}=$ Fungicide $; \mathrm{H}=$ Herbicide $; \mathrm{I}=$ Insecticide .

${ }^{2}$ Method detection limits ( $\mu \mathrm{g} / \mathrm{kg}$ wet weight)

${ }^{3}$ Instrumental limits of detection ( $\mu \mathrm{g} / \mathrm{kg}$ dry weight). 
Supplementary Table 3. Reporting limits (ng/L) for hormones and agricultural chemicals in passive sampler extracts reported as estimated water concentrations for the periods the samplers were deployed.

\begin{tabular}{|c|c|c|c|c|c|}
\hline Hormones & $\begin{array}{c}\mathrm{MDL}^{1} \\
\mathrm{ng} / \mathrm{L}\end{array}$ & $\begin{array}{c}\mathrm{MQL}^{2} \\
\mathrm{ng} / \mathrm{L}\end{array}$ & Agricultural Pesticides & $\begin{array}{c}\mathrm{MDL}^{1} \\
\mathrm{ng} / \mathrm{L}\end{array}$ & $\begin{array}{c}\mathrm{MQL}^{2} \\
\mathrm{ng} / \mathrm{L}\end{array}$ \\
\hline Bisphenol A & 2.40 & 12.0 & Trifluralin & 1.10 & 5.60 \\
\hline Diethylstilbestrol & 0.01 & 0.04 & Atraton & 0.11 & 0.56 \\
\hline Cis-Androsterone & 0.01 & 0.01 & Simazine & 0.26 & 1.30 \\
\hline Epitestosterone & 0.04 & 0.22 & Prometon & 0.13 & 0.63 \\
\hline Dihydrotestosterone & 0.04 & 0.22 & Atrazine & 0.24 & 1.20 \\
\hline 4-Androstene-3,17-dione & 0.01 & 0.04 & Desisoproylatrazine & 0.52 & 2.60 \\
\hline 11-Ketotestosterone & 0.01 & 0.03 & Desethylatrazine & 0.52 & 1.10 \\
\hline Testosterone & 0.01 & 0.04 & EPTC (thiocarbamate) & 0.94 & 4.70 \\
\hline 17- $\alpha$-estradiol & 0.01 & 0.05 & Propazine & 0.25 & 1.30 \\
\hline 17- $\beta$-estradiol & 0.01 & 0.05 & Terbuthylazine & 0.20 & 1.00 \\
\hline Estrone & 0.01 & 0.05 & Fonfos & 1.00 & 5.00 \\
\hline Equilin & 0.04 & 0.22 & Diazinon & 0.13 & 0.67 \\
\hline Estriol & 0.02 & 0.10 & Metribuzin & 0.34 & 1.70 \\
\hline Equilenin & 0.02 & 0.11 & Acetochlor & 0.14 & 0.71 \\
\hline 17 - $\alpha$-ethynylestradiol & 0.01 & 0.03 & Methyl parathion & 0.47 & 2.30 \\
\hline Norethindrone & 0.01 & 0.04 & Simetryn & 0.15 & 0.76 \\
\hline Mestranol & 0.01 & 0.05 & Alachlor & 0.17 & 0.85 \\
\hline Progesterone & 0.03 & 0.13 & Ametryn & 0.17 & 0.84 \\
\hline 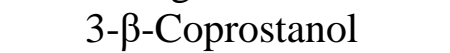 & 2.20 & 11.0 & Prometryn & 0.19 & 0.96 \\
\hline \multirow[t]{7}{*}{ Cholesterol } & 5.00 & 25.0 & Terbutryn & 0.18 & 0.88 \\
\hline & & & Malathion & 11.0 & 57.0 \\
\hline & & & Metolachlor & 0.32 & 0.97 \\
\hline & & & Chlorpyrifos & 1.10 & 5.40 \\
\hline & & & Dacthal & 3.70 & 10.0 \\
\hline & & & Pendimethalin & 0.22 & 1.10 \\
\hline & & & Fipronil & 1.10 & 5.50 \\
\hline
\end{tabular}

${ }^{1} \mathrm{MDL}=$ method detection limit

${ }^{2} \mathrm{MQL}=$ method quantitation limit 


\title{
Chapter Three: The Use of Fluorescence In Situ Hybridization (FISH) for Identification of Coinfections in Young-of-the-Year Smallmouth Bass from the Susquehanna River Drainage, Pennsylvania, USA
}

\begin{abstract}
During ongoing fish health assessments of young-of-the-year smallmouth bass (YOY SMB) in the Susquehanna River drainage, a high prevalence of the myxozoan Myxobolus inornatus has been observed infecting the connective tissue of the muscle below the skin. In some instances, shallow infections cause breaks in the skin which could increase the chance of secondary bacterial infections, such as Flavobacterium spp. and Aeromonas spp. In order to determine the prevalence of these coinfections, a fluorescence in situ hybridization (FISH) assay was developed. With FISH, 75\% of YOY SMB exhibited M. inornatus infections, 10\% had Aeromonas spp. infections, and 5\% had Flavobacterium spp. infections. Only 3\% had coinfections with both bacterial species and M. inornatus. The results of this study show a low rate of coinfections of Flavobacterium spp. and/or Aeromonas spp. with M. inornatus. The high prevalence of M. inornatus suggests this may be a primary pathogen associated with YOY mortality. Future work should be directed toward understanding pathogenesis, possible effects on disease resistance and interactions with other bacterial and viral pathogens.
\end{abstract}

\section{Introduction}

Fish health assessments of young-of-the-year smallmouth bass (YOY SMB) Micropterus dolomieu in the Susquehanna River drainage in Pennsylvania have been ongoing for over a decade. Observations of YOY SMB mortalities were first documented in the summer of 2005 
and have varied in prevalence, spatially, and temporally, in the years since. The magnitude of reoccurring disease in YOY SMB has been observed at the population level, with a significant decrease in age-1 SMB and a shift to larger and older fish (Smith et al. 2015). Symptoms of disease have included skin lesions, systemic infections, parasites, and largemouth bass virus (Smith et al. 2015; Walsh et al. 2012; Walsh et al. 2018). Bacterial isolates from skin lesions have included Flavobacterium columnare and multiple Aeromonas spp. (Starliper et al., 2013). Abiotic and biotic factors such as water quality, contaminants of emerging concern, temperature fluctuations, and pathogens have all been proposed initiators of disease (Chaplin et al. 2009; Smith et al. 2005; Walsh et al. 2018); however, it is likely the cumulative effects of these environmental stressors that present the greatest risk. In a study by Walsh et al. (2018), numerous YOY SMB were found to have coinfections of parasites, skin lesions, and systemic infections.

One of the most frequently observed parasites infecting YOY SMB is the myxozoan Myxobolus inornatus. This myxozoan infects the connective tissue of the muscle and plasmodium are often found below the dermis of the skin; however, large plasmodia can rupture the epidermis (Walsh et al. 2012). Previous studies have shown that primary infections with parasites that cause skin damage can lead to higher rates of subsequent infections with pathogenic bacteria (Esch et al. 1976; Roon et al. 2015). For example, rainbow trout Oncorhynchus mykiss infected with an ectoparasite showed susceptibility to increased infections and mortality when co-infected with Flavobacterium columnare (Bandilla et al. 2006). However, it is yet to be determined if $M$. inornatus is associated with bacterial coinfections in YOY SMB. 
One method that can be used to detect coinfections of $M$. inornatus and bacteria is fluorescence in situ hybridization (FISH). This method has been used in multiple fish studies for pathogen detection and identification (Grésoviac et al. 2007; Holzer et al. 2003; McCarthy et al. 2008; Morris et al. 1999; Strepparava et al. 2012). In situ hybridization allows for the detection and visualization of DNA and RNA within tissue sections (Cassidy and Jones 2014). With FISH, probes can be labeled with different fluorescence tags to detect multiple targets in one tissue sample (Shah et al. 2017). Performing FISH with probes designed to hybridize to bacteria, such as Flavobacterium spp. and Aeromonas spp., can help determine whether M. inornatus is associated with these subsequent bacterial infections.

The objective of this study was to determine whether YOY SMB infected with $M$. inornatus have a greater prevalence of coinfections with Flavobacterium spp. and/or Aeromonas spp. In order to determine the prevalence of these coinfections, a dual-color FISH assay was developed. Young-of-the-year SMB were sampled from multiple sites within the Susquehanna River drainage and histologically examined for the presence of M. inornatus. Samples for FISH were selected based on histopathological findings and used to determine the prevalence of coinfections. Addressing this issue will help shed light on the effects M. inornatus has on coinfections with these virulent bacteria and whether it should be considered a serious parasite of disease in YOY SMB.

\section{Methods}

Fish Sampling and Histology

In 2014, approximately 20 YOY SMB were sampled from multiple sites in the Susquehanna River drainage and two out-of-basin sites with backpack electroshocking 
equipment (Fig. 1). Fish were euthanized with a lethal dose $(350 \mathrm{mg} / \mathrm{L})$ of tricaine methanesulfonate (MS-222, Syndel USA, Ferndale, Washington), a slit made to open the abdominal cavity, and whole fish were placed in Z-Fix ${ }^{\mathrm{TM}}$ (Anatech LTD, Battle Creek, Michigan) or PAXgene® (PreAnalytiX, Switzerland). The samples were brought back to the histology laboratory and whole bodies were decalcified with EDTA and routinely processed for microscopic examination (Luna 1992). Two-longitudinal sections of the head and up to six dorsal, transverse sections of the body were placed in cassettes, dehydrated in graded concentrations of alcohol, embedded into paraffin, sectioned at $5 \mu \mathrm{m}$ and stained with hematoxylin and eosin.

\section{Fluorescence In Situ Hybridization}

The following protocol was used for dual color FISH to visualize coinfections of $M$. inornatus and/or Flavobacterium spp. and Aeromonas spp. The same sections that were used for histopathological analyses were re-cut at 5um, placed on poly-L-lysine coated slides and left unstained. Sections were deparaffinized with three changes of Pro-Par (Anatech Ltd., Battle Creek, Michigan) for 5 min each and rehydrated with a graded ethanol series consisting of 100, $95,80,70$, and $50 \%$ for 3 min each and rinsed in PBS three times for 1 min each. Incubation in $0.2 \mathrm{~N} \mathrm{HCl}$ was conducted for $20 \mathrm{~min}$ at room temperature as an added protein extraction and target hydrolysis step and was followed by a rinse in PBS for $1 \mathrm{~min}$. Tissues were permeabilized in Proteinase K (Sigma-Aldrich, St. Louis, Missouri) at a concentration of $100 \mu \mathrm{g} / \mathrm{mL}$ in PBS for $10 \mathrm{~min}$ at $37^{\circ} \mathrm{C}$; however, this step was excluded for PAXgene fixed tissues. Following Proteinase $\mathrm{K}$ incubation, sections were rinsed twice in $2 \%$ glycine in PBS for 3 min each and rinsed in PBS for 5 min. A hybridization solution consisting of 50\% deionized Formamide, 20\% 
4X standard saline citrate (SSC; 20X SSC $=3.00 \mathrm{M} \mathrm{NaCl}, 0.34 \mathrm{M}$ sodium citrate, $\mathrm{pH} 7.0$ ), $5 \%$ heat-denatured single strand salmon sperm DNA (at $10 \mathrm{mg} / \mathrm{mL}$; Sigma-Aldrich, St. Louis, Missouri), 20\% dextran sulfate (50\%, v:v), and 2\% 50X Denhardt's solution was added to each slide with a probe concentration of $10 \mathrm{ng} / \mu \mathrm{L}$ and a Hybriwell ${ }^{\mathrm{TM}}$ coverslip (Grace Bio-Labs, Bend, Oregon) was applied. Probes were labeled with Alexa Fluor ${ }^{\circledR}$ dyes on the 5'-end (Integrated DNA Technologies, San Diego, California; Table 2). Tissue and probe were denatured at $95^{\circ} \mathrm{C}$ for $10 \mathrm{~min}$ and then placed in an InSlide Out ${ }^{\mathrm{TM}}$ hybridization oven (Boekel, Feasterville, Pennsylvania) overnight at $40^{\circ} \mathrm{C}$. The following day, the slides were washed in $4 \mathrm{X}$ $\mathrm{SSC}$ for $10 \mathrm{~min}$ at room temperature, twice in $2 \mathrm{X} \mathrm{SSC}$ for $10 \mathrm{~min}$ at $37^{\circ} \mathrm{C}$, and twice in $0.5 \mathrm{X}$ SSC for $5 \mathrm{~min}$ at room temperature. After a wash in PBS for $10 \mathrm{~min}$ at room temperature, the slides were counterstained in Sudan Black B (1\% in 70\% ETOH) for 5 min to reduce autofluorescence. Following staining, the slides were rinsed three times with PBS for 3 min each and a glass coverslip was mounted with ProLong® Diamond Antifade Mountant (Life Technologies, Eugene, Oregon).

Starliper et al. (2013) identified multiple Aeromonas spp. in YOY SMB, therefore a generic probe which targeted multiple species was used. However, only $F$. columnare was tested for in this study, and since other species could be present, a generic probe was also used for Flavobacterium spp. Probes were created with previously published sequences (Table 1) and purchased from IDT DNA (San Diego, California) with AlexaFluor tags on the 5' end. Generic probes targeting the $16 \mathrm{~S}$ rRNA region were developed to hybridize to almost all Aeromonas spp. (Kämpfer et al. 1996) and Flavobacterium spp (Strepparava et al. 2012). The probe for $M$. inornatus was species specific (Walsh et al. 2012) and a NCBI Blast showed no similarity to any other myxozoan species. Positive controls of fish infected with M. inornatus, Flavobacterium 
columnare, Aeromonas hyrophila, and Aeromonas sobria were used to determine probe efficiency and specificity. The probe developed for M. inornatus was tested for specificity using YOY SMB infected with M. inornatus and smallmouth bass infected with two other myxozoans (one that infects the gills and one that infects the kidney). Tissue samples of YOY channel catfish Ictalurus punctatus spleen, liver, head kidney, and skin were provided by Benjamin LaFrentz from the USDA Aquatic Animal Health Research Laboratory (Auburn, Alabama). These catfish were experimentally challenged by immersion with Flavobacterium columnare and were used to test the Flavobacterium spp. probe. Tissue samples of goldfish Carassius auratus spleen and kidney and koi Cyprinus carpio skin were provided by John Hawke from the Department of Pathobiological Sciences at Louisiana State University School of Veterinary Medicine (Baton Rouge, Lousiana). These samples served as positive controls for testing the Aeromonas spp. probe. The goldfish had a primary cyprinid herpesvirus 2 (CyHV-2) infection which was subsequently colonized by Aeromonas hydrophila. The koi presented multiple lesions along the lateral line determined to be infected with Aeromonas sobria.

A Pearson correlation analysis was done to determine if the presence of $M$. inornatus correlated with the presence of Flavobacterium spp. or Aeromonas spp.

\section{Results}

Fish Sampling and Histopathology

A total of 409 YOY SMB were sampled in 2014 from 20 sites in the Susquehanna River drainage and two out-of-basin-sites. With histopathology, 145 (145/409; 35\%) YOY SMB had M. inornatus infections in various areas of the body, including the connective tissue below the dorsal and caudal fins, deep in the connective tissue of the muscle, and in areas of the operculum. 
Overall, out-of-basin sites had a lower prevalence of $M$. inornatus than the four subbasins of the Susquehanna River drainage (Table 2). Ninety-six fish were chosen to use in the FISH assay to determine the prevalence of coinfections of M. inornatus, Flavobacterium spp., and Aeromonas spp. These fish were chosen if $M$. inornatus infections were uncertain with histopathology (if only inflammation was observed; Fig. 2A), if there was a skin lesion (Fig. 2B), or if there were heavy or severe infections of $M$. inornatus (Fig. 2C). These fish were from Pine Creek, Penns Creek, West Branch Mahantango Creek, Susquehanna River at Mahantango Creek, Bald Eagle Creek, Loyalsock Creek, and West Branch Susquehanna River at Jersey Shore (Fig.1).

Histologically, skin lesions were determined by the presence of epidermal degeneration and necrosis with inflammatory cell infiltration. In some instances, these lesions were observed penetrating into the muscle. Grossly, lesions varied in appearance, with some that looked like raised areas (Fig. 3A), areas of epidermal erosion with muscle exposure (Figs. 3A \& B), areas of erosion down to the bone (Fig. 3C), and pale areas (Figs. 3B \& C).

\section{Fluorescence In Situ Hybridization}

Positive control samples showed that the fluorescently labeled probes for Flavobacterium spp., Aeromonas spp., and M. inornatus successfully hybridized to their targets. Of the YOY SMB analyzed with FISH, five exhibited Flavobacterium spp. infections (5/96; 5\%), 10 exhibited Aeromonas spp. infections (10/96; 10\%), and 72 (72/96; 75\%) exhibited M. inornatus infections (Figs. 3A-C). Coinfections of Flavobacterium spp. and M. inornatus were observed in 4 fish (4/96; 4\%; Fig. 4), three fish had coinfections with Aeromonas spp. and M. inornatus (3/96; 3\%), one fish had a co-infection of Aeromonas spp. and Flavobacterium spp. (1/96; 1\%), and three fish had coinfections of all three pathogens $(3 / 96 ; 3.13 \%)$. Finally, there were six fish 
$(6 / 96 ; 6 \%)$ that were positive for M. inornatus in areas of inflammation that did not present visible cysts or spores with routine histology. The results of the Pearson Correlation analysis showed that the presence of $M$. inornatus was not correlated with the presence of Flavobacterium spp. $(r=0.11)$ or Aeromonas spp. $(r=-0.11)$.

Location of bacterial infections varied, with a majority of Aeromonas spp. infections observed in the gut $(9 / 10 ; 90 \%)$ and all Flavobacterium spp. infections observed in skin lesions (5/5; 100\%). Starliper et al. (2013) isolated Aeromonas veronii bv. sobria and Flavobacterium columnare from skin lesions and the anterior kidney of YOY SMB. Both Aeromonas spp. and Flavobacterium spp. are capable of infecting fish externally and internally (Camus et al. 1998; Loch and Faisal 2015) and have been found in the intestinal microflora of normal, healthy juvenile fish (Ring $\varnothing$ and Birkbeck 1999). In this study Flavobacterium spp. were always associated with skin lesions and not observed in areas of normal skin or the gut. However, Aeromonas spp. observed in the lumen of the gut were not associated with intestinal lesions.

\section{Discussion}

In fish, the mucosal layer of skin plays an important role in immune function and is the first line of defense against pathogens. However, when this layer is damaged fish can be vulnerable to subsequent infections (Esteban 2012). Prior to this study, the effect of the myxozoan $M$. inornatus on secondary bacterial infections was unknown. Therefore, the goal was to determine whether $M$. inornatus infections increased the likelihood of bacterial coinfections with Flavobacterium spp. and/or Aeromonas spp. With the use of a FISH assay incorporating generic Flavobacterium spp. and Aeromonas spp. probes, coinfections with M. inornatus were examined. With FISH, Flavobacterium spp. were observed in 5\% of fish, Aeromonas spp. were 
observed in $10 \%$ of fish, and M. inornatus in $75 \%$ of fish. Only $3 \%$ of YOY SMB had coinfections of $M$. inornatus with both types of bacteria. Although coinfections of bacteria and M. inornatus did occur, they were not always directly associated with $M$. inornatus nor were they correlated with the presence of $M$. inornatus.

There are many species of myxozoan parasites that are primary pathogens of fish (Lom and Dyková 2006) and are more pathogenic to juvenile fish (Ahmad and Kaur 2016; Bolick et al. 2013; Foott et al. 2007; Ryce et al. 2005). Also, the effects of myxozoan infections can be exacerbated by other factors. The myxozoan Myxobolus cerebralis, for example, is associated with mortality in fingerling rainbow trout Oncorhynchus mykiss and mortality can increase by co-exposure to high water temperatures (Schisler et al. 2000). In fish, the pathogenic effects of myxozoans varies and is dependent upon environmental factors (such as temperature and water quality), host immunocompetence, the species of myxozoan, and the target organ of infection (Gómez et al. 2014). Young-of-the-year SMB in the Susquehanna River drainage are exposed to low dissolved oxygen, elevated temperatures (Chaplin et al. 2009) and contaminants in the water (PADEP 2016), especially during the summer. Thus, it is possible that environmental conditions may contribute to the effects of $M$. inornatus resulting in a more primary role of disease in YOY SMB with or without secondary infections. Additionally, histopathology revealed M. inornatus infections were higher in YOY SMB from the Susquehanna River drainage when compared to YOY SMB collected from out-of-basin sites (Table 2), similar to previous findings (Walsh et al. 2018). Coinfections were also previously found to be greater in fish from the Susquehanna River drainage sites. Therefore, in addition to poor environmental conditions, the role of $M$. inornatus as a primary stressor in coinfections may warrent further investigation. 
The use of FISH in this assay provided a way to identify and visualize bacterial and $M$. inornatus coinfections that may not have been identified with routine culture techniques. The Aeromonas spp. infections identified with FISH were located within the lumen of the gut, an area where bacteria are not routinely cultured. Additionally, FISH allowed a direct association to be made between positive samples and histopathological alterations. For example, with routine culture, only the surface of the skin or a skin lesion is swabbed for bacteriology; however, FISH allowed for visualization of the bacteria invading tissue below the epidermal surface. In YOY SMB, Flavobacterium spp. infection generally occurred in and around skin lesions and Aeromonas spp. were most often observed in the lumen of the gut with little to no associated pathology. FISH was also successful for identifying samples positive for M. inornatus in areas where only inflammation was observed with histopathology.

In many studies, bacterial infections have been documented secondarily after primary infections with parasites which cause skin erosion (Esch et al. 1976; Pylkkö et al. 2006; Xu et al. 2012; Xu et al. 2014; Zhang et al. 2015). Myxozoans are known to infect fish hosts by invasion of the mucosal layer and skin (Gómez et al. 2014) and can therefore create areas for secondary infections to occur. Additionally, the risk of infection can be greater in juvenile fish since their adaptive immune response is underdeveloped (Uribe et al. 2011; Zapata et al. 2006). Unlike the findings of Starliper et al. (2013) where bacteria were cultured from skin lesions of YOY SMB in the Susquehanna River drainage in 2010-2011, the number of bacterial infections was much lower in this study. This could be attributable to study design, with the goal of Starliper et al. (2013) to target fish with visible lesions and this study targeting both normal and diseased fish. The most predominant bacterial species identified in Starliper et al. (2013) were Flavobacterium columnare and Aeromonas veronii bv. sobria. Bacterial coinfections could also be lower 
because YOY SMB with these types of infections may already be deceased. This could contribute to the lower incidence of coinfections observed between these pathogenic bacteria and M. inornatus.

Flavobacterium spp. and Aeromonas spp. are well known for their opportunistic behavior and tendency to infect immunosuppressed fish (Noga 1996). They are able to withstand warm water temperatures during the summer (coinciding with YOY SMB development), are ubiquitous, and oftentimes do not pose a threat to healthy fish (Loch and Faisal 2015; Noga 1996). Fish exposed to chronic stressors, such as poor water quality, contaminants, or parasites are more likely to have an impaired immune response (Barton 2002). Young-of-the-year SMB from the Susquehanna River drainage have been shown to have multiple coinfections of parasites, skin lesions, systemic infections, and contaminants accumulated in their tissues (Walsh et al. 2018). Hence, these types of physical stressors can impact immune function within a population (Tort 2011). Although FISH did not identify a high prevalence of YOY SMB infected with Flavobacterium spp. and Aeromonas spp., there could be other bacteria associated with these lesions that were not tested for in this study.

A lack of coinfections of M. inornatus with Flavobacterium spp. or Aeromonas spp., may be explained by other factors which affect YOY SMB. As previously mentioned, many YOY SMB had coinfections of parasites and pathogens (Walsh et al. 2018) in addition to M. inornatus, Flavobacterium spp., and Aeromonas spp. These infections included helminth parasites (such as digenetic trematodes and cestodes), which are known to increase the susceptibility of subsequent bacterial infections (Ezenwa and Jolles 2011). Digenetic trematodes can infect fish by penetrating the skin and migrating to target organs for development (Lane and Morris 2010). Digenetic trematodes were observed in YOY SMB muscle and internal organs (kidneys, liver, 
and spleen; Walsh et al. 2018) and may also cause skin perforations similar to M. inornatus. Thus, skin lesions with secondary bacterial infections could result. Additionally, cestodes were observed in the gut of many YOY SMB. This was also the location where the majority of Aeromonas spp. infections were observed. The procercoids of Proteocephalus ambloplitis, the smallmouth bass tapeworm, often burrow through the gut wall to migrate to other tissues (Allison 1941). Similar to perforations in the skin, this could potentiate the risk of Aeromonas spp. to invade the surrounding mesentery.

To conclude, the FISH results showed that infections of $M$. inornatus in YOY SMB can be associated with subsequent infections of Flavobacterium spp. and/or Aeromonas spp. However, the high prevalence of $M$. inornatus infections suggest this may be a primary pathogen for YOY smallmouth bass. It was previously speculated that perforations in the skin caused by M. inornatus may increase the rate of infection of infectious bacteria. It cannot be ruled out however, that other species of bacteria may have been present that were not tested for in this study. Starliper et al. (2013) identified other bacterial species from YOY SMB lesions, including Plesiomonas shigelloides, Citrobacter sp., and Pseudomonas sp. Furthermore, pathogens such as LMBV should be examined. It was shown in a laboratory exposure study of LMBV that YOY SMB developed skin lesions associated with the virus (Boonthai et al. 2018). Future work with FISH can be used to identify other types of coinfections, such as helminth parasites or LMBV, and to determine whether other bacterial species are associated with $M$. inornatus. It is important to better understand the pathogenicity of this myxozoan and the role it plays in disease of YOY SMB in the Susquehanna River drainage in order to mitigate the effects of this parasite.

\section{References}


Allison, L.N. 1941. Proteocephalus ambloplitis, the bass tapeworm, it's life history, importance to bass culture and its control. Fisheries Research Report 714. https://quod.lib.umich.edu/f/fishery/AAG2862.0714.001?rgn=main;view=fulltext.

Bandilla, M., E.T. Valtonen, L.-R. Suomalainen, P.J. Aphalo, T. Hakalahti. 2006. A link between ectoparasite infection and susceptibility to bacterial disease in rainbow trout. International Journal for Parasitology 36: 987-991.

Barton, B.A. 2002. Stress in fishes: a diversity of responses with particular reference to changes in circulating corticosteroids. Integrative and Comparative Biology 42: 517-525.

Bolick, A., K. True, and J. Foott. 2013. Myxosporean parasite (Ceratomyxa shasta and Parvicapsula minibicornis) annual prevalence of infection in Klamath River basin juvenile chinook salmon, April-August 2013. U.S. Fish \& Wildlife Service California Nevada Fish Health Center, Anderson, CA. http://www.fws.gov/canvfhc/reports.asp.

Boonthai, T., T.P. Loch, C.J. Yamashita, G.D. Smith, A.D. Winters, M. Kiupel, T.O. Brenden, and M. Faisal. 2018. Laboratory investigation into the role of largemouth bass (Ranavirus Iridoviridae) in smallmouth bass mortality events in Pennsylvania rivers. BMC Veterinary Research 14: 62.

Camus, A.C., R.M. Durborow, W.G. Hemstreet, R.L. Thune, and J.P. Hawke. 1998. Aeromonas bacterial infections - motile Aeromonad septicemia. Southern Regional Aquaculture Center 478: 1-4.

Cassidy, A. and J. Jones. 2014. Developments in in situ hybridization. Methods 70:39-45.

Esch, G.W., T.C. Hazen, R.V. Dimock, Jr., and J. W. Gibbons. 1976. Thermal effluent and the epizootiology of the ciliate Epistylis and the bacterium Aeromonas in association with centrarchid fish. Transactions of the American Microscopical Society 95: 687-693.

Esteban, M.Á. 2012. An overview of the immunological defenses in fish skin. International Scholarly Research Network 2012: 1-29.

Ezenwa, V.O., and A.E. Jolles. 2011. From host immunity to pathogen invasion: the effects of helminth coinfection on the dynamics of microparasites. Integrative and Comparative Biology 51: 540-551.

Foott, J.S., R. Stone, and K. Nichols. 2007. Proliferative kidney disease (Tetracapsuloides bryosalmonae) in Merced River hatcher juvenile chinook salmon: mortality and performance impairment in 2005 smolts. California Fish and Game 93: 57-76.

Frickmann, H., A.E. Zautner, A. Moter, J. Kikhney, R.M. Hagen, H. Stender, and S. Poppert. 2017. Fluorescence in situ hybridization (FISH) in the microbiological diagnostic routine laboratory: a review. Critical Reviews in Microbiology 43: 263-293. 
Gómez, D., J. Bartholomew, and J.O. Sunyer. 2014. Biology and mucosal immunity to myxozoans. Developmental and Comparative Immunology 43: 243-256.

Grésoviac, S.J., D.V. Baxa, C.P. Vivarés, and R.P. Hedrick. 2007. Detection of the intramuscular microsporidium Nucleospora salmonis in naturally and experimentally exposed chinook salmon Oncorhynchus tshawytscha by in situ hybridization. Parasitology Research 101: 1257-1264.

Holzer, A.S., C. Sommerville, and R. Wootten. 2003. Tracing the route of Sphaerospora truttae from the entry locus to the target organ of the host, Salmo salar L., using an optimized and specific in situ hybridization technique. Journal of Fish Diseases 26: 647-655.

Jensen H.E., L.K. Jensen, K. Barington, S.E. Pors, T. Bjarnsholt, M. Boye. 2015. Fluorescence In Situ Hybridization for the Tissue Detection of Bacterial Pathogens Associated with Porcine Infections. In: Cunha M., Inácio J. (eds) Veterinary Infection Biology: Molecular Diagnostics and High-Throughput Strategies. Methods in Molecular Biology (Methods and Protocols), vol 1247. Humana Press, New York, NY.

Kämpfer, P., R. Erhart, C. Beimfohr, J. Böhringer, M. Wagner, and R. Amann. 1996. Characterization of bacterial communities from activated sludge: culture-dependent numerical identification versus in situ identification using group- and genus-specific rRNA-targeted oligonucleotide probes. Microbial Ecology 32: 101-121.

Lane, R.L. and J.E. Morris. Biology, prevention, and effects of common grubs (digenetic trematodes) in freshwater fish. 2010. NCRAC Technical Bulletins 14.

Loch, T.P. and M. Faisal. 2015. Emerging Flavobacterial infections in fish: a review. Journal of Advanced Research 6: 283-300.

Lom, J. and I. Dyková. 2006. Myxozoan genera: definition and notes on taxonomy, life-cycle terminology and pathogenic species. Folia Parasitologica 53: 1-36.

Luna, L. 1992. Histopathologic methods and color atlas of special stains and tissue artifacts. American Histolabs, Inc., Gaithersburg, Maryland.

McCarthy, Ú.M., K.L. Urquhart, and I.R. Bricknell. 2008. An improved in situ hybridization method for the detection of fish pathogens. Journal of Fish Diseases 31: 669-677.

Morris, D.J., A. Adams, and R.H. Richards. 1999. Journal of Fish Diseases 22: 161-163.

Noga, E.J. 1996. Fish Disease: Diagnosis and Treatment. St. Louis, Missouri: Mosby-Year Book, Inc. 
Pylkkö, P., L.-R., Suomalainen, M. Tiirola, and E.T. Valtonen. 2006. Evidence of enhanced bacterial invasion during Diplostomum spathaceum infection in European grayling, Thymallus thymallus (L.). Journal of Fish Diseases 29: 79-86.

Ringø, E. and T.H. Birkbeck. 1999. Intestinal microflora of fish larvae and fry. Aquaculture Research 30: 73-93.

Roon, S.R., J.D. Alexander, K.C. Jacobson, and J.L. Bartholomew. 2015. Effect of Nanophyetus salmincola and bacterial co-infection on mortality of juvenile chinook salmon. Journal of Aquatic Animal Health 27: 209-216.

Ryce, E.K.N., A.V. Zale, E. MacConnell, and M. Nelson. 2005. Effects of fish age versus size on the development of whirling disease in rainbow trout. Diseases of Aquatic Organisms 63: 69-76.

Shah, J., A. Poruri, O. Mark, U. Khadilka, F. Mohring, R.W. Moon, and R. Ramasamy. 2017. A dual color fluorescence in situ hybridization (FISH) assay for identifying the zoonotic malaria parasite Plasmodium knowlesi with a potential application for the specific diagnosis of knowlesi malaria in peripheral-level laboratories of Southeast Asia. Parasites \& Vectors 10: 342.

Smith, G.D., V.S. Blazer, H.L. Walsh, L.R. Iwanowicz, and A.J. Sperry. 2015. The effects of disease-related mortality of young-of-the-year smallmouth bass on population characteristics in the Susquehanna River Basin, Pennsylvania and potential implications to conservation of black bass diversity. American Fisheries Symposium 82: 319-332.

Starliper, C., V.S. Blazer, L.R. Iwanowicz and H.L. Walsh. 2013. Bacterial isolates in diseased fishes, primarily smallmouth bass (Micropterus dolomieu), within the Chesapeake Bay drainage in 2009-2011. Proceedings of the West Virginia Academy of Science 85:18-32.

Strepparava, N., T. Wahli, H. Segner, B. Polli, and O. Petrini. 2012. Fluorescent in situ hybridization: a new tool for the direct identification and detection of $F$. phychrophilum. PLoS ONE 7: e49280.

Tort, L. 2011. Stress and immune modulation in fish. Developmental and Comparative Immunology 35: 1366-1375.

Uribe, C., H. Folch, R. Enriquez, and G. Moran. 2011. Innate and adaptive immunity in teleost fish: a review. Veterinarni Medicina 56: 486-503.

Walsh, H.L., V.S. Blazer, L.R. Iwanowicz, and G. Smith. 2012. A redescription of Myxobolus inornatus from young-of-the-year smallmouth bass (Micropterus dolomieu). Journal of Parasitology 98: 1236-1242. 
Walsh, H.L., V.S. Blazer, G. D. Smith, M. Lookenbill, D.A. Alvarez, and K.L. Smalling. 2018. Risk factors associated with mortality of Age- 0 smallmouth bass in the Susquehanna River Basin, Pennsylvania. Journal of Aquatic Animal Health 30:65-80.

Xu, D.-H., C.A. Shoemaker, M.L. Martins, J.W. Pridgeon, and P.H. Klesius. 2012. Enhanced susceptibility of channel catfish to the bacterium Edwardsiella ictaluri after parasitism by Ichthyophthirius multifiliis. Veterinary Microbiology 158: 216-219.

Xu, D.H., C.A. Shoemaker, and B.R. LaFrentz. 2014. Enhanced susceptibility of hybrid tilapia to Flavobacterium columnare after parasitism by Ichthyophthirius multifiliis. Aquaculture 430: 44-49.

Zapata, A., B. Diez, T. Cejalvo, C.G. Frías, and A. Cortés. 2006. Ontogeny of the immune system of fish. Fish and Shellfish Immunology 20: 126-136.

Zhang, C., D.-L. Li, C. Chi, F. Ling, and G.-X. Wang. 2015. Dactylogyrus intermedius parasitism enhances Flavobacterium columnare invasion and alters immune-related gene expression in Carassius auratus. Diseases of Aquatic Organisms 116: 11-21. 


\section{Figures}

Figure 1. Map of sites where young-of-the-year smallmouth bass were collected within the Susquehanna River drainage and two out-of-basin sites in 2014.

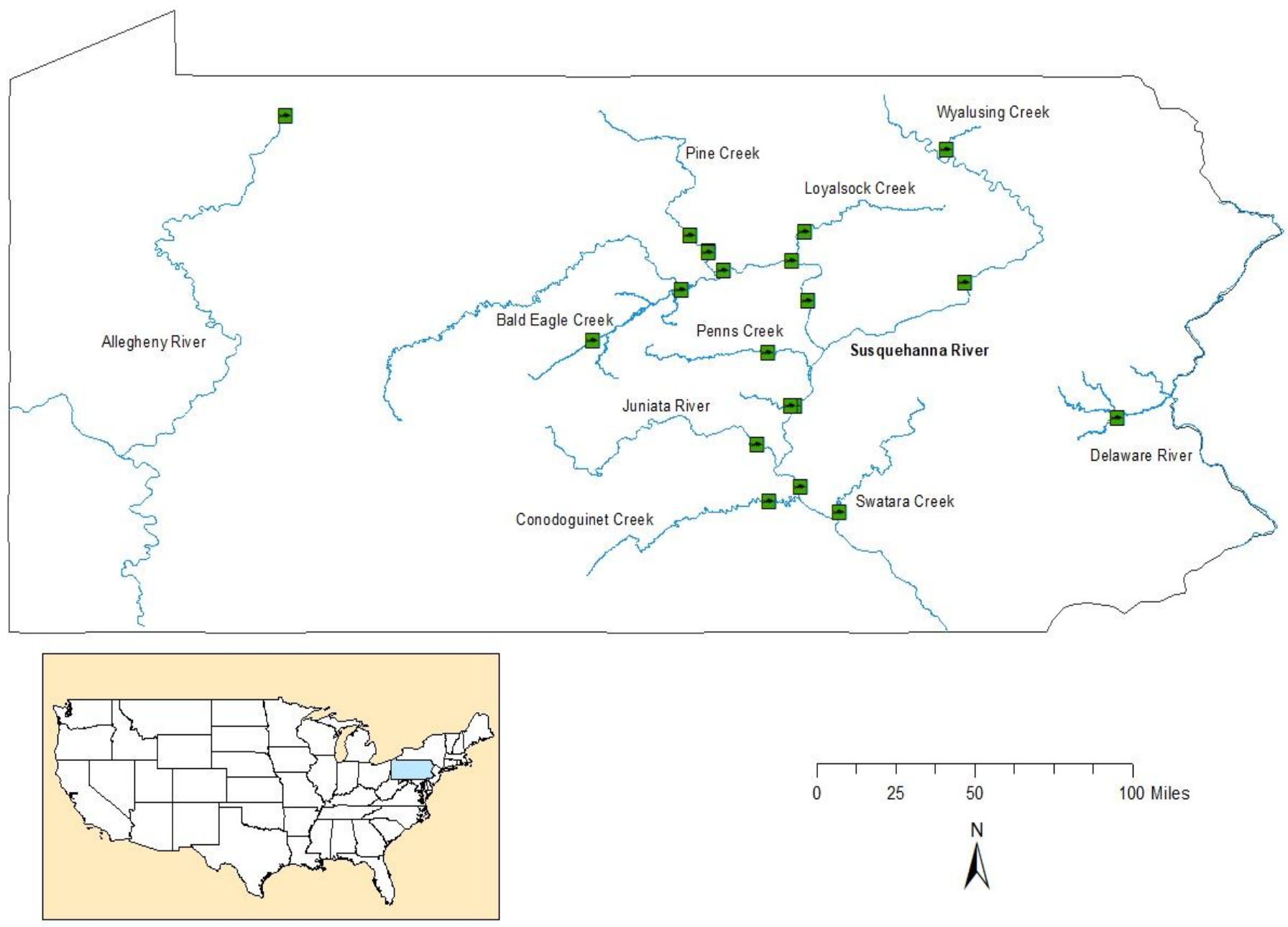


Figure 2. Samples of young-of-the-year smallmouth bass chosen to include for the FISH assay were based on histopathology results. Samples were included if A) areas of inflammation were observed that could be associated with M. inornatus, B) a skin lesion was observed with spreading necrosis, degeneration, and inflammation into the epidermal layers and surrounding muscle, or C) multiple or severe infections of M. inornatus were observed.
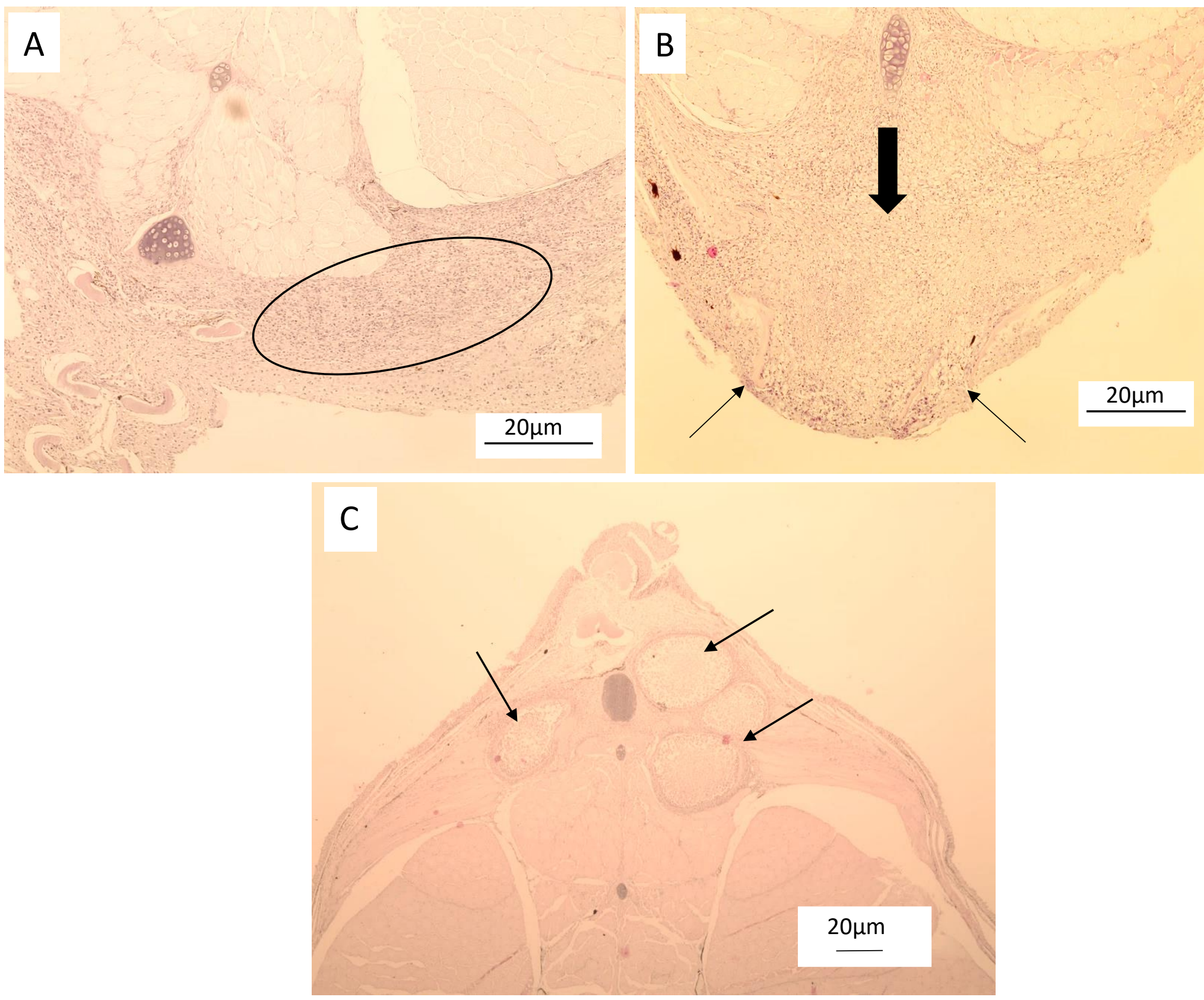
Figure 3. Various types of gross lesions observed on young-of-the-year smallmouth bass in the Susquehanna River drainage. A) Spreading skin lesions with necrotic centers exposing the underlying dermis (arrows) and a creamy white cyst at the base of the caudal fin (circle) caused by $M$. inornatus. B) Top fish displaying a more advanced spreading skin lesion with epidermal, dermal, and muscle necrosis and degeneration and hemorrhaging (bold arrow) and the bottom fish displaying focal areas of epidermal degeneration (thin arrows). C) Early stage spreading lesion with epidermal degeneration (thin arrows) and a red-eroded lesion at the base of caudal fin with necrosis exposing bone at the base of the caudal fin (bold arrow).
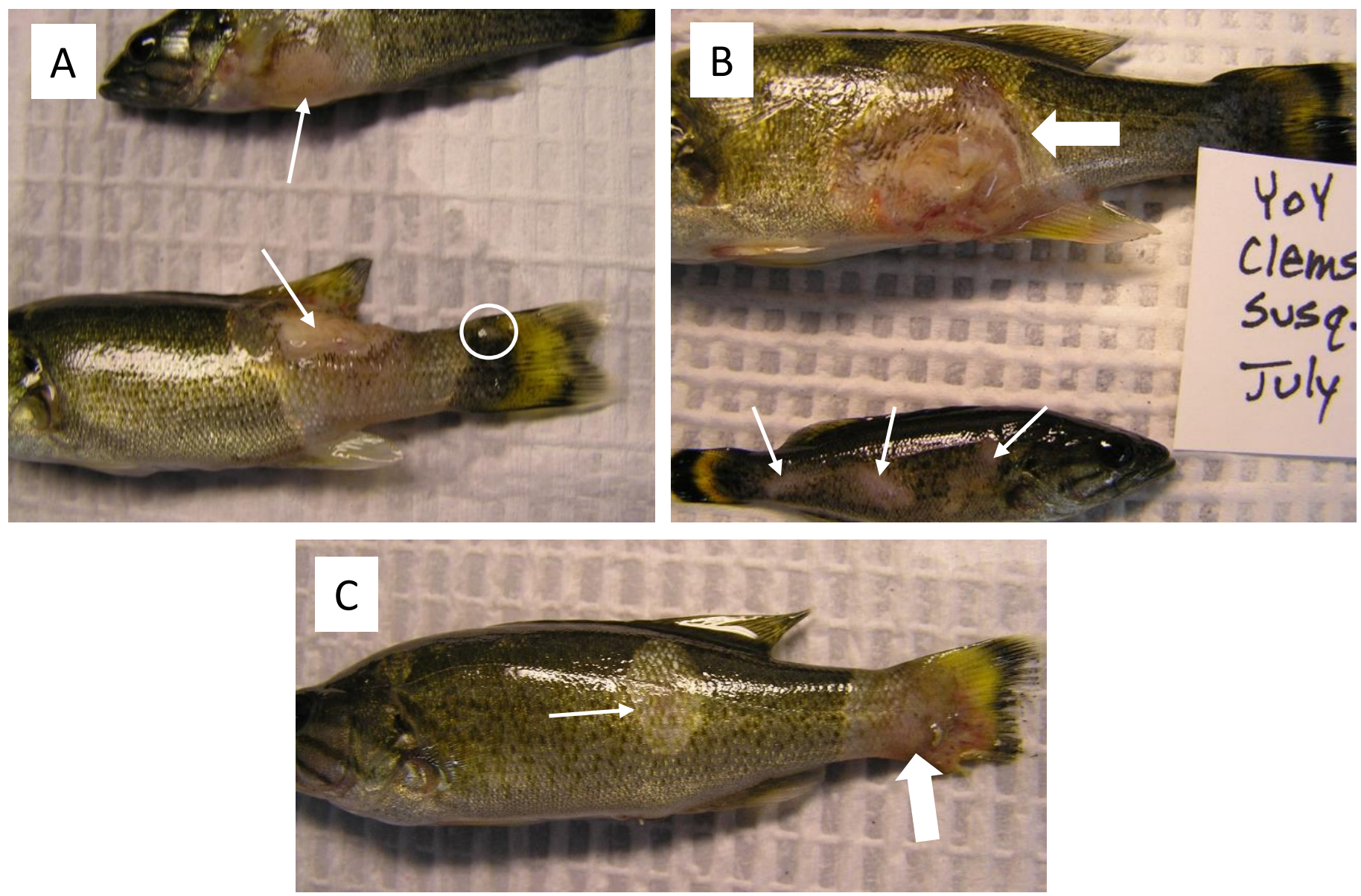
Figure 4. Fluorescence in situ hybridization (FISH) of samples from young-of-the-year smallmouth bass tissues. A) Myxobolus inornatus plasmodium infecting the connective tissue of the muscle, B) Flavobacterium spp. (filamentous bacteria) in the skin, and C) Aeromonas spp. (rod-shaped bacteria), in the gut.
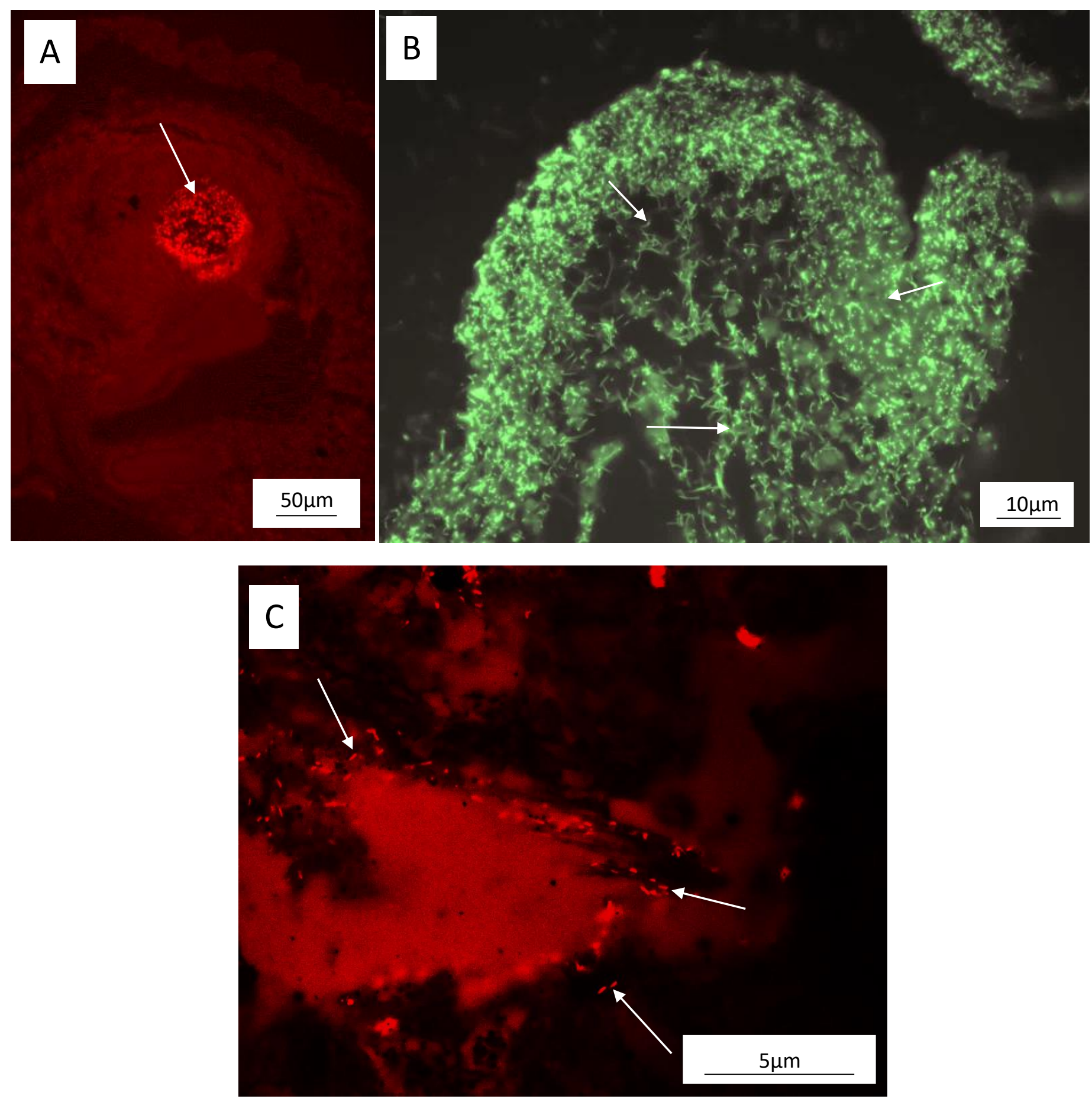
Figure 5. Fluorescence in situ hybridization (FISH) of a co-infection of loose spores of $M$. inornatus (circles) and Flavobacterium spp. (filamentous bacteria, arrows) infecting the connective tissue and soft cartilage around the bone in the caudal peduncle region of a young-ofthe-year smallmouth bass.

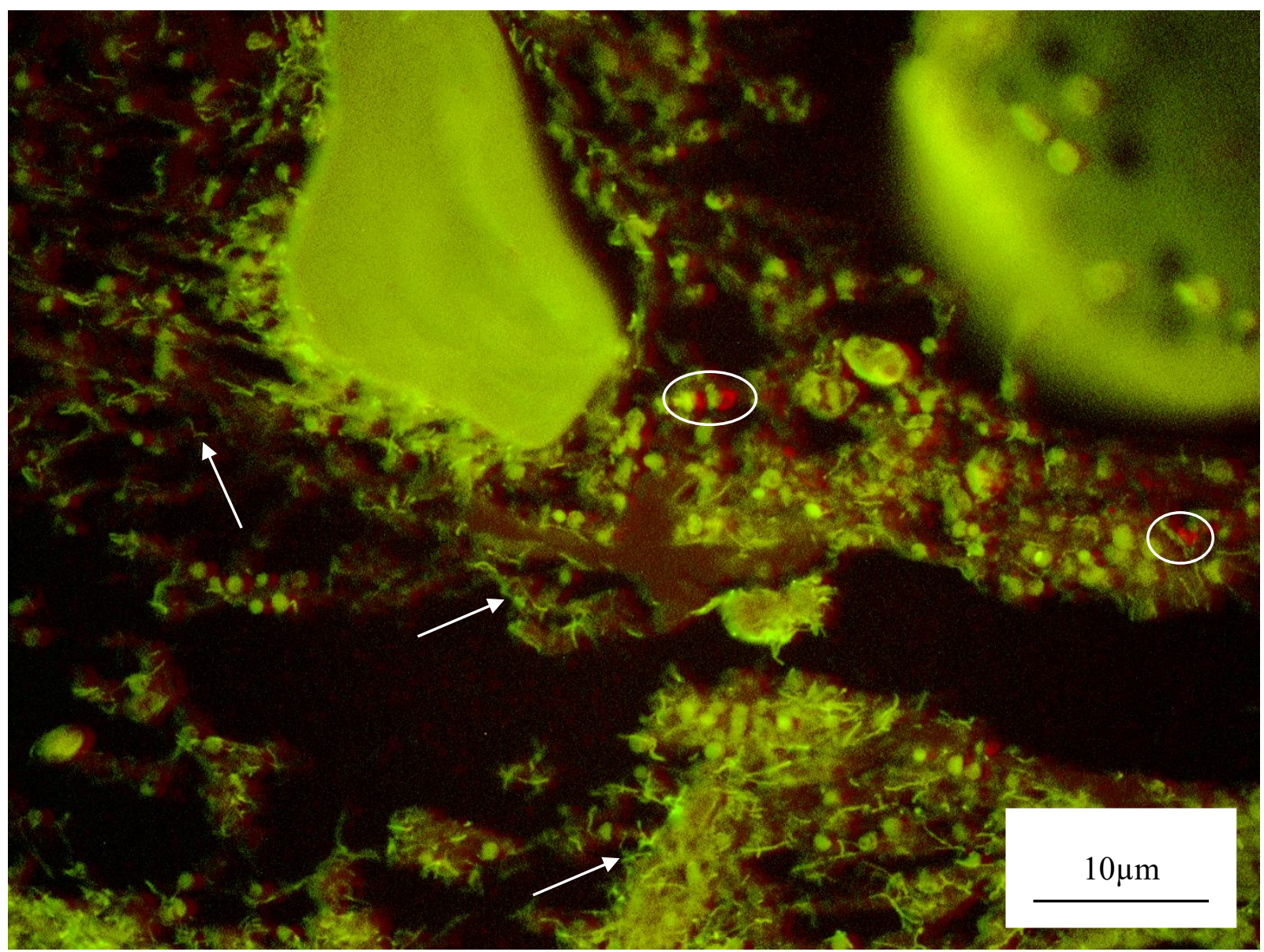




\section{Tables}

Table 1. Probe sequences used in a dual color FISH assay to identify coinfections of Myxobolus inornatus, Flavobacterium spp., and/or Aeromonas spp.

\begin{tabular}{|ccc|}
\hline Probe & Sequence & Original Publication \\
\hline Myxobolus inornatus & 5'-/5Alex546N/TCG ACG CCC TCC CTG ACT CG-3' & Walsh et al. 2018 \\
Flavobacterium spp. & 5'-/5Alex488N/ACC CCT ACC CAT CGT C-3' & Strepparava et al. 2012 \\
Aeromonas spp. & 5'-/5Alex546N/CTA CTT TCC CGC TGC CGC-3' & Kämpfer et al. 1996 \\
\hline
\end{tabular}


Table 2. Number of young-of-the-year smallmouth bass (YOY SMB) collected for histology from four subbasins in the Susquehanna River drainage and two out-of-basin sites (asterisks) in Pennsylvania. The number and percent (\%) of YOY SMB infected with the myxozoan Myxobolus inornatus were determined with routine histopathology.

\begin{tabular}{|c|c|c|c|}
\hline Subbasin & $\begin{array}{c}\text { \# of YOY SMB } \\
\text { Collected }\end{array}$ & $\begin{array}{c}\text { \# of M. inornatus } \\
\text { Infections }\end{array}$ & $\begin{array}{c}\text { \% of M. inornatus } \\
\text { Infections }\end{array}$ \\
\hline West Branch Susquehanna & 157 & 73 & 46 \\
Lower Susquehanna & 134 & 43 & 32 \\
Middle Susquehanna & 25 & 9 & 36 \\
Juniata & 41 & 15 & 37 \\
Allegheny* & 31 & 3 & 10 \\
Delaware* & 21 & 2 & 10 \\
\hline
\end{tabular}




\title{
Chapter Four: Associations of Liver Helminths and Coinfections with Landuse in Young- of-the-Year Smallmouth Bass in the Chesapeake Bay Drainage, USA
}

\begin{abstract}
In the field of fish health, it is increasingly common to include land use variables to better understand disease factors and their spatial existence. In this study, agricultural and developed land use at two spatial scales (local NHD catchment and accumulated catchment) in the Susquehanna and Potomac River basins and two out-of-basin sites in Pennsylvania were used as predicting variables of young-of-the-year smallmouth bass (YOY SMB) Micropterus dolomieu liver helminth and coinfection prevalence. The results showed that coinfection prevalence was positively predicted by agriculture and negatively predicted by development at the local NHD catchment scale. The best predicting variable for liver helminths was development at the local NHD catchment scale, which was negative, and it was weakly predicted to be positive with agriculture at both catchment scales. It is suggested that agricultural land use can increase the intermediate hosts of YOY SMB parasites, influence water quality (such as temperature and nutrification) and contribute to agriculture-associated contaminant runoff. Additionally, out-ofbasin sites in Pennsylvania had lower rates of coinfections than sites in the Susquehanna and Potomac River basins. This type of data is useful for management decisions and can help guide future SMB conservation efforts to focus on land use at the local catchment scale rather than at a large scale.
\end{abstract}

\section{Introduction}


In the Susquehanna River basin, observations from on-going health assessments of young-of-the-year smallmouth bass (YOY SMB) Micropterus dolomieu have identified numerous disease sources, including coinfections of pathogenic bacteria, largemouth bass virus (LMBV; Starliper et al. 2013), parasites, and systemic infections (Walsh et al. 2018). The types of parasites observed in coinfections include helminth parasites in multiple tissues (Walsh et al. 2018) and the myxozoan Myxobolus inornatus (Walsh et al. 2012). Helminth parasites, such as larval cestodes (plerocercoids) and digenean trematodes, can cause significant damage to tissues including inflammation, necrosis, and tissue replacement (Joy and Madan 1989) and can cause juvenile fish mortalities (Hoffman 1999). In YOY SMB, helminth and myxozoan parasite infections may increase the risk of secondary bacterial infections by causing breaks in the mucus and skin during invasion. Also, the types of parasites infecting YOY SMB have been shown to be associated with anthropogenic land use in SMB and other fish species (Schall et al. 2018; Sures et al. 2017).

Currently, it remains unknown how liver helminths and coinfections of parasites are associated with land use in the Susquehanna River basin. Liver helminths, including cestodes and digenean trematodes, are common parasites of smallmouth bass (Gillilland et al. 2004; Miller 1954). Trematodes have complex lifecycles involving a bird, snail, and fish hosts (Hoffman 1999). Cestodes have less complex lifecycles involving a final fish host and a primary host such as a copepod, amphipod, or isopod (Hoffman 1999). Both types of helminths are capable of migration through the liver and in doing so induce inflammation and destroy host tissue (Fischer and Freeman 1969; Joy and Madan 1989; Miller 1954). In some areas, helminth parasite abundance has been shown to increase in the summer (Fiorillo and Lutterschmidt 2015) at a time when water temperatures are favorable for increased pathogenesis of bacteria such as 
motile Aeromonads (Camus 1998) and Flavobacterium spp. (Loch and Faisal 2015). In juvenile fish, parasitic coinfections have been shown to increase mortality rates (Busch et al. 2003; Ferguson et al. 2011) and cause an impaired immune response (Ezenwa and Jolles 2011). For YOY SMB, which develop during the summer, these effects may play a role in disease and mortality.

Many studies have examined the influence of land use on parasite infections in aquatic organisms (Chapman et al. 2015; Fiorillo and Lutterschmidt 2015; Hartson et al. 2011; King et al. 2010). In fish, land use effects, such as nutrification, chemical contamination, thermal changes, and habitat alterations can impact parasitism (MacKenzie et al. 1995). In particular, eutrophication and increasing water temperatures can lead to an increase in parasite abundance (Lafferty 2008; Lõhmus and Björklund 2015). Thus, parasites respond to anthropogenic effects in various ways and those with complex lifecycles, such as helminths, can be affected during transmission between hosts (Pietrock and Marcogliese 2003) and by host availability (Hartson et al. 2011). In frogs, a decline in parasite diversity and species richness was associated with agriculture and reduced forest cover (King et al. 2010). In contrast, agricultural activity has been associated with an increase in parasite abundance in fish (Chapman et al. 2015).

In studies analyzing land use and fish health metrics, spatial scale has been determined to be influential. Previous work has found associations between land use at the local scale and physiological processes in fish (Jeffrey et al. 2015), parasite abundance (Schall et al. 2018) and parasite diversity (Blanar et al. 2016). Differences in landscape-based factors are known to exist when catchment size is taken into consideration. Land use effects at a large scale are predominantly influenced by climate, slope, sediment type and land cover, while small scale, site effects are guided by flow and depth, riparian cover, and sediment load (DeAngelis and Curnutt 
2002). In the Susquehanna River basin, agricultural land use within the local catchment was determined to be associated with a greater prevalence of M. inornatus. It was proposed that agricultural settings may provide more appropriate habitat for the intermediate host and pesticides may have immunomodulatory effects on YOY SMB decreasing their resistance to the myxozoan (Schall et al. 2018).

The objective of the current study is to develop a hierarchical logistic regression model to determine the spatial variability of liver helminths and coinfections in YOY SMB. Histopathology will be used to determine the presence/absence of liver helminths and coinfections. To determine the effects of land use and scale, prevalence data will be incorporated into a model with agricultural and developed land use at two spatial scales: local (catchment associated with each site) and accumulated (all catchments upstream from each site). Modeling these associations will provide insight on the spatial extent of liver helminths and coinfections and clarify the role of these variables in YOY SMB disease. Understanding how parasites and disease are associated with land use will enable management decisions to be made on how disease in YOY SMB can be mitigated in the future.

\section{Methods}

Fish Sampling

In 2013-2016 up to 20 YOY SMB (2-3 months old) were sampled with backpack electroshockers from each sampling site within the Susquehanna and Potomac River basins and the out-of-basin sites in Pennsylvania. Sub-basins within the Susquehanna River basin included the West Branch, North Branch, Lower, and Juniata. Out-of-basin sites were located in the Allegheny and Delaware River basins and were included due to previous findings of low disease 
prevalence in YOY SMB. Unlike previous sampling for YOY SMB that targeted only diseased fish (Starliper et al. 2013; Walsh et al. 2018), normal and diseased fish were collected for this study. Young-of-the-year SMB from the Potomac River basin in Maryland and West Virginia were also sampled. Although YOY SMB have not experienced mortality in the Potomac River basin, preliminary findings included similar parasites as YOY SMB in the Susquehanna River basin and were therefore sampled as an out-of-state comparison (personal observation). In the Potomac River basin adult SMB have also experienced a high prevalence of disease and mortality (Blazer et al. 2010).

All fish were humanely euthanized with tricane methanesulfonate (MS-222; Argent Labs, Redmond, Washington), a slit was cut along the ventral side, and they were placed in Z-Fix ${ }^{\circledR}$ (Antech, Battle Creek, Michigan) for histological examination.

\section{Histopathology}

Fish were allowed to fix for at least $24 \mathrm{hrs,} \mathrm{decalcified} \mathrm{in} \mathrm{EDTA} \mathrm{(Sigma-Aldrich,} \mathrm{St.}$ Louis, Missouri) and routinely processed for histology (Luna 1992) at the U.S. Geological Survey National Fish Health Research Laboratory in Kearneysville, West Virginia. Paraffin embedded sections were cut at $5 \mu \mathrm{m}$ and stained with hematoxylin and eosin (H\&E).

The prevalence of helminths in the liver (total number of fish with liver helminths / total number of fish $\mathrm{x}$ 100) was determined with histopathology and included both trematodes and larval cestodes (Figure 1). The prevalence of coinfections (total number of fish with coinfections / total number of fish $\mathrm{x}$ 100) was determined as described in Walsh et al. (2018) as a combination of three or more of the following: M. inornatus infections, helminth parasites in the muscle, liver, and mesentery (spleen, kidneys, and gut), skin lesions, and/or systemic infections. 


\section{Predictor Variables}

Predictor variables and modeling efforts were focused on explaining spatial variability in prevalence of liver helminths and coinfections related to site locations rather than temporal variability given the limited temporal scope of the study $(n=4$ years). Site related characteristics were summarized similar to methods in Schall et al. (2018), which used developed and agricultural land use at two spatial scales to investigate spatial variability in a myxozoan parasite in YOY smallmouth bass. Land use data were obtained from the National Land Cover Dataset (NLCD 2011; Homer et al. 2015) and summarized across categories of development (low, medium, and high) and agriculture (pasture and crops). The two spatial scales included an immediate catchment or local scale, as defined by the National Hydrography Dataset V2+ (NHD; National Hydrology Dataset Plus Version 2, U.S. Geological Survey and U.S. Environmental Protection Agency, accessed online at: http://www.horizon-

systems.com/NHDPlus/NHDPlusV2_02.php) the accumulated catchment scale, which included land use in all upstream NHD catchments from the site location. Several sites in the Potomac River Basin including the Conococheague Creek, Potomac River, Potomac River Middle, and Potomac River Cumberland to Spring Gap are represented by average land use from multiple sites. Land use was averaged because samples from these sites were composited during collections due to low sample sizes at individual sites.

\section{Statistical Model}

A hierarchical logistic regression model was fitted using Bayesian inference to each YOY SMB disease data set (coinfection and liver helminth prevalence) independently to evaluate site- 
specific land use predictors and variability in prevalence of liver helminths and coinfections. A site random effect was included to accommodate lack of independence in the dataset due to multiple observations from sites. For each data set an observation and site specific-level model were included as follows:

Observation-level:

$$
\operatorname{Pr}\left(y_{i}=1\right)=\operatorname{logit}^{-1}\left(\delta_{j[i]}\right), \text { for } i \text { in } 1 \ldots, 1426 \text { observations }
$$

(Equation 1)

Site-level:

$$
\begin{gathered}
\delta_{j} \sim N\left(\beta_{0}+\beta_{1} * \operatorname{AgNHD}_{j}+\beta_{2} * \operatorname{DevNHD}_{j}+\beta_{3} * \text { AgAccum }_{j}+\beta_{4} * \text { DevAccum }_{j}, \sigma_{\delta}^{2}\right), \text { for } j \\
\text { in } 1 \ldots, 46 \text { sites }
\end{gathered}
$$

(Equation 2)

Where $y_{i}=1$ if a fish was positive for the disease characteristic of interest (e.g., coinfection prevalence or liver helminth prevalence) and $\delta_{j[i]}$ is the site random effect. The site random effect was modeled with the overall intercept $\beta_{0}$, coefficients for the relationships between agriculture and development and average disease prevalence of interest $\left(\beta_{1}, \ldots, \beta_{4}\right)$ at two different spatial scales (NHD catchment-NHD and accumulated upstream catchment Accum), and conditional variance, $\sigma_{\delta}^{2}$. Land use variables were logit-transformed and standardized prior to analysis.

Models were fitted in Program R (R Core Team 2017) using the Jags UI package (Kellner 2016). A total of 90,000 iterations were used with three parallel Markov chains, and 40,000 iterations for burn-in. Thinning was conducted with every third value retained for analysis. Priors included diffuse normal and uniform priors for $\beta_{0}$ and $\sigma_{\delta}^{2}$, respectively and a Bayesian Lasso (lease absolute shrinkage and selection operator; Tibshirani 1996, Hooten and Hobbs 2015) for land use regression coefficients $\left(\beta_{1}, \ldots, \beta_{4}\right)$ to account for correlation between 
land use variables. The Bayesian Lasso Prior included a double exponential distribution:

$\beta_{1, . .4} \sim \operatorname{dexp}(0, \gamma)$ where $\gamma \sim \exp (10)$

Final model fitting and convergence were evaluated using trace plots and $\hat{R}$ convergence statistics. Posterior distributions were summarized with all results reported as the posterior mean and $95 \%$ credible interval unless otherwise noted. In addition, for land use slope coefficients $\left(\beta_{1}, \ldots, \beta_{4}\right)$ the probability that the posterior distribution was in the direction of the posterior mean was also summarized. For example, if there was a slope in a positive direction, the probability that the relationship was positive from the posterior distribution was also summarized to provide more insight on uncertainty in the relationship.

\section{Results}

Histopathological Analyses

During the four sampling years, the prevalence of coinfections was greatest in the Potomac River basin, similar in the Lower and West Branch Susquehanna and Juniata subbasins, and lowest in the out-of-basin Pennsylvania and North Branch Susquehanna sub-basin sites (Figure 2A). A breakdown of the variables included in coinfection prevalence is provided by year (Table 1) and by sub-basin across all years (Figure 3). There were years where no coinfections were observed in the Delaware basin and North Branch Susquehanna sub-basin (Figure 2A). The greatest prevalence of skin lesions and systemic infections were observed in the Juniata, Lower, and West Branch Susquehanna sub-basins and in the Potomac River basin (Figure 3). For parasites, the lowest prevalence of M. inornatus was observed in the out-of-basin Pennsylvania sites; however, the highest prevalence of muscle and mesenteric helminths was observed in the Allegheny sites. Liver helminth prevalence was lowest in the out-of-basin 
Pennsylvania and North Branch Susquehanna sub-basin sites and highest in the Juniata sub-basin (Figure 2B). Helminths in the mesentery were slightly higher in the out-of-basin Pennsylvania sites and no muscle helminths were observed in the Delaware River sites. In most cases, the occurrence of coinfections seemed to be most influenced by parasite infections and not skin lesions or systemic infections.

\section{Statistical Modeling}

\section{$\underline{\text { Land Use Overview }}$}

The land use data from sites used in the model (agNHD, devNHD, agAccum, devAccum) covered a range of land use gradients (proportion in the local NHD catchment or accumulated catchment). For devNHD, proportion ranged from $0-0.88$, with a mean of 0.24 and devAccum ranged from $0.00-0.20$ with a mean of 0.08 . The low mean land use gradient for the devAccum consisted primarily of low developed land use and lacked a gradient from low to high. agNHD ranged from 0.00-0.72 with a mean of 0.21 and agAccum ranged from 0.05-0.64 with a mean of 0.26 .

The proportion of agriculture and development for each sub-basin and basin are provided in Table 2. For devAccum, only the Delaware River basin and Lower Susquehanna sub-basin sites had a mean $>0.1$. Mean $\operatorname{devNHD}$ was $>0.1$ at all sites except for the North Branch Susquehanna sub-basin. For agAccum, all sites had a mean $>0.1$, with the mean at two sites $>$ 0.3 (Lower and North Branch Susquehanna sub-basins). Mean $a g N H D$ was $<0.1$ at the out-ofbasin Pennsylvania sites with two basins > 0.3 (Juniata sub-basin and Potomac River basin). 


\section{$\underline{\text { Coinfection Prevalence }}$}

Coinfection prevalence varied across sites and basin of origin $\left(\sigma_{\delta}\right.$; Table 3 and Figure 4$)$. The overall estimate for coinfections across sites with average land use was $1.31(0.93,1.82$; posterior mean and $95 \%$ credible interval). In general, sites within the Susquehanna River basin had higher estimates of coinfection prevalence than sites outside of the Susquehanna River basin, but inside the state of Pennsylvania (Figure 5). Within the Susquehanna River basin, four out of 27 sites had mean coinfection prevalence estimates higher than 0.40 (Bald Eagle Unionville1, Chillisquaque Creek, Sherman Creek, and Susquehanna River Mahantango). The highest coinfection prevalence estimate in the Susquehanna River was at Sherman creek with a posterior mean of $0.78(0.61,0.91 ; 95 \%$ credible interval $)$ at Sherman Creek. Several sites in the Susquehanna River Basin also had relatively low estimates of coinfection prevalence (prevalence $<0.10$ ) including Bald Eagle Creek Castanea, Kettle Creek, Susquehanna River Danville, Susquehanna River Falls, and Wyalusing Creek. The low coinfection prevalence estimates in the Susquehanna River basin were similar to most of the out-of-basin sites in Pennsylvania which had three of six sites with estimates $<0.10$ and all estimates less than the average prevalence estimate across all sites and average land use. The Potomac River basin sites exhibited similar coinfection prevalence estimates to sites in the Susquehanna River Basin with considerable site specific variability. Several sites (four out of thirteen) had elevated coinfection prevalence estimates (>0.40) including Conococheague Creek, Potomac River Brunswick, Potomac River McCoys Ferry, and South Branch Potomac River.

Coinfection prevalence relationships with land use were not statistically significant at the different scales or land use investigated; however, two of the four coefficients $\left(\beta_{1}\right.$ and $\left.\beta_{2}\right)$ had a high probability $(>0.80)$ of being in the direction of the posterior mean (Table 3$)$. In general, 
relationships with land use predictors and coinfection prevalence were stronger at the local NHD scale than the accumulated upstream catchment scale. The relationship between agriculture and coinfection prevalence was positive at both spatial scales (NHD $=0.86$ (Figure 6), accumulated catchment $=0.77$; Table 3 ). The relationship between coinfection prevalence and developed land use was negative at the local NHD scale (Table 3 and Figure 7) but switched directions at the accumulated catchment scale; however, the probability was weak (Table 3).

\section{$\underline{\text { Liver Helminth Prevalence }}$}

Liver helminth prevalence varied across sites both within and outside of the Susquehanna River basin $\left(\sigma_{\delta}\right.$; Table 3, Figure 8). Overall estimates of liver helminth prevalence across all sites and with average land use was $1.58(1.15,2.13$; posterior mean and $95 \%$ credible interval). Within the Susquehanna River basin, nine out of 27 sites had a mean liver helminth prevalence greater than 0.50 including Bald Eagle Unionville1, Bald Eagle Unionville2, Conodoguinet Creek, Juniata River Newport, Penns Creek, Sherman Creek, Swatara Creek, Tuscarora Creek, and WB Susquehanna River McElhattan (Figure 9). The highest liver helminth prevalence estimates across all sites in the Susquehanna River basin and within the entire dataset was Sherman Creek with a posterior mean of $0.84(0.68,0.95 ; 95 \%$ credible interval). Several sites in the Susquehanna River Basin had low liver helminth prevalence $(<0.10)$ including Kettle Creek, Susquehanna River Falls, Susquehanna River Isle of Ques, WB Mahantango Creek, and WB Susquehanna River Jersey Shore. The out-of-basin sites within the state of Pennsylvania had lower prevalence in general than did the Susquehanna or Potomac River basins although there was also some variability in the out-of-basin sites. The highest liver helminth prevalence in the out-of-basin sites within the state of Pennsylvania was the Delaware River Matamoras site 
with a posterior mean of $0.34(0.20,0.50 ; 95 \%$ credible interval). In the Potomac River basin, liver helminth prevalence estimates varied similar to that of the Susquehanna River basin. Seven out of thirteen sites had mean estimates of liver helminth prevalence greater than 0.50 (Conococheague Creek, Potomac River, Potomac River Brunswick, Potomac River McCoys Ferry, Potomac River Spring Gap, Potomac River Whites Ferry, and South Branch of the Potomac River). Only one site in the Potomac River basin had liver helminth prevalence less than 0.1 (Potomac River Cumberland to Spring Gap).

Land use relationships with liver helminth prevalence were not statistically significant with any of the land use predictors investigated. Two out of four $\left(\beta_{2}\right.$ and $\left.\beta_{4}\right)$ coefficients did have a relatively high probability ( $>0.80$ ) of being in the direction of the posterior mean. For liver helminth prevalence, relationships with agriculture were weak (probability of being in direction of the posterior mean $<0.60$ ) and close to zero at both the NHD and accumulated catchment scale (Table 3). Relationships between liver helminth prevalence and developed land use had $>0.80$ probability of being in the direction of the posterior mean at both spatial scales (Table 3). The relationships were not consistent however, with there being a negative relationship between helminth prevalence and development at the NHD catchment scale (probability $=0.87$; Figure 10 and Table 3 ) and a positive relationship between liver helminth prevalence and development at the accumulated catchment scale (probability $=0.88$; Figure 11 and Table 3).

\section{Discussion}

In this study, YOY SMB were examined for the prevalence of coinfections and liver helminths and used in a hierarchal logistic regression model to determine predictability with land 
use variables. Different spatial scales of agriculture and development were included to determine if land use within the site-specific NHD local catchment or accumulated catchment (all catchments upstream of each site) were useful predictors. Many stream ecology studies focus on land use at the local scale; however, due to the high interconnectivity of riverine systems, large scale analyses should also be considered (Allan 2004). In a previous study on YOY SMB, agNHD positively predicted $M$. inornatus infections and infection rates were suggested to be influenced by increased nutrification and the myxozoan intermediate host (Schall et al. 2018). The results of the current study showed agriculture and development at multiple spatial scales can be used to model coinfections and liver helminth prevalence in YOY SMB. Additionally, understanding how stress is associated with landscape alterations (Jeffrey et al. 2015) may also help tease out the site variability in coinfections and liver helminth prevalence observed in this study.

With histopathology, the prevalence of liver helminths and coinfections was determined for YOY SMB from four sub-basins in the Susquehanna River basin, two out-of-basin sites in Pennsylvania (Allegheny and Delaware River basins), and from the Potomac River basin in Maryland and West Virginia. Overall, YOY SMB from the out-of-basin sites in Pennsylvania had a lower prevalence of coinfections than fish from other sites. Mean agricultural land use was much less in the out-of-basin sites and greater in the Susquehanna and Potomac River basins. Previously, YOY SMB sampled in the out-of-basin sites had a lower prevalence of disease than YOY SMB sampled in the Susquehanna River basin (Chaplin and Crawford 2012). Although YOY SMB from the Allegheny and Delaware River basins had a similar prevalence of liver helminths to fish from the Susquehanna and Potomac River basins, there were almost no cases of skin lesions or systemic infections. The occurrence of skin lesions and systemic infections were 
greatest in the Juniata, Lower, and West Branch Susquehanna sub-basins and the Potomac River basin. Of the four land use predictors, only $a g N H D$ was the most different between the out-ofbasin sites and these three Susquehanna River sub-basins and Potomac River basin (Table 2). Similarly, adult SMB sampled in the Potomac River basin had higher rates of skin lesions at sites with a greater percentage of agricultural land use compared to a forested reference site (Blazer et al. 2010). In the study by Walsh et al. (2018), five chemicals (p,p'-DDE, p,p'-DDT, pendimethalin, bifenthrin, and pyraclostrobin) associated with agricultural land use were detected in YOY SMB from the Susquehanna River basin. Agricultural chemicals have been shown to have immunomodulatory effects in fish and other aquatic organisms (Matthiessen et al. 2018) and may prevent YOY SMB from coping with other stressors, such as parasites and pathogens. Further work deriving associations between agricultural land use, contaminants, and YOY SMB in the Susquehanna and Potomac River basins should be investigated to better understand this relationship.

When coinfection variables were examined independently, changes in prevalence were observed for individual sub-basins when compared to previous data of YOY SMB sampled in 2007-2012 (Walsh et al. 2018). In all Susquehanna River sub-basins, the prevalence of systemic infections and skin lesions declined. Although it should be noted that this study sampled both diseased and normal fish while only visibly diseased fish were previously sampled. Nonetheless, the cause of systemic infections remains unknown. Lesion pathology is similar to that of YOY SMB experimentally infected with LMBV (Boonthai et al. 2018) but is also similar to internal lesions induced by pathogenic bacteria (Kumar et al. 2016; Thune et al. 1993). Both LMBV and opportunistic bacterial pathogens are influenced by temperature (Hamad et al. 2018; Grant et al. 2003; Grizzle and Brunner 2003) and can become more virulent when water temperature 
increases. Additionally, nutrient availability can impact bacteria pathogenesis (Hamad et al. 2018). However, according to the Susquehanna River Basin Commission (2017) nutrient and sedimentation loads have decreased over time. Hence, a change in nutrient loads in the Susquehanna River basin could be associated with the decrease in skin lesions and systemic infections in YOY SMB. Additional YOY SMB sampling in upcoming years including nutrient and temperature data at each site could aid in determining if differences exist which may contribute to a decrease in lesions.

For M. inornatus, only YOY SMB in the Lower Susquehanna sub-basin showed an increased prevalence while prevalence in other sub-basins remained relatively the same compared to previous years (Walsh et al. 2018). The prevalence of muscle helminths decreased in all four Susquehanna River sub-basins while the prevalence of liver helminths increased in all Susquehanna sub-basins except for the North Branch Susquehanna sub-basin where it decreased. Although previous data does not exist for YOY SMB from the Potomac River basin, the prevalence of coinfections and liver helminths were similar to fish from the Juniata, Lower, and West Branch sub-basins. The increase in liver helminths in all Susquehanna sub-basins could be associated with changes in intermediate host assemblages which are responsive to environmental changes. In some cases, agricultural land use can have more of an impact then urban land use on benthic invertebrate density due to increased nutrient runoff (Herringshaw et al. 2011) and differences in contaminant runoff (Fitzpatrick et al. 2007). Agricultural land use has also been associated with increased pathological alterations in the liver of fish (Neves et al. 2018) and may increase YOY SMB susceptibility to liver helminths. Temperature can also influence parasite abundance and many types of helminth parasites have been shown to respond positively to increasing water temperatures (Khan and Thulin 1991). An increase in water temperature may 
accelerate parasite growth and reproduction but also can affect host behavior (Marcogliese 2001). A rise in water temperature may cause fish to reside in areas outside of their usual habitat due to shifts in prey availability or oxygen requirements (Ficke et al. 2007). Additionally, contaminants have been shown to be more toxic to fish at higher temperatures (Dietrich et al. 2014; Laetz et al. 2014) and could also be more toxic to parasites as well. Thus the increase in liver helminth prevalence in YOY SMB may be best explained by site specific changes in water quality due to shifts in land use. Future work to identify liver helminth species and their lifecycles would help elucidate how they are affected by land use and why they have increased at most sites.

Spatial scale effects of land use have been shown to affect factors which can impact stream systems differently (Buck et al. 2004). For example, in a study by Shi et al. (2017) it was found that scale effects occurred between small and large catchment sizes. They found that urban land use was a better predictor of degraded water quality at small scales and agricultural land use was a better predictor at a large catchment scale. Similarly, in the current study scale of agriculture and development was determined to be important for predicting liver helminth and coinfection prevalence. In YOY SMB, it was found that coinfection prevalence was best explained by development and agricultural land use at the local NHD catchment scale than at the accumulated catchment scale. At the local NHD catchment scale, coinfection prevalence was strongly negative with the proportion of developed land use and positive with the proportion of agricultural land use. Agriculture is known to cause stream degradation by clearance of riparian habitats (Allan 2004) which has a strong influence on stream temperature (Albertson et al. 2018). Young-of-the-year smallmouth bass have been shown to prefer habitat patches with warmer water (Brewer 2013) and may be utilizing agriculture-impacted habitats for this reason. In a 
report by Smith et al. (2015) it was suspected that habitat selection was a contributing factor of disease in YOY SMB. Previously, YOY SMB exhibited higher rates of coinfections at sites where the greatest number of agricultural chemicals and hormones were detected in the water (Walsh et al. 2018). In this study, coinfection prevalence greater than 0.40 was observed at the same sites in the Susquehanna River basin where these chemicals were previously detected. At four sites in the Potomac River basin, coinfection prevalence was also similar to fish from the Susquehanna River basin sites. Contaminant data sampled at the same time fish are sampled would elucidate whether chemical levels have dropped or remain steady and if they are associated with coinfections. Additionally, future YOY SMB and water chemistry sampling at the Potomac River basin sites would provide temporal data on coinfections and contaminants in this region.

Similar to coinfections, liver helminth prevalence was also predicted to be negatively associated with the proportion of NHD development. However, unlike coinfection predictability, it showed a positive association with the proportion of development at the accumulated catchment scale. Although agriculture was a strong predictor of coinfections at the NHD and accumulated catchment scales, it was a weak, positive predictor of liver helminth prevalence. As previously mentioned, the mean and range of developed land use was limited at the accumulated catchment scale and primarily consisted of low development. Therefore, at the accumulated scale, low development land use could have similar effects on liver helminth prevalence as agricultural land use. This may be likely since similar to coinfection prevalence, liver helminth prevalence was predicted to decrease with increasing proportion of devNHD. Multiple sites in the Susquehanna and Potomac River basins had a prevalence of liver helminths greater than 0.50 , including many of the same sites that had a high coinfection prevalence. In frogs, an increase in 
contaminants associated with agricultural land use was shown to increase trematode infections by inducing host immunosuppression and increasing algae and snail abundance (Rohr et al. 2008). The intermediate, copepod hosts of cestodes (common in the livers of YOY SMB) have been shown to be influenced by riparian cover, nutrients, and water temperature (MantykaPringle 2014). Future work that teases out the effects of low, medium, and high development independently could be useful to better understand how land use gradients may affect liver helminth prevalence in YOY SMB.

This temporal and spatial study of YOY SMB in the Susquehanna and Potomac River basin provides important data on disease and land use relationships which can be used to improve SMB conservation efforts. The results of this study indicate that agricultural land use at a local catchment scale should be considered for remediation and management efforts. Future modeling efforts could also include nutrient loads, contaminant, and water quality data with land use at the local scale to identify areas for best management initiatives for disease control in SMB. Additionally, this work is important for YOY SMB conservation efforts in the Potomac River basin. Although mortalities of YOY SMB have not yet occurred in the Potomac River basin, the similarity of disease symptoms to fish in the Susquehanna River basin could be used as an early warning marker of a fishery in distress. For example, the parasites and disease described in this study can be considered cumulative stressors and a shift in water quality in the Potomac River basin could cause fish to become immunosuppressed to the point of mortality. Although the results of this study show a decline in skin lesions and systemic infections, an increase in liver helminths was observed at most sites. The damage associated with liver helminths can cause mortalities in juvenile fish (Hoffman 1999); therefore these parasites should be considered a serious stressor and future work should be done to understand their lifecycles 
and how they are associated with land use. The information provided in this study will enable managers and state agencies to decide how to conduct future studies on YOY SMB and how to incorporate land use effects into their decision-making.

\section{References}

Albertson, L.K., Ouellet, V., \& Daniels, M.D. (2018). Impacts of stream riparian buffer land use on water temperature and food availability for fish. Journal of Freshwater Ecology, 33, 195210.

Allan, J.D. (2004). Landscapes and riverscapes: the influence of land use on stream ecosystems. Annual Review of Ecology, Evolution, and Systematics, 35, 257-284.

Blanar, C.A., Hewitt, M., McMaster, M., Kirk, J., Wang, Z., Norwood, W., \& Marcogliese, D.J. (2016). Parasite community similarity in Athabasca River trout-perch (Percopsis omiscomaycus) varies with local-scale land use and sediment hydrocarbons, but no distance or linear gradients. Parasitology Research, 115, 3853-3866.

Blazer, V.S., Iwanowicz, L.R., Starliper, C.E., \& Iwanowicz, D.D. (2010). Mortality of centrarchid fishes in the Potomac drainage: survey results and overview of potential contributing factors. Journal of Aquatic Animal Health, 22, 190-218.

Boonthai, T., Loch, T.P., Yamashita, C.J., Smith, G.D., Winters, A.D., Kiupel, M., Brenden, T.O., \& Faisal, M. (2018). Laboratory investigation into the role of largemouth bass virus (Ranavirus, Iridoviridae) in smallmouth bass mortality events in Pennsylvania rivers. BMC Veterinary Research, 14, 1-15.

Buck, O., Niyogi, D.K., \& Townsend, C.R. (2004). Scale-dependence of land use effects on water quality of streams in agricultural catchments. Environmental Pollution, 130, 287299.

Busch, S., Dalsgaard, I., \& Buchmann, K. (2003). Concomitant exposure of rainbow trout fry to Gyrodactylus derjavini and Flavobacterium phychrophilum: effects on infection and mortality of host. Veterinary Parasitology, 117, 117-112.

Brewer, S.K. (2013). Groundwater influences on the distribution and abundance of riverine smallmouth bass, Micropterus dolomieu, in pasture landscapes of the Midwestern USA. River Research and Applications, 29, 269-278.

Camus, A.C., Durborow, R.M., Hemstreet, W.G., Thune, R.L., \& Hawke, J.P. (1998). Aeromonas bacterial infections - motile aeromonad septicemia. Southern Regional Aquaculture Center, 478, 1-4. 
Chaplin, J.J. \& Crawford, J.K. (2012). Streamflow and water-quality monitoring in response to young-of-year smallmouth bass (micropterus dolomieu) mortality in the Susquehanna River and major tributaries, with comparisons to the Delaware and Allegheny Rivers, Pennsylvania, 2008-10: U.S. Geological Survey Open-File Report 2012-1019, 39 p.

Chapman, J.M., Marcogliese, D.J., Suski, C.D., \& Cooke, S.J. (2015). Variation in parasite communities and health indices of juvenile Lepomis gibbosus across a gradient of watershed land-use and habitat quality. Ecological Indicators, 57, 564-572.

Coles, J.F., McMahon, G., Bell, A.H., Brown, L.R., Fitzpatrick, F.A., Scudder Eikenberry, B.C., Woodside, M.D., Cuffney, T.F., Bryant, W.L., Cappiella, K., Fraley-McNeal, L., \& Stack, W.P. (2012). Effects of urban development on stream ecosystems in nine metropolitan study areas across the United States: U.S. Geological Survey Circular 1373, 138 p. Available online at http://pubs.usgs.gov/circ/1373/.

DeAngelis, D.L. \& Curnutt, J.L. (2002). Integration of population, community, and landscape indicators for assessing effects of stressors. In S.M. Adams (Ed.), Biological indicators of aquatic ecosystem stress (pp. 509-532). Bethesda, Maryland: American Fisheries Society.

Dietrich, J.P., Van Gaest, A.L., Strickland, S.A., \& Arkoosh, M.R. (2014). The impact of temperature stress and pesticide exposure on mortality and disease susceptibility of endangered Pacific salmon. Chemosphere, 108, 353-359.

Ezenwa, V.O. \& Jolles, A.E. (2011). From host immunity to pathogen invasion: the effects of helminth coinfection on the dynamics of microparasites. Integrative and Comparative Biology, 51, 540-551.

Ferguson, J.A., Koketsu, W., Ninomiya, I., Rossignol, P.A., Jacobson, K.C., \& Kent, M.L. (2011). Mortality of coho salmon (Oncorhynchus kisutch) associated with burdens of multiple parasite species. International Journal for Parasitology, 41, 1197-1205.

Ficke, A.D., Myrick, C.A., \& Hansen, L.J. (2007). Potential impacts of global climate change on freshwater fisheries. Reviews in Fish Biology and Fisheries, 17, 581-613.

Fiorillo, R. \& Lutterschmidt, W.I. (2015). Helminth parasites of two species of Lepomis (Osteichthyes: Centrarchidae) from an urban watershed and their potential use in environmental monitoring. Georgia Journal of Science, 73, 123-135.

Fischer, H. \& Freeman, R.S. (1969). Penetration of parenteral plerocercoids of Proteocephalus ambloplitis (Leidy) into the gut of smallmouth bass. Journal of Parasitology, 55, 766774. 
Fitzpatrick, M.L., Long, D.T., \& Pijanowski, B.C. (2007). Exploring the effects of urban and agricultural land use on surface water chemistry, across a regional watershed, using multivariate statistics. Applied Geochemistry, 22, 1825-1840.

Gillilland III, M.G. \& Muzzall, P.M. (2004). Microhabitat analysis of bass tapeworm, Proteocephalus ambloplitis (Eucestoda: Proteocephalidae), in smallmouth bass, Micropterus dolomieu, and largemouth bass, Micropterus salmoides, from Gull Lake, Michigan, U.S.A. Comparative Parasitology, 71, 221-225.

Grant, E.C., Philipp, D.P., Inendino, K.R., \& Goldberg, T.L. (2003). Effects of temperature on the susceptibility of largemouth bass to largemouth bass virus. Journal of Aquatic Animal Health, 15, 215-220.

Grizzle, J.M. \& Brunner, C.J. (2003). Review of largemouth bass virus. Fisheries, 28, 10-14.

Hamad, S.B., Ranzani-Paiva, M.J.T., Tachibana, L., de Carla Dias, D., Ishikawa, C.M., Esteban, M.A. (2018). Fish pathogen bacteria: adhesion, parameters influencing virulence and interaction with host cells. Fish and Shellfish Immunology, 80, 550-562.

Hartson, R.B., Orlofske, S.A., Melin, V.E., Dillon Jr., R.T., \& Johnson, P.T.J. (2011). Land use and wetland spatial position jointly determine amphibian parasite communities.

EcoHealth, 8, 485-500.

Herringshaw, C.J., Stewart, T.W., Thompson, J.R., \& Anderson, P.F. (2011). Land use, stream habitat and benthic invertebrate assemblages in a highly altered Iowa watershed. The American Midland Naturalist, 165, 274-293.

Hoffman, G.L. (1999). Parasites of North American freshwater fishes $\left(2^{\text {nd }}\right.$ ed.). Ithaca, NY: Cornell University Press.

Homer, C.G., Dewitz, J.A., Yang, L., Jin, S., Danielson, P., Xian, G., Coulston, J., Herold, N.D., Wickham, J.D., \& Megown, K. (2015). Completion of the 2011 National Land Cover Database for the conterminous United States-Representing a decade of land cover change information. Photogrammetric Engineering and Remote Sensing, 81,345-354.

Hooten, M.B. \& Hobbs, N.T. (2015). A guide to Bayesian model selection for ecologists. Ecological Monographs, 85, 3-28.

Jeffrey, J.D., Hasler, C.T., Chapman, J.M., Cooke, S.J., \& Suski, C.D. (2015). Linking landscape-scale disturbances to stress and condition of fish: implications for restoration and conservation. Integrative and Comparastive Biology, 55, 618-630.

Joy, J.E. \& Madan, E. (1989). Pathology of black bass hepatic tissue infected with larvae of the tapeworm Proteocephalus ambloplitis. Journal of Fish Biology, 35, 111-118. 
Kellner, K. (2016). jagsUI: A wrapper around 'rjags' to streamline 'JAGS' analyses. R Package version, 1(4), 4.

Khan, R.A. \& Thulin, J. (1991). Influence of pollution on parasites of aquatic animals. Advances in Parasitology, 30, 201-238.

King, K.C., Mclaughlin, J.D., Boily, M., \& Marcogliese, D.J. (2010). Effects of agricultural landscape and pesticides on parasitism in native bullfrogs. Biological Conservation, 143, 302-310.

Kumar, R., Pande, V., Singh, L., Sharma, L., Saxena, N., Thakuria, D., Singh, A.K., \& Sahoo, P.K. (2016). Pathological findings of experimental Aeromonas hydrophila infection in golden Mahseer (Tor putitora). Fisheries and Aquaculture Journal, 7, 1-6.

Laetz, C.A., Baldwin, D.H., Hebert, V.R., Stark, J.D., \& Scholz, N.L. (2014). Elevated temperatures increase the toxicity of pesticide mixtures to juvenile coho salmon. Aquatic Toxicology, 146, 38-44.

Lafferty, K.D. (2008). Ecosystem consequences of fish parasites. Journal of Fish Biology, 73, 2083-2093.

Loch, T.P. \& Faisal, M. (2015). Emerging flavobacterial infections in fish: a review. Journal of Advanced Research, 6, 283-300.

Lõhmus, M. \& Björklund, M. (2015). Climate change: what will it do to fish-parasite interactions? Biological Journal of the Linnean Society, 116, 397-411.

Luna, L. (1992). Histopathologic methods and color atlas of special stains and tissue artifacts. American Histolabs, Inc., Gaithersburg, Maryland.

MacKenzie, K., Williams, H.H., Williams, B., McVicar, A.H., \& Siddall, R. (1995). Parasites as indicators of water quality and the potential use of helminth transmission in marine pollution studies. Advances in Parasitology, 35, 87-144.

Mantyka-Pringle, C.S., Martin, T.G., Moffatt, D.B., Linke, S., \& Rhodes, J.R. (2014). Understanding and predicting the combined effects of climate change and land-use change on freshwater macroinvertebrates and fish. Journal of Applied Ecology, 51, 572581.

Marcogliese, D.J. (2001). Implications of climate change for parasitism of animals in the aquatic environment. Canadian Journal of Zoology, 79, 1331-1352.

Matthiessen, P., Wheeler, J.R., \& Weltje, L. (2018). A review of the evidence for endocrine disrupting effects of current-use chemicals on wildlife populations. Critical Reviews in Toxicology, 48, 195-216. 
Miller, J.H. (1954). Studies on the life history of Posthodiplostomum minimum (MacCallum 1921). Journal of Parasitology, 40, 255-270.

Molina, M.C., Roa-Fuentes, C.A., Zeni, J.O., \& Casatti, L. (2017). The effects of land use at different spatial scales on instream features in agricultural streams. Limnologica, 65, 1421.

Neves, M.P., de Arruda Amorim, J.P., \& Delariva, R.L. (2018). Influence of land use on the health of a detritivorous fish (Ancistrus mullerae) endemic to the Iguassu ecoregion: relationship between agricultural land use and severe histopathological alterations. Environmental Science and Pollution Research, 25, 11670-11682.

Pietrock, M. \& Marcogliese, D.J. (2003). Free-living endohelminth stages: at the mercy of environmental conditions. TRENDS in Parasitology, 19, 293-299.

R Core Team. (2017). R: A Language and Environment for Statistical Computing. Vienna, Austria: R Foundation for Statistical Computing. URL https://www.R-project.org/.

Rohr, J.R., Schotthoefer, A.M., Raffel, T.R., Carrick, H.J., Halstead, N., Hoverman, J.T., Johnson, C.M., Johnson, L.B., Lieske, C., Piwoni, M.D., Schoff, P.K., \& Beasley, V.R. (2008). Agrochemicals increase trematode infections in a declining amphibian species. Nature, 455, 1235-1240.

Schall, M.K., Blazer, V.S., Walsh, H.L., Smith, G.D., Wertz, T., \& Wagner, T. (2018). Spatial and temporal variability of myxozoan parasite, Myxobolus inornatus, prevalence in young of the year smallmouth bass in the Susquehanna River Basin, Pennsylvania. Journal of Fish Diseases, 2018, 1-12.

Shi, P., Zhang, Y., Li, Z., Li, P., \& Xu, G. (2017). Influence of land use and land cover patterns on seasonal water quality at multi-spatial scales. Catena, 151, 182-190.

Smith, G.D., Blazer, V.S., Walsh, H.L., Iwanowicz, L.R., Starliper, C., \& Sperry, A.J. (2015). The effects of disease-related mortality on young-of-the-year smallmouth bass on populations characteristics in the Susquehanna River basin, Pennsylvania and potential implications to conservation of black bass diversity. American Fisheries Society Symposium, 82, 319-332.

Starliper, C., Blazer, V.S., Iwanowicz, L., \& Walsh, H. (2013). Microbial isolates in diseased fishes, primarily smallmouth bass (Micropterus dolomieu), within the Chesapeake Bay drainage in 2009-2011. Proceedings of the West Virginia Academy of Science, 85, 18-32.

Sures, B., Nachev, M., Selbach, C., \& Marcogliese, D.J. (2017). Parasite responses to pollution: what we know and where we go in 'Environmental Parasitology.' Parasites \& Vectors, 1-19. doi: 10.1186/s13071-017-2001-3. 
Susquehanna River Basin Commission. (2017). 2016 nutrients and suspended sediment in the Susquehanna River basin. Publication No. 314. Available at: www.srbc.net.

Thune, R.L., Stanley, L.A., \& Cooper, R.K. (1993). Pathogenesis of gram-negative bacterial infections in warmwater fish. Annual Review of Fish Diseases, 37-68.

Tibshirani, R. (1996). Regression shrinkage and selection via the lasso. Journal of the Royal Statistical Society Series B (Methodological), 58, 267-288.

Walsh, H.L., Blazer, V.S., Iwanowicz, L.R., \& Smith, G. (2012). A redescription of Myxobolus inornatus from young-of-the-year smallmouth bass (Micropterus dolomieu). Journal of Parasitology, 98, 1236-1242.

Walsh, H.L., Blazer, V.S., Smith, G.D., Lookenbill, M., Alvarez, D.A., \& Smalling, K.L. (2018). Risk factors associated with mortality of age-0 smallmouth bass in the Susquehanna River basin, Pennsylvania. Journal of Aquatic Animal Health, 30, 65-80. 


\section{Figures}

Figure 1. Infections of larval cestodes (bold arrows) and digenetic trematodes (thin arrows) in the liver of a young-of-the-year smallmouth bass from the Juniata River in the Susquehanna River drainage.

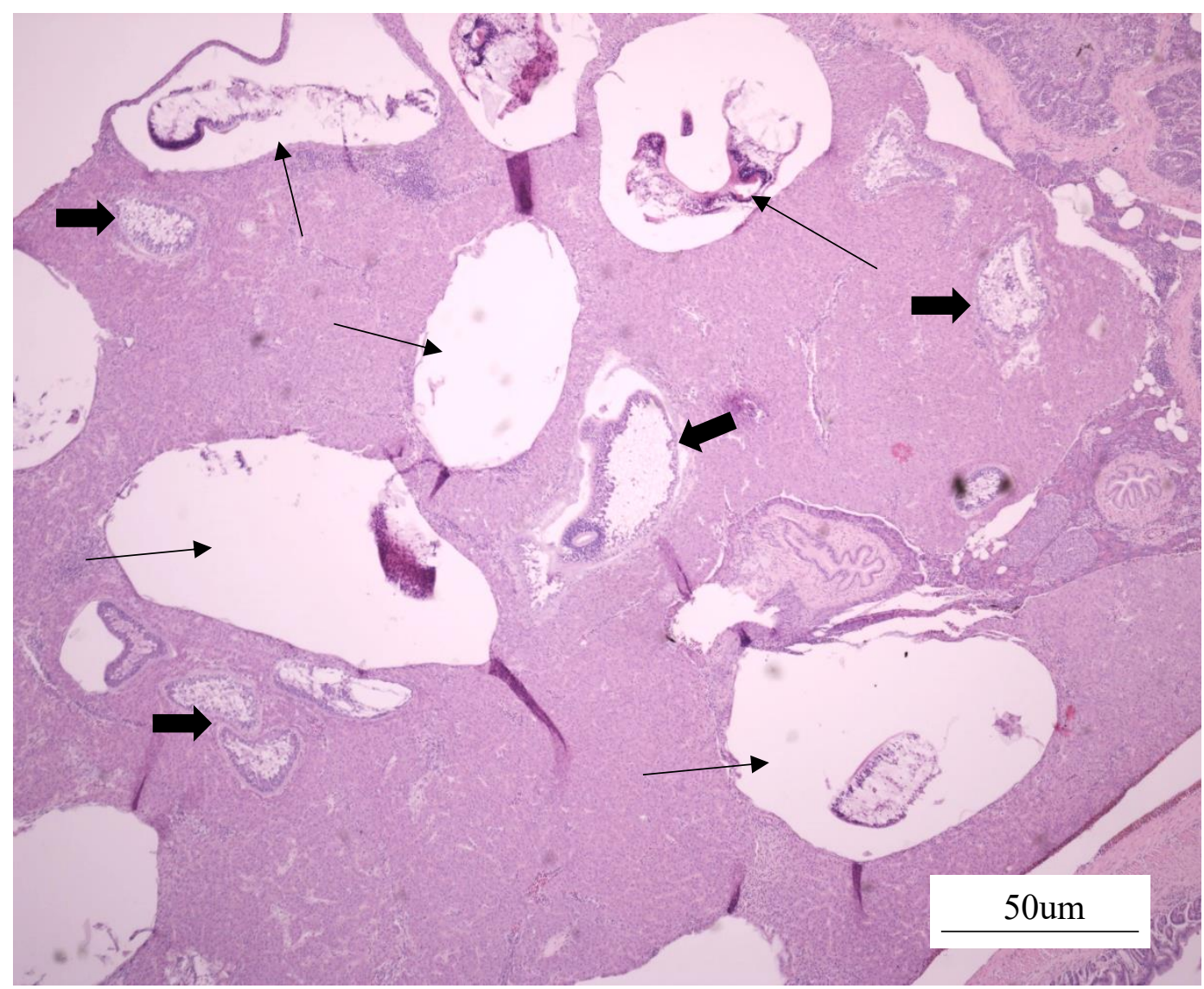


Figure 2. The prevalence of A) coinfections and B) liver helminths in young-of-the-year smallmouth bass (YOY SMB) in the Allegheny, Delaware, Susquehanna, and Potomac River basins from 2013-2016.

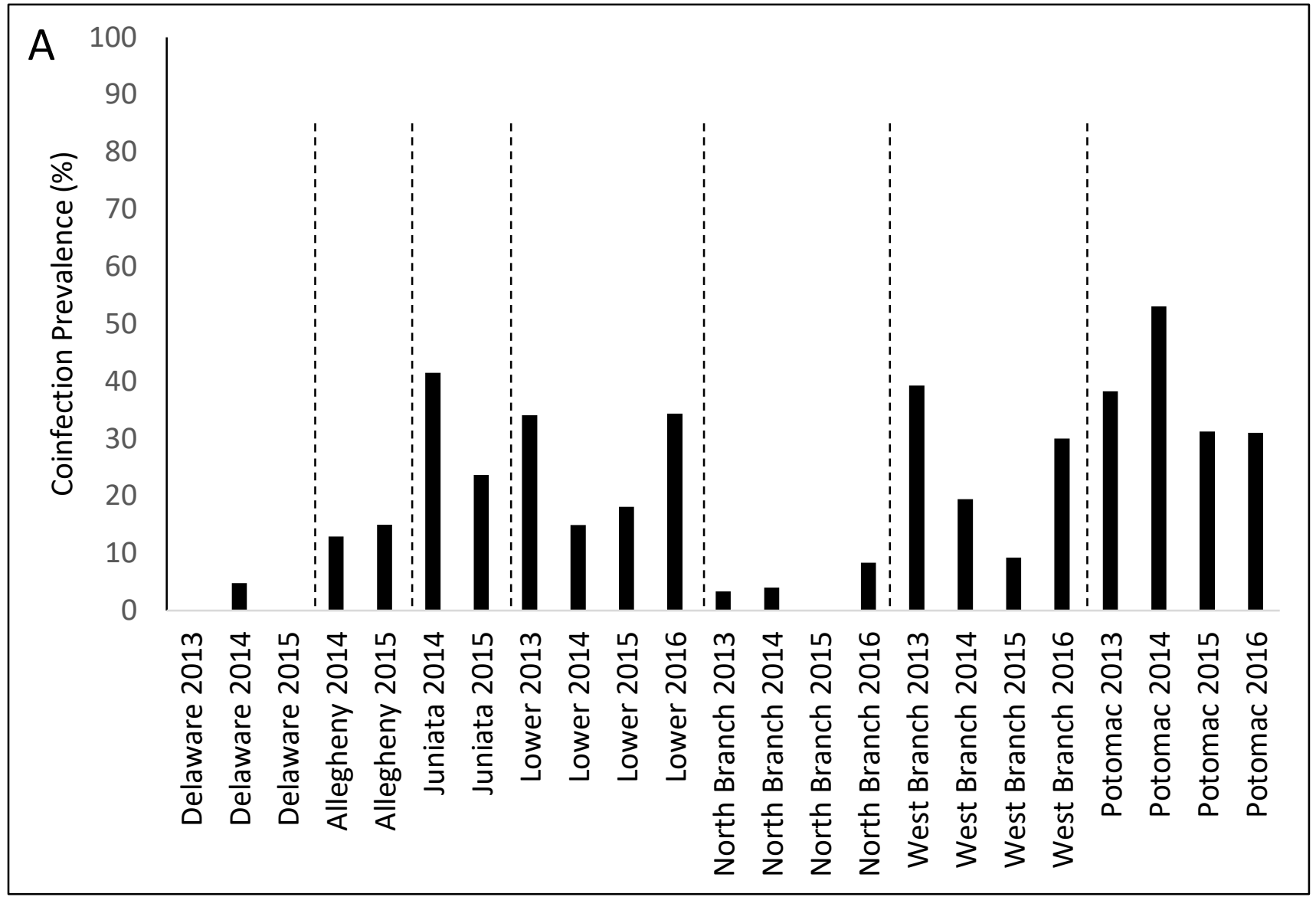




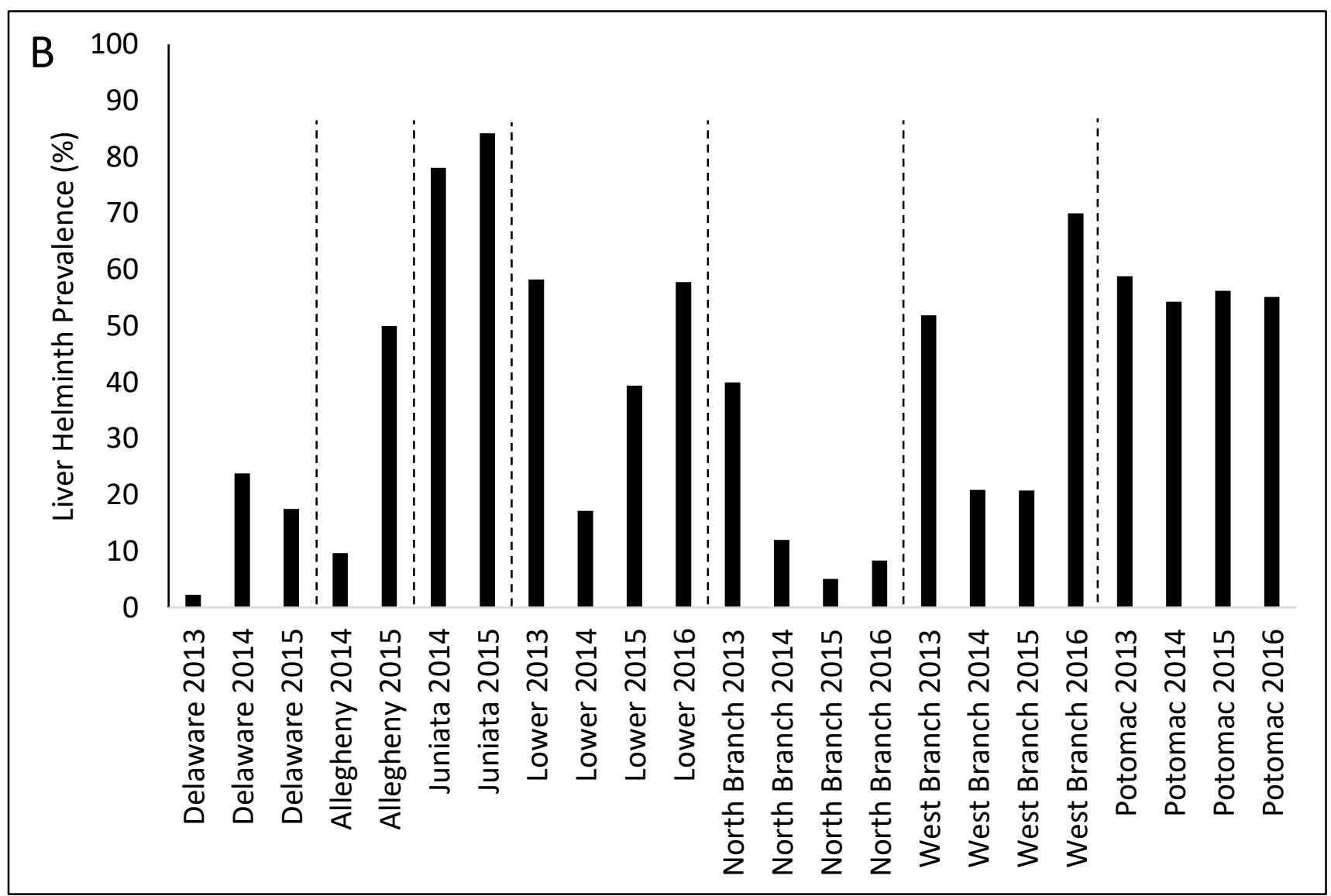


Figure 3. The prevalence of systemic infections, skin lesions, and parasites in young-of-the-year smallmouth bass (YOY SMB) in the Allegheny, Delaware, Susquehanna, and Potomac River basins.

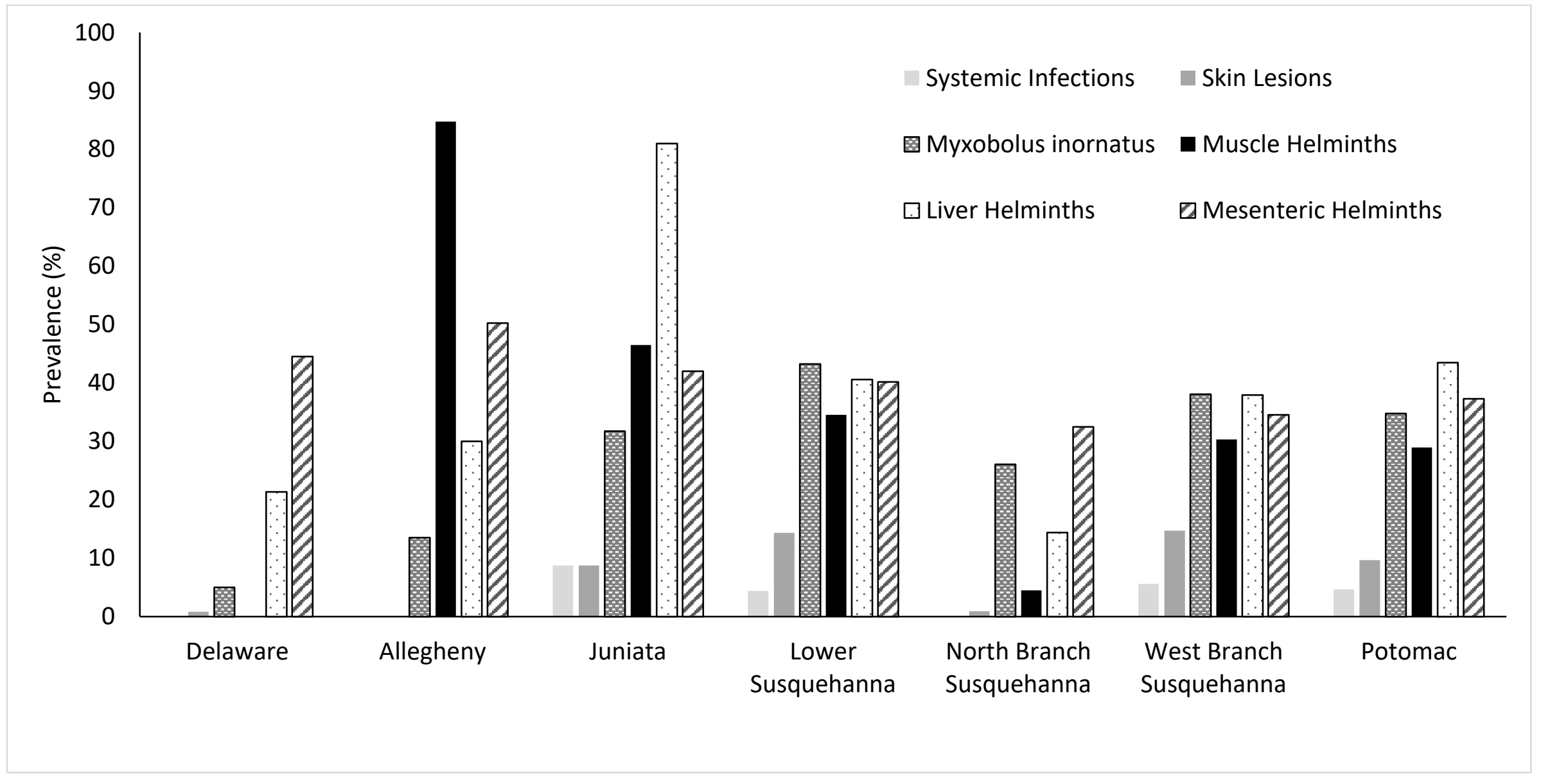


Figure 4. Map of coinfection proportion in young-of-the-year smallmouth bass (YOY SMB) at each site in the Allegheny, Delaware, Susquehanna, and Potomac River basins.

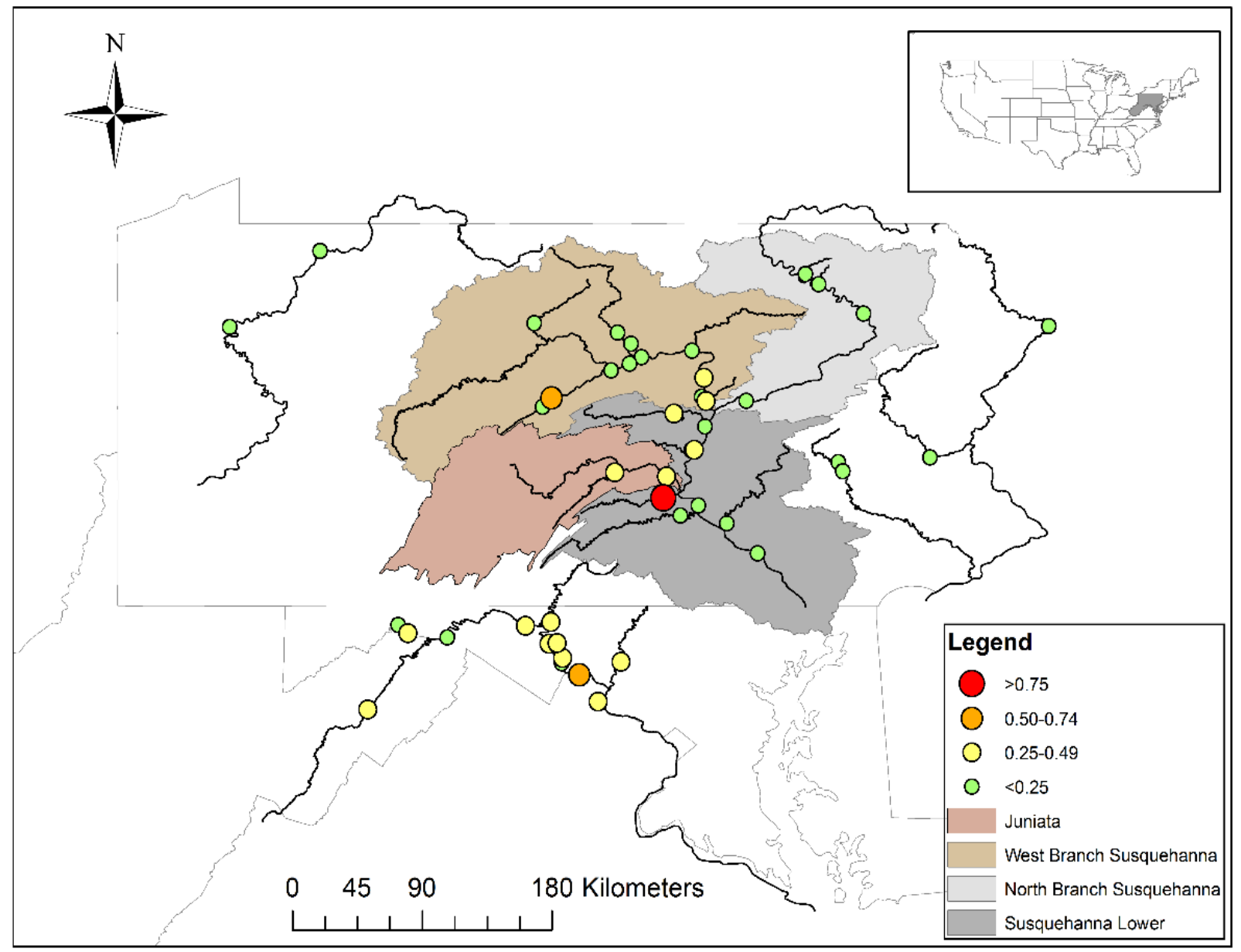


Figure 5. Site specific estimates of coinfection prevalence across 46 sites where young-of-theyear smallmouth bass (YOY SMB) were collected in the Susquehanna River Basin and out of basin sites. Estimates are reported as posterior means and $95 \%$ credible intervals.

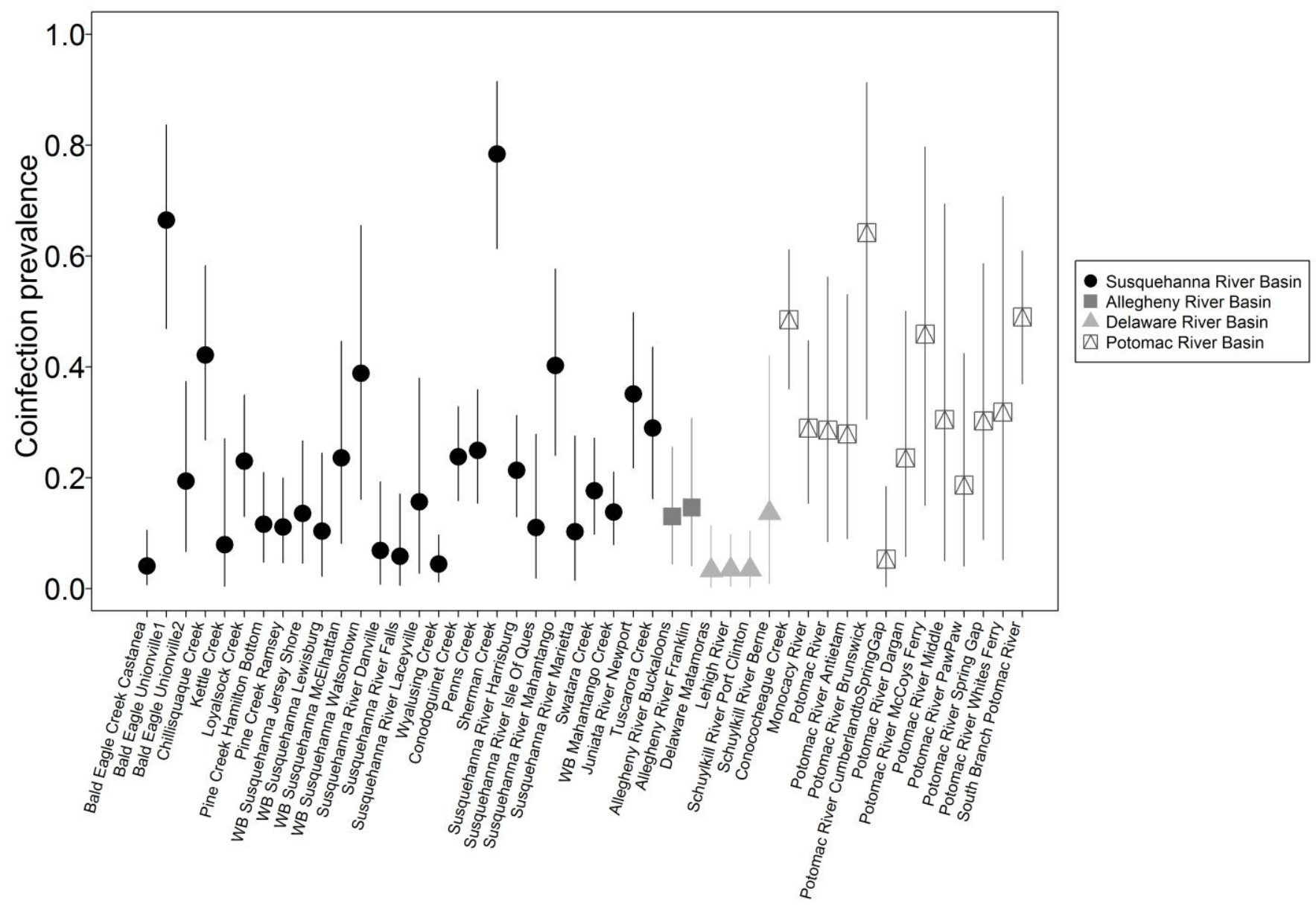

Site 
Figure 6. Predicted relationship between logit transformed coinfection prevalence and logit transformed proportion of agriculture at the National Hydrography Dataset V2+ (NHD) catchment scale for young-of-the-year smallmouth bass (YOY SMB) collected in the Susquehanna River Basin and out of basin sites. The black line and grey shaded area represent the estimated slope from the posterior mean and $95 \%$ credible interval. Site specific estimates are represented by the black circles (posterior mean) and lines (95\% credible intervals).

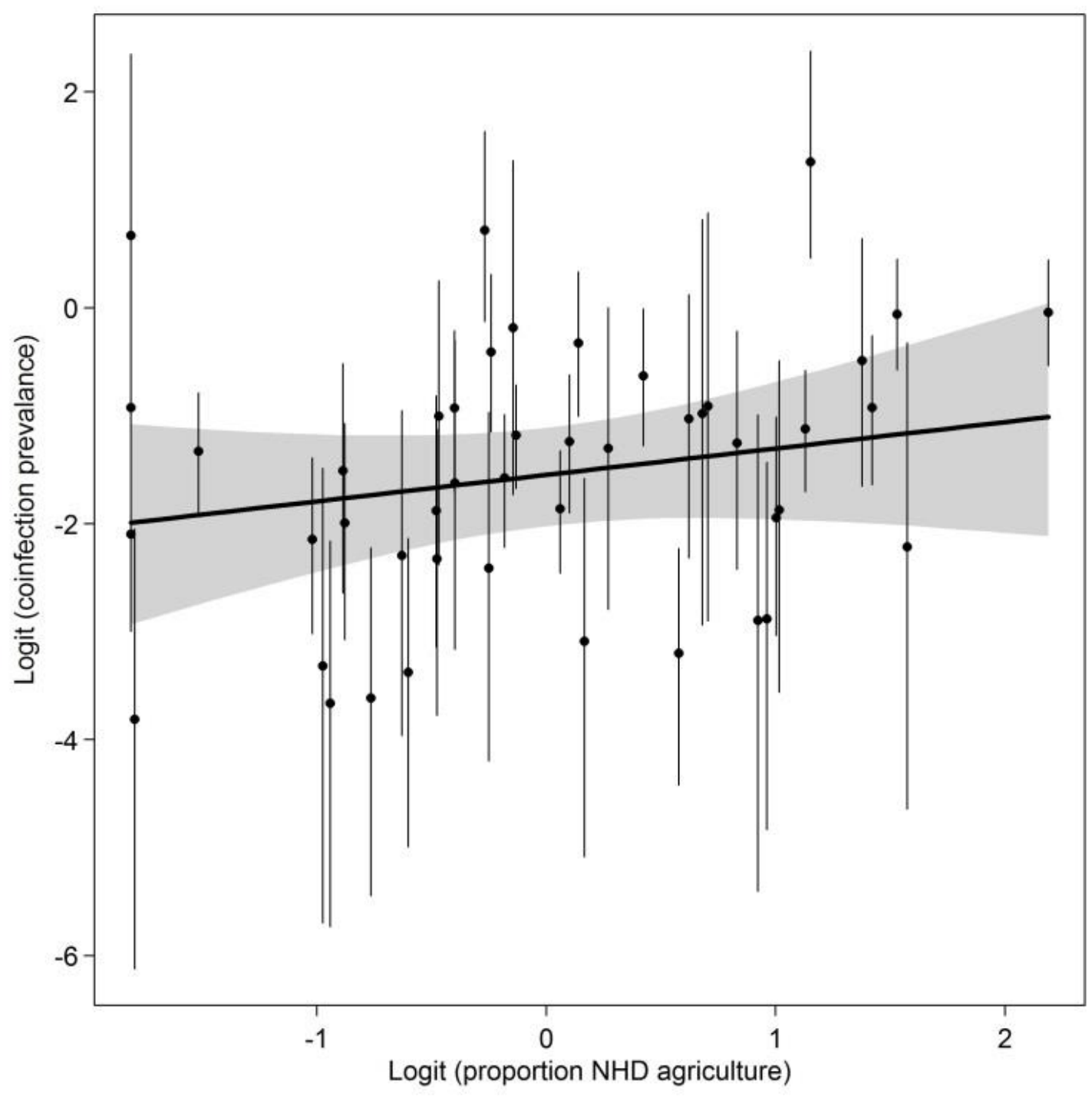


Figure 7. Predicted relationship between logit transformed coinfection prevalence and logit transformed proportion of development at the National Hydrography Dataset V2+ (NHD) catchment scale for young-of-the-year smallmouth bass (YOY SMB) collected in the Susquehanna River Basin and out of basin sites. The black line and grey shaded area represent the estimated slope from the posterior mean and $95 \%$ credible interval. Site specific estimates are represented by the black circles (posterior mean) and lines (95\% credible intervals).

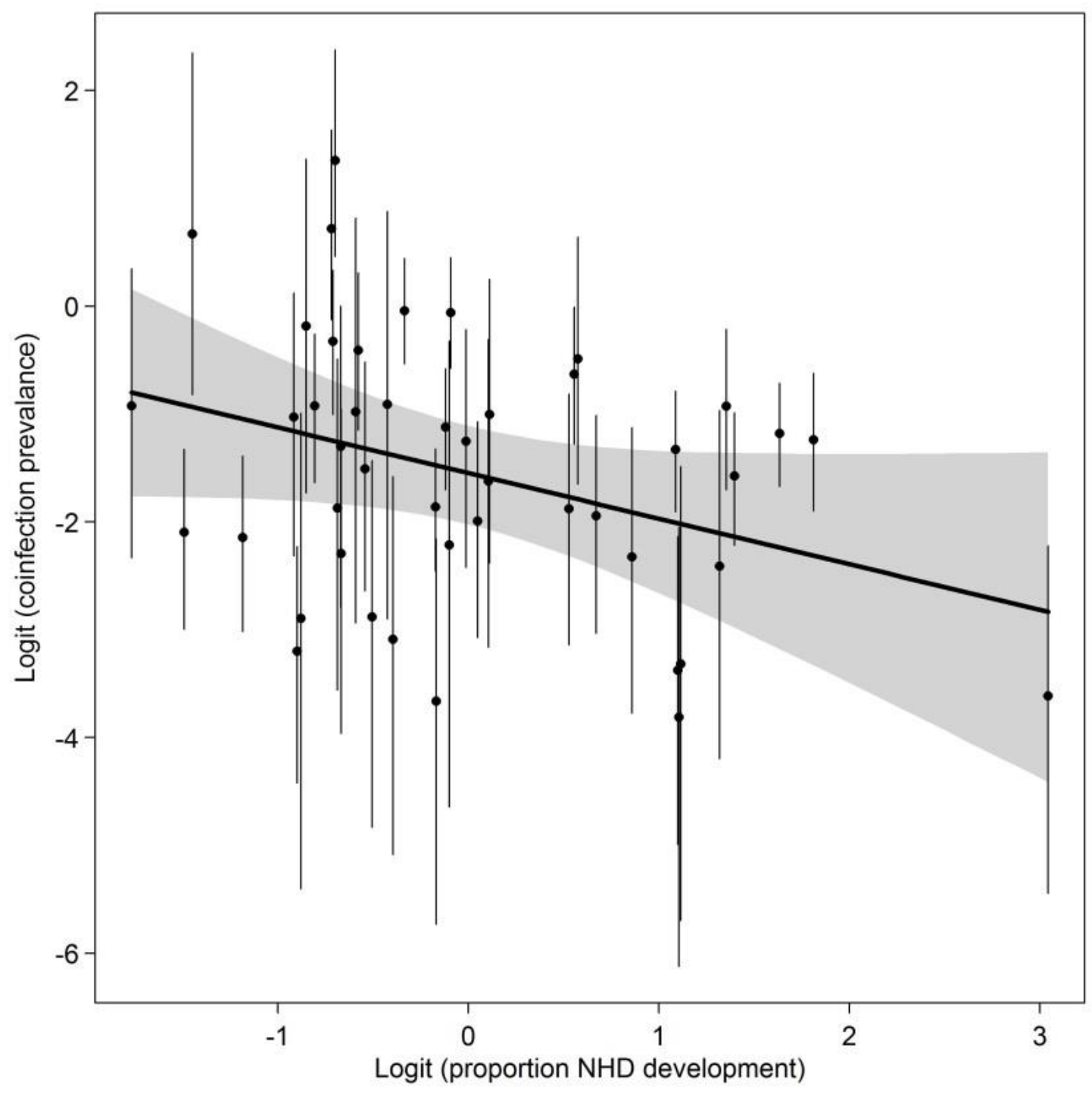


Figure 8. Map of liver helminth proportion in young-of-the-year smallmouth bass (YOY SMB) at each site in the Allegheny, Delaware, Susquehanna, and Potomac River basins.

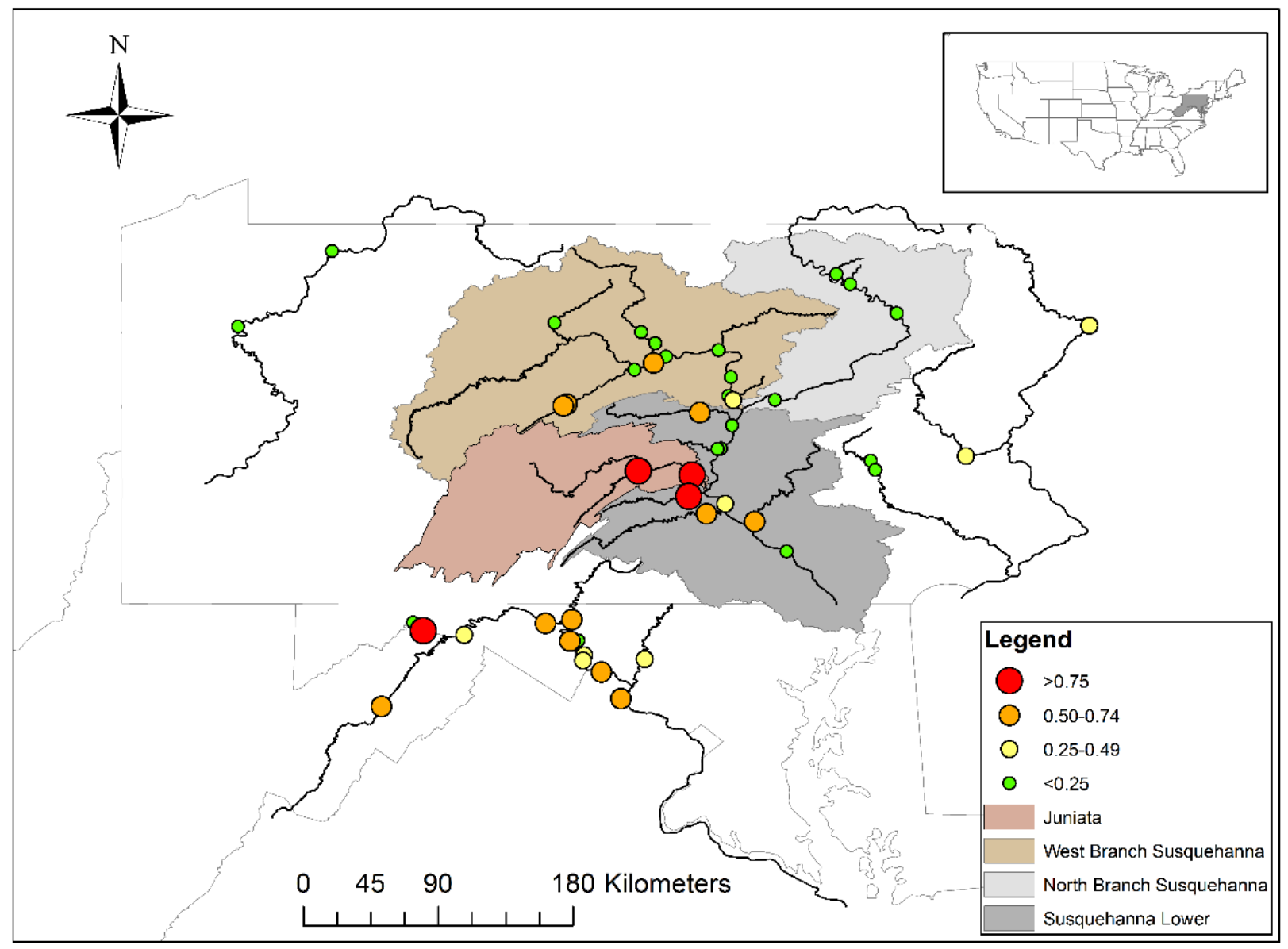


Figure 9. Site specific estimates of liver helminth prevalence across the 46 sample sites where young-of-the-year smallmouth bass (YOY SMB) were collected in the Susquehanna River Basin and out of basin sites. Estimates are reported as posterior means and $95 \%$ credible intervals.

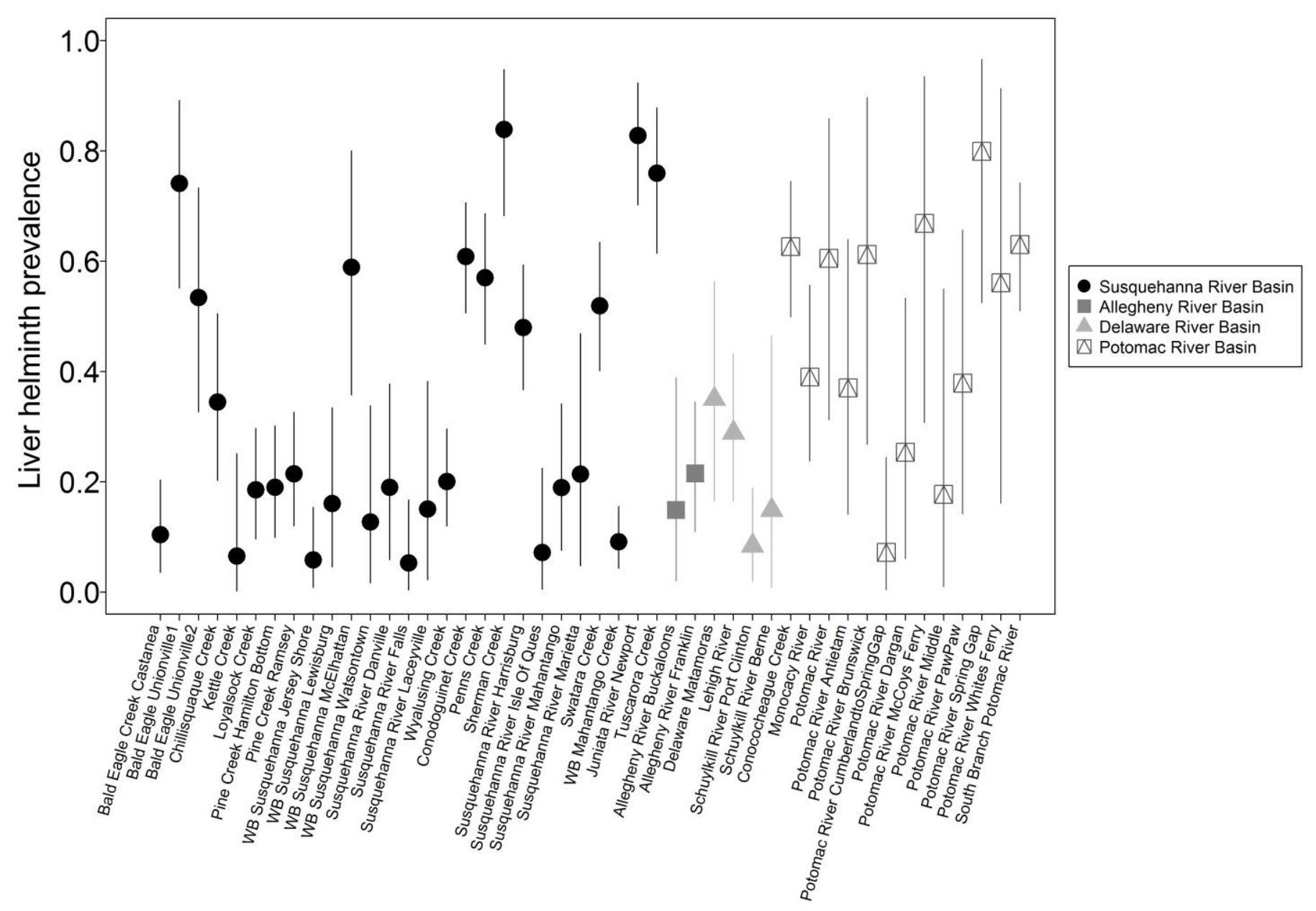

Site 
Figure 10. Predicted relationship between logit transformed cestode prevalence and logit transformed proportion of development at the National Hydrography Dataset V2+ (NHD) catchment scale for young-of-the-year smallmouth bass (YOY SMB) collected in the Susquehanna River Basin and out of basin sites. The black line and grey shaded area represent the estimated slope from the posterior mean and $95 \%$ credible interval. Site specific estimates are represented by the black circles (posterior mean) and lines (95\% credible intervals).

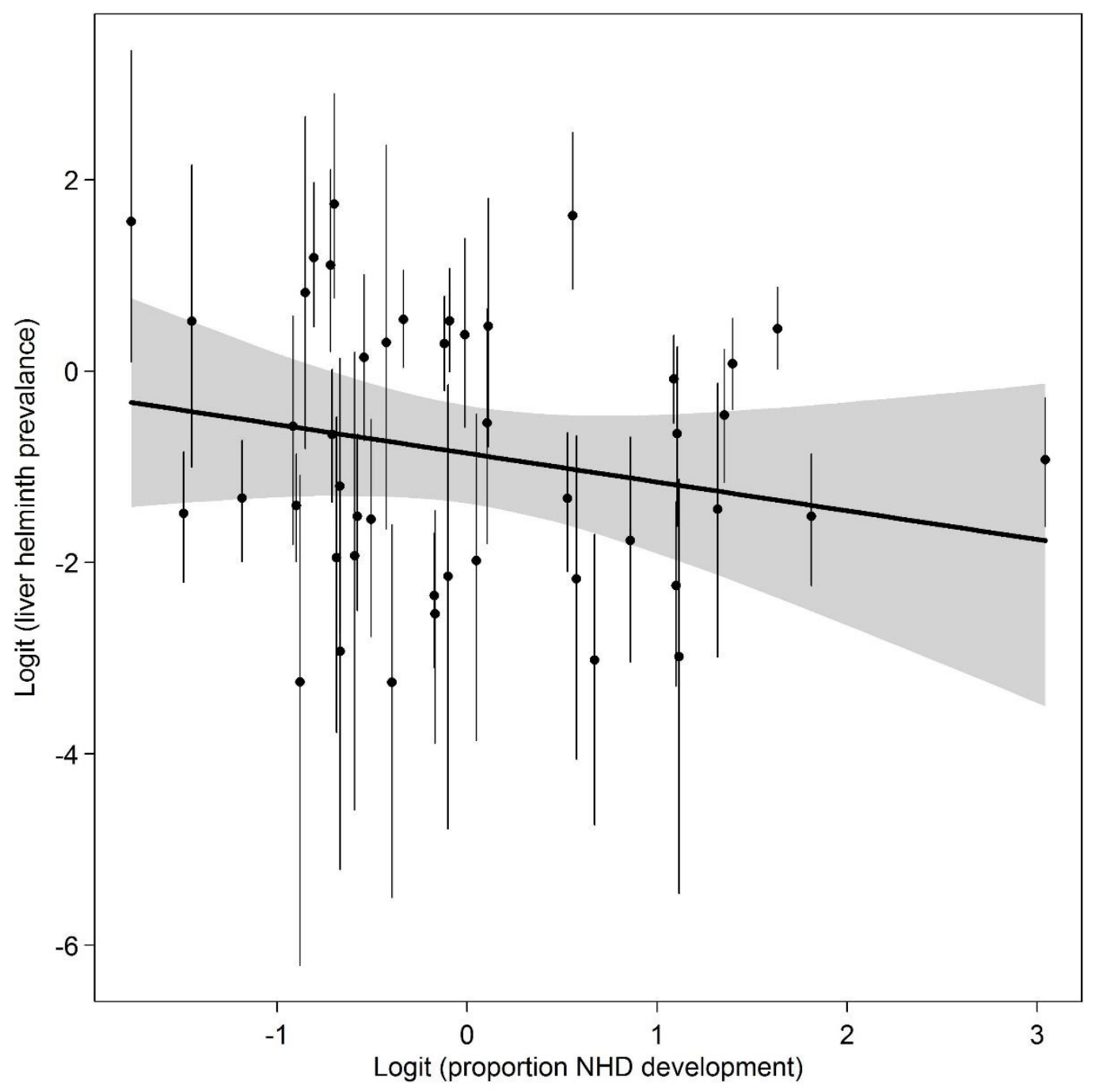


Figure 11. Predicted relationship between logit transformed cestode prevalence and logit transformed proportion of development at the accumulated catchment scale for young-of-theyear smallmouth bass (YOY SMB) collected in the Susquehanna River Basin and out of basin sites. The black line and grey shaded area represent the estimated slope from the posterior mean and $95 \%$ credible interval. Site specific estimates are represented by the black circles (posterior mean) and lines (95\% credible intervals).

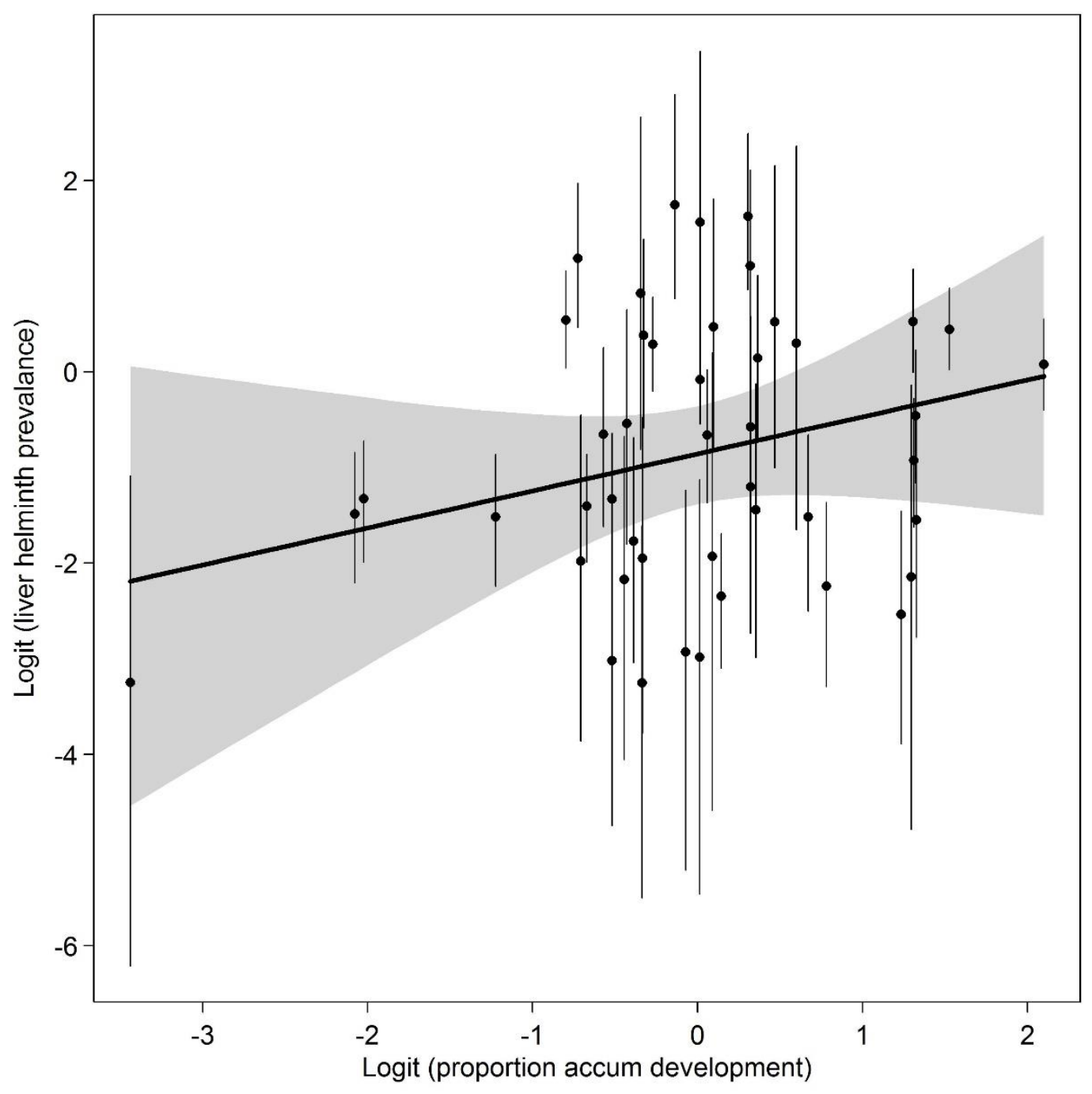




\section{Tables}

Table 1. Prevalence of the parasites and infections included in coinfections in young-of-the-year smallmouth bass (YOY SMB). Fish were sampled from two out-of-basin sites in Pennsylvania (Delaware and Allegheny), four sub-basins in the Susquehanna River basin (Juniata, Lower, North Branch, and West Branch Susquehanna), and the Potomac River basin.

\begin{tabular}{|c|c|c|c|c|c|c|c|c|}
\hline Year & Basin & $\begin{array}{c}\text { \# of Fish } \\
\text { Sampled } \\
\text { (n) } \\
\end{array}$ & $\begin{array}{l}\text { Systemic } \\
\text { Infection } \\
(\%) \\
\end{array}$ & $\begin{array}{l}\text { Skin } \\
\text { Lesion } \\
(\%) \\
\end{array}$ & $\begin{array}{c}\text { Myxobolus } \\
\text { inornatus } \\
(\%) \\
\end{array}$ & $\begin{array}{c}\text { Muscle } \\
\text { Helminth } \\
(\%) \\
\end{array}$ & $\begin{array}{c}\text { Liver } \\
\text { Helminths } \\
(\%) \\
\end{array}$ & $\begin{array}{c}\text { Mesenteric } \\
\text { Helminths } \\
(\%)\end{array}$ \\
\hline 2013 & Delaware & 40 & 0 & 3 & 5 & 0 & 23 & 28 \\
\hline 2014 & Delaware & 21 & 0 & 0 & 10 & 0 & 24 & 76 \\
\hline 2015 & Delaware & 40 & 0 & 0 & 0 & 0 & 18 & 30 \\
\hline 2014 & Allegheny & 31 & 0 & 0 & 7 & 75 & 10 & 76 \\
\hline 2015 & Allegheny & 20 & 0 & 0 & 20 & 95 & 50 & 25 \\
\hline 2014 & Juniata & 41 & 0 & 0 & 38 & 58 & 78 & 49 \\
\hline 2015 & Juniata & 38 & 18 & 18 & 26 & 35 & 85 & 35 \\
\hline 2013 & Lower Susquehanna & 91 & 5 & 22 & 37 & 53 & 54 & 53 \\
\hline 2014 & Lower Susquehanna & 134 & 6 & 14 & 36 & 24 & 18 & 33 \\
\hline 2015 & Lower Susquehanna & 117 & 3 & 14 & 48 & 38 & 38 & 30 \\
\hline 2016 & Lower Susquehanna & 128 & 4 & 8 & 52 & 23 & 51 & 44 \\
\hline 2013 & $\begin{array}{l}\text { North Branch } \\
\text { Susquehanna } \\
\text { North Branch }\end{array}$ & 30 & 0 & 0 & 10 & 5 & 33 & 48 \\
\hline 2014 & $\begin{array}{l}\text { Susquehanna } \\
\text { North Branch }\end{array}$ & 25 & 0 & 0 & 36 & 8 & 12 & 12 \\
\hline 2015 & $\begin{array}{l}\text { Susquehanna } \\
\text { North Branch }\end{array}$ & 59 & 0 & 4 & 25 & 5 & 5 & 37 \\
\hline 2016 & $\begin{array}{l}\text { Susquehanna } \\
\text { West Branch }\end{array}$ & 12 & 0 & 0 & 33 & 0 & 8 & 33 \\
\hline 2013 & $\begin{array}{l}\text { Susquehanna } \\
\text { West Branch }\end{array}$ & 79 & 1 & 0 & 31 & 36 & 44 & 57 \\
\hline 2014 & Susquehanna & 139 & 6 & 14 & 42 & 41 & 19 & 29 \\
\hline
\end{tabular}




\begin{tabular}{|lccccccc|}
2015 & $\begin{array}{c}\text { West Branch } \\
\text { Susquehanna }\end{array}$ & 130 & 0 & 0 & 35 & 29 & 19 \\
2016 & $\begin{array}{l}\text { West Branch } \\
\text { Susquehanna }\end{array}$ & 20 & 15 & 45 & 45 & 15 & 70 \\
2013 & Potomac & 68 & 2 & 4 & 34 & 26 & 64 \\
2014 & Potomac & 81 & 0 & 3 & 46 & 35 & 56 \\
2015 & Potomac & 45 & 0 & 0 & 33 & 44 & 47 \\
2016 & Potomac & 29 & 0 & 0 & 61 & 36 & 54 \\
\hline
\end{tabular}


Table 2. Mean, min, and max land use in each basin and sub-basin. Agricultural and developed land use was analyzed at two spatial scales including accumulated catchment (devAccum and agAccum) and local NHD catchment (devNHD and $a g N H D)$.

\begin{tabular}{|c|c|c|c|c|}
\hline & Basin & Mean & Min & Max \\
\hline \multirow{7}{*}{ devAccum } & Allegheny & 0.046 & 0.042 & 0.047 \\
\hline & Delaware & 0.113 & 0.045 & 0.133 \\
\hline & Juniata & 0.059 & 0.041 & 0.076 \\
\hline & Lower & 0.101 & 0.054 & 0.200 \\
\hline & North Branch & 0.059 & 0.043 & 0.134 \\
\hline & West Branch & 0.047 & 0.008 & 0.099 \\
\hline & Potomac & 0.085 & 0.040 & 0.133 \\
\hline \multirow{7}{*}{$\operatorname{devNHD}$} & Allegheny & 0.233 & 0.153 & 0.250 \\
\hline & Delaware & 0.487 & 0.119 & 0.884 \\
\hline & Juniata & 0.157 & 0.049 & 0.257 \\
\hline & Lower & 0.303 & 0.058 & 0.562 \\
\hline & North Branch & 0.056 & 0.042 & 0.090 \\
\hline & West Branch & 0.211 & 0.009 & 0.615 \\
\hline & Potomac & 0.168 & 0.000 & 0.478 \\
\hline \multirow{7}{*}{ agAccum } & Allegheny & 0.173 & 0.151 & 0.178 \\
\hline & Delaware & 0.119 & 0.109 & 0.130 \\
\hline & Juniata & 0.208 & 0.200 & 0.216 \\
\hline & Lower & 0.335 & 0.220 & 0.489 \\
\hline & North Branch & 0.348 & 0.287 & 0.450 \\
\hline & West Branch & 0.160 & 0.047 & 0.641 \\
\hline & Potomac & 0.296 & 0.111 & 0.531 \\
\hline \multirow{7}{*}{$a g N H D$} & Allegheny & 0.077 & 0.046 & 0.084 \\
\hline & Delaware & 0.064 & 0.000 & 0.551 \\
\hline & Juniata & 0.364 & 0.233 & 0.505 \\
\hline & Lower & 0.168 & 0.010 & 0.425 \\
\hline & North Branch & 0.281 & 0.180 & 0.386 \\
\hline & Potomac & 0.390 & 0.000 & 0.721 \\
\hline & West Branch & 0.137 & 0.000 & 0.492 \\
\hline
\end{tabular}


Table 3. Model estimates for site random effects $\left(\sigma_{\delta}\right)$ and land use coefficients $\left(\beta_{1} \ldots, \beta_{4}\right)$ from the hierarchical logistic regression model used to model young-of-the-year smallmouth bass (YOY SMB) disease characteristics (coinfection or liver helminth prevalence) in the Susquehanna River Basin and out-of-basin sites. Results are reported as posterior mean and 95\% credible intervals except for probability which is the probability that the posterior distribution is in the direction of the posterior mean (slope estimate). NHD= local scale defined by the National Hydrography Dataset V2+ catchment, Accum= accumulated catchment scale defined by the summation of land use in all upstream catchments, $\mathrm{Ag}=$ agriculture, and Dev=development.

\begin{tabular}{|c|c|c|}
\hline Variance components & \multicolumn{2}{|c|}{ Posterior mean $(95 \% \mathrm{CI})$} \\
\hline Site $\left(\sigma_{\delta}\right)$ & \multicolumn{2}{|c|}{$\begin{array}{c}\text { Coinfection Prevalence } \\
1.313(0.931,1.823)\end{array}$} \\
\hline \multirow{2}{*}{$\begin{array}{c}\text { Site }\left(\sigma_{\delta}\right) \\
\text { Land use variables }\end{array}$} & \multicolumn{2}{|c|}{$\begin{array}{c}\text { Liver Helminth Prevalence } \\
1.578(1.161,2.130)\end{array}$} \\
\hline & Slope posterior mean $(95 \% \mathrm{CI})$ & Probability \\
\hline & \multicolumn{2}{|c|}{ Coinfection Prevalence } \\
\hline NHD Ag $\left(\beta_{1}\right)$ & $0.245(-0.199,0.689)$ & 0.86 \\
\hline NHD Dev $\left(\beta_{2}\right)$ & $-0.423(-0.914,0.049)$ & 0.96 \\
\hline $\operatorname{Accum} \operatorname{Ag}\left(\beta_{3}\right)$ & $0.194(-0.313,0.730)$ & 0.77 \\
\hline \multirow[t]{2}{*}{ Accum Dev $\left(\beta_{4}\right)$} & $0.139(-0.442,0.722)$ & 0.69 \\
\hline & \multicolumn{2}{|c|}{ Liver Helminth Prevalence } \\
\hline NHD Ag $\left(\beta_{1}\right)$ & $0.008(-0.507,0.510)$ & 0.51 \\
\hline NHD Dev $\left(\beta_{2}\right)$ & $-0.300(-0.843,0.222)$ & 0.87 \\
\hline $\operatorname{Accum~Ag}\left(\beta_{3}\right)$ & $0.030(-0.558,0.630)$ & 0.55 \\
\hline Accum Dev $\left(\beta_{4}\right)$ & $0.387(-0.255,1.047)$ & 0.88 \\
\hline
\end{tabular}




\title{
Chapter Five: The Effects of Tissue Fixation on Nucleic Acids from Laser Capture Microdissection Tissue Samples of a Teleost
}

\begin{abstract}
As bioindicators of environmental change, wild fish are often microscopically examined to identify disease. Laser capture microdissection (LCM) is a microscopic tool to isolate specific cells or cell populations to identify processes responsible for disease. In an effort to determine the optimal fixation time and fixative type for use in wild fish studies with LCM, liver from smallmouth bass was fixed in three different fixatives for multiple time periods. Pieces of liver were fixed in either Z-Fix (ZF), 10\% neutral buffered formalin (NBF) or PAXgene (PG) for 24 $\mathrm{hr}, 48 \mathrm{hr}$, one week, and two weeks. Tissues were subsequently processed for routine histology and paraffin embedded. Tissue sections were applied to PEN membrane slides, a small section of liver was cut with LCM, and RNA and DNA were extracted. Nucleic acids were quantified with a Qubit® fluorometer and assessed for degradation on an Agilent 2100 Bioanalyzer. Samples that were fixed in PG for $48 \mathrm{hr}$ had the highest mean concentration of RNA and the highest mean concentration of DNA at $48 \mathrm{hr}$ and two weeks. Transcript and DNA abundance analyses were also examined with ZF and NBF extracted nucleic acid samples. Two methods, including qPCR and the Nanostring nCounter ${ }^{\circledR}$, were used to quantify the abundance of DNA and mRNA. Although there were differences in DNA and RNA concentrations between liver samples in the different fixatives, there was virtually no difference in transcript or DNA abundance, making Z-Fix and NBF equally applicable for use with these two molecular techniques. The results of this study verify the use of LCM as a tool to better understand mechanisms of disease in wild fish.
\end{abstract}




\section{Introduction}

Fish histopathology, utilizing formalin-fixed paraffin embedded (FFPE) tissue, is widely used in environmental monitoring and assessment programs and studies (Giltrap et al. 2017; Liebel et al. 2013; Stentiford et al. 2003; Yancheva et al. 2016). More recently molecular techniques, particularly gene expression analyses, are also being utilized in environmental monitoring (Bahamonde et al. 2015; Berninger et al. 2014; Christiansen et al. 2014; Hahn et al. 2016). In mammalian studies the use of formalin fixed, paraffin-embedded (FFPE) tissue has been regarded as a valuable reservoir of preserved nucleic acids (Okello et al., 2010). Many studies have utilized FFPE tissues for exploratory and diagnostic research in cancer (Astolfi et al., 2015; Cotoi et al., 2012; Holley et al., 2012), cellular mutations (Carsillo et al., 2000), parasite infections (Colgrove et al., 2011; Palinauskas et al., 2010) and other disease. Although FFPE tissues provide a vast source of pathologically diverse types of genetic material, it has its drawbacks compared to other tissue preservation methods. Formalin fixation causes nucleic acids to fragment, degrade, and cross-link (Gouveia et al., 2016). For FFPE tissue, optimal time for fixation has been shown to be around $24 \mathrm{hr}$ and longer fixation times, such as one week, have been shown to cause significant degradation to nucleic acids (Gouveia et al., 2016; Lehmann and Kreipe 2001). This degradation results in lower quality and quantity nucleic acids which are significantly fragmented and less likely to be efficiently extracted (Gouveia et al., 2016).

Despite these difficulties, nucleic acids extracted from FFPE tissue have proven to be suitable for use in routine PCR (Ludya et al., 2012), real-time PCR (Bradley et al., 2015; Gloghini et al., 2004), and Next-generation sequencing (Furusato et al., 2008; Hedegaard et al., 2014). Optimization of FFPE tissues for downstream nucleic acid applications has been 
attempted in multiple studies by evaluation of different fixation methods (Matsuda et al., 2011; Peterson et al., 2013), tissue handling and processing times (Chung et al., 2008; Hewitt et al., 2008), and extraction methods (Dedhia et al., 2007; Ludyga et al., 2012; Okello et al., 2010; Senguven et al., 2014).

In aquatic animal monitoring, tissues for microscopic analyses are generally fixed in the field using formalin-based fixatives. Neutral-buffered formalin is the preservation of choice within the medical and research communities due to the excellent preservation of morphology, ability for long periods of storage with few artifacts, minimal tissue shrinkage, ease of storage of paraffin-embedded blocks, and cost-effectiveness (Mathieson et al. 2016). Zinc-based fixatives, such as Z-fix ${ }^{\mathrm{TM}}$ (Anatech LTD, Battle Creek, MI), are still formalin-based and share the same advantages but have been shown to improve the preservation of nucleic acids and proteins in human tissues (Wester et al. 2003). PAXgene, another tissue fixative, was created to eliminate the effects of cross-linking and to improve nucleic acid integrity for downstream molecular analyses (Viertier et al. 2012). It is a two-step/two reagent process in which tissues are first placed in fixative for 2-4 hours and then in a stabilization reagent (Mathieson et al. 2016). For mammalian tissues PAXgene-fixed paraffin embedded tissue sections are comparable to FFPE for morphologic quality and provides good quality RNA from paraffin-embedded tissue (Mathieson et al. 2016; Staff et al. 2013).

For gene expression analyses flash freezing tissue is the "gold standard" for preservation. However, access and transport of dry ice or liquid nitrogen can be difficult in field studies and long-term storage can be an issue. Another nucleic acid preservative is RNAlater ${ }^{\circledR}$ (Ambion, Invitrogen), which rapidly permeates tissue samples to stabilize RNA. Samples in RNAlater ${ }^{\circledR}$ can be stored at room temperature for a week or longer at lower temperatures (Chowdary et al. 
2006). Studies with fishes, incorporating both histopathology and gene expression, most often take a section of an organ preserved in RNAlater (Hahn et al. 2016) or frozen (Lerebours et al. 2013) for gene expression and adjacent sections of the same organ for histopathology.

Drawbacks to this approach are that tissue alterations not visible to the naked eye may be present in one section of an organ but not another and the heterogeneity of cell types is not known for a particular section.

Laser capture microdissection (LCM) utilizes a microscope equipped with a laser which can be used to target specific cells from a heterogeneous population of cells (Emmert-Buck et al. 1996). Single cells or more commonly groups of cells that are abnormal as well as tissue containing parasites or infectious agents can be cut out while the surrounding normal tissue remains on the slide or is cut separately for comparison. The benefit of this is being able to directly analyze the biomolecules from specific populations of cells which is extremely useful in gene expression studies, transcriptome development, or parasite/pathogen identification. Laser capture microdissection has been used extensively in mammalian species for cancer research (Domazet et al., 2008), genetic biomarkers (Morton et al., 2014), forensic (Vandewoestyne and Deforce 2010), and plant cell research (Kerk et al., 2010); however, it has been utilized less frequently in fish-related studies (Fierro-Castro et al., 2015; Nowak et al., 2013; Parhar et al., 2005; Rescan et al., 2013; Viñas and Piferrer 2008). Additionally, the majority of these fish studies have used frozen tissue.

In our laboratory, it can be up to two weeks before field collected fixed tissue is processed for histology. Smallmouth bass are one of the indicator species used for assessing effects of contaminant exposure in our studies. However, they are also a non-model species and hence there is a need for transcriptome information. The aim of this study was to evaluate the 
effects of fixative type and fixation time on the quality and quantity of nucleic acids extracted from fish tissue. In addition to quantifying DNA and RNA, downstream analyses, including Nanostring nCounter® and qPCR, were used to determine if nucleic acids extracted from LCM tissue would have utility in our research. To the best of our knowledge, this is the first time a comparison of NBF, ZF and PG fixatives has been conducted with wild caught fish tissue. Additionally, this is the first time the Nanostring nCounter® technology has been used with formalin fixed LCM tissue from a teleost.

\section{Methods}

Smallmouth Bass Sample Collection

In 2016, three adult SMB were collected by hook and line from a pond at the U.S. Geological Survey Fish Health Laboratory in Kearneysville, West Virginia. Fish were humanely euthanized with a lethal dosage of tricaine methanesulfonate (MS-222, Argent Finquel, Redmond, Washington) and necropsied by incision of a slit from the anus to operculum. The liver was excised and dissected into neutral buffered formalin (NBF) and Z-Fix ${ }^{\mathrm{TM}}(\mathrm{ZF}$; Anatech Ltd, Battle Creek, Michigan). In the spring of 2017, three adult SMB were collected by boat electroshocking by the West Virginia Division of Natural Resources from the Potomac River in Moorefield, West Virginia to obtain samples for fixation in PAXgene Tissue FIX (PG; QIAGEN, Valencia, California).

Histological Preparation and Laser Capture Microdissection 
Samples were fixed for $24 \mathrm{hrs}, 48 \mathrm{hrs,} \mathrm{one} \mathrm{week,} \mathrm{and} \mathrm{two} \mathrm{weeks} \mathrm{at} \mathrm{room} \mathrm{temperature}$ (RT) for NBF and ZF. Tissues preserved in PG were removed from the PAXgene Tissue FIX after $4 \mathrm{hrs}$ at RT, placed in the PAXgene Tissue STABILIZER solution, and stored at $4^{\circ} \mathrm{C}$ for 24 hrs, $48 \mathrm{hrs}$, one week, and two weeks. Tissue processing was performed on a Shandon Citadel $^{\mathrm{TM}}$ Tissue Processor (Thermo Fisher Scientific, Waltham, Massachusettes) as follows: 2 hrs in 65\% ETOH, $1 \mathrm{hr}$ in 80\% ETOH, $1 \mathrm{hr}$ in 95\% ETOH (2x), $1 \mathrm{hr}$ in 100\% ETOH (3x), $1 \mathrm{hr}$ in a 50/50 solution of $100 \%$ ETOH and histoclear (National Diagnostics, Atlanta, Georgia) (2x), 2 hr in histoclear (2x), and $2 \mathrm{hr}$ in paraffin (TissuePrep embedding media, Thermo Fisher) (2x) at $60^{\circ} \mathrm{C}$. Upon completion, tissues were embedded and cooled to harden.

Tissues were sectioned at a thickness of 8-10 $\mu \mathrm{m}$ using a new, sterile blade for each sample and sections placed onto UV-sterilized polyethylene napthalate (PEN) membrane slides (Leica Microsystems, Bannock Burn, Illinois). Diethyl pyrocarbonate (DEPC; Sigma-Aldrich, St. Louis, Missouri) water was used for all steps which required water and slides were allowed to air dry prior to staining.

Tissue sections were de-paraffinized with Pro-Par Clearant (Anatech Ltd) for $45 \mathrm{~s}$ and cleared with $100 \%, 95 \%$, and $70 \% \mathrm{EtOH}$ for $30 \mathrm{~s}$ each. Slides were rinsed in DEPC water for 30 $\mathrm{s}$ and stained with hematoxylin for $2 \mathrm{~min}$. Slides were rinsed in DEPC water for $60 \mathrm{~s}, 70 \% \mathrm{EtOH}$ for $30 \mathrm{~s}$, and counterstained with eosin for 10-15 s. Slides were rinsed again with $95 \%$ and $100 \%$ EtOH for $30 \mathrm{~s}$ and allowed to air dry.

Sections of normal liver were cut at 5x magnification with a Leica LMD6500 microscope (Leica Microsystems) at a pulse rate of 55-60 nm. Sections were cut and dropped into the cap of a sterile microcentrifuge tube by gravity for subsequent extraction of RNA or DNA (Fig. 1A-C). 


\section{Nucleic Acid Extraction and Quantification}

For RNA extractions, the E.Z.N.A.® FFPE RNA Kit (Omega Bio-Tek, Norcross, Georgia) was used according to manufacturer's protocols. Extraction began with the addition of GPL Buffer, skipping the beginning of the protocol since the tissues were already deparaffinized. Samples were digested with proteinase K for 30 min and eluted in $15 \mu$ DEPC water. Samples were quantified with a Qubit ${ }^{\circledR}$ 2.0 Fluorometer using the Qubit $\circledast$ RNA HS Assay Kit. To analyze degradation, RIN scores were obtained with an Agilent RNA 6000 Pico Kit on an Agilent 2100 Bioanalyzer (Agilent Technologies, Santa Clara, California).

DNA was extracted with a proteinase $\mathrm{K}$ digestion buffer (50mM Tris- $\mathrm{HCl}$, pH 8.1, $1 \mathrm{mM}$ EDTA, 0.5\% Tween 20, $0.1 \mathrm{mg} / \mathrm{ml}$ proteinase K) as described in Lehmann and Kreipe (2001). Each sample was extracted in $50 \mu \mathrm{l}$ of proteinase $\mathrm{K}$ digestion buffer and incubated overnight at $55^{\circ} \mathrm{C}$. The tubes were vortexed, centrifuged, and incubated at $95^{\circ} \mathrm{C}$ for $10 \mathrm{~min}$ to deactivate the proteinase $\mathrm{K}$ and stored at $-20^{\circ} \mathrm{C}$. DNA was quantified with a Qubit® 2.0 Fluorometer using the Qubit® dsDNA HS Assay Kit. Samples were analyzed for degradation on a Bioanalyzer with the Agilent High Sensitivity DNA Kit (Agilent Technologies).

For each sample, the concentration of extracted RNA and DNA was standardized by dividing the total concentration by the amount of LCM tissue collected $\left(\mu \mathrm{g} / \mathrm{mm}^{3}\right)$. A KruskalWallis One-Way ANOVA was used to determine if significant differences existed in the concentrations and amount of degradation of DNA and RNA by fixative type and by fixation time. A Pairwise Wilcoxon Rank Sum Test was used to determine differences between groups if the results of the Kruskal-Wallis test were significant.

\section{Molecular Quantification}


To assess the suitability of samples for downstream molecular analyses, quantitative PCR (qPCR) and the nCounter® Sprint (Nanostring Technologies, Seattle, WA) were used. For this portion of the study, only the samples fixed in NBF and ZF were used since samples fixed in PG were from different fish and therefore not suitable for use in transcript abundance comparisons. For qPCR, a 104bp fragment of the smallmouth bass elongation factor 1 alpha (EF1a) gene was targeted in genomic DNA (gDNA) with the EF1a forward (5'-

AAACTGAAGGCAGAGCGTGA-3') and reverse primer (5'-CTGTGTCCAGGGGCATCAAT3') set. The standard was made with PCR product of gDNA amplified with routine PCR with the EF1a primer set under the following conditions: denaturation at $95^{\circ} \mathrm{C}$ for $3 \mathrm{~min}$, followed by 34 cycles of $95^{\circ} \mathrm{C}$ for $30 \mathrm{~s}, 57^{\circ} \mathrm{C}$ for $30 \mathrm{~s}$, and $72^{\circ} \mathrm{C}$ for $1 \mathrm{~min} 30 \mathrm{~s}$, with a final extension at $72^{\circ} \mathrm{C}$ for $5 \mathrm{~min}$. The reaction consisted of $8.5 \mu 1$ nuclease free water, $12.5 \mu \mathrm{l}$ Go Taq Master Mix (Promega, Madison, Wisconsin), $1.0 \mu \mathrm{l}$ of each primer at $10 \mu \mathrm{m}$, and $2.0 \mu \mathrm{l}$ template.

Routine PCR was performed with the FFPE LCM samples with the previously mentioned reaction and amplification conditions, in addition to a negative control. PCR product was cleaned with the QIAquick® PCR purification kit (Qiagen), eluted in $30 \mu 1$ Buffer EB, and incubated for 2 min prior to centrifugation. The purified PCR product was used as template for qPCR and was run at the stock concentration and at a 1:10,000 dilution on a Rotor Gene Q realtime PCR cycler (Qiagen). Prior to the use of amplicons as template, the amount of DNA in the samples fell below the limit of detection. The qPCR reaction consisted of $7.5 \mu 1$ GoTaq ${ }^{\circledR}$ qPCR Master Mix (Promega, Madison, Wisconsin), $1.5 \mu 1$ nuclease free water, $1.5 \mu 1$ of each primer at $10 \mu \mathrm{m}$, and $3 \mu 1$ of template. The standard curve was run in triplicate on a logarithmic scale that ranged from 10-100,000,000 copies in addition to a no-template control. The limit of detection was 10 copies. Samples were run in duplicate and amplified with the EF1a primer set under the 
following conditions: initial denaturation for $10 \mathrm{~min}$ at $95^{\circ} \mathrm{C}$ followed by 39 cycles at $95^{\circ} \mathrm{C}$ for $10 \mathrm{~s}, 60^{\circ} \mathrm{C}$ for $30 \mathrm{~s}$, and $72^{\circ} \mathrm{C}$ for $20 \mathrm{~s}$. A final gradient step was included with a high temperature of $95^{\circ} \mathrm{C}$ and low temperature of $72^{\circ} \mathrm{C}$ for $115 \mathrm{~s}$ ramped at $0.2^{\circ} \mathrm{C} / \mathrm{s}$.

An nCounter® Custom CodeSet that targeted 45 transcripts expressed in the liver of smallmouth bass as described in Hahn et al. (2016) was used. Sample setup was carried out according to manufacturer's protocols with $20 \mathrm{ng}$ of total RNA in each sample. Negative

controls were included as part of Nanostring's quality control. In nSolver ${ }^{\mathrm{TM}}$ Analysis Software 3.0.22, the mean plus three standard deviations of the negative controls were subtracted from the counts to reduce background noise. Differences in transcript abundance were analyzed with the Bioconductor package NanoStringDiff (Wang et al. 2018). No amplification step was included in this assay since the amount of RNA was deemed sufficient for analysis as suggested by Nanostring.

\section{Results}

Nucleic Acid Extractions

The amount of LCM tissue cut for extractions ranged from $0.003-0.020 \mathrm{~mm}^{3}$. The mean DNA and RNA concentrations for all fixatives and fixation times are listed in Table 1. Data is presented as the mean \pm standard error of the mean (mean \pm SEM). The highest concentrations of RNA extracted from the livers of smallmouth bass were from tissues fixed in PG for all fixation times (Fig. 2A). The lowest concentrations were extracted from NBF preserved tissues at one $(3.95 \pm 0.69)$ and two weeks $(2.36 \pm 0.53)$. More RNA was extracted from NBF fixed tissue at $24(8.21 \pm 2.85)$ and $48 \mathrm{hr}(10.33 \pm 3.66)$ than from tissues fixed in $\mathrm{ZF}$ for $24 \mathrm{hr}(7.36 \pm$ $0.91)$, one week $(7.10 \pm 1.77)$, and two weeks $(4.39 \pm 0.64)$. From all three fixative types, the 
greatest amount of RNA was extracted from tissues fixed for $48 \mathrm{hr}$. The amount of DNA recovered was much less than RNA, with all mean concentrations below $10 \mu \mathrm{g} / \mathrm{mm}^{3}$ (Fig. 2B). Similar to RNA, the greatest concentrations of DNA were extracted from tissues fixed in PG for all fixation times. Samples fixed in NBF and ZF for $24 \mathrm{hr}(6.53 \pm 0.54$ and $5.69 \pm 0.48$, respectively) had the greatest concentrations of DNA for those two fixative types. For ZF preserved tissues, DNA concentrations decreased with the amount of fixation time $(6.53 \pm 0.54$ $3.02 \pm 0.13)$. However, DNA concentrations from samples fixed in NBF slightly increased from $48 \mathrm{hr}$ to two weeks $(4.40 \pm 0.14-5.27 \pm 0.67)$. The results of the Kruskall-Wallis One-Way ANOVA and Pairwise Wilcoxon Rank Sum Test showed that the concentrations of RNA were significantly greater from PG preserved samples than from samples fixed in NBF $(P$-value $=$ $0.002)$ and ZF ( $P$-value $<0.000)$. The concentrations of DNA were also significantly greater in samples preserved in PG than in samples preserved in NBF $(P$-value $<0.000)$ and ZF $(P$-value $<$ 0.000). There were no significant differences in the concentrations of RNA or DNA between fixation times.

The quality of the extracted RNA was fairly poor with mean RIN scores on average between two and four for all fixation times (Table 1). RIN scores were slightly higher for NBF than PG and ZF, except for the PG samples fixed for two weeks (which was skewed by one sample with a RIN score of 5.2; Fig. 3A). DNA fragment size was also low and ranged between 200-625 bp for all fixation times (Fig. 3B). The average fragment size was greatest in samples fixed in NBF fixed for $48 \mathrm{hr}$, one week, and two weeks. DNA with the smallest fragment sizes were from samples fixed in PG for $48 \mathrm{hr}$, one week, and two weeks. For the samples fixed in both NBF and ZF, fragment size was smallest from $24 \mathrm{hr}$, greatest in the $48 \mathrm{hr}$ and one week samples and then decreased in samples from the two week fixation time. This trend was 
opposite in samples fixed in PG and fragment size was greatest from the $24 \mathrm{hr}$ time and decreased in samples fixed for $48 \mathrm{hr}$, one week, and two weeks. The results of the KruskallWallis One-Way ANOVA and pairwise Wilcoxon Rank Sum Test showed that RNA RIN scores were significantly greater in samples preserved in NBF than in samples preserved in ZF ( $P$-value $=0.002$ ) but not PG. Unlike RNA, fragment size was significantly greater in samples fixed in both NBF $(P$-value $=0.003)$ and ZF $(P$-value $=0.008)$ compared to PG. There were no significant differences in RIN scores or fragment sizes between fixation times.

\section{Molecular Quantification}

Only the $48 \mathrm{hr}$ samples from the ZF and NBF groups were chosen to examine the effects of fixation time and type. These samples were chosen because with wild fish sampling, getting the samples back to the lab for processing within $24 \mathrm{hr}$ is not always feasible, but processing within $48 \mathrm{hr}$ is. Additionally, more RNA was obtained from samples fixed for $48 \mathrm{hr}$ than from samples fixed for any other time period. Three replicates for each fixation type for a total of six samples were used for these assessments with the nCounter ${ }^{\circledR}$ and qPCR.

Results, including the mean, range, and median transcript abundance from the Nanostring nCounter are provided in Table 2. A transcript abundance analysis with NanoStringDiff revealed that no transcripts were differentially expressed between the ZF and NBF fixed samples.

Results of qPCR are shown in Figure 4. Samples from both fixatives had average CT values within close range of each other $(\mathrm{NBF}=11.12$ and $\mathrm{ZF}=10.56)$ and the variance between all the samples was low (0.72). The standard curve had an $\mathrm{R}^{2}$ value of 0.998 and an amplification efficiency of 0.98 . The average melt temperature for the products was $83.5^{\circ} \mathrm{C}$. The dynamic 
range per reaction is shown in Figure 5. Additionally, a melt curve was generated and nonspecific amplification was absent.

\section{Discussion}

In this study, DNA and RNA were successfully extracted from LCM samples of smallmouth bass liver fixed in NBF, ZF, and PG. The results show that PG was the best fixative for the downstream recovery of nucleic acids. PAXgene fixative was developed without formalin and allowed for greater concentrations of nucleic acids to be extracted. Other studies have had similar results with PG (Groelz et al. 2013; Staff et al. 2013) and found that it exceeded formalin fixatives for nucleic acid recovery. In some studies, PG fixed samples even had higher yields and improved RNA quality than samples that were snap-frozen (Korenkova et al. 2016; Viertler et al. 2012). Although PG was the best fixative for nucleic acid preservation in this study, samples fixed in NBF and ZF were successful in qPCR and Nanostring nCounter analyses.

Overall, the recovery of RNA was greater than DNA, particularly for PG preserved samples (Figure 2). This finding was unexpected and is likely attributable to the differences in extraction methods. Many LCM studies utilize single tube extraction methods for DNA (Callagy et al. 2005; Dedhia et al. 2007; Lehmann and Kreipe 2001; Rooney 2005; Shibutani and Uneyama 2005) to avoid the loss of DNA with a spin-column. In the initial setup of this study, kits with spin-columns designed to extract DNA from FFPE samples were tested; however, DNA concentrations were too low to quantify. Additionally, a single-tube extraction method that did not use sodium dodecyl sulfate (SDS) was used since it acts as a PCR inhibitor (Lehmann and Kreipe 2001). Samples fixed in PG had significantly greater concentrations of DNA than samples fixed in NBF or ZF. For NBF and ZF, the highest concentrations of DNA were 
extracted from samples fixed for $24 \mathrm{hr}$. Since longer fixation times in formalin fixatives have been shown to affect the quality of DNA (Srinivasan et al. 2002), it is not surprising that the most DNA was recovered from samples fixed for $24 \mathrm{hr}$. Since PG is not a formalin-based fixative, samples may need the extra time to fix properly and hence $48 \mathrm{hr}$ to two weeks was more suitable.

Similarly, PG fixed samples had significantly greater concentrations of RNA than samples fixed in NBF or ZF. For all three fixatives the best fixation time was $48 \mathrm{hrs}$ and NBF samples had greater RNA concentrations compared to samples fixed in ZF. These results are contrary to what was found in a study by Wester et al. (2003) where samples fixed in zinc-based formalin had greater concentrations of RNA than samples fixed in NBF. For all three fixatives, the lowest concentrations of RNA were isolated from samples fixed for two weeks, which evidence has shown that fixation for longer than one week causes substantial nucleic acid degradation (Gouveia et al. 2016; Lehmann and Kreipe 2001).

Degradation was evident for both DNA and RNA. For RNA, mean RIN scores ranged between two and three. The average RIN scores for PG samples fixed for two weeks were the highest; however, this was due to one outlier with a high RIN score and was not statistically significant. Unlike other studies that have found PG fixed samples to produce better quality RNA (Groelz et al. 2013), it was not evident in this study. Actually, NBF fixed samples had overall RIN scores that were significantly greater than samples fixed in ZF but not PG. For DNA, fragment size ranged between 213-969 bp, which is to be expected from FFPE tissue (Srinivasan et al. 2002). Similar to RNA, samples fixed in NBF had DNA with greater fragment lengths, particularly for samples fixed for $48 \mathrm{hr}$ to two weeks. DNA obtained from samples fixed in NBF and ZF had significantly greater fragment lengths than samples fixed in PG. 
Interestingly, samples left in the PG Tissue Stabilizer for $48 \mathrm{hr}$ to two weeks actually had the most degraded DNA with the smallest fragment sizes. For samples fixed in NBF and ZF, the results show that DNA is less degraded when they are fixed for $48 \mathrm{hr}$ to two weeks. This could be due to insufficient fixation at $24 \mathrm{hr}$ caused by incomplete penetration of the fixative into the tissue, resulting in fixation of only the outer portions of the tissue (Mathieson et al. 2016).

In addition to being able to quantify DNA and RNA extracted from LCM FFPE tissue, it was important to verify that these samples could be used in downstream molecular methods. For these analyses, only samples fixed in ZF and NBF were used since samples fixed in PG were from different fish and inclusion in the transcript abundance analysis would not be appropriate. Again, ZF and NBF samples fixed for $48 \mathrm{hr}$ were used in these analyses since the most RNA was obtained at this time point. DNA was quantified with a qPCR assay with the housekeeping gene EF1a and 45 transcripts were quantified with the Nanostring nCounter®. With qPCR, the average $\mathrm{CT}$ values for $\mathrm{NBF}$ and $\mathrm{ZF}$ samples were within one value of each other and the variance was low between all samples. For transcript abundance analysis, no transcripts were differentially expressed between NBF and ZF; however, the sample size was low ( $\mathrm{n}=3$ per fixative). Overall, the results of qPCR and the transcript abundance analysis were very similar between ZF and NBF samples. Therefore, tissues fixed in either fixative type are suitable for use in these molecular applications.

To summarize, the results of this study show that samples fixed in PG had significantly grearter concentrations of nucleic acids recovered after extraction, but sample degradation was similar between ZF, NBF, and PG. The information and protocol described in this study is important for future wild fish studies, particularly in tumor research and disease. Smallmouth bass are used as indicator species of exposure to estrogenic endocrine disrupting chemicals; 
however, other indicator species such as brown bullhead and white suckers are used due to their high tumor growth rate (Baumann et al. 1996; Blazer et al. 2016). The development of a protocol to obtain a sufficient amount of nucleic acids for downstream molecular methods is essential in order to better understand processes of disease in wild fish. The results obtained in this study provide guidance for the establishment of a protocol that can be used for any species of fish in LCM studies. To further validate the methods presented here, additional fish species will need to be assessed with nucleic acid extractions and molecular methods, including Nanostring nCounter®. Additionally, the use of PG preserved samples should also be tested in downstream molecular analyses to determine its relevancy in nucleic acid abundance analyses and whether it provides better transcript abundance data than ZF or NBF. The use of LCM will allow for a better understanding of the mechanisms behind disease in wild fish and will hopefully provide answers to questions that remained unanswered with histopathology.

\section{References}

Astolfi, A., M. Urbini, V. Indio, M. Nannini, C.G. Genovese, D. Santini, M. Saponara, A. Mandrioli, G. Ercolani, G. Brandi, G. Biasco, and M.A. Pantaleo. 2015. Whole exome sequencing (WES) on formalin-fixed, paraffin-embedded (FFPE) tumor tissue in gastrointestinal stromal tumors (GIST). BMC Genomics 16: 892.

Bahamonde, P.A., M.E. McMaster, M.R. Servos, C.J. Martyniuk, and K.R. Munkittrick. 2015. Molecular pathways associated with the intersex condition in rainbow darter (Ethostoma caeruleum) following exposures to municipal wastewater in the Grand River basin, ON, Canada. Part B. Aquatic Toxicology 159: 302-316.

Baumann, P.C., I.R. Smith, and C.D. Metcalfe. 1996. Linkages between chemical contaminants and tumors in benthic Great Lakes fish. Journal of Great Lakes Research 22: 131-152.

Berninger, J.P., D. Martinović-Weigelt, N. Garcia-Reyero, L Escalon, E.J. Perkins, G.T. Ankley, and D.L. Villenueve. 2014. Using transcriptomic tools to evaluate biological effects across effluent gradients at a diverse set of study sites in Minnesota, USA. Environmental Science and Technology 48: 2404-2412. 
Blazer, V.S., H.L. Walsh, R.P. Braham, C.M. Hahn, P. Mazik, and P.B. McIntyre. 2016. Tumours in white suckers from Lake Michigan tributaries: pathology and prevalence. Journal of Fish Diseases 40:377-393.

Bradley, W.H., K. Eng, M. Le, A.C. Mackinnon, C. Kendziorski, and J.S. Rader. 2015. Comparing gene expression data from formalin-fixed, paraffin embedded tissues and qPCR with that from snap-frozen tissue and microarrays for modeling outcomes of patients with ovarian carcinoma. BMC Clinical Pathology 15:17.

Callagy, G., L. Jackson, and C. Caldas. 2005. Comparative genomic hybridization using DNA from laser capture microdissected tissue. In Graeme I. Murray and Stephanie Curran (Eds.), Laser Capture Microdissection: Methods and Protocols (pp. 39-55). Totowa, New Jersey: Humana Press Inc.

Carsillo, T., A. Astrinidis, and E.P. Henske. 2000. Mutations in the tuberous sclerosis complex gene TSC2 are a cause of sporadic pulmonary lymphangioleiomyomatosis. PNAS 97: 6085-6090.

Chowdary, D., J. Lathrop, J. Skelton, K. Curtin, T. Briggs, Y. Zhang, J. Yu, Y. Wang, and A. Mazumder. 2006. Prognostic gene expression signatures can be measured in tissues collected in RNAlater ${ }^{\circledR}$ preservative. Journal of Molecular Diagnostics 8:31-39.

Christiansen, H.E., A.C. Mehinto, F. Yu, R.W. Perry, N.D. Denslow, A.G. Maule, and M.G. Mesa. 2014. Correlation of gene expression and contaminant concentrations in wild largescale suckers: a field-based study. Science of the Total Environment 484: 379-389.

Chung, J-Y., T. Braunschweig, R. Williams, N. Guerrero, K.M. Hoffmann, M. Kwon, Y.K. Song, S.K. Libutti, and S.M. Hewitt. 2008. Factors in tissue handling and processing that impact RNA obtained from formalin-fixed, paraffin-embedded tissue. Journal of Histochemistry and Cytochemistry 56:1033-1042.

Colgrove, K.M., M.E. Grigg, D. Carlson-Bremer, R.H. Miller, F.M.D. Gulland, D.J.P. Ferguson, D. Rejmanek, and B.C. Barr. 2011. Discovery of three novel coccidian parasites infecting California sea lions (Zalophus californianus), with evidence of sexual replication and interspecies pathogenicity. Journal of Parasitology 97: 868-877.

Cotoi, C.G., S.E. Khorsandi, I.E. Pleşea, and A. Quaglia. 2012. Whole-genome DASL gene expression profiling of hepatocellular carcinoma sub-populations isolated by laser microdissection on formalin-fixed and paraffin-embedded liver tissue samples. Romanian Journal of Morphology and Embryology 53: 893-902.

Dedhia, P., S. Tarale, G. Dhongde, R. Khadapkar, and B. Das. 2007. Evaluation of DNA extraction methods and real time PCR optimization on formalin-fixed paraffin-embedded tissues. Asian Pacific Journal of Cancer prevention 8: 55-59. 
Domazet, B., G.T. MacLennan, A. Lopez-Beltran, R. Montironi, and L. Cheng. 2008. Laser capture microdissection in the genomic and proteomic era: targeting the genetic basis of cancer. International Journal of Clinical and Experimental Pathology. 1: 475-488.

Emmert-Buck, M.R., R.F. Bonner, P.D. Smith, R.F. Chuaqui, Z. Zhuang, S.R. Goldstein, R.A. Weiss, and L.A. Liotta. 1996. Laser capture microdissection. Science 274: 998-1001.

Fierro-Castro, C., M.C. Santa-Cruz, M. Hernández-Sánchez, M. Teles, and L. Tort. 2015. Analysis of steroidogenic pathway key transcripts in interrenal cells isolated by laser microdissection (LMD) in stressed rainbow trout. Comparative Biochemistry and Physiology, Part A 190: 39-46.

Furusato, B. S. Shaheduzzaman, G. Petrovics, A. Dobi, M. Seifert, L. Ravindranath, M.E. Nau, T. Werner, M. Vahey, D.G. McLeod, S. Srivastava, and I.A. Sesterhenn. 2008. Transcriptome analyses of benign and malignant prostate epithelial cells in formalinfixed paraffin-embedded whole-mounted radical prostatectomy specimens. Prostate Cancer and Prostatic Diseases 11: 194-197.

Giltrap, M., J. Ronan, J.P. Bignell, B.P. Lyons, E. Collins, H. Rochford, B. McHugh, E. McGovern, L. Bull and J. Wilson. 2017. Integration of biological effects, fish histopathology and contaminant measurements for the assessment of fish health: A pilot application in Irish marine waters. Marine Environmental Research 129:113-132.

Gloghini, A., B. Canal, U. Klein, L. Dal Maso, T. Perin, R. Dalla-Favera, and A. Carbone. 2004. RT-PCR analysis of RNA extracted from bouin-fixed and paraffin-embedded lymphoid tissues. Journal of Molecular Diagnostics 6: 290-296.

Gouveia, G.R., S.C. Ferreira, S.A.C. Siqueira, and J. Pereira. 2016. Nucleic acids extraction from formalin-fixed and paraffin-embedded tissues. In: M.L. Larramendy and S. Solenski. Nucleic acids - from basic aspects to laboratory tools. InTech. pg. 27-36.

Groelz, D., L. Sobin, P. Branton, C. Compton, R. Wyrich, and L. Rainen. 2013. Non-formalin fixative versus formalin-fixed tissue: a comparison of histology and RNA quality. Experimental and Molecular Pathology 94: 188-194.

Hahn, C.M., L.R. Iwanowicz, R.S. Cornman, P.M. Mazik, and V.S. Blazer. 2016. Transcriptome discovery in non-model wild fish species for the development of quantitative transcript abundance assays. Comparative Biochemistry and Physiology, Part D 20: 27-40.

Hedegaard, J., K. Thorsen, M.K. Lund, A-M.K. Hein, S.J. Hamilton-Dutoit, S. Vang, I. Nordentoft, K. Birkenkamp-Demtröder, M. Kruhøffer, H. Hager, B. Knudsen, C.L. Andersen, K.D. Sørensen, J.S. Pedersen, T.F. Ørntoft, and L. Dyrskjøt. 2014. Nextgeneration sequencing of RNA and DNA isolated from paired fresh-frozen and formalinfixed paraffin-embedded samples of human cancer and normal tissue. PLoS ONE 9: e98187. 
Hewitt, S.M., F.A. Lewis, Y. Cao, R.C. Conrad, M. Cronin, K.D. Danenberg, T.J. Goralski, J.P. Langmore, R.G. Raja, P.M. Williams, J.F. Palma, and J.A. Warrington. 2008. Tissue handling and specimen preparation in surgical pathology. Archives of Pathology and Laboratory Medicine 132: 1929-1935.

Holley, T. E. Lenkiewicz, L. Evers, W. Tembe, C. Ruiz, J.R. Gsponer, C.A. Rentsch, L. Bubendorf, M. Stapleton, D. Amorese, C. Legendre, H.E. Conliffe, A.E. McCullough, B. Pockaj, D. Craig, J. Carpten, D. Von Hoff, C. Iacobuzio-Donahue, and M.T. Barrett. 2012. Deep clonal profiling of formalin fixed paraffin embedded clinical samples. PLoS ONE 7: e50586.

Kerk, N.M., T. Ceserani, S.L. Tausta, I.M. Sussex, and T.M. Nelson. 2010. Laser capture microdissection of cells from plant tissues. Plant Physiology 132: 27-35.

Korenkova, V., J. Slyskova, V. Nonosadova, S. Pizzamiglio, L. Langerova, J. Bjorkman, O. Vycital, V. Liska, M. Levy, K. Veskrna, P. Vodicka, L. Vodickova, M. Kubista, and P. Verderio. 2016. The focus on sample quality: influence of colon tissue collection on reliability of qPCR data. Scientific Reports 6:29023.

Lehmann, U. and H. Kreipe. 2001. Real-time PCR analysis of DNA and RNA extracted from formalin-fixed and paraffin-embedded biopsies. Methods 25: 409-418.

Lerebours, A., J.P. Bignell, G.D. Stentiford, S.W. Feist, B.P. Lyons, and J.M. Rotchell. 2013. Advanced diagnostics applied to fish liver tumours: relating pathology to underlying molecular aetiology. Marine Pollution Bulletin 72: 94-98.

Liebel, S., M.E.M. Tomotake and C.A. Oliveira Ribeiro. 2013. Fish histopathology as biomarker to evaluate water quality. Ecotoxicology and Environmental Contamination 8:9-15.

Ludyga, N., B. Grünwald, O Azimzadeh, S. Englert, H. Höfler, S. Tapio, and M. Aubele. 2012. Nucleic acids from long-term preserved FFPE tissues are suitable for downstream analyses. Virchows Archiv 460: 131-140.

Mathieson, W., N. Marcon, L. Antunes, D.A. Ashford, F. Betsou, S.G. Frasquilho, O.A. Kofanova, S.C. McKay, S. Pericleous, C. Smith, K.M. Unger, C. Zeller, and G.A. Thomas. 2016. American Journal of Clinical Pathology 146: 45-40.

Matsuda, Y., T. Fujii, T. Suzuki, K. Yamahatsu, K. Kawahara, K. Teduka, Y. Kawamoto, T. Yamamoto, T. Ishiwata, and Z. Naito. 2011. Comparison of fixation methods for preservation of morphology, RNAs, and proteins from paraffin-embedded human cancer cell-implanted mouse models. Journal of Histochemistry and Cytochemistry 59: 68-75.

Morton, M.L., X. Bai, C.R. Merry, P.A. Linden, A.M. Khalil, R.S. Leidner, and C.L. Thompson. 2014. Identification of mRNAs and lincRNAs associated with lung cancer progression 
using next-generation RNA sequencing from laser micro-dissected archival FFPE tissue specimens. Lung Cancer 85: 31-39.

Nowak, B., K. Cadoret, S.W. Feist, and T.P. Bean. 2013. Laser-capture dissection and immunohistochemistry reveals chloride and mucous-cell specific gene expression in gills of seawater acclimated Atlantic salmon Salmo salar. Journal of Fish Biology 83: 14591467.

Okello, J.B.A., J. Zurek, A.M. Devault, M. Kuch, A.L. Okwi, N.K. Sewankambo, G.S. Bimenya, D. Poinar, and H.N. Poinar. 2010. Comparison of methods in recovery of nucleic acids from archival formalin-fixed paraffin-embedded autopsy tissues. Analytical Biochemistry 400: 110-117.

Palinauskas, V., O.V. Dolnik, G. Valkiūnas, and S. Bensch. 2010. Laser microdissection microscopy and single cell PCR of avian hemosporidians. Journal of Parasitology 96: 420-424.

Parhar, I.S., S. Ogawa, Y. Sakuma, and H.A. Bern. 2005. Three GnRH receptor types in lasercaptured single cells of the cichlid pituitary display cellular and functional heterogeneity. PNAS 102: 2204-2209.

Peterson, T.S., M.L. Kent, J.A. Ferguson, V.G. Watral, and C.M. Whipps. 2013. Comparison of fixatives, fixation time, and severity of infection on PCR amplification and detection of Mycobacterium marinum and Mycobacterium chelonae DNA in paraffin-embedded Zebrafish (Danio rerio). Diseases of Aquatic Organisms 104: 113-120.

Rescan, P-Y., J. Montfort, A. Fautrel, C. Rallière, and V. Lebret. 2013. Gene expression profiling of the hyperplastic growth zones of the late trout embryo myotome using laser capture microdissection and microarray analysis. BMC Genomics 14: 173.

Rooney, P.H. 2005. Multiplex quantitative real-time PCR of laser microdissected tissue. In Graeme I. Murray and Stephanie Curran (Eds.), Laser Capture Microdissection: Methods and Protocols (pp. 39-55). Totowa, New Jersey: Humana Press Inc.

Sengüven, B., E. Baris, T. Oygur, and M. Berktas. 2014. Comparison of methods for the extraction of DNA from formalin-fixed, paraffin-embedded archival tissues. International Journal of Medical Sciences 11: 494-499.

Shibutani, M. and C. Uneyama. 2005. Methacarn fixation for genomic DNA analysis in microdissected cells. In Graeme I. Murray and Stephanie Curran (Eds.), Laser Capture Microdissection: Methods and Protocols (pp. 39-55). Totowa, New Jersey: Humana Press Inc.

Srinivasan, M., D. Sedmak, and S. Jewell. 2002. Effect of fixatives and tissue processing on the content and integrity of nucleic acids. American Journal of Pathology 161: 1961-1971. 
Staff, S., P. Kujala, R. Karhu, A. Rökman, J. Ilvesaro, S. Kares, and J. Isola. 2013. Preservation of nucleic acids and tissue morphology in paraffin-embedded clinical samples: comparison of five molecular fixatives. Journal of Clinical Pathology 66: 807-810.

Stentiford, G.D., M. Longshaw 2003. Histopathological biomarkers in estuarine fish species for the assessment of biological effects of contaminants. Marine Environmental Research 55:137-159.

Vandewoestyne, M. and D. Deforce. 2010. Laser capture microdissection in forensic research: a review. International Journal of Legal Medicine 124: 513-521.

Viertler, C., D. Groelz, S. Gündisch, K. Kashofer, B. Reischauer, P.H.J. Riegman, R. Winther, R. Wyrich, K-F. Becker, U. Oelmüller, and K. Zatloukal. 2012. A new technology for stabilization of biomolecules in tissues for combined histological and molecular analyses. Journal of Molecular Diagnostics 14: 458-466.

Viñas, J. and F. Piferrer. 2008. Stage-specific gene expression during fish spermatogenesis as determined by laser-capture microdissection and quantitative-PCR in sea bass (Dientrarchus labrax) gonads. Biology of Reproduction 79: 738-747.

Wang, H., T. Zhai, and C. Wang. 2018. NanoStringDiff: differential expression analysis of NanoString nCounter data. R package version 1.10.0.

Wester, K., A. Asplund, H. Bäckvall, P. Micke, A. Derveniece, I. Hartmane, P. Malmström, and F. Pontén. 2003. Zinc-based fixatives improves preservation of genomic DNA and proteins in histoprocessing of human tissues. Laboratory Investigation 83: 889-899.

Yancheva, V., I. Velcheva, S. Stoyanova, and E. Georgieva. 2016. Histological biomarkers in fish as a tool in ecological risk assessment and monitoring programs: a review. Applied Ecology and Environmental Research 14: 47-75. 


\section{Figures}

Figure 1. A) Section of smallmouth bass liver prior to being cut out with laser capture microdissection (LCM), B) after being cut with LCM, and C) section of cut liver in the cap of a microcentrifuge tube prior to nucleic acid extraction.
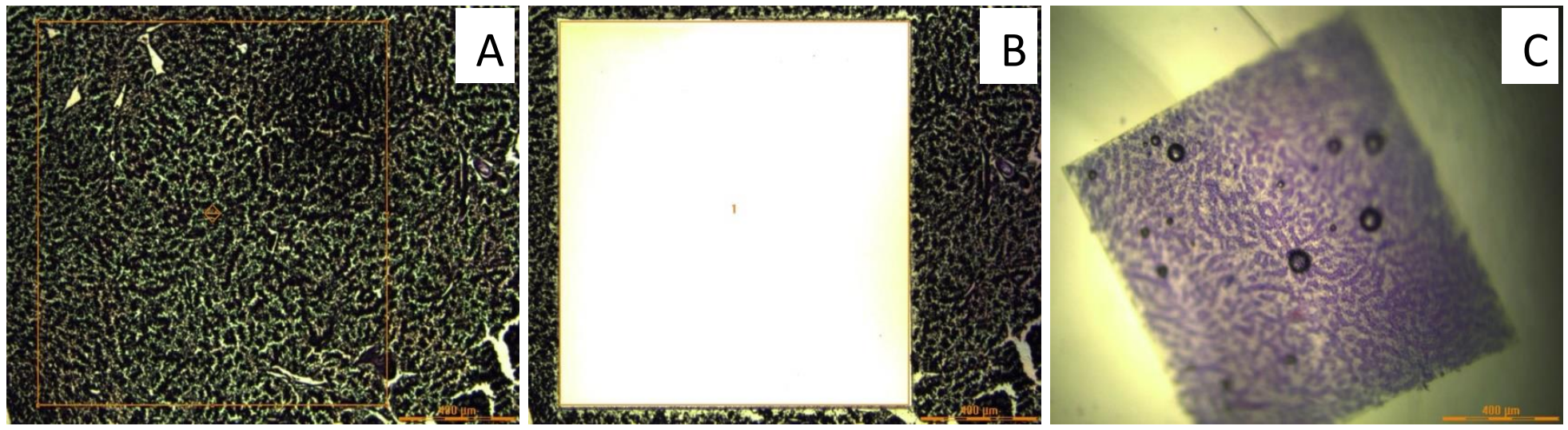
Figure 2. Mean concentration of extracted A) RNA and B) DNA $\left(\mu \mathrm{g} / \mathrm{mm}^{3}\right)$ from FFPE LCM samples of smallmouth bass liver fixed for $24 \mathrm{hr}, 48 \mathrm{hr}$, one week, and two weeks in $10 \%$ neutral buffered formalin (NBF), Z-Fix, and PAXgene fixatives. Error bars represent the standard error of the mean.
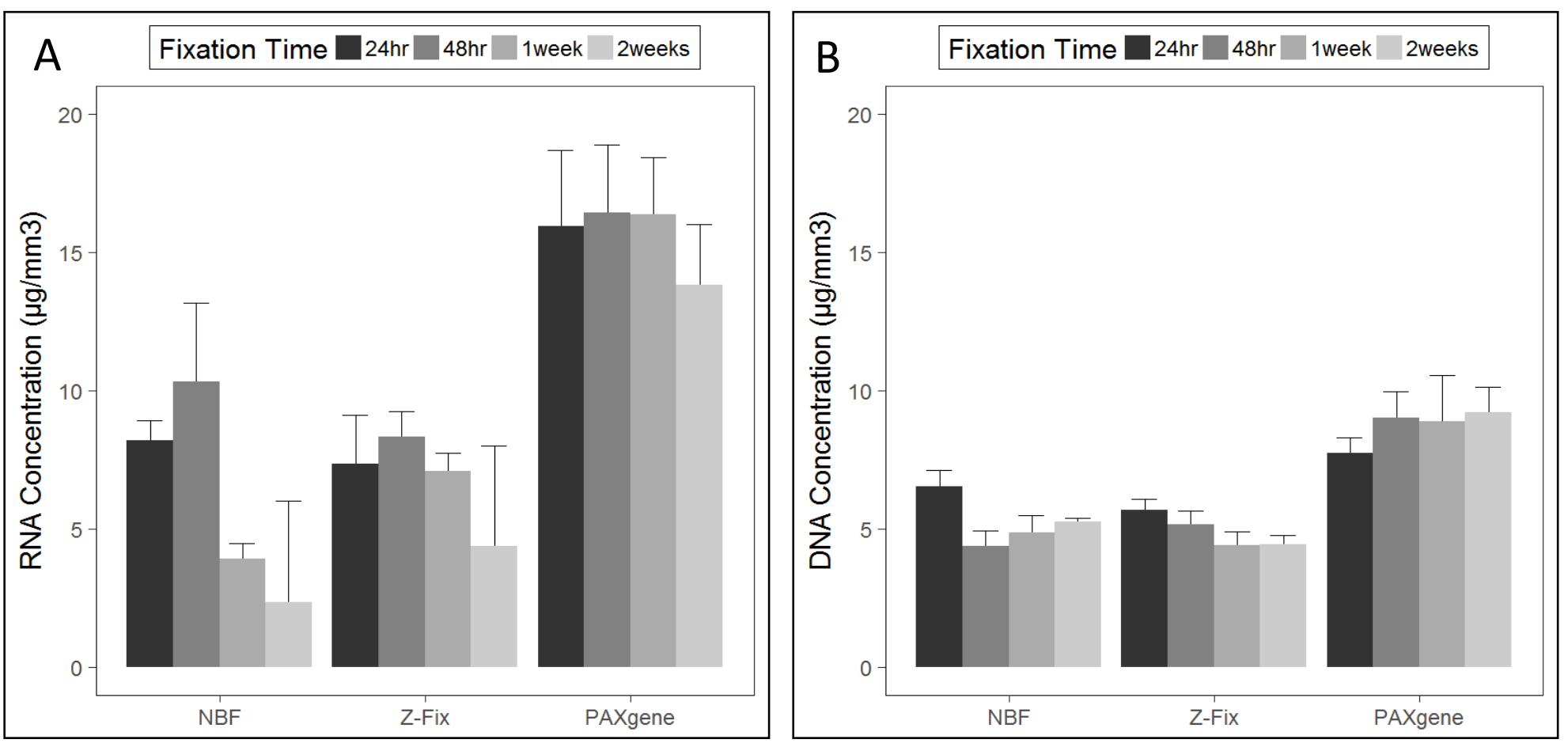
Figure 3. A) Mean RIN scores of extracted RNA and B) fragment size (bp) of extracted DNA from FFPE LCM samples of smallmouth bass liver fixed for $24 \mathrm{hr}, 48 \mathrm{hr}$, one week, and two weeks in 10\% neutral buffered formalin (NBF), Z-Fix, and PAXgene fixatives. Error bars represent the standard error of the mean.
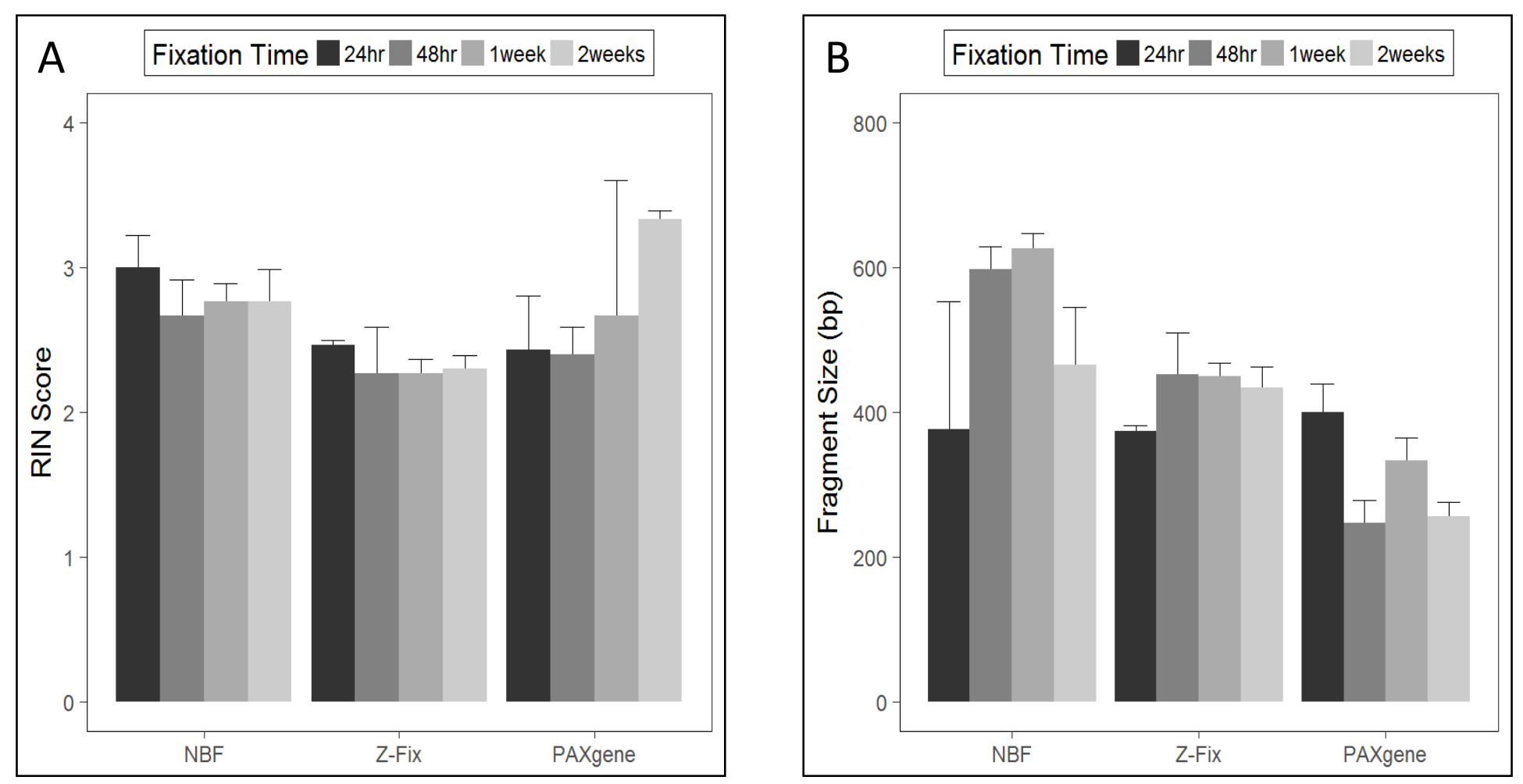
Figure 4. Results of the qPCR assay targeting the elongation factor 1 alpha gene with Z-Fix and $10 \%$ neutral buffered formalin samples fixed for $48 \mathrm{hr}$. Samples from both fixatives had average CT values within close range of each other and they fell within range of the four highest standards.

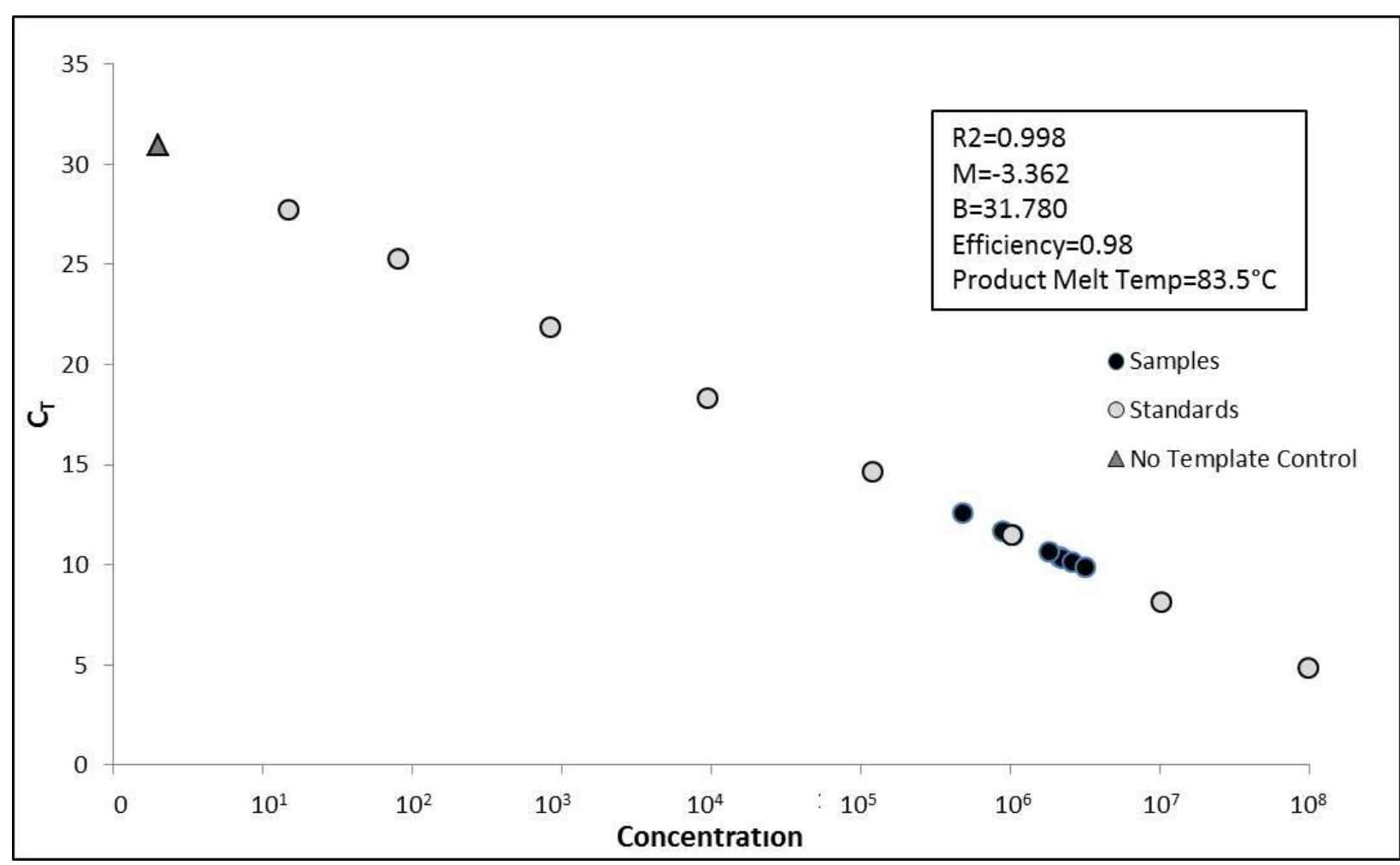


Figure 5. 10-fold serial dilution of DNA extracted from smallmouth bass liver. The dynamic range per reaction is shown with observed values overlapping the expected values.

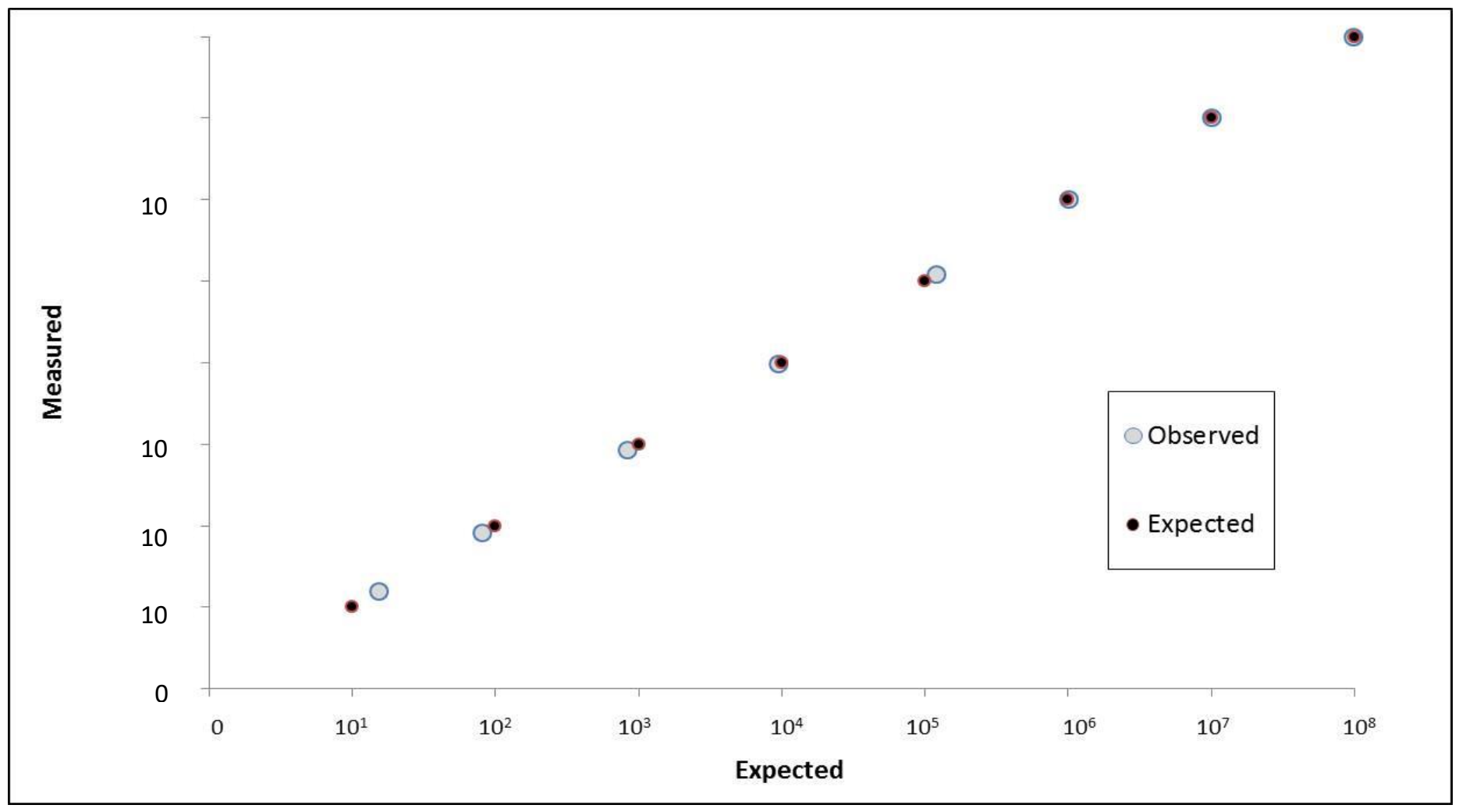




\section{Tables}

Table 1. Mean RNA and DNA concentration, RIN scores, and average fragment size ( \pm standard error of the mean) extracted from the livers of three smallmouth bass preserved in $10 \%$ neutral buffered formalin (NBF), Z-Fix ${ }^{\circledR}$, and PAXgene® for 24 hr, 48 hr, 1 week, or 2 weeks.

\begin{tabular}{|c|c|c|c|c|c|}
\hline $\begin{array}{c}\text { Fixative } \\
\text { Type }\end{array}$ & Fixation Time & $\begin{array}{c}\text { RNA } \\
\text { Concentration } \\
\left(\mu \mathrm{g} / \mathrm{mm}^{3}\right)\end{array}$ & $\begin{array}{c}\text { RNA RIN } \\
\text { Score }\end{array}$ & $\begin{array}{c}\text { DNA } \\
\text { Concentration } \\
\left(\mu \mathrm{g} / \mathrm{mm}^{3}\right)\end{array}$ & $\begin{array}{c}\text { Average } \\
\text { Fragment Size } \\
(\mathrm{bp})\end{array}$ \\
\hline \multirow{4}{*}{ NBF } & $24 \mathrm{hr}$ & $8.21 \pm 2.85$ & $3.00 \pm 0.25$ & $6.53 \pm 0.54$ & $376.76 \pm 31.11$ \\
\cline { 2 - 6 } & $48 \mathrm{hr}$ & $10.33 \pm 3.66$ & $2.67 \pm 0.22$ & $4.40 \pm 0.14$ & $597.67 \pm 79.51$ \\
\cline { 2 - 6 } & 1 week & $3.95 \pm 0.70$ & $2.77 \pm 0.22$ & $4.87 \pm 0.59$ & $625.33 \pm 175.82$ \\
\cline { 2 - 6 } & 2 weeks & $2.36 \pm 0.53$ & $2.77 \pm 0.12$ & $5.27 \pm 0.67$ & $465.00 \pm 21.28$ \\
\hline \multirow{4}{*}{ Z-Fix } & $24 \mathrm{hr}$ & $7.36 \pm 0.91$ & $2.47 \pm 0.32$ & $5.69 \pm 0.48$ & $373.33 \pm 58.22$ \\
\cline { 2 - 6 } & $48 \mathrm{hr}$ & $8.33 \pm 3.62$ & $2.27 \pm 0.09$ & $5.18 \pm 0.35$ & $451.67 \pm 27.84$ \\
\cline { 2 - 6 } & $1 \mathrm{week}$ & $7.10 \pm 1.77$ & $2.27 \pm 0.03$ & $4.42 \pm 0.10$ & $450.33 \pm 8.29$ \\
\hline \multirow{4}{*}{ PaxGene } & 2 weeks & $4.39 \pm 0.64$ & $2.30 \pm 0.10$ & $3.02 \pm 0.13$ & $434.67 \pm 18.12$ \\
\cline { 2 - 6 } & $24 \mathrm{hr}$ & $15.94 \pm 2.46$ & $2.43 \pm 0.19$ & $7.18 \pm 0.66$ & $400.67 \pm 31.38$ \\
\cline { 2 - 6 } & $48 \mathrm{hr}$ & $16.42 \pm 2.18$ & $2.40 \pm 0.06$ & $9.15 \pm 1.24$ & $247.00 \pm 19.35$ \\
\cline { 2 - 6 } & $1 \mathrm{week}$ & $16.35 \pm 2.74$ & $2.67 \pm 0.37$ & $9.08 \pm 0.69$ & $333.00 \pm 38.56$ \\
\hline
\end{tabular}


Table 2. The mean (range) and median of transcripts quantified with the Nanostring nCounter® with LCM samples of liver preserved in Z-Fix (ZF) and 10\% neutral buffered formalin (NBF). *Denotes a transcript that only had one sample above the limit of detection therefore it was not included (NA).

\begin{tabular}{|c|cc|cc|}
\hline & \multicolumn{1}{|c|}{$\mathrm{NBF}(\mathrm{n}=3)$} & $\underline{\text { Z-FIX (n=3) }}$ & \\
Gene Name & Mean (Range) & Median & Mean (Range) & Median \\
\hline 17B Hydroxysteroid Dehydrogenase & $79(61-96)$ & 79 & $82(45-108)$ & 92 \\
40S ribosomal protein S12 & $2262(763-3181)$ & 2843 & $1709(1344-2110)$ & 1674 \\
Androgen Receptor alpha & BD & BD & BD & BD \\
Androgen Receptor beta & $147(132-162)$ & 147 & $114(81-134)$ & 126 \\
Apolipoprotein A1 & $132490(19296-220468)$ & 157706 & $124341(85048-149072)$ & 138904 \\
Aryl Hydrocarbon Receptor & $\mathrm{BD}$ & $\mathrm{BD}$ & $\mathrm{BD}$ & $\mathrm{BD}$ \\
BCL-2 & $\mathrm{BD}$ & $\mathrm{BD}$ & $\mathrm{BD}$ & $\mathrm{BD}$ \\
C-reactive protein-like & $\mathrm{BD}$ & $\mathrm{BD}$ & $\mathrm{BD}$ & $\mathrm{BD}$ \\
C3 & $36256(9835-49732)$ & 49200 & $36607(26336-45946)$ & 37540 \\
CYP1A & $155(49-220)$ & 197 & $176(100-300)$ & 127 \\
CYP3A & $452(75-780)$ & 500 & $403(285-463)$ & 461 \\
Catalase & $893(274-1392)$ & 1014 & $1094(574-1701)$ & 1007 \\
Choriogenin & $124(83-164)$ & 124 & $128(73-167)$ & 144 \\
Elongation Factor 1A & $8620(2499-11889)$ & 11472 & $9660(6674-12895)$ & 9410 \\
Epidermal Growth Factor Receptor & $\mathrm{BD}$ & $\mathrm{BD}$ & $\mathrm{BD}$ & $\mathrm{BD}$ \\
Epoxide Hydrolase 1 & $147(130-163)$ & 147 & $112(94-136)$ & 105 \\
Estrogen Receptor A & $\mathrm{BD}$ & $\mathrm{BD}$ & $\mathrm{BD}$ & $\mathrm{BD}$ \\
Estrogen Receptor B1 & $66(53-78)$ & 66 & $56(39-74)$ & 54 \\
Estrogen Receptor B2 & $97(73-121)$ & 97 & $82(57-97)$ & 91 \\
3D & & & & \\
Gukaryotic Translation Initiation Factor & $526(62-842)$ & 673 & $546(381-775)$ & 481 \\
GST A-like & $52(44-60)$ & 52 & $38(31-45)$ & 38 \\
IL1b & $90(75-105)$ & 90 & $76(51-92)$ & 84 \\
Glucokinase & $\mathrm{BD}$ & $\mathrm{BD}$ & $\mathrm{BD}$ & $\mathrm{BD}$ \\
Glutathione Peroxidase 1 & $92(85-98)$ & 92 & $51(42-63)$ & 48 \\
Glutathione Reductase & $51(36-65)$ & 51 & $34(31-36)$ & 33.5 \\
Glutathione S-Transferase theta-1 & $1613(462-2523)$ & 1854 & $1541(950-2133)$ & 1541 \\
Heat Shock Proteins 71 & $4202(995-7006)$ & 4605 & $4185(2148-5864)$ & 4544 \\
Heat Shock Proteins 90B & $1780(413-3042)$ & 1886 & $1956(1119-2830)$ & 1918 \\
Hepcidin 1 & $50(41-59)$ & 50 & $35(34-36)$ & 35 \\
Hepcidin 2 & $\mathrm{BD}$ & $\mathrm{BD}$ & $\mathrm{BD}$ & $\mathrm{BD}$ \\
Hypoxanthine Phosphoribosyltransferase & & & $65(53-73)$ & 69 \\
Insulin-like Growth Factor 1 & $176(34-297)$ & 197 & $180(111-247)$ & 182
\end{tabular}




\begin{tabular}{|c|c|c|c|c|}
\hline LMBV MCP & BD & $\mathrm{BD}$ & BD & BD \\
\hline Metallothionein & $247(220-274)$ & 247 & $167(124-203)$ & 173 \\
\hline Proliferating Cell Nuclear Antigen & $61(40-82)$ & 61 & $41(37-46)$ & 39 \\
\hline Ribosomal Protein L8 & $1348(462-2021)$ & 1561 & $1092(783-1317)$ & 1176 \\
\hline Serum amyloid A-5 & BD & $\mathrm{BD}$ & $\mathrm{BD}$ & BD \\
\hline Serum amyloid $\mathrm{P}$ & $\mathrm{BD}$ & BD & $\mathrm{BD}$ & $\mathrm{BD}$ \\
\hline Superoxide Dismutase & $131(35-183)$ & 175 & $138(103-199)$ & 113 \\
\hline Tata Box Binding Protein & $\mathrm{BD}$ & $\mathrm{BD}$ & $\mathrm{BD}$ & $\mathrm{BD}$ \\
\hline Thyroid Hormone Receptor beta & $\mathrm{NA}^{*}$ & NA* & $66(33-86)$ & 80 \\
\hline Transferrin & $27928(9715-44076)$ & 29994 & $27581(14511-38775)$ & 29457 \\
\hline Transforming Growth Factor B & $\mathrm{BD}$ & BD & BD & BD \\
\hline Type I Deiodinase & $1234(189-2083)$ & 1430 & $1154(822-1364)$ & 1275 \\
\hline Type II Deiodinase & $\mathrm{BD}$ & $\mathrm{BD}$ & $\mathrm{BD}$ & $\mathrm{BD}$ \\
\hline Vitellogenin & $\mathrm{BD}$ & $\mathrm{BD}$ & $\mathrm{BD}$ & $\mathrm{BD}$ \\
\hline $\begin{array}{l}\text { Warm Temperature Acclimation Protein } \\
\qquad 65\end{array}$ & $122(115-129)$ & 122 & $111(86-157)$ & 91 \\
\hline Zona Pellucida 3 & $\mathrm{BD}$ & $\mathrm{BD}$ & $\mathrm{BD}$ & $\mathrm{BD}$ \\
\hline Haptoglobin & $\mathrm{BD}$ & $\mathrm{BD}$ & $\mathrm{BD}$ & $\mathrm{BD}$ \\
\hline
\end{tabular}




\title{
Chapter Six: Testes Transcriptome Development and Alterations in Transcript Abundance in Intersex Smallmouth Bass (Micropterus dolomieu)
}

\begin{abstract}
Smallmouth bass are a sensitive indicator species of exposure to estrogenic endocrine disruptors, responding with induction of testicular oocytes (TO) and vitellogenin. However, the mechanisms of induction of TO and associated risk factors are not fully understood. As a nonmodel species, genomic and transcriptomic information for smallmouth bass is limited. In this study, a partial testes transcriptome was developed using RNAseq and pooled samples of testes with and without TO. Transcript sequences with differential expression were selected and used to develop a custom CodeSet for the Nanostring nCounter®. Testicular tissue from 174 wild smallmouth bass was analyzed using NanoStringDiff to identify differential transcript abundance in smallmouth bass with and without TO. A Spearman's Rank Correlation analysis was used to identify transcripts correlated with TO severity. A total of 40 transcripts were quantified with the nCounter® technology. The results of the transcript abundance analysis revealed 14 differentially regulated transcripts in testes with TO, including 11 upregulated transcripts associated with oocyte development and three downregulated transcripts associated with male spermatogenesis and steroidogenesis. Additionally, 30 transcripts were correlated with TO severity. Identification of molecular changes associated with TO in smallmouth bass provides a better understanding of the mechanisms of action involved in intersex induction. The suite of molecular markers can be used to identify changes occurring at key developmental periods and throughout the reproductive cycle. Together with plasma analyses, hepatic transcript abundance
\end{abstract}


and histopathology, these markers will aid in the evaluation of specific contaminant exposures and detection of risk factors associated with TO induction in smallmouth bass.

\section{Introduction}

Intersex, as evidenced by the presence of testicular oocytes (TO), has been used worldwide as an indicator of exposure to estrogenic chemicals (Bahamonde et al. 2013; Hinck et al. 2009; Jobling et al. 1998). The presence of TO is associated with exposure to wastewater treatment plant effluent (Jobling et al. 2006; Norris et al. 2018; Tetreault et al. 2011), agricultural runoff (Abdel-moneim et al. 2017; Blazer et al. 2012; Blazer et al. 2014) and industrial (pulp and kraft mill) effluents (Fentress et al. 2006) in numerous fish species. Intersex was first described in male smallmouth bass from the Potomac River basin in 2003 (Blazer et al. 2007) and from the Susquehanna River basin in 2007 (Blazet et al. 2014). It has become a concern of the public and management agencies as these rivers are a drinking water supply for millions of people and smallmouth bass are an important recreational sportfish. Reproductive effects such as reduced sperm motility and abundance have been observed in smallmouth bass (Blazer et al. 2012), although population-level effects are currently unknown. While studies of wild smallmouth bass have found correlations of TO prevalence and severity with agricultural land use (Abdel-moneim et al. 2015; Blazer et al. 2012; Blazer et al. 2014) and individual chemicals such as estrone (Blazer et al. 2014) and herbicides (Blazer et al. 2012), important risk factors that could be addressed through management actions are not yet fully understood.

Molecular identification of transcripts associated with intersex has been reported in numerous species, generally model species, exposed to individual contaminants (Depiereux et al. 2014; Feswick et al. 2016; Kobayashi et al. 2017). The use of Next-Generation Sequencing 
(NGS), particularly RNA-Sequencing (RNA-Seq), on non-model fish for transcriptome development and molecular marker discovery is highly valuable since existing sequence data are scarce. Unlike the abundance of sequencing data available for model species, such as zebrafish Danio rerio (Howe et al. 2013), fathead minnow Pimephales promelas (Burns et al. 2016), and medaka Oryzias latipes (Takeda 2008), there are limited data available for smallmouth bass. Currently, sequence data exists from smallmouth bass liver (Hahn et al. 2016) and the gonad of a closely related species, largemouth bass Micropterus salmoides (Garcia-Reyero et al. 2008).

In this study, testicular tissue was collected during ongoing fish health assessment studies within the Potomac and Susquehanna River drainages (tributaries of the Chesapeake Bay) and from the Ohio River drainage during the spring. The objectives were to 1) create a partial testes transcriptome with NGS, 2) identify differentially expressed transcripts between 16 individual intersex and non-intersex smallmouth bass with NGS, 3) identify candidate transcripts with NGS results that will be used for the creation of a Nanostring nCounter® CodeSet for a subset of transcripts to be analyzed with a large sample size, and 4) analyze associations between transcript abundance and TO presence/severity to better understand the mechanisms contributing to induction of intersex in an economically important sportfish.

\section{Methods}

\section{Fish Sampling}

In 2015-2017, testicular tissue was collected from adult (>250mm in length), male smallmouth bass at sites in the Potomac, Susquehanna and Lake Erie drainages during ongoing fish health studies (Figure 1). 
Collections occurred in the spring (prespawn) by boat electroshocking. In addition to the wild smallmouth bass, hatchery-reared males and immature females were obtained from Schultz's Fish Hatchery in Lake Ariel, Pennsylvania and held for approximately six months prior to sampling in well-water fed tanks at $20^{\circ} \mathrm{C}$ at the Leetown Science Center, Kearneysville, West Virginia. All fish were humanely euthanized with a lethal dose $(300 \mathrm{mg} / \mathrm{L})$ of tricaine methanesulfonate (MS-222, Argent Finquel, Redmond, Washington). During necropsies, the testes were excised and weighed to the nearest $0.01 \mathrm{~g}$, and one gonad was placed into bottles containing 10\% Z-Fix ${ }^{\mathrm{TM}}$ (Anatech Ltd, Battle Creek, Michigan) for histology and small sections of the second gonad placed into RNAlater ${ }^{\circledR}$ (ThermoFisher, Waltham, Massachusetts) tubes for RNA preservation. The gonadosomatic index (GSI) was calculated as follows: (gonad weight / body weight) $\times 100$. A Kruskal-Wallis one-way ANOVA was performed to determine if GSI was significantly different between fish with and without TO.

\section{Histological Analyses}

Tissues were allowed to fix for at least $24 \mathrm{hr}$ and routinely processed for histology, embedded in paraffin, sectioned at $5 \mu \mathrm{m}$, and stained with hematoxylin and eosin (Luna 1992). Five to eight cross-sections along the length of one testis were examined for the presence of testicular oocytes and a severity rating was assigned according to Blazer et al. (2007). A severity score of 1 indicated a single oocyte per field, 2 was multifocal groups of more than one oocyte per field not closely associated, 3 was clustered groups of 2-5 oocytes closely associated, and 4 was zonal groups of more than five closely associated oocytes. 


\section{Transcriptome Assembly}

Total RNA was extracted from 10-25 mg of tissue with an E.Z.N.A.® Total RNA Kit (Omega Bio-Tek, Norcross, Georgia) following manufacturer's protocols and stored at $-80^{\circ} \mathrm{C}$ until use. All samples were quantified with a Qubit 3 Fluorometer with a RNA HS Assay Kit (Agilent, Santa Clara, California). Total RNA from fourteen males without TO, ten males with TO, and fifteen immature females were pooled to create three samples which were used as template for RNA-seq libraries. Prior to pooling these samples, each individual sample was normalized to the sample with the lowest concentration of RNA. After pooling, samples were analyzed on an Agilent Bioanalyzer with an Agilent RNA 6000 Nano Kit (Agilent, Santa Clara, California). Three strand-specific, 150bp, paired-end libraries with poly(A) selection were constructed at the Institute for Genome Sciences in Baltimore, Maryland and sequenced on an Illumina HiSeq 4000 (Illumina, Inc., San Diego, California). The reads from these libraries were used for the de novo transcriptome assembly.

RNA-Seq was also conducted to identify transcript abundance differences in individual fish. Eight males with TO and eight males without TO were compared. Samples of the eight males with intersex were from the South and North Fork Shenandoah River and the South Branch Potomac River (Virginia and West Virginia). Samples of the eight non-intersex males were from Twenty Mile Creek, Bald Eagle Creek, and Wyalusing Creek (Pennsylvania). Libraries of $100 \mathrm{bp}$ single end sequences with poly(A) selection were constructed at the Huck Institutes of the Life Sciences at Penn State (State College, Pennsylvania) on an Illumina HiSeq 2500.

For both groups of samples, sequences were trimmed of adapters by the core laboratory and analyzed for quality with FastQC (Andrews 2010). For sequences used in transcriptome 
assembly, further trimming was done with Trimmomatic (Bolger et al. 2014) to improve sequence quality. The assembly program Trinity was used to create a de novo transcriptome assembly (Haas et al. 2013). Raw reads were mapped back to the assembly with Bowtie2 (Langmead and Salzberg 2012) to analyze assembly quality. The CD-HIT program (Limin et al. 2012; Weizhong and Godzik 2006) was used with the CD-HIT-EST package to cluster similar transcripts. Next, overlap and redundancy and multiple small isoforms were collapsed into one long isoform and sequences that did not contain an open reading frame were removed with EvidentialGene (Gilbert 2013). Assembly statistics were analyzed with Transrate (Smith-Unna et al. 2016). Finally, transcripts were annotated in Diamond (Butchfink et al. 2015) with a database consisting of four fish species: zebrafish, barramundi Lates calcarifer, medaka, and rainbow trout Oncorhynchus mykiss. The sensitive mode was chosen in Diamond to accommodate longer sequences.

\section{CodeSet Development and Transcript Abundance Analysis}

To determine differentially expressed genes between the eight individual males with and without TO, the program Blast2Go Pro (Götz et al. 2008) was used to produce a count table and perform a differential transcript abundance analysis (Robinson et al. 2010). Transcripts were significantly different with a false discovery rate $(\mathrm{FDR})<0.05$. The assembled transcriptome was used as the reference.

From these results, reproductive transcripts that were significantly associated with intersex were chosen to be included in the CodeSet for the Nanostring nCounter®. Additional reproductive transcripts were also included based on the literature and if they were used as biomarkers of intersex in other fish species (Bahamonde et al. 2015; Baron et al. 2005b; Deloffre 
et al. 2012; Depiereux et al. 2014; Garacia-Reyero et al. 2009; Kishi et al. 2006; Zhao and Hu 2012). Sequences were analyzed in Geneious (Kearse et al. 2012) to identify coding regions and annotation was confirmed with NCBI Blastx (Altschul et al. 1990; Table 1). The Nanostring nCounter® analysis was carried out at the USGS National Fish Health Research Laboratory according to manufacturer's protocol with $50 \mathrm{ng}$ of purified RNA. The Nanostring nCounter ${ }^{\circledR}$ has the capability to read up to 800 mRNA targets in one sample and provides expression data similar to real-time qPCR (Kulkarni (2011). With no amplification steps, the count data produced by the nCounter® is robust and allows for more transcripts and samples to be analyzed at a more cost effective rate than with qPCR.

Five housekeeping genes, including 40S ribosomal protein S18 (RPS18), beta actin (ACTB), eukaryotic translation initiation factor (EIF3D), 40S ribosomal protein S12 (RPS12), and ribosomal protein L8 (RPL8) were analyzed with NormFinder software (Andersen et al. 2004) to determine the three best housekeeping genes. The Bioconductor package NanoStringDiff (Wang et al. 2016) was used to analyze transcript abundance differences between fish with and without TO sampled between 2015-2017. NanoStringDiff was specifically created to fit the count data produced by the Nanostring nCounter ${ }^{\circledR}$ and incorporates normalization factors into the framework. Normalization factors were determined with positive controls (spike-in oligos), negative controls, and housekeeping genes. The limit of detection was determined as the mean of the negative controls plus two $\times$ the standard deviation.

Correlations of intersex severity and transcript abundance were examined with a Spearman's rank correlation analysis in R (R Core Team 2017). Significant correlations had a $P$ value $<0.05$ 


\section{Results}

\section{Transcriptome Assembly}

A total of $108,544,928,94,265,096$, and $92,702,334150 \mathrm{bp}$ reads were obtained with RNA-Seq for pooled samples of immature females, intersex males, and non-intersex males, respectively. The first 10 and last 15 bases were trimmed from all reads based on the FastQC results. After elimination of similar transcripts with CD-HIT and removal of redundant isoforms with EvidentialGene, the Trinity assembly produced a total of 50,892 transcripts with an average length of 1,360 bp and a range of 201-19,290 bp. The number of transcripts with an open reading frame (orf) was 20,027 , the $n 50$ was $2,591 \mathrm{bp}$, and the GC content was $46 \%$. The results of mapping the raw reads back to the assembly with Bowtie 2 produced a $96.5 \%$ overall alignment rate.

\section{Transcript Abundance Analysis}

Transcript abundance analysis conducted with edgeR compared eight males with TO and eight males without TO. A total of 839 transcripts were significantly differentially expressed with 242 transcripts upregulated and 597 downregulated in fish with TO (Figure 2; Table 1). Differentially expressed reproductive transcripts were selected to be included in the Nanostring nCounter® custom CodeSet. Similar to qPCR, the Nanostring nCounter® was used as a confirmatory tool for the results obtained with RNA-seq. Additionally, it allowed for quantification of a larger sample size of smallmouth bass at a more time and cost-efficient rate than with qPCR. In addition to differentially expressed reproductive genes with NGS, intersex 
and endocrine disruption-associated indicator genes identified in other fish species were also included in the CodeSet (Table 2).

\section{Wild Fish Metrics}

Testicular transcripts in 174 male smallmouth bass, sampled from multiple sites in the spring of 2015-2017, were compared. The mean body weight was $672.86 \mathrm{~g}$ with a range from 127.00-1864.00 $\mathrm{g}$ (Table 3). The mean testes weight was $4.84 \mathrm{~g}$ with a range from $0.29-27.30 \mathrm{~g}$. The mean gonadosomatic index (GSI) was 0.71 with a range from $0.14-2.00$. GSI was not significantly different between fish with and without TO. The overall prevalence of intersex males was $82 \%(n=143)$ with a mean severity of 1.11 and range from $0.2-3.0$ (mean severity does not include fish without TO). The transcript abundance of many of the 40 genes measured in wild smallmouth bass with TO (Table 4) and without (Table 5) varied greatly ranging from below detection (counts less than 30 ) to greater than 34,000 counts.

Differential expression analysis with NanoStringDiff identified 14 transcripts that were significantly differentially regulated in fish with TO (Figure 3). Eleven transcripts were significantly upregulated in intersex males including vitellogenin (vtg; FDR < 0.001), zona pellucida 3 (zp3; FDR $<0.001)$, uncharacterized protein 1 (up1; FDR $<0.001)$, vitellogenin C (vtg-c; FDR < 0.001), zona pellucida 3iX1 (zp3ixl; FDR 0.001), P43 5S RNA-binding protein (42sp43; FDR 0.003), homeobox protein NOBOX (nobox; FDR 0.003), insulin-like growth factor binding protein $3(i g f b p-3 ; \mathrm{FDR}=0.010)$, Wnt family member 5B $(w n t 5 b ; \mathrm{FDR}=0.010)$, zygote arrest protein $1($ zarl; FDR $=0.010)$, and follistatin $3(f s t 3 ; \mathrm{FDR}=0.041)$. Three transcripts were significantly downregulated in intersex males including 3 beta-hydroxysteroid 
dehydrogenase (3 $\beta$-HSD; FDR 0.001), insulin-like growth factor binding protein 5 (ifgbp-5; FDR 0.003 .

Intersex severity correlations identified a total of 30 genes significantly correlated with severity, although associations were weak (Table 6). Twenty genes were positively correlated and 10 genes were negatively correlated with intersex severity. Additionally, 12 of the same genes that were found to be associated with TO were also identified as significantly correlated with TO severity. Of these genes, all except $i g f b p-5$, were significantly upregulated in fish with TO and positively correlated to severity. Although not significant, igfbp-5 was downregulated in fish with TO and negatively associated with severity.

Transcripts of $v t g$ and $v t g-c$ were found in testes of smallmouth bass with and without TO. In fish with TO, 63\% had both $v t g$ and $v t g-c$ transcripts above the detection limit. In fish without TO, $32 \%$ had $v \operatorname{tg}$ and $35 \%$ had $v \operatorname{tg}-c$ transcripts above the detection limit.

\section{Discussion}

A partial testes transcriptome was developed using hatchery-reared and wild smallmouth bass, with and without TO (as assessed by histology), from multiple sites to identify transcripts associated with intersex. The overall prevalence of male smallmouth bass with TO was $82 \%$ and is consistent with smallmouth bass sampled in other regions of the United States (Abdel-moneim et al. 2017; Iwanowicz et al. 2016; Kadlec et al. 2017). Although there was a high prevalence of fish with TO, mean intersex severity was low (1.11), similar to previous findings (Blazer et al. 2012; Blazer et al. 2014). Transcripts were identified from a de novo transcriptome assembly of smallmouth bass testes and immature female ovary. The addition of immature ovary provided transcripts associated with primary oocytes, the stage observed in intersex smallmouth bass. 
Transcriptomic and literary information was used to create a Nanostring custom CodeSet consisting of 40 transcripts for use on the nCounter® system. To our knowledge, this is the first time testicular transcripts have been identified in smallmouth bass with NGS and quantified with the Nanostring nCounter® technology.

No unique transcripts were found in bass testes with or without TO. Unlike laboratory studies exposing fish to individual chemicals and assessing molecular changes, the fish in this study were exposed to varying complex mixtures of chemicals and environmental factors that may influence gonadal development during both sexual differentiation and recrudescence over multiple reproductive cycles. A previous study by Abdel-moneim et al. (2017) on smallmouth bass from the St. Joseph River in Indiana utilized qPCR of seven candidate transcripts in hepatic and testicular tissue. These included vtg, ers1, esr $\beta$, star, foxl2, lhr , and fshr, and similar to the current study, were identified in both individuals with and without TO. Transcript abundance analysis revealed only hepatic $v t g$ to be associated with intersex, but only when fish were sampled in the spring (Abdel-moneim et al. 2017). In the current study a correlation was found with testicular $v t g$ and TO.

The presence of TO in smallmouth bass is identified by histology, which has some limitations. For example, the gonads of some individual fish were large with testes weight ranging from 0.29 to $27.30 \mathrm{gm}$. While 5-8 cross-sections along the gonad are examined for testicular oocytes it is possible testes with a low severity and number of oocytes may be misdiagnosed as normal. This could explain the finding of some female-related transcripts in testes lacking TO. Conversely it is possible that germ cells not yet developed into observable oocytes have the associated gene expression. Further studies, perhaps using laser microdissection, will be necessary to better understand these changes. 
Transcript abundance analysis of Nanostring nCounter® data revealed a total of fourteen transcripts that were differentially regulated in fish with $\mathrm{TO}$ which in most cases were also significantly and positively associated with intersex severity. Transcripts associated with intersex have been identified in numerous fish, including rainbow darter Etheostoma caeruleum (Bahamonde et al. 2015), rainbow trout Oncorhynchus mykiss (Depiereux et al. 2014), fathead minnow Pimephales promelas (Feswick et al. 2016; Garcia-Reyero et al. 2009), medaka Oryzias latipes (Hirakawa et al. 2012; Zhao and Hu 2012), Mozambique tilapia Oreochromis mossambicus (Deloffre et al. 2012) and thicklip gray mullet Chelon labrosus (Diaz de Cerio et al. 2012). Similar to other fish species, oogenesis-related transcripts were upregulated and spermatogenesis-related transcripts were downregulated in smallmouth bass with TO. Of the upregulated transcripts, zona pellucida ( $z p$ ) (Hirakawa et al. 2012; Zhao and Hu 2012) and gonadal vtg (Depiereux et al. 2014) have also been found to be associated with intersex in other fishes. These transcripts are associated with egg development (Arukwe 2003; Bobe et al. 2008; Suzumori et al. 2002) and are highly expressed in female fish (Baron et al. 2005b; Diaz de Cerio et al. 2012; Zhao and Hu et al. 2012). Additionally, several types of 5S rRNA are known to accumulate in previtellogenic oocytes (Mazabraud et al. 1975) and have been suggested to be an oocyte marker in fish (Diaz de Cerio et al. 2012). Transcript abundance of the P43 5S RNAbinding protein gene $42 \operatorname{sp} 43$ was high in ovaries, very low in testes and intermediate in intersex male mullet suggesting it may be a good marker of TO (Diaz de Cerio et al. 2012). A similar gene, $42 s p 50$, was upregulated in male medaka exposed to $17 \alpha$-ethinylestradiol (Hirakawa et al. 2012).

Other transcripts associated with intersex in smallmouth bass included vtg-c, upl, nobox, $i g f b p 3$, wnt5b, zarl, and $f s t 3$. An up-regulation of $i g f b p-3$ and a downregulation of $i g f b p-5$ were 
noted in smallmouth bass with TO. Insulin-like growth factor-binding proteins modulate the availability and hence inhibit or potentiate the activity of insulin-like growth factors. In fish, igf3 is primarily expressed in adult gonads. Insulin-like growth factor binding proteins are known to play a role in oocyte maturation; however, igfbp-3 has also been found in preovulatory ovaries. Upregulation of $i g f b p-3$ but not $i g f b p-5$ by exposure to estrogen was observed in rainbow trout ovaries (Kamangar et al. 2006). In male zebrafish, igf-3 promotes the proliferation and differentiation of type A undifferentiated spermatogonia. In a study by Safian et al. (2016), an increase in $i g f b p-3$ lead to a decrease in type A undifferentiated spermatogonia, the primary cells involved in spermatogenesis (De Paiva Camargo et al. 2017). Further research indicated that $i g f b p-3$ and $i g f b p-5$ have opposing effects on controlling igf-3 bioactivity in zebrafish (Safian et al. 2016). Further work will need to be done to tease out the impact an upregulation of igfbp-3 may have on feminization in male smallmouth bass.

Transcripts that were downregulated, in addition to igfbp-5, were $3 \beta$ - $h s d$ and inhbb which are associated with sex steroid biosynthesis (Maugars and Schmitz 2008) and early development (Garcia de la Serrana and Macqueen 2018). A study of the walking catfish Clarias batrachus revealed that $3 \beta$-hsd plays an important role in gonadal development (Bhat et al. 2018) and was reduced in male rainbow trout exposed to 17 $\alpha$-ethinyl-estradiol (Baron et al. 2005a). It should be noted that a decrease in inhbb, which is produced in the sertoli cells of males (Pierik et al. 1998) was observed. In humans, inhbb has been found to be positively correlated with sperm abundance (Luisi et al. 2005) and is used as a biomarker of fertility in men (Pierik et al. 1998). A study by Blazer et al. (2012) revealed that intersex fish had reduced sperm abundance. Future studies on smallmouth bass would need to include sperm counts in order to determine if this association exists and whether it poses a fertility risk. 
A noteworthy finding was the detection of $v t g$ and $v t g-c$ in the testes of smallmouth bass. Vitellogenin (VTG), an egg yolk precursor protein, is normally transcribed in the liver and travels via blood to the gonad (Hara et al. 2016). Many studies have also identified extrahepatic VTG (protein) and vtg (transcripts) in multiple tissues, including the testis (Del Giudice et al. 2011; Shyu et al. 1986; Verderame et al. 2016). Future studies will aim to identify which cells transcribe $v t g$ and whether VTG is synthesized. Vitellogenin has also been recognized to play a role in immune function against microbes (Zhang et al. 2015), but it is yet to be determined if it has similar properties in smallmouth bass.

The findings in this study identify transcripts that are associated with TO in smallmouth bass. Additionally, the development of a partial testes transcriptome provides novel sequence data on transcripts from a non-model species of fish. Many transcripts associated with oocytes were upregulated in intersex smallmouth bass and transcripts associated with male reproductive function, such as spermatogenesis and steroidogenesis, were downregulated. The findings of this study provide biomarkers that can be evaluated in future work to determine the association of individual chemicals with differential regulation of these transcripts. Additionally, laboratory exposures to chemicals detected in the Susquehanna and Potomac River drainages will need to be conducted to validate the utility of these transcripts as molecular markers of intersex. Identification of contaminants associated with TO, exposure during key developmental periods (sexual differentiation, recrudescence), and the interaction of these genes provides valuable information to better understand the mechanisms responsible for TO induction in smallmouth bass.

\section{References}


Abdel-moneim A, Coulter DP, Mahapatra CT, Sepúlveda. Intersex in fishes and amphibians: population implications, prevalence, mechanisms and molecular biomarkers. J. Appl. Toxicol. 2015; doi:10.1002/jat.3204.

Abdel-moneim A, Deegan D, Gao J, De Perre C, Doucette JS, Jenkinson B, et al. Gonadal intersex in smallmouth bass Micropterus dolomieu from northern Indiana with correlations to molecular biomarkers and anthropogenic chemicals. Environ. Pollut. 2017;230:1099-107.

Altschul SF, Gish W, Miller W, Myers EW, Lipman DJ. Basic local alignment search tool. J. Mol. Biol. 1990;215:403-410.

Andrews S. FastQC: a quality control tool for high throughput sequence data. 2010. http://www.bioinformatics.babraham.ac.uk/projects/fastqc. Accessed 7 August 2017.

Arukwe A, Goksøyr A. Eggshell and egg yolk proteins in fish: hepatic proteins for the next generation: oogenetic, population, and evolutionary implications of endocrine disruption. Comp. Hepatol. 2003;2: http://www.comparative-hepatology.com/content/2/1/4.

Bahamonde PA, McMaster ME, Servos MR, Martyniuk CJ, Munkittrick KR. Molecular pathways associated with the intersex condition in rainbow darter (Etheostoma caeruleum) following exposures to municipal wastewater in the Grand River basin, ON, Canada. Part B. Aquat. Toxicol. 2015;159:302-16.

Bahamonde PA, Munkittrick KR, Martyniuk CJ. Intersex in teleost fish: are we distinguishing endocrine disruption from natural phenomena? Gen. Comp. Endocrinol. 2013;192:25-35.

Baron D, Fostier A, Breton B, Guiguen Y. Androgen and estrogen treatments alter steady state messengers RNA (mRNA) levels of testicular steroidogenic enzymes in the rainbow trout , Oncorhynchus mykiss. Mol. Reprod. Dev. 2005a;71:471-9.

Baron D, Houlgatte R, Fostier A, Guiguen Y. Large-scale temporal gene expression profiling during gonadal differentiation and early gametogenesis in rainbow trout. Biol. Reprod. 2005b;73:959-966.

Bhat IA, Rather MA, Nazi MI, Pathakota G-B, Goswami M, Sundaray JK, et al. Cloning, characterization, docking and expression analysis of 3-beta-hydroxysteroid dehydrogenase during ontogenetic development and annual reproductive cycles in catfish, Clarias batrachus. Theriogenology 2018;105:34-44.

Blazer VS, Iwanowicz LR, Henderson H, Mazik PM, Jenkins JA, Alvarez DA, et al. Reproductive endocrine disruption in smallmouth bass (Micropterus dolomieu) in the Potomac River basin: spatial and temporal comparisons of biological effects. Environ. Monit. Assess. 2012;184:4309-34. 
Blazer VS, Iwanowicz DD, Walsh HL, Sperry AJ, Iwanowicz LR, Alzarez DA, et al. Reproductive health indicators of fishes from Pennsylvania watersheds: association with chemicals of emerging concern. Environ. Monit. Assess. 2014;186:6471-91.

Blazer VS, Iwanowicz LR, Iwanowicz DD, Smith DR, Young JA, Hedrick JD, et al. Intersex (testicular oocytes) in smallmouth bass from the Potomac River and selected nearby drainage. J. Aquat. Anim. Health 2007;19:242-53.

Bobe J, Nguyen T, Mahé S, Monget P. In silico identification and molecular characterization of genes predominantly expressed in the fish oocyte. BMC Genomics 2008;9: doi:10.1186/1471-2164-9-499.

Bolger AM, Lohse M, Usadel B. Trimmomatic: a flexible trimmer for Illumina sequence data. Bioinformatics 2014;30:2114-20.

Burns FR, Cogburn LA, Ankley GT, Villeneuve DL, Waits E, Chang Y-J, et al. Sequencing and de novo draft assemblies of a fathead minnow (Pimephales promelas) reference genome. Environ. Toxicol. Chem. 2016;35:212-7.

Butchfink B, Xie C, Huson D. Fast and sensitive protein alignment using DIAMOND. Nature Methods 2015;12:59-60.

De Paiva Camargo M, Cassel M, de Jesus LWO, Nóbrega RH,Borella MI. Characterization of undifferentiated spermatogonia and the spermatogonial niche in the lambari fish Astyanax altiparanae. Theriogenology 2017;96:97-102.

Del Giudice G, Prisco M, Agnese M, Verderame M, Limatola E, Andreuccetti P. Expression of vitellogenein in the testis and kidney of the spotted ray Torpedo marmorata exposed to 17ß-estradiol. Gen. Comp. Endocrinol. 2011;174:318-25.

Deloffre LAM, Andrade A, Filipe AI, Canario AVM. Reference genes to quantify gene expression during oogenesis in a teleost fish. Gene 2012;506:69-75.

Depiereux S, Liagre M, Danis L, De Meulder B, Depiereux E, Segner H, et al. Intersex occurrence in rainbow trout (Oncorhynchus mykiss) male fry chronically exposed to ethynylestradiol. PLoS ONE 2014;9: e98531. doi:10.1371/journal.pone.0098531.

Diaz de Cerio O, Rojo-Bartolomé I, Bizarro C, Ortiz-Zarragoitia M, Cancio I. 5S rRNA and accompanying proteins in gonads: powerful markers to identify sex and reproductive endocrine disruption in fish. Env. Sci. Technol. 2012;46:7763-71.

Fentress JA, Steele SL, Bart Jr. HL, Cheek AO. Reproductive disruption in wild longear sunfish (Lepomis megalotis) exposed to kraft mill effluent. Environ. Health Perspect. 2006;114:40-5. 
Feswick A, Loughery JR, Isaacs MA, Munkittrick KR, Martyniuk CJ. Molecular initiating events of the intersex phenotype: low-dose exposure to $17 \alpha$-ethinylestradiol rapidly regulates molecular networks associated with gonad differentiation in the adult fathead minnow testis. Aquat. Toxicol. 2016;181:46-56.

Garcia de la Serrana D, Macqueen DJ. Insulin-like growth factor-binding proteins of teleost fishes. Front. Endocrinol 2018;9: doi: 10.3389/fendo.2018.00080.

Garcia-Reyero N, Griffitt RJ, Liu L, Kroll KJ, Farmerie WG, Barber DS, et al. Construction of a robust microarray from a non-model species (largemouth bass) using pyrosequencing technology. J. Fish Biol. 2008;72:2354-76.

Garcia-Reyero N, Kroll KJ, Liu L, Orlando EF, Watanabe KH, Sepúlveda MS, et al. Gene expression responses in male fathead minnows exposed to binary mixtures of and estrogen and antiestrogen. BMC Genomics 2009;10: doi:10.1186/1471-2164-10-308.

Gilbert D. EvidentialGene: tr2aacds, mRNA transcript assembly software. 2013. http://arthropods.eugenes.org/EvidentialGene/trassembly.html. Accessed 29 May 2017.

Götz S, García-Gómez JM, Terol J, Williams TD, Nagaraj SH, Nueda MJ, et al. Highthroughput functional annotation and data mining with Blast2Go suite. Nucleic Acids Res. 2008;36:3420-35.

Haas BJ, Papanicolaou A, Yassour M, Grabherr M, Blood PD, Bowden J, et al. De novo transcript sequence reconstruction from RNA-seq using the Trinity platform for reference generation and analysis. Nat. Protoc. 2013;8:1494-512.

Hahn CM, Iwanowicz LR, Cornman RS, Mazik PM, Blazer VS. Transcriptome discovery in non-model wild fish species for the development of quantitative transcript abundance assays. Comp. Biochem. Physiol. Part D 2016;20:27-40.

Hara A, Hiramatsu N, Fujita T. Vitellogenesis and choriogenesis in fishes. Fish Sci. 2016;82:187-202.

Hinck JE, Blazer VS, Schmitt CJ, Papoulias DM, Tillitt DE. Widespread occurrence of intersex in black basses (Micropterus spp.) from U.S. river, 1995-2004. Aquat. Toxicol. 2009;95:60-70.

Hirakawa I, Miyagawa S, Katsu Y, Kagami Y, Tatarazako N, Kobayashi T, et al. Gene expression profiles in the testis associated with testis-ova in adult Japanese medaka (Oryzias latipes) exposed to 17 $\alpha$-ethinylestradiol. Chemosphere 2012;87:668-674.

Howe K, Clark MD, Torroja CF, Torrance J, Berthelot C, Muffato M, et al. The zebrafish reference genome sequence and its relationship to the human genome. Nature 2013;496:498-503. 
Iwanowicz LR, Blazer VS, Pinkney AE, Guy CP, Major AM, Munney K, et al. Evidence of estrogenic endocrine disruption in smallmouth and largemouth bass inhabiting Northeast U.S. national wildlife refuge waters: a reconnaissance study. Ecotoxicol. Environ. Saf. 2016;124:50-59.

Jobling S, Nolan M, Tyler CR, Brighty G, Sumpter JP. Widespread sexual disruption in wild fish. Environ. Sci. Technol. 1998;32:2498-506.

Jobling S, Williams R, Johnson A, Taylor A, Gross-Sorokin M, Nolan M, et al. Predicted exposures to steroid estrogens in U.K. rivers correlate with widespread sexual disruption in wild fish populations. Environ. Health Perspect. 2006;114:32-9.

Kadlec SM, Johnson RD, Mount DR, Olker JH, Borkholder BD, Schoff PK. Testicular oocytes in smallmouth bass in northeastern Minnesota in relation to varying levels of human activity. Environ. Toxicol. Chem. 2017;36:3424-35.

Kamangar BB, Gabillard J-C, Bobe J. Insulin-like growth factor-binding protein (IGFBP) -1, $2,-3,-4,-5$, and -6 and IGFBP-related protein 1 during rainbow trout postvitellogenesis and oocyte maturation: molecular characterization, expression profiles, and hormonal regulation. Endocinology 2006;147:2399-2410.

Kearse M, Moir R, Wilson A, Stones-Havas S, Cheung M, Sturrock S, et al. Geneious Basic: an integrated and extendable desktop software platform for the organization and analysis of sequence data. Bioinformatics 2012;28:1647-9.

Kishi K, Kitagawa E, Onikura N, Nakamura A, Iwahashi H. Expression analysis of sex-specific and $17 \beta$-estradiol-responsive genes in the Japanese medaka, Oryzias latipes, using oligonucleotide microarrays. Genomics 2006;88:241-251.

Kobayashi T, Chiba A, Sato T, Myosho T, Yamamoto J, Okamura T, et al. Estrogen alters gonadal soma-derived factor (Gsdf)/Foxl2 expression levels in the testes associated with testis-ova differentiation in adult medaka, Oryzias latipes. Aquat. Toxicol. 2017;191:209-18.

Kulkarni MM. Digital multiplexed gene expression analysis using the NanoString nCounter system. Curr. Protoc. Mol. Biol. 2011;25B: doi: 10.1002/0471142727.mb25b10s94.

Langmead B, Salzberg S. Fast gapped-read alignment with Bowtie 2. Nature Methods. 2012;9:357-359.

Limin F, Beifang N, Zhengwei Z, Sitao W, Weizhong L. CD-HIT: accelerated for clustering the Next-Generation Sequencing data. Bioinformatics 2012;28:3150-2.

Luisi S, Florio P, Reis FM, Petraglia F. Inhibins in female and male reproductive physiology: role in gametogenesis, conception, implantation and early pregnancy. Hum. Reprod. Update 2005; 11:123-35. 
Luna L. Histopathologic methods and color atlas of special stains and tissue artifacts. American Histolabs, Inc., Gaithersburg, Maryland; 1992.

Maugars G, Schmitz M. Gene expression profiling during spermatogenesis in early maturing male Atlantic salmon parr testes. Gen. Comp. Endocrinol. 2008;159:178-87.

Mazabraud A, Wegnez M, Denis H. Biochemical research on oogenesis. RNA accumulation in the oocytes of teleosts. Dev. Bio. 1975;44:326-322.

Norris DO, Bolden AL, Vajda AM. The occurrence of intersex fishes in Boulder Creek, Colorado, is a recent phenomenon. Gen. Comp. Endocrinol. 2018;265:56-60.

Pierik FH, Vreeburg JTM, Stijnen T, de Jong FH, Weber RFA. Serum inhibin B as a marker of spermatogenesis. J. Clin. Endocrinol. Metab. 1998;83:3110-4.

R Core Team. R: A language and environment for statistical computing. 2017. https://www.Rproject.org/. Accessed 5 May 2017.

Robinson MD, McCarthy DJ, Smyth GK. edgeR: a Bioconductor package for differential expression analysis of digital gene expression data. Bioinformatics 2010;26:139-40.

Safian D, Morais RDVS, Bogerd J, Schulz RW. Igf binding proteins protect undifferentiated spermatogonia in the zebrafish testis against excessive differentiation. Endocrinology 2016;157:4423-33.

Shyu A-B, Raff RA, Blumenthal T. Expression of the vitellogenin gene in female and male sea urchin. Proc. Natl. Acad. Sci. USA 1986;83:3865-9.

Smith-Unna RD, Boursnell C, Patro R, Hibberd JM, Kelly S. Transrate: reference free quality assessment of de-novo transcriptome assemblies. Genome Research 2016;doi: http://dx.doi.org/10.1101/gr.196469.115.

Suzumori N, Yan C, Matzuk MM, Rajkovic A. Nobox is a homeobox-encoding gene preferentially expressed in primordial and growing oocytes. Mech. Dev. 2002;111:137141.

Takeda H. Draft genome of the medaka fish: a comprehensive resource for medaka developmental genetics and vertebrate evolutionary biology. Develop. Growth Differ. 2008;50:S157-66.

Tetreault GR, Bennett CJ, Shires K, Knight B, Servos MR, McMaster ME. Intesex and reproductive impairment of wild fish exposed to multiple municipal wastewater discharges. Aquat. Toxicol. 2011;104:278-90. 
Verderame M, Limatola E, Scudiero R. Ectopic synthesis of vitellogenin in testis and epididymis of estrogen-treated lizard Podarcis sicula. Gen. Comp. Endocrinol. 2016;235:57-63.

Wang H, Horbinski C, Wu H, Liu Y, Sheng S, Liu J, et al. NanoStringDiff: a novel statistical method for differential expression analysis based on NanoString nCounter data. Nucleic Acids Res. 2016;44:e151 doi:10.1093/nar/gkw677.

Weizhong L, Godzik A. Cd-hit: a fast program for clustering and comparing large sets of protein or nucleotide sequences. Bioinformatics, (2006) 22:1658-9.

Zhang S, Dong Y, Cui P. Vitellogenin is an immunocompetent molecule for mother and offspring in fish. Fish Shellfish Immunol. 2015;46:710-5.

Zhao Y, Hu J. Development of a molecular biomarker for detecting intersex after exposure of male medaka fish to synthetic estrogen. Environ. Toxicol. Chem. 2012;31:1765-73. 


\section{Figures}

Figure 1. Map of sites where adult, male smallmouth bass were sampled in 2015-2017 from the Potomac and Susquehanna River drainages in Virginia, West Virginia, and Pennsylvania and the Presque Isle Bay drainage in northern Pennsylvania. Subset: Chesapeake Bay drainage (gray area).

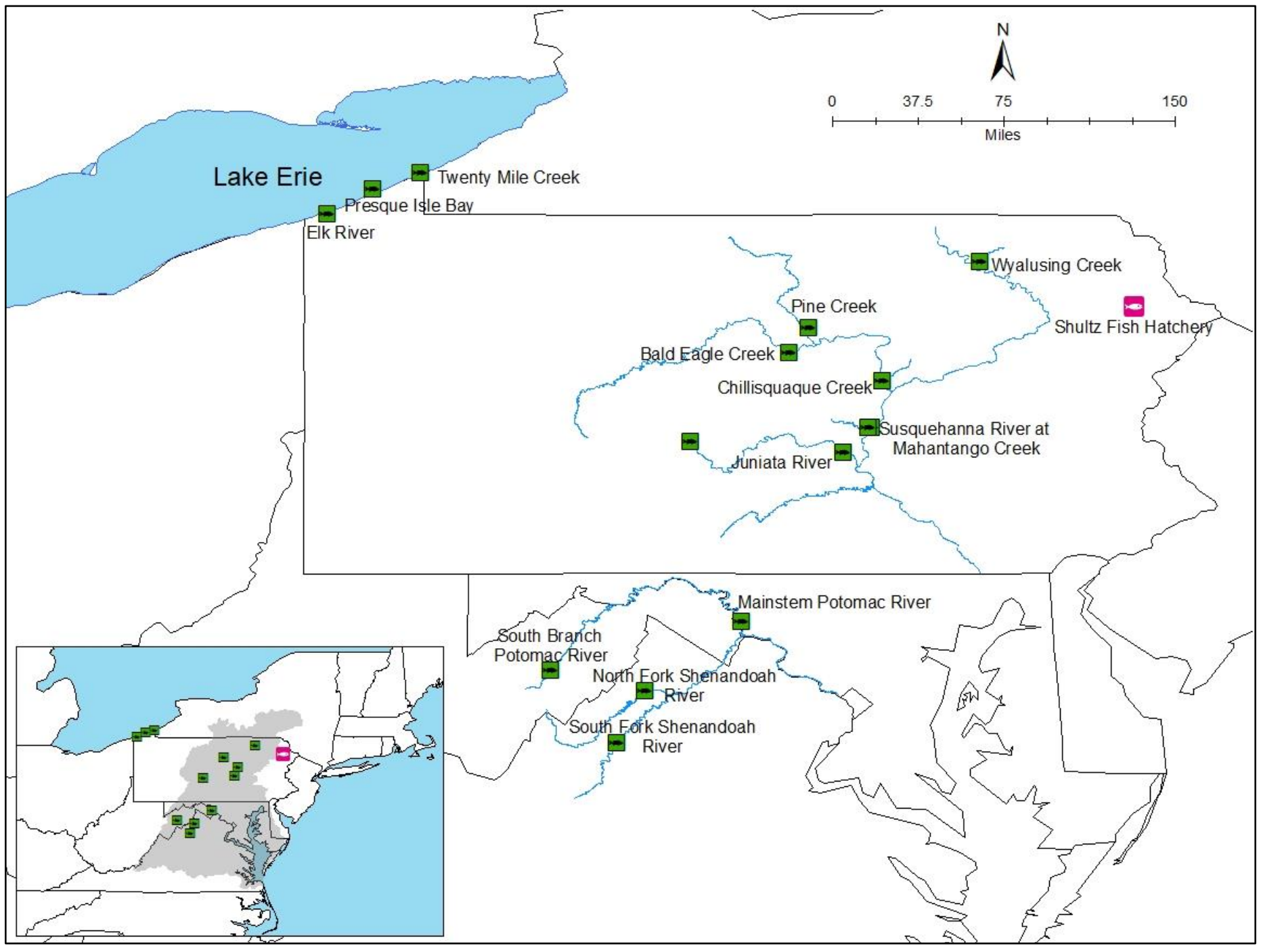


Figure 2. $\log 2$ count data of the top 50 differentially expressed transcripts from eight intersex and eight non-intersex smallmouth bass.

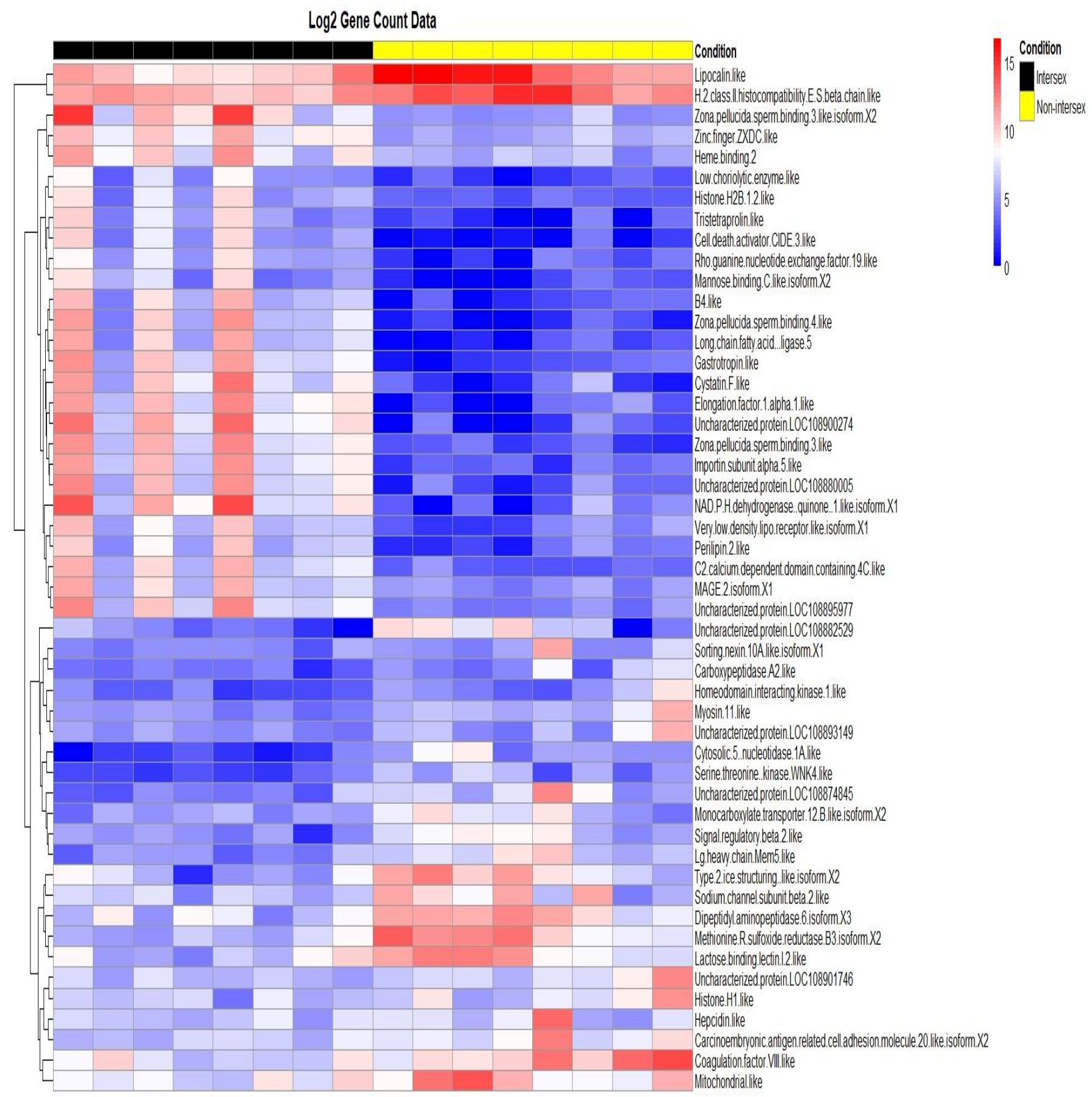


Figure 3. Differentially expressed transcripts in smallmouth bass with testicular oocytes. Log2 fold change of 14 transcripts differentially expressed in smallmouth bass with TO compared to bass without testicular oocytes.

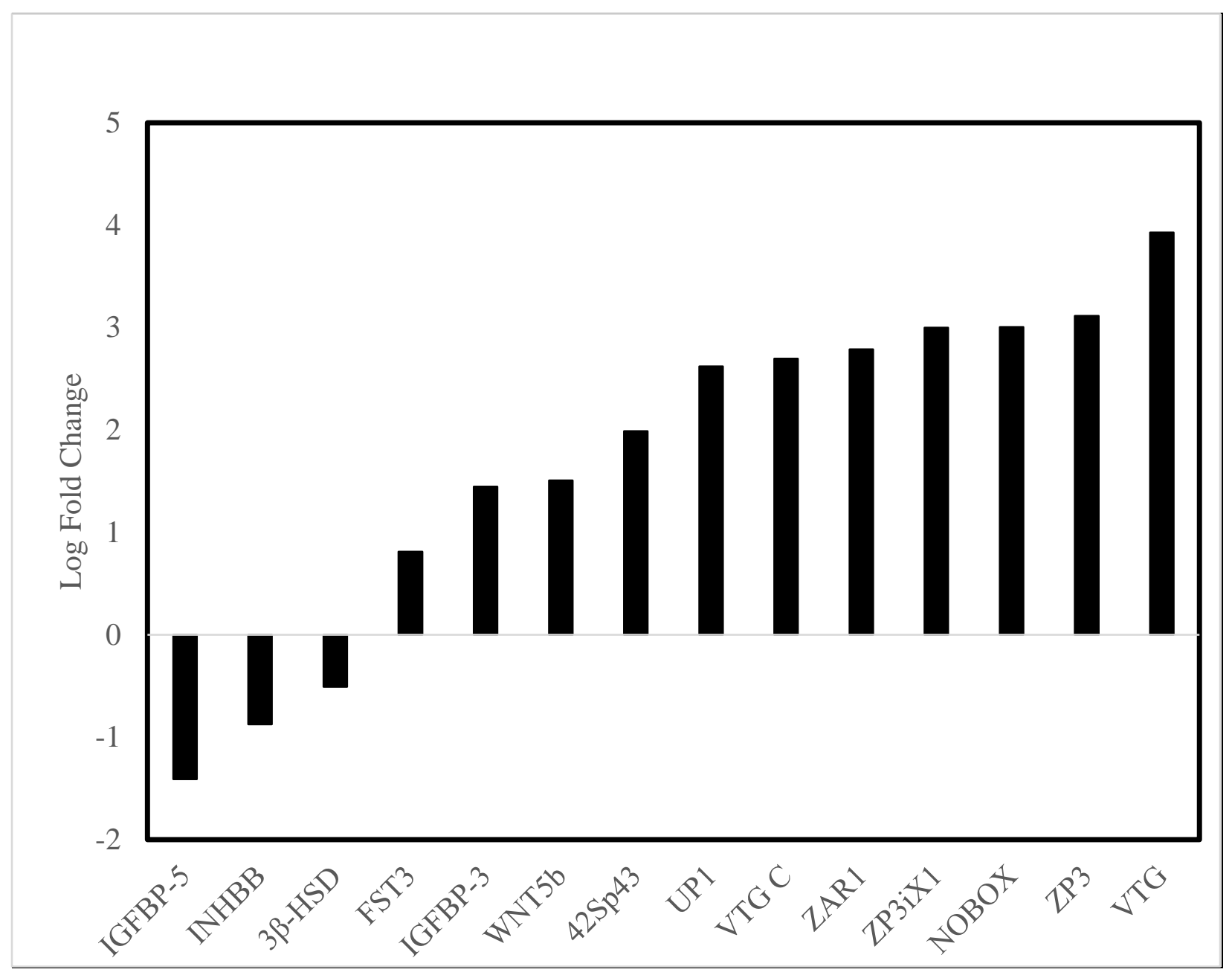




\section{Tables}

Table 1. The top 50 differentially expressed transcripts in intersex versus non-intersex smallmouth bass. Transcripts were significantly different with a FDR $<0.05$.

\begin{tabular}{cccc|}
\hline Gene Name & $\operatorname{logFC}$ & $\log$ FPM & FDR \\
\hline Methionine-R-sulfoxide reductase B3 isoform & -5.109 & 5.916 & $<0.001$ \\
Lipocalin-like & -4.551 & 9.613 & $<0.001$ \\
Uncharacterized protein LOC108874845 & -4.500 & 3.424 & 0.001 \\
Cytosolic 5 -nucleotidase 1A-like & -4.366 & 1.207 & $<0.001$ \\
Coagulation factor VIII-like & -4.080 & 6.504 & 0.001 \\
Sorting nexin-10A-like isoform & -3.737 & 2.554 & 0.007 \\
Type-2 ice-structuring -like isoform & -3.716 & 4.931 & 0.008 \\
Uncharacterized protein LOC108882529 & -3.716 & 2.508 & 0.016 \\
Hepcidin-like & -3.633 & 4.556 & 0.018 \\
Mitochondrial-like & -3.560 & 6.085 & 0.005 \\
Lactose-binding lectin 1-2-like & -3.475 & 5.584 & 0.011 \\
Myosin-11-like & -3.456 & 2.399 & 0.001 \\
Sodium channel subunit beta-2-like & -3.390 & 4.159 & 0.002 \\
Dipeptidyl aminopeptidase 6 isoform & -3.353 & 5.049 & 0.001 \\
Uncharacterized protein LOC108893149 & -3.315 & 2.452 & 0.006 \\
Carcinoembryonic antigen-related cell adhesion molecule 20-like isoform & -3.215 & 4.119 & 0.003 \\
Signal-regulatory beta-2-like & -3.144 & 2.129 & $<0.001$ \\
Uncharacterized protein LOC108901746 & -3.099 & 3.636 & 0.006 \\
Lg heavy chain Mem5-like & -3.065 & 2.376 & 0.001 \\
Homeodomain-interacting kinase 1-like & -3.062 & 0.921 & 0.009 \\
Monocarboxylate transporter 12-B-like isoform & -2.932 & 2.398 & 0.002
\end{tabular}


Carboxypeptidase A2-like

Histone H1-like

Serine threonine- kinase WNK4-like

$\mathrm{H}-2$ class II histocompatibility E-S beta chain-like

Zinc finger ZXDC-like

Low choriolytic enzyme-like

Heme-binding 2

Histone H2B 1 2-like

Rho guanine nucleotide exchange factor 19-like

Very low-density lipo receptor-like isoform

MAGE 2 isoform

Perilipin-2-like

Mannose-binding C-like isoform

Tristetraprolin-like

C2 calcium-dependent domain-containing 4C-like

Uncharacterized protein LOC108895977

$$
\text { B4-like }
$$

Cell death activator CIDE-3-like

$$
\text { Cystatin-F-like }
$$

Elongation factor 1-alpha 1-like

Importin subunit alpha-5-like

Uncharacterized protein LOC108880005

Long-chain-fatty-acid-- ligase 5

Gastrotropin-like

Zona pellucida sperm-binding 3-like

Zona pellucida sperm-binding 3-like isoform

Zona pellucida sperm-binding 4-like

\begin{tabular}{|c|c|c|}
\hline-2.879 & 0.821 & 0.004 \\
\hline-2.845 & 3.665 & 0.015 \\
\hline-2.827 & 0.174 & 0.001 \\
\hline-2.826 & 8.249 & $<0.001$ \\
\hline 3.743 & 3.837 & $<0.001$ \\
\hline 3.890 & 1.132 & 0.001 \\
\hline 3.963 & 4.245 & $<0.001$ \\
\hline 4.150 & 1.867 & $<0.001$ \\
\hline 4.240 & 1.561 & $<0.001$ \\
\hline 4.309 & 2.822 & $<0.001$ \\
\hline 4.371 & 3.495 & $<0.001$ \\
\hline 4.559 & 2.479 & $<0.001$ \\
\hline 5.077 & 1.759 & 0.001 \\
\hline 5.206 & 2.065 & 0.001 \\
\hline 5.339 & 3.302 & $<0.001$ \\
\hline 5.793 & 4.491 & $<0.001$ \\
\hline 5.943 & 3.082 & $<0.001$ \\
\hline 6.139 & 2.070 & $<0.001$ \\
\hline 6.379 & 4.545 & $<0.001$ \\
\hline 6.405 & 4.389 & $<0.001$ \\
\hline 6.435 & 4.191 & $<0.001$ \\
\hline 6.478 & 4.492 & $<0.001$ \\
\hline 6.779 & 3.463 & $<0.001$ \\
\hline 6.945 & 4.087 & $<0.001$ \\
\hline 7.202 & 4.523 & $<0.001$ \\
\hline 7.324 & 6.874 & $<0.001$ \\
\hline 7.462 & 3.928 & $<0.001$ \\
\hline 7.750 & 5.377 & $<0.001$ \\
\hline 7.904 & 6.248 & $<0.001$ \\
\hline
\end{tabular}

Uncharacterized protein LOC108900274 
Table 2. Transcripts included in the Nanostring nCounter® CodeSet.

\begin{tabular}{|c|c|c|c|}
\hline Gene & $\begin{array}{l}\text { Tm } \\
\mathbf{C P}\end{array}$ & $\begin{array}{l}\text { Tm } \\
\text { RP }\end{array}$ & Target Sequence \\
\hline $\begin{array}{l}\text { 17-B hydroxysteroid } \\
\text { dehydrogenase (17 beta-HSD) }\end{array}$ & 83 & 84 & $\begin{array}{l}\text { CATCCTCAACATCTCGTCTGCCAGTGGGATGTACCCTGTTCCTCTCCTCACT } \\
\text { GTCTACTCTGCCTCCAAGGCGTTTGTGGACTTCTTCTCCCGAGGACTG }\end{array}$ \\
\hline $\begin{array}{l}3 \text { beta-hydroxysteroid } \\
\text { dehydrogenase ( } 3 \text { beta-HSD) }\end{array}$ & 83 & 79 & $\begin{array}{l}\text { AACTTTTAACTAGAGTCTGGAGGACTGTAGAGGCGACACAAAGTTGAATG } \\
\text { TTTTCGAGGGCGACATCAGAGACGGTGATTTCCTGAGAAAACTTGTCGTG }\end{array}$ \\
\hline $\begin{array}{l}\text { 40S ribosomal protein } \mathrm{S} 18 \\
\qquad(40 \mathrm{SRPL} 18) *\end{array}$ & 86 & 86 & $\begin{array}{l}\text { GAGAGCTGACTGATGAGGAGGTTGAGCGTGTGGTGACCATCATGCAGAAT } \\
\text { CCTCGCCAGTACAAAATCCCAGACTGGTTCCTCAACAGGCAGAAGGACGT }\end{array}$ \\
\hline Beta-actin(ACTB) $*$ & 86 & 85 & $\begin{array}{l}\text { GTACGTTGCCATCCAGGCTGTGCTGTCCCTGTATGCCTCTGGTCGTACCAC } \\
\text { TGGTATCGTCATGGACTCCGGTGATGGTGTGACCCACACAGTGCCCATC }\end{array}$ \\
\hline Aromatase (CYP19A1A) & 85 & 85 & $\begin{array}{l}\text { GCTGGAGATGGTGATCGCAGCACCAGACACTCTGTCCATCAGCCTCTTCTT } \\
\text { CATGCTGCTGCTCCTCAAACAAAATCCAGATGTGGAGCTGAAGCTGCTA }\end{array}$ \\
\hline $\begin{array}{l}\text { Cytochrome P450 11B (CYP } \\
\text { P450 11B) }\end{array}$ & 86 & 86 & $\begin{array}{l}\text { GAAGCCAGCTGCCATGTGCTCTACGGGGAGCGTATTGGCCTCTTCTCCTCT } \\
\text { TCTCCCTCCTTGGAGTCGCAGAAGTTCATCTGGGCCGTGGAGCGGATGT }\end{array}$ \\
\hline $\begin{array}{c}\text { Dehydrogenase reductase } \\
\text { SDR family member } 11 \\
\text { (DHRS11) }\end{array}$ & 82 & 84 & $\begin{array}{l}\text { TTAGCCTTGTCTATCTGCACCCGTGAGGCATACAAATCAATGAAGGAAAG } \\
\text { GAATGTGGATGATGGCCACATAATCAATATTAACAGTATGGGTGGGCACC }\end{array}$ \\
\hline $\begin{array}{c}\text { Doublesex and mab-3 related } \\
\text { transcription factor } 1 \\
\text { (DMRT1) }\end{array}$ & 85 & 84 & $\begin{array}{l}\text { GCTGGAGCAGATTGCTTGTTCTCTGTGGAGGCACGATCTCCGACACCTACC } \\
\text { AGTACCTCCGCTCCTTCTCTTGTTGTTGCAGGGAGTCGCTCGGCGGCGT }\end{array}$ \\
\hline $\begin{array}{c}\text { Doublesex and mab-3 related } \\
\text { transcription factor } 2 \\
\text { (DMRT2) }\end{array}$ & 82 & 84 & $\begin{array}{l}\text { AGGACGATTTATCAGCGGCATATTCGACCGTCCACCATGCTCGCCAAAAG } \\
\text { CATCCTCGAAGGATACTGTCCGGTGCAGTCTGATCCATTCCTGGCGTCCA }\end{array}$ \\
\hline
\end{tabular}


Doublesex and mab-3 related transcription factor 3 (DMRT3)

Eukaryotic translation initiation factor 3D (EIF3D) *

Follistatin (FST)

Follistatin 3 (FST3)

Gonadotropin releasing hormone receptor (GnRHR)

Homeobox protein NOBOX (NOBOX)

Inhibin alpha (INHA)

Inhibin beta $b$ (INHBB)

Insulin like growth factor binding protein 1 (IGFBP-1)

Insulin like growth factor binding protein $2 \mathrm{~A}$ (IGFBP2A)

Insulin like growth factor binding protein 3 (IGFBP-3)
CAGCAGGCCAACGAGAGTCTGGAGAGCCTCATCCCGGAGTCACTCAGAGT GCTGCCCGGTATCGGTATATCCGGAGCCAGCGAGGGGAACCAGGGAGCCC

ACATGACTCAGTTCAACATGCAGACGCTACCTAAGAGCGCCAAGCAAAAG GAGAGGGATCGTATGCGCCTGCAGAAGAAGTTCCAAAAGCAGTTTGGTGT

AAATACTTCAAGTCGTATGACAATGGTGACTCTCAGCTGGACTCCTCAGAG CTGCTCAAATTCATCCAGCAAAATGACTCGGTTGTGGAGTTGCAGTCTT

GCATGGGACACCCGGACCTGGAGGTCATGTACCAAGGAGACTGTAAAAAG TCGTGCTCCAATGTGGTGTGCCCAGGTACCCACACCTGTGTGACGGACCA

CTGTAGCGTGGTGCATGAGTGTCGTGCTGTCAGTCCCTCAGATATTCCTTTT TCACAACGTAACCATCATTCATCCCAAGGACTTCACTCAGTGTACCAC

82 GTTAGAGCATTTAGAGGCCTTGTTCCAGGAGGACCACTATCCTGACGCAG AGAAGAGGAAAGTCATCGCTGCTTCAGTTGGTGTCACACCTCAAAGAATT

ATCTGCCCACTTCTGGTTCTATGCAGGCAAAGGAGCCACATCCAACTCCTC TGCCCAGCTGTTCATTCTCACTTCAGAGCAGAAGCTACTTCAGGCGGCA

TCATCAGCTTTGCGGAGAAAGATGATATGGTGACATCCAAGTCCAGCCTCT TCTTCCAGATCTCCAGTGAGGGGAACCAGAACCTGCATGTGACGCAGGC

CCCTGTCATGTTGAGCTACAGAGAGCCTTGGATAAGATTGCCAAATCCCAG CAGAAATTGGGAGACAAATTAACCAGATTCTACCTCCCTAACTGTGACA

ATGACCAAAAACCTCATGCCTATAACAATGCTGTCGTACGCGGGCGTCAG CTTGCTAATCCTCTCCGCGTCTCTCGCCGGTGCCTCCCTGGCCGAGATGG

ACCGGGGCAAACACAGGAGAACGCTGGTAATCGGTTAGAAGAGCCTTCTT CCAACGTGACAGCAACGATGACGGTGTTACCTGGTGTGGTGACTGTGAAG 
Insulin like growth factor binding protein 5 (IGFBP-5)

Luteinizing hormone receptor (LHR)

Nanos

Nuclear receptor subfamily 0 group B member 1 (NR0B1)

P43 5S RNA-binding protein (42Sp43)

Relaxin receptor 2 (RXFP2)

Sperm flagellar protein 1 (SPEF1)

Sperm flagellar protein 2 (SPEF2)

Sperm surface protein SP17 (SPA17)

SRY-box 7 (SOX7)

SRY-box 9b (SOX9b)

Steroidogenic acute regulatory protein (STAR)
TCTAATTCAAAGCATGAAGGACACTTCCAGGGTCTTGGCTCTCACTCTGCA CATTCCCAACTGTGACAAGAAGGGCTTCTTCAAGCGCAAACAGTGTAAG

CCTCATCACTGTCACCAACTCCAAGATTCTGCTGGTGCTCTTCTTCCCAATC AATTCCTGTGCCAATCCCTTCCTCTACGCTATCTTCACCAAGGCTTTC

ATCTGGCTACTAAATCTACGCTGCCAAACCCTTTGGCTCATCAGCGTCCAC CTGATGGTTTGCGGTACGCTTCAGATTCCCTAGGTGCTAATACACCAGA

GCATATCTGAAAGGAGCTGTGCTGTTCAACCCAGATGTGGAAGGTTTGCG CTGTCTTCACTACATCCAGTCTCTGCGTCGGGAGGCGCACCAGGCTTTAA

CAAAAAGCGCAGAATGTTTAAACTGCACTTACAGGAGCATGAAGTGGCTG CTAAATTCAAGTGTCTGAAGGACGGATGCGCTGCCACGTTCGACTCCCAT

TAAGAGCAGAGAACAACCTGCATGCTGCCTGCATCAAAGTCCTCTGTTGTG CAGACTGCCTCATGGGTGTGTACCTGTTTTTTGTTGGAGTGTTCGATGT

TTGGAGCACACTACAGAGAATATACTGGATTTGGAATACTACGACACCAG GGACCGAGAGAAACCTCATACGGAAATTTGTCAGACCGAAGCGAAACTTC

CACTATCTTGCAGAAATGAAGAGTATTGACCAACTATCAGAGGTGGTTCGT CACCACATAGAGGCTGGTGCTAAGTTGCAGAATCAGCTGTTATTGGAAT

GCAGCTAATGAAAAAGACAGCATCTCTGTTCCAGACCAAGATATACCTCA GTCTAAGTTAGAGCCCACAGACTTATTATCATACAGAGGGGTTTCAGGTA

GGGGGCACACATATAGGTCACATCCCTCACATGTCCCAAACTGGAAGTGG CGGTGGACTGATCCCTGGCCATCCGCTGTCTTACTACAGTACCTCATCTT

CTGGCCGATCAATACCCGCATCTGCACAACGCGGAACTCAGCAAAACCCT GGGCAAACTTTGGAGATTGCTCAACGAAGTAGAGAAGCGCCCGTTTGTGG

AGATGTTGCCTGACATTGGGAAGGTGTTCAAGCTGGAAGTGATGTTGGAG CAGCGTCCTGACAATCTTTACAAAGAGCTGGTGGGAAATATGGAGCAAAT 


\begin{tabular}{|c|c|c|c|}
\hline $\begin{array}{l}\text { Synaptonemal complex } \\
\text { protein } 1(\mathrm{SYCP} 1)\end{array}$ & 85 & 81 & $\begin{array}{l}\text { ACCTTTCAGACGGAGCAACTAAGGAAGGACATCACACAGCATGAAGTAAA } \\
\text { GTACAAAGAACTATTATCCAACTTTAACGAGCTCCAGTCTGAGAAGGCAG }\end{array}$ \\
\hline Uncharacterized protein 1 & 85 & 86 & $\begin{array}{l}\text { ATGAACCCAGCTACGCCTCCAGTGAGCAGATTACCAGCAGTACAGGCTCT } \\
\text { CTCCAAGCCTCTTGGAACAGCAGGAACTCTGCCCAGGGAGCTCGTAACCT }\end{array}$ \\
\hline Uncharacterized protein 2 & 82 & 81 & $\begin{array}{l}\text { CTGGACATCAACTACACACTGACTGTTCTGCCTGAAAACGAACTGTATTAC } \\
\text { CACCTGGCATCTATTGAGGCATTGTTCACAGATGTCTATCCTCCATCCT }\end{array}$ \\
\hline Vitellogenin (VTG) & 81 & 79 & $\begin{array}{l}\text { CTGCCAGGCCCATTATACAACGCAGAGTAGCTAAATTTGAGAAGAAGTTC } \\
\text { TGTGCTAAAGCTGTTGCCATTGGAGTTAGGGGTTGTTTCATGGTTACCAC }\end{array}$ \\
\hline Vitellogenin C (VTG C) & 85 & 84 & $\begin{array}{l}\text { TTCCAAGAAAGCCACCCAGCGAGTACGTGTGTCCTCTGATTCAGCCTCAAG } \\
\text { CGTCAGAGAGAGATCTAATCACAGCCATCATGACAATATAATGGAAAGC }\end{array}$ \\
\hline $\begin{array}{l}\text { Wnt family member 5B } \\
\text { (WNT5B) }\end{array}$ & 85 & 86 & $\begin{array}{l}\text { GGGCGGTTGCGGCGACAACGTACATTATGGCTACCGATTTGCCCGGGAGT } \\
\text { TTGTGGACGCCAGGGAGAGAGAGAAGAATTACCCGCGTGGTTCTGCTGAG }\end{array}$ \\
\hline Zona pellucida 3 (ZP3) & 81 & 79 & $\begin{array}{l}\text { TGGGAGTCATCTGTTGTACACCAATGATCTGACCTACATTTCCTCTCCCGA } \\
\text { TTCTAACATTCTCCCGTCCACTCACCTAGTTGTCTGTGAGTATGAGAGG }\end{array}$ \\
\hline Zona pellucida 3iX1 (ZP3iX1) & 82 & 83 & $\begin{array}{l}\text { CAAGAGTTATGCTGTGGATGGCATTTCCCTGCATCCCACCTGGGTTCCTTTT } \\
\text { GTCAAAACAGCCTCAGCAGAGGATCAGCTGGTCTTCAATTTGCGAACC }\end{array}$ \\
\hline Zona pellucida 4 (ZP4) & 84 & 83 & $\begin{array}{l}\text { CACAGCCAGCCACGGACTCCCACGACCATTTCCCTATCTCTGAGGTTTTGG } \\
\text { GACCTTTCAATAGCACAGTACAGAACTCTAGACCTGCAATGCCCGTATT }\end{array}$ \\
\hline Zona pellucida AX (ZPAX) & 81 & 84 & $\begin{array}{l}\text { GGTTACAGTCTACTCCCTCCCTCTGATCTTTGGGCTCATTATCCTACCTGAA } \\
\text { CAAATGCAGTTCACTCACTCAGTGGATTTGCAGGCGTCTCTGCAGGAT }\end{array}$ \\
\hline $\begin{array}{l}\text { Zygote arrest protein } 1 \\
\text { (ZAR1) }\end{array}$ & 80 & 84 & $\begin{array}{l}\text { GGGTCCAACTTTCAGTTCCTAGAGCAGAGGTATGGCTTTTTCCACTGCAAA } \\
\text { AAGTGTAACATCCGGTGGGAGAGTGCTTATGTGTGGTGCATCTCTGGAA }\end{array}$ \\
\hline
\end{tabular}


$100 \mathrm{bp}$ coding regions of sequences used in the Nanostring nCounter ${ }^{\circledR}$ CodeSet to detect genes associated with intersex in male smallmouth bass from the Susquehanna and Potomac River drainages and Presque Isle Bay drainage. Melting temperatures ( $\left.\mathrm{T}_{\mathrm{m}}\right)$ of capture probes $(\mathrm{CP})$ and reporter probes $(\mathrm{RP})$ are listed. Housekeeping genes are indicated with an asterisk $(*)$. 
Table 3. Site locations and metrics of male smallmouth bass sampled in the spring of 2015-2017.

\begin{tabular}{|c|c|c|c|c|c|c|c|c|}
\hline Sample & Drainage & $\begin{array}{c}\text { Years } \\
\text { Sampled }\end{array}$ & $\begin{array}{l}\# \text { of } \\
\text { Fish }\end{array}$ & $\begin{array}{c}\text { Intersex } \\
\text { Prevalence } \\
(\%)\end{array}$ & $\begin{array}{l}\text { Intesex } \\
\text { Severity }\end{array}$ & $\begin{array}{c}\text { Testes } \\
\text { Weight } \\
\text { (mg) }\end{array}$ & $\begin{array}{c}\text { Body Weight } \\
(\mathrm{g})\end{array}$ & GSI \\
\hline $\begin{array}{c}\text { Chilisquaque } \\
\text { Creek }\end{array}$ & Susquehanna & $\begin{array}{l}2015 \\
2017\end{array}$ & 17 & 94 & $0.80(0.55)$ & $2.99(3.22)$ & $\begin{array}{l}1044.59 \\
(247.06)\end{array}$ & $0.61(0.42)$ \\
\hline $\begin{array}{c}\text { Upper Juniata } \\
\text { River }\end{array}$ & Susquehanna & 2016 & 9 & 44 & $0.75(0.19)$ & $8.03(3.72)$ & $\begin{array}{c}769.78 \\
(319.63) \\
\end{array}$ & $1.04(0.26)$ \\
\hline Pine Creek & Susquehanna & 2015 & 17 & 71 & $0.37(0.19)$ & $5.41(2.53)$ & $\begin{array}{c}774.41 \\
(385.90)\end{array}$ & $0.75(0.30)$ \\
\hline Mahantango Creek & Susquehanna & 2015 & 10 & 30 & $0.67(0.31)$ & $5.56(2.07)$ & $\begin{array}{c}855.30 \\
(280.31) \\
\end{array}$ & $0.66(0.16)$ \\
\hline Wyalusing Creek & Susquehanna & 2015 & 10 & 60 & $0.37(0.20)$ & $1.85(0.71)$ & $\begin{array}{c}547.80 \\
(237.61)\end{array}$ & $0.36(0.13)$ \\
\hline Elk Creek & Lake Erie & 2016 & 5 & 100 & $1.44(0.33)$ & $8.97(5.00)$ & $\begin{array}{c}719.60 \\
(327.94)\end{array}$ & $1.19(0.22)$ \\
\hline Tionesta Lake & Lake Erie & 2016 & 8 & 75 & $1.20(0.36)$ & $3.70(2.40)$ & $\begin{array}{c}478.88 \\
(270.64)\end{array}$ & $0.73(0.20)$ \\
\hline Presque Isle Bay & Lake Erie & 2016 & 9 & 89 & $1.40(0.84)$ & $14.98(6.30)$ & $\begin{array}{l}1299.44 \\
(361.01) \\
\end{array}$ & $1.12(0.19)$ \\
\hline Twenty Mile Creek & Lake Erie & 2016 & 10 & 90 & $0.87(0.46)$ & $13.14(6.61)$ & $\begin{array}{l}1011.60 \\
(310.50) \\
\end{array}$ & $1.25(0.29)$ \\
\hline Antietam Creek & Potomac & $\begin{array}{l}2015 \\
2016\end{array}$ & 25 & 92 & $1.32(0.72)$ & $2.76(1.61)$ & $\begin{array}{c}437.36 \\
(141.44)\end{array}$ & $0.64(0.28)$ \\
\hline $\begin{array}{l}\text { South Branch } \\
\text { Potomac River }\end{array}$ & Potomac & $\begin{array}{l}2015, \\
2016, \\
2017\end{array}$ & 36 & 97 & $1.15(0.56)$ & $2.94(2.09)$ & $\begin{array}{c}456.83 \\
(290.14)\end{array}$ & $0.63(0.22)$ \\
\hline
\end{tabular}




\begin{tabular}{|ccccccccc|}
\hline $\begin{array}{c}\text { South Fork } \\
\text { Shenandoah River }\end{array}$ & Potomac & 2016 & 9 & 89 & $2.08(0.67)$ & $2.28(1.10)$ & $\begin{array}{c}575.33 \\
(234.21)\end{array}$ & $0.39(0.11)$ \\
\hline $\begin{array}{c}\text { North Fork } \\
\text { Shenandoah River }\end{array}$ & Potomac & 2016 & 9 & 100 & $1.71(0.81)$ & $1.81(1.81)$ & $\begin{array}{c}377.44 \\
(189.14)\end{array}$ & $0.47(0.19)$ \\
\hline
\end{tabular}

Data presented are the mean (stdev) of various metrics of male fish sampled from the Susquehanna and Potomac River drainages and Lake Erie drainage in the spring of 2015-2017. Male fish with a severity rating of 0 were excluded from calculating mean intersex severity. 
Table 4. Statistics of each of the 40 genes from smallmouth bass with testicular oocytes.

\begin{tabular}{|c|c|c|c|c|}
\hline Gene & Mean & Median & Min & Max \\
\hline 17-B Hydroxysteroid Dehydrogenase (HSD17B) & 1072 & 837 & 103 & 4561 \\
\hline 3 beta-hydroxysteroid dehydrogenase (HSD3B) & 2804 & 2119 & 179 & 11064 \\
\hline 40S ribosomal protein S18 (RPS18)* & 33270 & 14781 & 926 & 161666 \\
\hline P43 5S RNA-binding protein (42Sp43) & 143 & 51 & $\mathrm{BD}$ & 1903 \\
\hline B-actin $(\mathrm{ACTB}) *$ & 55339 & 48894 & 8284 & 161666 \\
\hline Cytochrome P450 11B (CYP11B) & 168 & 140 & BD & 833 \\
\hline Aromatase (CYP19A1A) & 149 & 51 & $\mathrm{BD}$ & 1509 \\
\hline Dehydrogenase reductase SDR family member 11 (DHRS11) & 3381 & 271 & $\mathrm{BD}$ & 24464 \\
\hline Doublesex and mab-3 related transcription factor 1 (DMRT1) & 4345 & 2863 & 58 & 16417 \\
\hline Doublesex and mab-3 related transcription factor 2 (DMRT2) & 328 & 239 & BD & 1137 \\
\hline Doublesex and mab-3 related transcription factor 3 (DMRT3) & 158 & 113 & BD & 1340 \\
\hline Eukaryotic translation initiation factor 3D (EIF3D)* & 2525 & 1495 & BD & 11303 \\
\hline Follistatin (FST) & 2010 & 1400 & $\mathrm{BD}$ & 8117 \\
\hline Follistatin 3 (FST3) & 712 & 496 & $\mathrm{BD}$ & 3767 \\
\hline Gonadotropin releasing hormone receptor (GnRHR) & 184 & 126 & $\mathrm{BD}$ & 801 \\
\hline Homeobox protein (NOBOX) & 94 & $\mathrm{BD}$ & $\mathrm{BD}$ & 1153 \\
\hline Inhibin alpha (INHA) & 3822 & 2033 & 33 & 21660 \\
\hline Inhibin beta $\mathrm{b}$ (INHBB) & 1471 & 387 & $\mathrm{BD}$ & 8785 \\
\hline Insulin like growth factor binding protein 1 (IGFBP1) & 582 & 257 & $\mathrm{BD}$ & 5089 \\
\hline Insulin like growth factor binding protein 2A (IGFBP2A) & 176 & 108 & $\mathrm{BD}$ & 1287 \\
\hline Insulin like growth factor binding protein 3 (IGFBP3) & 120 & 69 & $\mathrm{BD}$ & 1184 \\
\hline Insulin like growth factor binding protein 5 (IGFBP5) & 4877 & 392 & $\mathrm{BD}$ & 34386 \\
\hline Luteinizing hormone receptor (LHR) & 266 & 195 & $\mathrm{BD}$ & 2431 \\
\hline Nanos & 161 & 58 & $\mathrm{BD}$ & 2266 \\
\hline Nuclear receptor subfamily 0 group B member 1 (NR0B1) & 183 & 136 & $\mathrm{BD}$ & 1230 \\
\hline Relaxin receptor 2 (RXFP2) & 334 & 253 & $\mathrm{BD}$ & 1588 \\
\hline SRY-box 7 (SOX7) & 191 & 117 & $\mathrm{BD}$ & 1672 \\
\hline Sperm flagellar protein 1 (SPEF1) & 208 & 103 & $\mathrm{BD}$ & 2431 \\
\hline Sperm flagellar protein 2 (SPEF2) & 96 & 47 & $\mathrm{BD}$ & 1021 \\
\hline Sperm surface protein (SP17) & 143 & 82 & $\mathrm{BD}$ & 903 \\
\hline SRY-box 9b (SOX9b) & 433 & 196 & $\mathrm{BD}$ & 4890 \\
\hline Steroidogenic Acute Regulatory Protein (STAR) & 524 & 344 & $\mathrm{BD}$ & 2384 \\
\hline Synaptonemal complex protein 1 (SYCP1) & 170 & 86 & $\mathrm{BD}$ & 1963 \\
\hline Uncharacterized protein 1 & 203 & 58 & $\mathrm{BD}$ & 4623 \\
\hline Uncharacterized protein 2 & 259 & 146 & $\mathrm{BD}$ & 1909 \\
\hline Vitellogenin (VTG) & 232 & 54 & $\mathrm{BD}$ & 8166 \\
\hline Vitellogenin C (VTG C) & 182 & 48 & $\mathrm{BD}$ & 2269 \\
\hline Wnt family member $5 b$ (WNT5b) & 121 & 32 & $\mathrm{BD}$ & 1986 \\
\hline Zygote arrest protein 1 (ZAR1) & 76 & $\mathrm{BD}$ & $\mathrm{BD}$ & 1082 \\
\hline Zona pellucida 3 (ZP3) & 190 & 57 & BD & 3678 \\
\hline
\end{tabular}




\begin{tabular}{ccccc} 
Zona pellucida 3iX1 (ZP3iX1) & 109 & 32 & BD & 1428 \\
Zona pellucida 4 (ZP4) & 5823 & 114 & BD & 39825 \\
Zona pellucida AX (ZPAX) & 2389 & 314 & BD & 14264 \\
\hline
\end{tabular}

The average, median, min, and max for each gene in smallmouth bass with testicular oocytes $(\mathrm{n}=143)$ analyzed with the Nanostring $\mathrm{nCounter}{ }^{\circledR}$ for transcript abundance analysis. Asterisk $\left(^{*}\right)$ indicates a housekeeping gene. 
Table 5. Statistics of each of the 40 genes from smallmouth bass without testicular oocytes.

\begin{tabular}{|c|c|c|c|c|}
\hline Gene & Mean & Median & Min & Max \\
\hline 17-B Hydroxysteroid Dehydrogenase (HSD17B) & 952 & 834 & 187 & 3568 \\
\hline 3 beta-hydroxysteroid dehydrogenase (HSD3B) & 2832 & 2559 & 935 & 5171 \\
\hline 40 S ribosomal protein S18 (RPS18)* & 30774 & 25687 & 7502 & 76336 \\
\hline P43 5S RNA-binding protein (42Sp43) & 46 & $\mathrm{BD}$ & $\mathrm{BD}$ & 269 \\
\hline $\mathrm{B}-\operatorname{actin}(\mathrm{ACTB}) *$ & 45553 & 46698 & 16720 & 85418 \\
\hline Cytochrome P450 11B (CYP11B) & 111 & 66 & $\mathrm{BD}$ & 395 \\
\hline Aromatase (CYP19A1A) & 114 & 127 & $\mathrm{BD}$ & 285 \\
\hline Dehydrogenase reductase SDR family member 11 (DHRS11) & 2783 & 3219 & 57 & 7388 \\
\hline Doublesex and mab-3 related transcription factor 1 (DMRT1) & 3170 & 319 & 126 & 14775 \\
\hline Doublesex and mab-3 related transcription factor 2 (DMRT2) & 220 & 78 & $\mathrm{BD}$ & 763 \\
\hline Doublesex and mab-3 related transcription factor 3 (DMRT3) & 123 & 119 & 30 & 249 \\
\hline Eukaryotic translation initiation factor 3D $(\text { EIF3D })^{*}$ & 2078 & 202 & 46 & 11303 \\
\hline Follistatin (FST) & 1669 & 250 & BD & 7074 \\
\hline Follistatin 3 (FST3) & 357 & 195 & $\mathrm{BD}$ & 2563 \\
\hline Gonadotropin releasing hormone receptor (GnRHR) & 136 & 50 & BD & 764 \\
\hline Homeobox protein (NOBOX) & $\mathrm{BD}$ & $\mathrm{BD}$ & BD & 183 \\
\hline Inhibin alpha (INHA) & 3897 & 209 & 27 & 27232 \\
\hline Inhibin beta $\mathrm{b}$ (INHBB) & 1631 & 1671 & 112 & 3658 \\
\hline Insulin like growth factor binding protein 1 (IGFBP1) & 274 & 211 & $\mathrm{BD}$ & 901 \\
\hline Insulin like growth factor binding protein $2 \mathrm{~A}$ (IGFBP2A) & 124 & 96 & $\mathrm{BD}$ & 587 \\
\hline Insulin like growth factor binding protein 3 (IGFBP3) & 49 & 33 & $\mathrm{BD}$ & 234 \\
\hline Insulin like growth factor binding protein 5 (IGFBP5) & 7059 & 6187 & 51 & 28453 \\
\hline Luteinizing hormone receptor (LHR) & 259 & 221 & 76 & 692 \\
\hline Nanos & 126 & 84 & $\mathrm{BD}$ & 557 \\
\hline Nuclear receptor subfamily 0 group B member 1 (NR0B1) & 131 & 121 & 44 & 345 \\
\hline Relaxin receptor 2 (RXFP2) & 282 & 118 & $\mathrm{BD}$ & 1321 \\
\hline SRY-box 7 (SOX7) & 167 & 139 & 47 & 483 \\
\hline Sperm flagellar protein 1 (SPEF1) & 213 & 163 & $\mathrm{BD}$ & 970 \\
\hline Sperm flagellar protein 2 (SPEF2) & 60 & 32 & $\mathrm{BD}$ & 263 \\
\hline Sperm surface protein (SP17) & 116 & 99 & $\mathrm{BD}$ & 418 \\
\hline SRY-box 9b (SOX9b) & 336 & 310 & 63 & 676 \\
\hline Steroidogenic Acute Regulatory Protein (STAR) & 364 & 240 & $\mathrm{BD}$ & 1756 \\
\hline Synaptonemal complex protein 1 (SYCP1) & 241 & 97 & $\mathrm{BD}$ & 1817 \\
\hline Uncharacterized protein 1 & 41 & $\mathrm{BD}$ & $\mathrm{BD}$ & 200 \\
\hline Uncharacterized protein 2 & 176 & 65 & $\mathrm{BD}$ & 1059 \\
\hline Vitellogenin (VTG) & $\mathrm{BD}$ & $\mathrm{BD}$ & $\mathrm{BD}$ & 160 \\
\hline Vitellogenin C (VTG C) & 37 & $\mathrm{BD}$ & $\mathrm{BD}$ & 241 \\
\hline Wnt family member $5 b$ (WNT5b) & 38 & $\mathrm{BD}$ & $\mathrm{BD}$ & 276 \\
\hline Zygote arrest protein 1 (ZAR1) & BD & BD & BD & 150 \\
\hline
\end{tabular}


BD 220

The average, median, min, and max for each gene in smallmouth bass without testicular oocytes $(n=33)$ analyzed with the Nanostring nCounter® for transcript abundance analysis. Asterisk $(*)$ indicates a housekeeping gene. 
Table 6. Table of transcripts correlated with intersex.

\begin{tabular}{|c|c|c|}
\hline Gene & P-value & Rho \\
\hline $42 \operatorname{Sp} 43 *$ & $<0.001$ & 0.484 \\
\hline ZP3* & $<0.001$ & 0.478 \\
\hline UP1* & $<0.001$ & 0.457 \\
\hline VTG* & $<0.001$ & 0.454 \\
\hline NOBOX* & $<0.001$ & 0.420 \\
\hline CYP P450 11B & $<0.001$ & 0.392 \\
\hline DMRT1 & $<0.001$ & 0.386 \\
\hline FST3* & $<0.001$ & 0.390 \\
\hline IGFBP-3* & $<0.001$ & 0.392 \\
\hline ZP3iX1* & $<0.001$ & 0.390 \\
\hline DMRT2 & $<0.001$ & 0.366 \\
\hline INHA & $<0.001$ & 0.370 \\
\hline GnRHR & $<0.001$ & 0.346 \\
\hline VTG C* & $<0.001$ & 0.349 \\
\hline STAR & $<0.001$ & 0.341 \\
\hline FST & $<0.001$ & 0.314 \\
\hline RXFP2 & $<0.001$ & 0.285 \\
\hline SPEF2 & 0.002 & 0.233 \\
\hline ZAR1* & 0.009 & 0.197 \\
\hline WNT5B* & 0.034 & 0.161 \\
\hline LHR & 0.041 & -0.155 \\
\hline SP17 & 0.013 & -0.187 \\
\hline ZPAX & 0.006 & -0.206 \\
\hline CYP19A1A & 0.001 & -0.240 \\
\hline SOX9b & 0.001 & -0.258 \\
\hline ZP4 & $<0.001$ & -0.262 \\
\hline SPEF1 & $<0.001$ & -0.272 \\
\hline DHRS11 & $<0.001$ & -0.319 \\
\hline INHBB & $<0.001$ & -0.321 \\
\hline IGFBP-5* & $<0.001$ & -0.316 \\
\hline
\end{tabular}

Spearman's Rank Correlations of genes significantly correlated $(P$-value $<0.05)$ with testicular oocyte severity in male smallmouth bass from the Susquehanna and Potomac River drainages and Lake Erie drainage. Asterisk (*) indicates genes that were also significantly associated with the prevalence of testicular oocytes. 